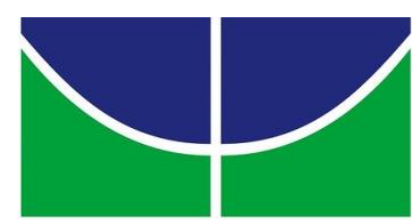

UNIVERSIDADE DE BRASÍLIA

FACULDADE DE COMUNICAÇÃO

PROGRAMA DE PÓS-GRADUAÇÃO EM COMUNICAÇÃO

\title{
DIANTE DA REALIDADE \\ NARRATIVAS DO BRASIL ENTRE 1969 E 1973
}

Leylianne Alves Vieira

Dissertação apresentada ao Programa de PósGraduação em Comunicação da Universidade de Brasília/UnB como parte dos requisitos para a obtenção do título de Mestre.

Brasília, dezembro de 2015 


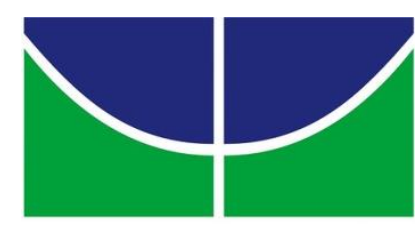

\author{
UNIVERSIDADE DE BRASÍLIA \\ FACULDADE DE COMUNICAÇÃO \\ PROGRAMA DE PÓS-GRADUAÇÃO EM COMUNICAÇÃO
}

\title{
DISSERTAÇÃO DE MESTRADO
}

\author{
Diante da Realidade \\ Narrativas do Brasil entre 1969 e 1973
}

Autor: Leylianne Alves Vieira

Orientadora: Professora Doutora Celia Maria dos Santos Ladeira Mota

Profa. Doutora Celia Maria dos Santos Ladeira Mota (UnB)

Prof. Doutor Fernando Antonio Resende (UFF)

Prof. Doutor Sergio Dayrell Porto (UnB)

Profa. Doutora Maria Jandyra Cavalcanti Cunha (UnB) 
Ficha catalográfica elaborada automaticamente, com os dados fornecidos pelo(a) autor(a)

Vieira, Leylianne Alves

Diante da Realidade: narrativas do Brasil entre 1969 e 1973 / Leylianne Alves Vieira; orientador Celia Maria dos Santos Ladeira Mota. -- Brasília, 2015 .

$222 \mathrm{p}$.

Dissertação (Mestrado - Mestrado em Comunicação) Universidade de Brasília, 2015.

1. narrativa. 2. personagem. 3. representação. 4 . revista Realidade. 5. ditadura militar. I. Mota, Celia Maria dos Santos Ladeira, orient. II. Título. 
A todos aqueles que fizeram da realidade, a REALIDADE. 


\section{AGRADECIMENTOS}

À professora Dra. Célia Maria Ladeira Mota, pela inestimável orientação;

Aos colegas e professores do Programa de Pós-Graduação em Comunicação da Universidade de Brasília, pelos momentos de profícuas discussões;

À professora Dra. Thaïs de Mendonça Jorge, por possibilitar, acompanhar e orientar minha primeira experiência com docência em Comunicação;

Ao professor Dr. Marcelo Eduardo Leite, por me apresentar a beleza que há na pesquisa e na Realidade;

A Aletheia, Antônio, Bruno, Brenda, Darliane, Fernando, Naiara e Vinícius, companheiros de caminhada, pelos estímulos à reflexão;

Aos amigos queridos, que entendem os momentos de distanciamento que a pesquisa nos exige;

À Coordenação de Aperfeiçoamento de Pessoal de Nível Superior (Capes), pelo apoio ao desenvolvimento da pesquisa;

A minha família, pelo suporte e carinho, sentidos a quilômetros de distância. 
Foi um sonho tão forte que acreditei nele por minutos como uma realidade.

Clarice Lispector 


\section{RESUMO}

A revista Realidade foi lançada no ano de 1966, durante o regime militar brasileiro. A publicação se intitulava uma revista de reportagens, o que fez com que seus repórteres mergulhassem em um Brasil distante e desconhecido, em busca de personagens que apresentassem o país aos brasileiros. A segunda fase da revista (1969-1973), período sobre o qual trata esta pesquisa, se dá após a promulgação do Ato Institucional $\mathrm{N}^{0} 5$ (13 de dezembro de 1968), uma das principais expressões do autoritarismo daquele governo, e coincide com o período do chamado Milagre Econômico. Em um país em desenvolvimento, Realidade narrava em suas reportagens a vida de pessoas que viviam na miséria que assolava diversos pontos do país. Nesta pesquisa, detemo-nos sobre cinco destas personagens, objetivando analisar as representações feitas pelos jornalistas. Buscamos compreender como se dá, nas reportagens de Realidade, os recortes narrativos sobre os brasileiros esquecidos pelo Milagre Econômico. As reportagens Devagar com o boi, O canavial esmaga o homem, Povo Caranguejo, Quem é o homem no fundo do poço? e 30 dias na ilusão do garimpo foram escolhidas no âmbito da pesquisa enquanto narrativas que expressam a experiência e a vivência dos repórteres naquele período histórico. Analisamos os textos a partir dos pressupostos teóricos e metodológicos da Análise Crítica da Narrativa (MOTTA, 2013) e dos Estudos Culturais, dando especial atenção à construção das personagens, ao papel do narrador e, sobretudo, aos significados que emergiram da metanarrativa que envolveu tais reportagens. As estórias apresentadas por Realidade diferiam significativamente daquela imagem de país em pleno desenvolvimento, conforme a publicidade realizada pelo governo frente ao crescimento econômico. O brasileiro, enquanto personagem das narrativas, apresenta-nos um país no qual as comunidades vivem na lama, na miséria. São retratos de pessoas exploradas, doentes, sobrevivendo em meio aos inúmeros problemas que enfrentam. Deparamo-nos, portanto, com narrativas que dialogam a dupla experiência vivida pelos repórteres: ao mesmo tempo em que ali explicitam a cotidianidade de brasileiros desconhecidos, também deixam transparecer problemáticas que envolvem a conjuntura do regime militar.

Palavras-chave: narrativa; personagem; representação; revista Realidade; ditadura militar 


\begin{abstract}
Realidade is a magazine which was launched in 1966, during the Brazilian military regime. The publication was entitled as a magazine of stories, written by reporters dipped in a distant and unknown Brazil in search of characters to present the country to the Brazilians. The second phase of the magazine (1969-1973), period over which the research was conducted, occurred after the promulgation of Institutional Act No. 5 (December 13, 1968), one of the main expressions of government authoritarianism, corresponding to the period of the so-called Economic Miracle. In a developing country like Brazil in those years, Realidade told stories about people living in the poverty that plagued many regions. In this research, we reflected on five of those characters, aiming to analyze the representations made by journalists. We seek to understand, in the Realidade reports, how were the narrative passages about forgotten Brazilian people during the Economic Miracle. The reports were: Slowly with the ox, The cane field crushes the man, Crab People, Who is the man in the deep well? and Thirty days in the gold mining illusion. Those texts were chosen as narratives that expressed the experiences and the sufferings of the reporters at that historical period. We analyze the texts from the theoretical and methodological assumptions of Critical Analysis of Narrative (MOTTA, 2013) and Cultural Studies, with special attention to the construction of the characters, to the role of narrators and, above all, to the meanings that emerged from the metanarrative involving such reports. The stories presented by Realidade differed significantly from the image of a developing country as proposed by the advertising carried out by the military government. The Brazilian people, as a character of the narratives, presented us a country where communities were living in the mud, in misery. They are portraits of exploited and ill people surviving amid the numerous problems they faced. On the other side, we analyzed narratives that show us the dialogue between the experiences lived by the reporters while they were trying to explain the daily life of unknown Brazilian persons, allowing us to look through the problems involving the situation of the military regime.
\end{abstract}

Key-words: narrative; character; representation; Realidade magazine; military regime 


\section{APRESENTAÇÃO}

Realidade foi lançada no ano de 1966, mais precisamente no mês de abril. A publicação se definia enquanto uma revista de reportagens. Deixou as bancas em março de 1976, após o $120^{\circ}$ número. Neste meio tempo, construiu uma história junto à sociedade e ao jornalismo não só brasileiros, mas também mundiais, o que a faz ser lembrada até hoje nos cursos de Comunicação.

A famosa publicação da Editora Abril não circulou fortemente na região Nordeste, mas, mesmo assim, quarenta e quatro anos após seu lançamento, em 2010, chegam às minhas mãos alguns exemplares da tão famosa revista. Aquele momento de contato, de observação, de deleite frente àquela revista de dimensões extravagantes, repleta de textos e fotografias, tratando de temas diversificados, foi o início de um caminho que vem sendo traçado até hoje.

Lendo Honoré de Balzac, Truman Capote, Tom Wolfe e as reportagens de Realidade, deparei-me com formas de jornalismo que não se prendem à famigerada objetividade, que mergulham nas mais diversas problemáticas, que buscam no cotidiano o material essencial para narrativas que tocam o leitor, que dialogam com o seu entorno e as suas relações interpessoais.

Durante a graduação em Jornalismo, realizada na Universidade Federal do Ceará, desenvolvi minha monografia, sob a orientação do professor Dr. Marcelo Eduardo Leite, tendo como objeto de estudo os três primeiros anos de Realidade, a chamada primeira fase da revista, na qual esteve trabalhando a equipe fundadora daquela, sob a coordenação do jornalista Paulo Patarra. Esses jornalistas, fotógrafos e editores definiram os parâmetros pelos quais a publicação se deveria guiar.

Debrucei-me sobre os personagens que fizeram daquela publicação uma referência no contexto do jornalismo nacional: os jangadeiros do Ceará, os garimpeiros de Mato Grosso, os magarefes da Bahia, os salineiros do Rio Grande do Norte, as prostitutas de São Paulo, enfim, 
deparei-me com um país revelado por meio de seus personagens, que ganham voz e traduzem para os leitores parcelas da cotidianidade do país.

Ao longo deste percurso, tive a oportunidade, ainda, de participar do projeto Realidade: o fotojornalismo (autoral) de uma revista, também sob a orientação do professor Dr. Marcelo Eduardo Leite. Nesta ocasião, desenvolvemos o projeto buscando, nas narrativas fotográficas da revista, indícios e exemplos de como os repórteres fotográficos daquela publicação dispunham de certa liberdade diferenciada dos demais veículos da época para o desenvolvimento de seus trabalhos.

Neste caminho, porém, além de darmos relevo aos depoimentos dos fotógrafos que participaram da publicação e às reportagens, buscamos ainda o testemunho de repórteres, editores e mesmo de outras pessoas que conviviam com aquela equipe. Com este material em mãos, desenvolvemos uma página na internet, um catálogo e uma exposição, todos contendo trechos das reportagens digitalizadas e das entrevistas produzidas.

Ao longo das leituras, aproximações e desenvolvimento de trabalhos, vislumbrei na chamada segunda fase da revista, que vai de janeiro de 1969 até setembro de 1973, uma nova possibilidade de estudo. Este período se dá após a promulgação do Ato Institucional $\mathrm{N}^{\mathrm{o}} 5$, em dezembro de 1968. Apesar da mudança de equipe que ocorreu, Realidade continua nos apresentando personagens diversos do país: o pescador de tubarão do Rio Grande do Norte, os caçadores de caranguejo da Paraíba ou o garimpeiro em Goiás, entre tantos outros.

Em um período conturbado da história do Brasil, no qual se propagandeava que a economia estava em franco desenvolvimento, vivendo mesmo um Milagre, Realidade nos apresenta homens que lutam para sobreviver ganhando um salário mínimo, crianças que morrem de doenças que poderiam ser tratadas facilmente, pessoas que não sabem ler por conta da ausência de escolas. Foi a partir destas observações que nasceu a inquietação que ora se traduz nesta Dissertação de Mestrado. 


\section{SUMÁRIO}

INTRODUÇÃO

\section{CAPÍTULO I}

AS REVISTAS ILUSTRADAS NO BRASIL: A REVISTA REALIDADE

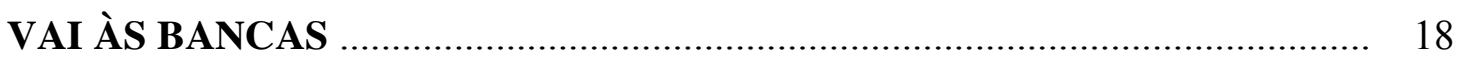

1.1 Uma sociedade em transformação ................................................................ 20

1.2 Um milagre à vista: economia em alta? ....................................................... 21

1.3 Revista Realidade, uma revista de reportagens ............................................. 23

1.3.1 Realidade: um sonho possivel ............................................................. 25

1.3.2 Uma publicação de três faces ............................................................... 32

CAPÍTULO II

ANÁliSE DA NARRATIVA: UM PROCEDIMENTO PARA INVESTIGAR O TEXTO JORNALÍSTICO ........................................................................ 40

2.1 Narrativas: formas de retratar o mundo ....................................................... 42

2.2 Como analisar narrativas? Da Análise Estrutural à Crítica ........................... 47

2.3 A narrativa jornalística e o efeito de real ..................................................... 51

\section{CAPÍTULO III}

REALIDADE E NARRATIVAS: APORTES METODOLÓGICOS ................... 59

3.1 As três etapas de observação: os planos de análise da narrativa ..................... 60

3.2 Elementos construtores do texto: entre o fictício e o factual ............................ 63

3.3 A personagem enquanto construção narrativa .................................................. 66

3.4 O narrador enquanto condutor da narrativa: a presença do repórter no texto 70

3.5 A metanarrativa e a criação de sentidos: o mergulho na narrativa ................ 72

3.6 Realidade em análise: percurso metodológico ............................................. 72

\section{CAPÍTULO IV}

NARRATIVA I: DEVAGAR COM O BOI ..................................................... 78

4.1 Abertura: fotografias e representação ............................................................. 79

4.2 O início da jornada, a relação entre os peões ................................................. 82

4.3 O peão e a boiada: a relação entre as personagens ........................................ 83 
4.4 O trabalho rumo às invernadas do sul

\section{CAPÍTULO V}

NARRATIVA II: O CANAVIAL ESMAGA O HOMEM

5.1 A luta entre o canavial e o homem: duas personagens contraditórias .............. 109

5.2 O embate se intensifica: a busca pela vingança .............................................. 116

\section{CAPÍTULO VI}

\section{NARRATIVA III: POVO CARANGUEJO}

6.1 Uma narrativa, duas personagens: o caranguejo e o homem como protagonistas

6.2 O embate entre as personagens: a luta pela vida

6.3 O dia seguinte: o valor associado ao caranguejo e ao futuro

\section{CAPÍTULO VII}

NARRATIVA IV: QUEM É O HOMEM NO FUNDO DO POÇO?

7.1 O diálogo entre páginas: a apresentação da personagem 151

7.2 Pode entrar: o narrador apresenta o ambiente 155

7.3 O papel do narrador: entre dados e questionamentos 159

7.4 Uma família narrada: a busca pelo sonho

\section{CAPÍTULO VIII}

\section{NARRATIVA V: 30 DIAS NA ILUSÃO DO GARIMPO}

8.1 Entre o trabalho e a ilusão: vida e morte no garimpo 174

8.2 A chegada ao garimpo: construindo uma personagem 181

8.3 A narrativa da morte e seus efeitos sobre o repórter-personagem 187

8.4 O garimpeiro ganha força: conflito interior entre personagens 198 


\section{INTRODUÇÃO}

Realidade, publicação mensal lançada no ano de 1966 pela Editora Abril, propunha-se a ser uma revista de reportagens, que mergulhasse na cotidianidade do país, buscando nos mais variados personagens e espaços formas de expressar um Brasil ainda não apresentado aos brasileiros. Os textos ali publicados se dispunham a compor personagens, cenas e ambientes por meio de estratégias linguísticas mais próximas à subjetividade da Literatura que à objetividade impelida, de certa maneira, ao Jornalismo. Esta busca da publicação pela ênfase nas reportagens nos leva a outorgar maior atenção a este tipo de texto.

A revista tem sua história dividida em três estratos: o primeiro, correspondente à equipe inicial de repórteres e editores, está situado entre os meses de abril de 1966 e dezembro de 1968; o segundo, caracterizado pela mudança no quadro de funcionários, iria de janeiro de 1969 a setembro de 1973; ao passo que a última fase está situada entre outubro de 1973 e março de 1976 e é assinalada pela mudança no formato da revista e em sua proposta editorial. Esta divisão foi estabelecida no âmbito da academia, mas é aceita por uma parcela dos jornalistas que fizeram parte da revista.

A primeira fase da publicação foi amplamente estudada pelas áreas da Linguística, História e Comunicação. As personagens das reportagens de Realidade nesse início eram, em geral, pessoas anônimas, com as quais os leitores poderiam se identificar. Além disso, eram atores sociais de cenários que poderiam ser facilmente apreendidos pelos leitores, tanto por meio da cotidianidade a qual eles poderiam estar expostos quanto pela ampla descrição textual e imagética. Em resumo, a revista se preocupava, segundo seu projeto editorial, o qual se consolidou ao logo de seus primeiros anos de existência, em publicar textos que levassem os leitores a uma identificação com personagens e ambientes físicos.

Já o segundo período, até o momento, não deu origem a um estudo voltado exclusivamente para ele. Em levantamento realizado em coleção particular da publicação, pude perceber que as personagens apresentadas na segunda fase têm características comuns 
àquelas do primeiro momento. Estes actantes ganham as páginas de Realidade e são caracterizados de forma a aproximá-los dos leitores por meio de textos e fotografias, frutos da vivência dos repórteres junto à cotidianidade dos ambientes que os rodeiam.

O período sobre o qual nos debruçamos aqui, esta chamada segunda fase, dá-se após a promulgação do Ato Institucional $\mathrm{N}^{\mathrm{o}} 5^{1}$, um dos responsáveis pela institucionalização da censura aos meios de comunicação durante a Ditadura Militar brasileira. Esta fase, durante o governo do general Artur da Costa e Silva, é caracterizada pela repressão oposicionista e é quando o governo assume a alcunha de Anos de Chumbo.

No entanto, a imagem repressiva do governo era compensada pela situação econômica favorável: o país vivia sob a égide do expressivo crescimento que ficou conhecido como Milagre Econômico. O crescimento, basicamente inesperado pelo regime, passa a ser utilizado como ferramenta de combate à oposição, insatisfeita com o governo. Porém, o "milagre" não estava posto de maneira semelhante para todos os cidadãos, de forma que a má distribuição de renda vivenciada hoje no país pode ser tida como um dos legados daquele período.

Propomo-nos, então, a realizar uma incursão por entre algumas das reportagens publicadas, buscando identificar nas personagens apresentados por tais narrativas, elementos que nos permitam perceber a forma como as mesmas foram tratadas naquele veículo. Em se tratando de textos literários, destacamos que há quem diga que a Literatura é o que nos faz humanos $^{2}$. Mas não apenas os textos de ficção nos aproximam do que chamamos de realidade e das construções sociais que estabelecemos. O homem é um ser essencialmente narrativo. Constrói a sua imagem e o mundo ao redor a partir de narrativas. Quer de forma fictícia, quer fática, o narrar está presente no nosso cotidiano: conversas, livros, jornais, estes elementos nos contam versões do mundo e contribuem para a construção de nossa identidade, individual ou coletiva.

Assim, vislumbramos na utilização da Teoria da Narrativa, a possibilidade da busca por identificar nos textos elementos que nos ajudem a analisar narrativas jornalísticas: textos fáticos construídos a partir de componentes semelhantes aos utilizados em textos literários. Narrador, tempo e personagem, por exemplo, podem ser identificados em ambos os casos.

\footnotetext{
${ }^{1} \mathrm{O}$ Ato Institucional $\mathrm{n}^{\mathrm{o}} 5$ foi decretado num momento no qual os militares da linha-dura exerceram maior poder; instituía a censura a correspondências, à imprensa e às telecomunicações (ALMEIDA, 2009, p. 85).

${ }^{2}$ Opinião do filósofo e linguista Tzvetan Todorov, um dos principais nomes ligados à gênese do estudo de narrativas (GARCIA, 2012).
} 
Para além da composição do texto, as personagens, em especial, permitem ao leitor identificar-se com as realidades retratadas nas reportagens.

Destacamos que aqui estamos utilizando o conceito de narrativa segundo a definição de Motta (2013, p. 38), para o qual “a enunciação narrativa é uma atitude intencional e argumentativa, portanto: toda narrativa se origina em uma estratégia enunciativa", destacando a intencionalidade do texto e do autor em construir uma determinada imagem ou informação. Nos casos específicos do Jornalismo e da História, estamos lidando com a construção do real, de forma que o mesmo nada mais é que "[...] o efeito produzido pelo discurso, compactuado pelo narrador e o receptor" (MOTTA, 2013, p. 39-40, grifo do autor).

Para tanto, temos de considerar as narrativas enquanto representações sociais e formas de se forjar indivíduos e nações, conforme aponta a Teoria da Narrativa (MOTTA, 2013, p. 34). Observando-as a partir de tais premissas, entendemos que as reportagens publicadas por Realidade contribuíram, em parte, para a construção da identidade nacional, bem como construíram certo imaginário acerca de lugares pouco visitados por outros veículos de comunicação da época.

Assim, almejamos apresentar e compreender as estratégias narrativas utilizadas naqueles textos, dando vistas ao seguinte problema de pesquisa: como as narrativas da revista Realidade representaram os brasileiros esquecidos pelo Milagre Econômico, entre 1969 e 1973?

No âmbito deste trabalho, consideramos as reportagens selecionadas narrativas fáticas, ou seja, narrativas jornalísticas que relatam acontecimentos dos campos social, econômico, político e/ou cultural. Tendo em vista o caráter das reportagens de Realidade, entendemos, conforme Motta, que

[...] há narrativas fáticas que dramatizam seus enredos e sua retórica, e em consequência produzem subjetividades e catarses próximas à arte, como em algumas reportagens jornalísticas, biografias e documentários cinematográficos. Muitas narrativas transitam, por natureza ou por vontade de seus narradores, no pantanoso terreno entre a objetividade e a subjetividade, a fantasia e a realidade objetiva, espaço de eterna querela filosófica (MOTTA, 2013, p. 14).

Tais textos apontam características subjetivas das personagens, próprias daqueles que ganham espaço no texto, escrito ou imagético. Falar em subjetividade é caracterizar as diferentes personagens que são objetos das reportagens. Podem ser pescadores, professores, analfabetos, garimpeiros, índios, entre tantos outros. O que estas personagens têm em 
comum? São representações sociais de um tipo de brasileiro que em geral não atrai a atenção dos jornalistas e da mídia. É preciso lembrar que estamos nos referindo a uma época do Brasil marcada pelo regime militar, o qual impôs rigorosa censura aos meios de comunicação.

No início, a maior parte dos veículos de expressão nacional apoiou o golpe que deu origem à ditadura: Correio da Manhã, Jornal do Brasil, O Globo, O Estado de S. Paulo e os Diários Associados, todos estes estavam engajados politicamente e defendiam a conspiração (ALMEIDA, 2009, p. 82). No entanto,

O que vimos foi o estabelecimento de um governo autoritário, com cassações de mandatos parlamentares, expurgos de sindicalistas e prisões arbitrárias, que teve seu apogeu com a decretação do AI-5. Foi nesse momento que a postura da imprensa brasileira mudou rapidamente: de defensora do golpe a contestadora (ALMEIDA, 2009, p. 83).

A censura prévia foi exercida tanto pelos oficiais do Exército quanto pela Polícia Federal. Como forma de denunciar os trechos ou textos censurados, alguns periódicos usaram de artifício que dessem indícios aos leitores do que estava acontecendo nos bastidores da imprensa: O Estado de S. Paulo e o Jornal da Tarde publicavam receitas culinárias ou versos de Os lusíadas, de Camões; já a revista Veja publicava anúncios publicitários da própria Editora Abril, com a arvorezinha da empresa, ou imagens de anjinhos e diabinhos (ALMEIDA, 2009).

Apesar da censura, ou por causa dela, Realidade, se centrou na possibilidade de reportagens que tivessem como personagens os brasileiros esquecidos pelo governo e pela mídia. Estes brasileiros, cujas profissões os colocam na base da pirâmide social, tornaram-se a principal marca da revista, em suas duas primeiras fases.

Nas décadas de 1960 e 1970 o Brasil ainda dava lugar a diversos 'brasis', em parte desconhecidos. Os brasileiros só poderiam construir um conhecimento mais próximo da completude que representava aquela nação, portanto, caso tivessem acesso a narrativas que compartilhassem a multiplicidade cultural do país. A narrativa midiática é uma das possibilidades de acesso a tais narrativas. Realidade, enquanto revista de reportagens, produto de um determinado momento histórico e cultural, buscava mostrar o Brasil aos brasileiros, tendo como um de seus objetivos prestar contributo à construção da identidade brasileira: dava a seus leitores a possibilidade de acessarem narrativas outras, diversas àquelas já compartilhadas por eles. Narrava um Brasil ainda desconhecido, mostrava aos leitores que 
havia outras possibilidades de 'ser brasileiro', bem distante, grifamos, daquele Brasil em pleno desenvolvimento econômico.

Há, portanto, uma conexão entre o Brasil narrado jornalisticamente e aquele que é compartilhado pelos brasileiros. A narrativa do mundo torna possível, por parte do leitor, o conhecimento de aspectos não vivenciados por ambos os interlocutores. Assim, congregandose a narrativa de Realidade à construção do brasileiro enquanto personagem que compõe a narrativa do país,

Estas narrativas simbólicas sobre o Brasil levam em conta o conceito de nação enquanto uma comunidade imaginada, sobre a qual se constroem estórias, imagens, signos e rituais nacionais que simbolizam ou representam as experiências partilhadas. São narrativas que conectam nossas vidas com um destino nacional, criando um sentido de pertencimento (MOTA; ALMEIDA, 2015, p. 45).

Entendemos que as narrativas de Realidade dão aos leitores elementos que contribuem para o delineamento de uma personagem com a qual ele se identifique: o brasileiro das décadas de 1960 e 1970. Trazendo para suas páginas narrativas que reconstroem ambientes distantes aos leitores daquele momento histórico e o fazendo por meio de personagens emblemáticos e distantes, a revista contribui para conectar a narrativa daquele Brasil com a que possuímos hoje. Mergulhando nas narrativas aqui selecionadas, buscamos elementos que nos apontem as formas narrativas utilizadas pelos narradores-jornalistas daquele periódico e, numa leitura posterior, nos dão indícios da narrativa que está por traz da construção de cada uma das personagens. Neste momento, iniciamos nosso mergulho rumo à significação construída nas páginas de Realidade.

No primeiro capítulo deste trabalho, apresentamos o contexto histórico e social no qual Realidade foi publicada, bem como apontamos as principais características daquela revista de reportagens que surgiu no Brasil em 1966. Editores, repórteres de texto e fotográficos e pesquisadores nos apresentam a publicação, desde seus primeiros números até a mudança editorial que culminou com o fim da revista. Focalizamos, no entanto, nas perspectivas de trabalho da equipe em meio à repressão imposta pela ditadura militar após a publicação do Ato Institucional $\mathrm{N}^{\mathrm{0}} 5$.

O segundo capítulo é dedicado à discussão acerca da Análise Crítica da Narrativa, aporte teórico que utilizamos na pesquisa. Neste sentido, trabalhamos com a narrativa como uma das componentes da construção da identidade e da cultura de um grupo, o que nos 
remete, por conseguinte, aos Estudos Culturais britânicos. Já no terceiro capítulo, abordamos os principais conceitos utilizados no trabalho - personagem, narrador e metanarrativa -, a fim de apresentarmos os caminhos metodológicos que traçamos.

Por fim, os Capítulos IV, V, VI, VII e VII são dedicados às narrativas escolhidas em Realidade. Trabalhamo-las de forma independente, buscando os significados que emergem de cada uma das reportagens. Nossas personagens, assim, permitem a construção de assertivas acerca daquele momento histórico do país. Ao final, traçamos considerações acerca dos significados traçados pela revista, apresentando-nos pessoas simples, vivendo na miséria, nos mais diversos pontos do Brasil, em pleno Milagre Econômico. 
CAPÍTULO I

\section{AS REVISTAS ILUSTRADAS NO BRASIL: A REVISTA REALIDADE VAI ÀS BANCAS}

As revistas ilustradas são caracterizadas pela junção de duas formas de narrativa, a fim de apresentarem um mesmo tema: imagem e escrita se unem com a finalidade de transmitirem uma determinada informação. Tal conjugação ajuda a formular as representações de mundo que cada cidadão detém em seu imaginário. Já narrar, nos termos de Motta $(2005$, p. 07), é "[...] relatar eventos de interesse humano enunciados em um suceder temporal encaminhado a um desfecho. Implica, portanto, em narratividade, uma sucessão de estados de transformação responsável pelo sentido". Desta forma, a dupla narrativa das reportagens das revistas ilustradas tem, obrigatoriamente, que informar acerca de um assunto que tenha relevo para aquela sociedade, pertencente àquele momento histórico e cultural.

Este tipo de publicação surge no final do século XIX e se consolida no início do século XX, especialmente na Alemanha. As novas revistas se inserem numa outra dinâmica, na qual os fotógrafos tinham maior autonomia, atuando com liberdade de escolha e de criação (NEWHALL, 2006, p. 259). O grande desenvolvimento deste segmento em território alemão pode ser observado na década de 1920, onde existiam ali mais revistas ilustradas que em todo o restante do mundo.

Através da união de linguagens, o público teve acesso a uma nova forma de tratamento da informação, na qual texto e imagem se integravam. Posteriormente, com a chegada de Hitler ao poder, em 1933, e todo controle imposto sobre a imprensa, tais profissionais migram para outros países, nos quais fomentam novas publicações (NEWHALL, 2006, p. 259-260). O surgimento de $V u$ (1928), na França, Look (1937) e Life (1936), nos Estados Unidos, e Picture Post (1938), na Inglaterra, exemplificam a diversificação de títulos apresentados por este momento fundamental para o jornalismo impresso. Com relação ao potencial alcançado pelas publicações ilustradas, a Life é um importante exemplo, pois o impacto causado quando da 
cobertura da guerra do Vietnã modificou a opinião pública acerca daquele conflito (KOBRÉ, 2011, p. 447 - 448). A fotografia, neste caso a narrativa fotográfica, pode ser apreendida enquanto informação com importante papel político.

No que tange ao Brasil, a disseminação das revistas ilustradas se deu em período semelhante. Logo na primeira década do século XX houve o declínio dos folhetins e a difusão das revistas ilustradas, trazendo para os leitores títulos como Revista da Semana (1900), FonFon! (1907) e Careta (1908), entre outros (MUNTEAL; GRANDI, 2005, p. 16). No ano de 1928, é lançada a revista ilustrada Cruzeiro $^{3}$. Essa publicação contribuiu para a construção de uma representação acerca da população brasileira, especialmente entre as décadas de 1940 e 1950, porém, vale destacar que a mesma “[...] apareceria quase sempre na condição de vítima de uma situação de miséria ancestral e, ao mesmo tempo, protagonista de uma luta inglória contra condições sub-humanas de existência” (COSTA; BURGI, 2012, p. 174).

Poucos anos depois, em 1952, nasce Manchete, publicação caracterizada pelas coberturas fotográficas realizadas. A revista lançada por Adolpho Bloch fidelizou o público por meio de reportagens históricas como, por exemplo, a publicada em 1960, sobre a inauguração de Brasília (NASCIMENTO, 2002, p. 17). Segundo Munteal e Grandi, a nova publicação tinha objetivos específicos a serem atingidos, por meio das fotografias, tais como “[...] fazer com que até os analfabetos pudessem 'ler' os artigos, trazendo uma narrativa visual, independente do texto de suas reportagens" (MUNTEAL; GRANDI, 2005, p. 93), o que fazia distribuindo fotografias de forma diferenciada e publicando grandes reportagens caracterizadas pelo uso massivo de imagens para condução da notícia. Esta prática foi iniciada pela $O$ Cruzeiro, revista semanal que atingia grande público que não sabia ler e que se informava por meio das narrativas visuais, sobretudo a população rural e os moradores das pequenas cidades.

Logo em seguida, em 1966, chega às bancas Realidade, publicação, também ilustrada, sobre a qual nos debruçamos neste trabalho. Porém, antes de descrevermos suas características editorias e mesmo históricas, destacamos a importância de observamos os contextos social e cultural das décadas de 1950 e 1960, a fim de compreendermos o que discutiam e o que pretendiam aqueles jornalistas e leitores, para assim termos uma base para refletirmos sobre o conteúdo dos textos publicados na revista.

\footnotetext{
${ }^{3}$ A revista passou a se chamar $O$ Cruzeiro em junho de 1929, no no 30 (COSTA; BURGI, 2012, p. 12).
} 


\subsection{Uma sociedade em transformação}

Em meio a gama de valores semeados na década de 1950, tais como o American Way of Life e a televisão enquanto meio de comunicação e entretenimento, pode-se observar a consolidação de um modelo de sociedade urbana no Brasil. Isso se deu, mundialmente falando, em função da velocidade com a qual a informação passou a percorrer as mais variadas distâncias. No entanto, uma parte significativa dos intelectuais da época aderiu a uma leitura semelhante da realidade nacional: um país subdesenvolvido, industrialmente atrasado e culturalmente colonizado, onde a busca pelo nacional e democrático se fazia urgente (SIMONARD, 2006, p. 24).

Foi durante as décadas de 1960 e 1970 que se consolidou, também, a ditadura militar brasileira, sendo estes anos responsáveis por incontáveis acontecimentos de interesse geral e que, certamente, contribuíram para a caracterização do país que conhecemos hoje. Durante o regime, os militares lançaram mão dos chamados Atos Institucionais ${ }^{4}$ : ao longo de todo o governo foram dezessete ${ }^{5}$ Atos, sendo o último promulgado em 14 de outubro de 1969.

A década de 1960 foi permeada por diversos acontecimentos de valor histórico: o homem foi à lua (1969); houve o primeiro bem sucedido transplante de rim do Brasil (1965); aconteceram alguns dos maiores protestos de estudantes da história do país (1968); e foram inauguradas obras de grande porte (1960). O modo de pensar dos brasileiros foi-se adaptando aos novos tempos, de forma que se fazia importante a presença de veículos de comunicação que apresentassem um novo país, que trouxessem à tona discussões locais e mundiais.

Tal período é caracterizado pelo processo de busca pela afirmação nacional. A produção cultural foi peça-chave para a consolidação do ideário do que seria 'ser brasileiro'. Se retornarmos à década de 1950, veremos que já ali um grupo de jovens deu início à concepção de um cinema nacional onde se criasse uma identidade político-cultural: surgia naquele momento o Cinema Novo (SIMONARD, 2006, p. 27).

De forma semelhante, a música denunciava as mudanças políticas dessa nação em crescimento, dando especial atenção ao que decorria do regime ditatorial. Neste contexto, nasce outro movimento de afirmação nacional: a Tropicália. Não rompendo com a cultura política forjada naqueles anos (1950 e 1960), ela foi, antes, uma visão crítica do romantismo

\footnotetext{
${ }^{4}$ Normas elaboradas entre os anos de 1964 e 1969 e editadas pelos comandantes do Exército, da Marinha e da Aeronáutica ou pelo Presidente da República.

${ }^{5}$ Para mais informações acessar http://www4.planalto.gov.br/legislacao/legislacao-historica/atos-institucionais.
} 
nacionalista e do realismo nacional-popular, visando à constituição de uma identidade do povo brasileiro (RIDENDI, 2000, p. 269).

Nos primeiros anos da ditadura militar, a imprensa esboçou pouca resistência ao autoritarismo do regime, de forma que se fez possível perceber certo apoio vindo da maior parte dos veículos impressos da época ao golpe militar em 1964. O próprio "Chateaubriand apoiou o golpe militar. Tanto que, ao lado do governador de São Paulo, Ademar de Barros, organizou a 'Marcha da Família com Deus pela Liberdade' em 19 de março de 1964, prenúncio do golpe" (LAURENZA, 2008, p. 180).

Sobre o papel da imprensa no episódio político de 1964, Almeida (2009) destaca alguns veículos e suas posições em relação ao golpe:

\begin{abstract}
A maioria dos jornais de expressão nacional apoiou o golpe, como Correio da Manhã, Jornal do Brasil, O Globo, jornais dos Diários Associados e $O$ Estado de S.Paulo. Nessa época, havia uma imprensa engajada politicamente, os jornais representavam e defendiam pretensões de grupos ou partidos políticos (ALMEIDA, 2009, p. 82).
\end{abstract}

No entanto, quando tem início o período de repressão, os veículos de comunicação, em geral, passam a um caráter mais de denúncia que de apreço. Almeida (2009, p. 85) elenca os principais artifícios legais instituídos durante o Regime Militar que versam sobre a imprensa, são eles: Lei de Imprensa (Lei n $\left.{ }^{0} 5.250,09 / 02 / 1967\right)$ e Lei de Segurança Nacional (Decretolei $\left.\mathrm{n}^{0} 898,29 / 09 / 1969\right)$, além dos Atos Institucionais. A primeira teve como objetivo regular a livre manifestação do pensamento e da informação, ao passo que a segunda puniria qualquer veículo que tentasse indispor o povo e o governo, por meio de notícias falsas ou mesmo de um fato verdadeiro deturpado.

\title{
1.2 Um milagre à vista: economia em alta?
}

No início da década de 1960 o Brasil passava por um processo de crise econômica, marcada pela estagnação de um crescimento que vinha se dando desde o final da Segunda Guerra Mundial. A taxa média anual de crescimento do Produto Interno Bruto (PIB) do Brasil foi uma das maiores do mundo por quinze anos, caindo à metade entre 1963 e 1967 (EARP; PRADO, 2007, p. 209).

As mudanças internas de tal quadro têm início em 11 de abril de 1964, com a eleição do general Humberto de Alencar Castelo Branco para a Presidência da República. Octavio 
Gouvêa de Bulhões montou uma equipe econômica para o governo que já mantinha contato anteriormente entre si e que, em geral, havia trabalhado em cargos técnicos no Banco do Brasil, de forma que "a nova equipe econômica deu prioridade à luta para reverter a tendência de contínuo aumento da taxa de inflação que se vinha manifestando desde o início da década" (EARP; PRADO, 2007, p. 213).

Apesar dos esforços do governo de Castelo Branco ${ }^{6}$, a inflação não chegou às metas de $25 \%$ em 1965 e 10\% em 1966, ficando em cerca de 40\%. No entanto, de acordo com Earp e Prado (2007, p. 216), as reformas institucionais possibilitadas por este governo criaram as bases para o modelo de crescimento econômico que pode ser observado no governo seguinte, do general Artur da Costa e Silva (1967-1969).

Em 1967, Delfim Netto foi nomeado Ministro da Fazendo e Hélio Brandão, Ministro do Planejamento. No governo do general Costa e Silva, a prioridade foi dada ao aumento da participação do setor privado na economia, em detrimento da participação do setor público, numa sequência ao que vinha sendo realizado no governo de Castelo Branco. Ainda nesse governo, irromperam vários movimentos de insatisfação com a ditadura, visando à redemocratização, de forma que

\begin{abstract}
Sucederam-se rapidamente a repressão ao movimento oposicionista, com a detenção dos delegados ao Congresso da UNE, o Ato Institucional $\mathrm{n}^{\circ} 5$, novas cassações de adversários, a morte de Costa e Silva, o início da luta armada contra o regime, a posse de uma junta militar provisória e a escolha do novo presidente, o general Emílio Garrastazu Médici. O regime assumiu, então, seu formato mais autoritário, e derrotou seus adversários - para o que teve importância decisiva o então inesperado sucesso no campo econômico (EARP; PRADO, 2007, p. 221).
\end{abstract}

Diz-se que tal crescimento econômico foi inesperado porque, aparentemente, não foi percebido logo que teve início. Earp e Prado (2007, p. 222) afirmam que os intelectuais e a opinião pública viram com certa desconfiança os anúncios de crescimento alardeados pelo governo, uma vez que não eram sentidos de forma clara.

Durante o mandato do general Emílio Garrastazu Médici (1969-1974), foi dada continuidade à busca por legitimidade para o governo por meio do sucesso econômico do país, processo iniciado de forma efetiva no governo Costa e Silva. Neste momento, o

\footnotetext{
6 "As primeiras medidas do governo do general Castelo Branco (1964-67) foram: intervenção nos sindicatos e nas entidades estudantis, proibição das greves, instauração da censura, criação do SNI (Serviço Nacional de Informação), cassação de mandatos e suspensão por dez anos dos direitos políticos de parlamentares oposicionistas [...] o governo centralizou todo o poder e todas as decisões no Executivo, governando na base de atos institucionais, decretos-leis e constituição outorgada" (HABERT, 1996, p. 09).
} 
expressivo crescimento passa a ser chamado de 'Milagre Econômico Brasileiro'. Num apanhado geral da configuração do período, Habert afirma que

\begin{abstract}
O que se convencionou chamar de "milagre" tinha a sustentá-lo três pilares básicos: o aprofundamento da exploração da classe trabalhadora submetida ao arrocho salarial, às mais duras condições de trabalho e à repressão política; a ação do Estado garantindo a expansão capitalista e a consolidação do grande capital nacional e internacional; e a entrada maciça de capitais estrangeiros na forma de investimentos e de empréstimos (HABERT, 1996, p. 13-14).
\end{abstract}

Esse momento histórico coincide com a parcela mais autoritária da ditadura militar brasileira. A censura estava institucionalizada, ao mesmo tempo em que se sabia da ampla utilização da tortura aos presos políticos: o clima era de terror, situação supostamente exigida em nome da 'segurança nacional' e do combate ao comunismo (HABERT, 1996, p. 07).

Vale destacar, no entanto, que tal processo implicou em algo mais amplo, a confirmação dos problemas sociais já existentes. A concentração de renda, característica do país até hoje, pode ser tida como herança daquele período: “[...] a sociedade brasileira poderia manter-se desigual, com renda concentrada, injusta, mas dinâmica" (EARP; PRADO, 2007, p. 230). Porém, como bem podemos imaginar, não era essa a imagem do Brasil tornada pública por parte do governo: procuraram criar um clima ufanista de triunfalismo, tendo no Brasil a imagem de um país próspero e tranquilo, de certo modo mágico, e que até o final do século XX estaria entre as potências mundiais (HABERT, 1996, p. 19-20).

\title{
1.3 Revista Realidade, uma revista de reportagens
}

Uma sociedade em franca transformação, com a eclosão de novos valores, fez com que as demandas da mídia impressa gerassem novos produtos. É nesse contexto que é lançada uma das revistas que conquistou o público leitor a partir de sua variedade de temas e estilos, traduzidos em grandes reportagens: Realidade. "A cobertura era ampla e ambiciosa. A revista traçava uma espécie de mapa da realidade contemporânea, sem resistência a esta ou aquela pauta. O mundo - e o Brasil, em especial - eram desvendados de modo multifacetado" (VILAS BOAS, 1996, p. 92), o que dava subsídios para uma análise do Brasil por parte dos brasileiros, a partir das mais diversas personagens que compunham o mesmo território.

Em meio à generalização de costumes mundiais, momento que coincide com o estabelecimento do mercado editorial brasileiro, observamos a chegada de alguns dos mais 
importantes veículos da história da nossa imprensa, como é o caso de Realidade, publicação da Editora Abril. Estampando uma capa na qual o jovem e já conhecido jogador de futebol Pelé utiliza um busby (Figura 1), alusão ao possível 'reinado' da seleção brasileira na Copa do Mundo da Inglaterra em 1966, a nova publicação esgotou a tiragem de 250 mil exemplares em apenas três dias: era uma revista vendida por segundo, segundo os cálculos realizados pelo jornalista Mylton Severiano (2013, p. 61).

Figura 1 - Capa do número de estreia da revista Realidade, abril de 1966

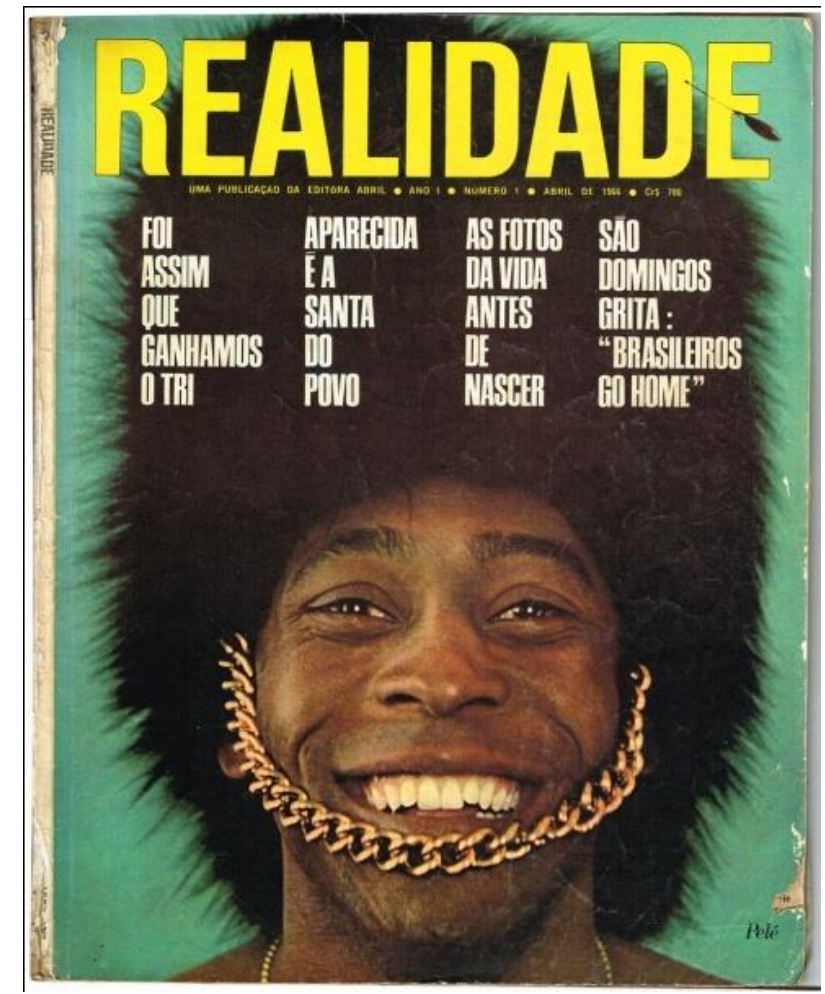

Fonte: Acervo do Grupo de Pesquisa Estudos Fotográficos (UFCA/CNPq)

$\mathrm{O}$ período que antecede à chegada da revista Realidade às bancas de jornal brasileiras $^{7}$, em abril de 1966, foi marcado por fortes mudanças culturais na sociedade da época, conforme descrevemos. A título de exemplo, podemos citar: a) a efetivação da televisão enquanto veículo de comunicação e entretenimento, b) a chegada do chamado 'modo de vida americano', c) o surgimento de um cinema que preza pela busca de uma identidade nacional, bem como $d$ ) a adoção, por parte das mídias, de novas linguagens, as quais enriquecem os meios e os temas abordados.

\footnotetext{
${ }^{7}$ Realidade circulou também em Portugal, a partir do número 34, publicado em janeiro de 1969.
} 
A partir das demandas socioculturais, surgem novos veículos de comunicação, entre os quais esta revista essencialmente de reportagens, propondo-se a apresentar um outro Brasil aos brasileiros. A partir de reportagens realizadas após dias, às vezes meses, de vivência e experiência junto à comunidade, ao indivíduo ou mesmo à cultura profissional em questão, Realidade montou um panorama do país visto a seu modo, do qual pretendemos nos aproximar neste trabalho.

\subsubsection{Realidade: um sonho possível}

O livro A Revista no Brasil, publicação lançada em comemoração aos 50 anos da Editora Abril, afirma que Realidade “[...] refletia a inquietação cultural e de costumes dos anos de 1960, repercutindo novos padrões de comportamento" (2000, p. 57). Lembra, ainda, que a publicação oferecia um padrão de reportagens até então desconhecido no país: "Não economizava espaço. Suas reportagens eram fluviais, exaustivas, e os textos, elaborados com esmero literário" (2000, p. 57), de forma que

Realidade retratou um Brasil que se transformava, tratando de assuntos que, em pleno regime militar, sob censura, não apareciam em outras revistas: a maconha, o clero de esquerda, o casamento de padres, o racismo, a fome. Mostrou um país que também não saia com profundidade na imprensa da época: as mazelas do Nordeste, uma Amazônia desconhecida, os problemas das grandes cidades (CORREA, 2008, p. 216, grifo do autor).

A publicação inovou, tecnicamente, na maneira como se utilizou de textos e imagens para a construção das narrativas. Por esse motivo, é considerada até hoje exemplo de qualidade jornalística. Como uma das principais características de Realidade, destacamos que as reportagens ali publicadas tratavam de igual forma as duas linguagens, estampando trabalhos compostos por narrativas ora dependentes, ora independentes. O fotógrafo Amâncio Chiodi destaca o papel dado à fotografia nas páginas da revista da Editora Abril:

\footnotetext{
A foto de arte. Não, não a foto-documento. Então, você pegar nas revistas que tinha, não tinha, n'O Cruzeiro não tinha ensaios. Tinha foto-documento. Então, eu acho que foi uma abertura, né? E não era uma revista de arte. Então, pra você vê como que era uma coisa aberta. Ninguém tinha coragem de publicar o ensaio (CHIODI, 2013).
}

A revista em questão foi lançada num momento bastante fecundo do jornalismo impresso brasileiro, no qual estavam em circulação títulos como $O$ Cruzeiro e Manchete. $\mathrm{Na}$ 
mesma época surge, nos Estados Unidos, o estilo denominado new journalism, especialmente representado pelos textos publicados na revista Esquire (PANZER, 2006, p. 22). Neste formato, jornalismo e literatura se confundem, criando uma narrativa aprofundada e o mais próxima possível do que se poderia chamar de realidade.

Outras publicações de caráter semelhante surgiram ao redor do mundo. Alguns pesquisadores, tais como Kucinski (1991) e Vilas Boas (1996) apontam que Realidade teria sido a primeira expressão inspirada no novo jornalismo a surgir no Brasil, seguida do Jornal da Tarde, lançado também em 1966. A justificativa se dá pelo fato de ali haver grande liberdade para que os jornalistas de texto desenvolvessem artigos com características literárias pouco comuns, além de os fotógrafos trabalharem com ensaios fotográficos publicados conjuntamente com os textos escritos.

No entanto, alguns dos jornalistas que trabalharam naquela publicação refutam esta afirmação, alegando terem tido acesso aos títulos publicados no âmbito do novo jornalismo apenas após se desligarem da revista. Mylton Severiano, por exemplo, assinala o desconhecimento da equipe acerca do gênero: “É um equívoco. Um engano. Quando comecei a trabalhar na revista nunca tinha ouvindo falar no New Journalism. Vim a conhecer quando já havia saído da revista. Mesmo a nossa turma não havia percebido ainda esse tal de New Journalism" (SEVERIANO apud MORAES, 2010, p. 189, grifo da autora).

De acordo com a análise realizada por Lima (2009, p. 191), o novo jornalismo foi o ponto final de um caminho onde jornalistas buscavam igualar seus textos com a qualidade narrativa da literatura, sem perder a potencialidade de captação da realidade. Apontado como um dos fundadores do gênero nos Estado Unidos, Tom Wolfe define a forma de escrita que exercitava nos seguintes termos:

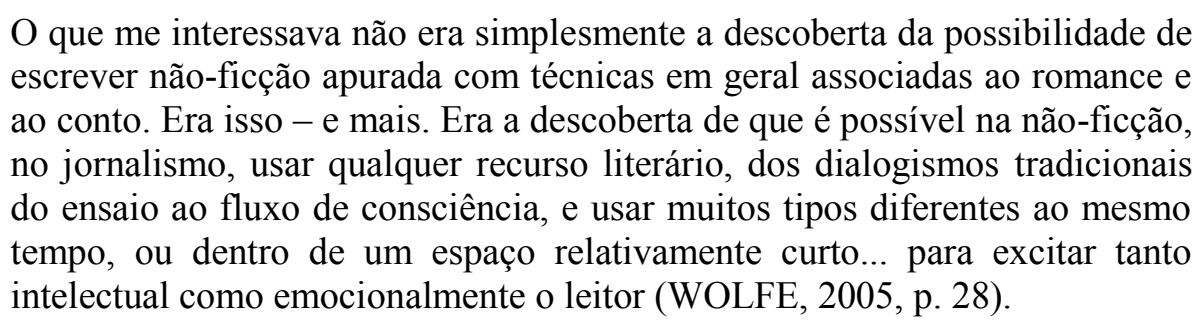

A leitura dos textos enquadrados enquanto pertencentes ao novo jornalismo traz uma nítida impressão de mergulho total do jornalista na realidade, na cotidianidade. Nesses trabalhos, a objetividade dos temas soma-se à subjetividade das impressões do repórter que passava, muitas vezes, meses investigando um mesmo assunto. 
No âmbito da revista Realidade, as reportagens eram alicerçadas na vivência dos repórteres junto às personagens que conduziriam a narrativa. $\mathrm{O}$ trabalho aprofundado exigia tempo, longas viagens e, sobretudo, boa articulação das duplas que se lançavam pelo Brasil em busca de grandes reportagens, imergindo na cultura brasileira e na vida das personagens que tomavam forma nas páginas da revista. Por conta das semelhanças entre os textos de Realidade e as características do Novo Jornalismo, Faro $(1999$, p. 32) afirma que esta seria a escola que mais permitiria se aproximar da compreensão da amplitude da reportagem a partir das necessidades impostas pelo jornalismo.

No ano de 1964, sabia-se que a Editora Abril pretendia lançar uma revista semanal. Originalmente intitulada Revista de Domingo, seria encartada nos jornais Folha de S. Paulo, Jornal do Brasil e Diário de Minas. Corrêa (2008) afirma que "Roberto Civita concebeu a publicação, montou uma redação que juntava alguns dos melhores repórteres e autores de texto da época: a revista tinha que ser boa de ler, e as reportagens tinham que ter impacto e surpresa" (CORRÊA, 2008, p. 215).

No entanto, vale destacar que os jornalistas que fizeram parte de Realidade dão o crédito, na condição de idealizador do projeto, ao também jornalista Paulo Patarra ${ }^{8}$, então diretor da revista Quatro Rodas no ano de 1964. Neste ambiente, Patarra deu início a um processo no qual convidou alguns dos maiores jornalistas do momento a fazer parte de sua equipe, de forma que poderia lançar a candidatura do grupo para a publicação semanal que estaria por ser lançada.

Carlos Azevedo, um dos repórteres que foi levado por Patarra para Quatro Rodas, realizou a reportagem que seria a semente da futura semanal: em 1964, traçou um mapa turístico dos agrupamentos indígenas brasileiros, indicando ao leitor que, diferente do que estava acostumado, não visitasse aqueles locais. O trabalho integrava uma demonstração que o diretor pretendia dar à empresa de que seu grupo estava apto a fazer a revista mensal que viria a ser Realidade, após o fim prematuro da Revista de Domingo (AZEVEDO, 2007, p. 39).

\footnotetext{
${ }^{8}$ Nas palavras de Marão (2008, grifo do autor), Paulo Patarra foi aquele que "conseguiu, durante quase três anos, unir e liderar a equipe da Realidade, uma turma que não era nada fácil. Era meticuloso nas pautas, exigente no resultado. [...] Ele conseguia e tinha adesão de toda a equipe para posições que seriam consideradas 'radicais' e que poderiam parecer suicidas". Disponível em: $<\mathrm{http}: / /$ www.observatoriodaimprensa.com.br/news/view/eledesafiou-a-vida-e-o-jornalismo $>$. Acesso em: 12 set. 2013.
} 
À frente do grupo que realizou os primeiros trabalhos para a publicação estava, além de Paulo Patarra, o editor de texto Sérgio de Souza ${ }^{9}$. O quadro de funcionários já estava parcialmente montado, tendo como profissionais contratados aqueles que faziam parte de veículos de renome na época, alguns da própria Editora Abril, como é o caso de Quatro Rodas e Claudia, por exemplo. Em entrevista cedida a Gil Campos (2007) ${ }^{10}$, Patarra afirma:

Levei para Realidade quase todos os que tinha enfiado na Quatro Rodas e em outras revistas da Abril: o 'maluco beleza' do Narciso Kalili veio de Intervalo, Eduardo Barreto estava escondido em Claudia e Hamilton Almeida Filho, um gênio diabólico, como outros, veio da rua (PATARRA apud CAMPOS, 2007).

Além dos nomes já citados, também foi convidado a integrar a publicação Walter Firmo, primeiro fotógrafo contratado oficialmente para Realidade. Foram realizados ao menos dois números zero para a revista, de forma que a equipe definiu o tipo de jornalismo que pretendia fazer, bem como foi crescendo. Prova desse percurso é a utilização de algumas das reportagens publicadas nas versões de teste na primeira edição que foi às bancas. A partir do lançamento de um dos zeros, pode-se perceber que

[...] nem os repórteres da revista nem os empresários da Abril estavam brincando de fazer jornalismo; ou pelo menos não se tratava de uma aventura. Antes que fosse definitivamente para as bancas com seu primeiro número, uma pesquisa encomendada pela editora ao Instituto de Estudos Sociais e Econômicos (INESE) com base na mensuração dos efeitos do número zero sobre amostragens de leitores potenciais definiu quais eram as demandas que a revista vinha atender: $85 \%$ de leitores entre 18 e 44 anos; $73 \%$ de leitores com escolaridade equivalente ou acima do $2^{\circ}$ grau; $59 \%$ de leitores situados entre as classes B e A. A pesquisa indicou praticamente tudo aquilo que asseguraria o êxito da revista, e sua rápida análise permite verificar que Realidade vinha preencher um vazio na área das revistas de informação não especializada (FARO, 1999, p. 94-95, grifo do autor).

Após consolidar-se, as páginas da publicação estampavam textos cuja produção havia durado semanas, às vezes meses, entre apuração, realização e diagramação. Segundo José Hamilton Ribeiro (2010, p. 202), as duas características primordiais de Realidade eram a

\footnotetext{
${ }^{9}$ Segundo o que foi publicado no site Folha Online, por ocasião de seu falecimento, Sérgio "[...] começou a trabalhar como jornalista na Folha no fim da década de 1950, mesmo sem experiência no ramo. Quatro anos depois, transferiu-se para 'Quatro Rodas', da Editora Abril. Ali, em 1966, faria parte da equipe que fundou e lançou 'Realidade', cujo forte era a reportagem" (Folha Online). Disponível em: $<$ http://www1.folha.uol.com.br/folha/ilustrada/ult90u385660.shtml >. Acesso em 03 jul. 2013.

${ }^{10}$ Disponível em: $<$ http://www.observatoriodaimprensa.com.br/news/view/jornalista-tem-que-saber-ler>. Acesso em: 03 jul. 2013.
} 
vivência dos repórteres quanto às pautas e a qualidade técnica dos textos. Tanto as fotografias quanto os textos tinham de ser, em certa medida, característicos de cada repórter:

A regra era a do estilo pessoal e a da 'experimentação estética' e sensorial.
Nessa medida, o texto haveria de ser o literário, com as possibilidades que
ele permite: o texto que guarda a força expressiva da vivência. Mesclam-se
pontos de vista, imagens, sequências; as reportagens formam um
caleidoscópio que dá às matérias elementos de vínculo com o sensorial do
leitor. A esse quadro se integrava a imagem fotográfica, que não é aqui um
mero acessório do texto - como em $O$ Cruzeiro, Manchete e Fatos e Fotos -,
mas sua expressão visual, integrado a ele (FARO, 1999, p. 90, grifo do
autor).

Além das características de Realidade já citadas, Faro (1999) destaca mais uma que, em sua leitura, foi primordial para o sucesso e a boa aceitação por parte do público: a revista funcionava com uma redação que "[...] gozava de grande autonomia na orientação de cada número que ia às bancas, embora pertencesse a grupo editorial cujas relações com o poder do Estado autoritário e com o capital estrangeiro vinham sendo denunciadas à época do lançamento da revista" (FARO, 1999, p. 82).

Patarra esquematizou qual seria o formato daquela nova revista: uma publicação mensal que utilizaria cor e papel de qualidade; bem editada; de interesse geral; e com boa escolha de assuntos e qualidade de texto, a fim de adquirir prestígio; já os leitores seriam aqueles que tinham interesse pelas fotografias e crônicas de Manchete, pela variedade de conteúdos de O Cruzeiro, pela moda de Claudia, Jóia e Manequim, por viagens, ciência, mecânica e progresso, presentes em Quatro Rodas, Mecânica Popular e Auto Esporte, pelo modelo de revistas estrangeiras e, além disso, os leitores de jornais (SEVERIANO, 2013, p. 77-78).

Faro (1999, p. 81) afirma que alguns elementos externos à editora teriam tornado possível o surgimento de uma revista com o formato de Realidade. Entre eles, destacamos dois: a) o quadro político brasileiro, que possibilitou a explicitação das questões nacionalistas e a crescente participação das massas urbanas na sociedade, bem como $b$ ) a necessidade de uma mídia que acompanhasse, de forma objetiva e efetiva, a vida nacional. As características de Realidade se davam, especialmente, quanto ao tratamento e apresentação da informação. Moraes (2010, p. 20) destaca a semelhança entre os textos da revista e obras literárias, uma vez que havia a construção das personagens e das cenas, a reprodução de diálogos e a variação do foco narrativo. 
Audálio Dantas relata que as normas que guiavam internamente a equipe, no momento de execução da reportagem, eram de liberdade para ambos os profissionais:

Se partiu do ponto de vista de que a imagem era parte integrante, parte da informação, parte não, era a informação! A imagem, a fotografia, não era apenas uma ilustração [...] Então, esse texto criativo, esse texto literário, também valia para a fotografia, na medida em que ela interpretava o tema (DANTAS, 2013).

Portanto, Realidade tinha como objetivo principal ser uma revista de reportagens. Propunha-se a reconhecer o Brasil, redescobrindo-o a partir das propostas de pauta: apresentava um novo país aos brasileiros, utilizando-se, como afirmou Almeida (2010, p. 308), de pessoas simples como personagens, o que se tornou uma particularidade da revista. Poderia haver certa identificação entre os leitores e as personagens das reportagens, o que converge com o que afirma Motta (2005, p. 08): “Ao narrar, alguém está explorando na sua imaginação possíveis desenvolvimentos (reais ou ficcionais) das condutas e comportamentos humanos $[\ldots] "$.

Quanto à forma como a equipe lidava com as matérias, a interação ia desde a elaboração das sugestões de pautas, em reuniões particulares articuladas antes das oficiais, estas na presença de Roberto Civita (AZEVEDO, 2007, p. 100), até a diagramação das reportagens. Severiano (2013) lembra os episódios nos quais repórteres de texto, fotógrafos, editores e até mesmo o office-boy se reuniam para escolher as fotografias que iriam compor as páginas da revista:

A escolha das fotos era o cineminha. Os cromos vinham emoldurados - os eslaides. Conseguíamos um local na penumbra. Alguém operava o aparato e ia projetando as fotos na parede. Repórter e fotógrafo só não apareciam se estivessem viajando. Dali sairia a primeira escolha. Palpites eram bemvindos (SEVERIANO, 2013, p. 192, grifo do autor).

Se Realidade lidava diretamente com personagens que tinham por natureza a possibilidade de se tornarem, em certa medida, identificáveis para com o leitor, o fazia também com relação aos temas abordados: tratava de sexualidade, miséria, fome, mulher, prostituição, enfim, problemas e tabus que assolavam a sociedade, em plenos anos da ditadura militar, contribuindo para a construção dos pensamentos político e cultural daquele momento histórico, em consonância com o que se buscava em grande parte dos países na década de 1960: “[...] todo tipo de repressão à natureza humana e conservadorismos ligados ao status 
quo social foram alvo de discussões e combates, que iam às vias de fato nas ruas, tornadas campos de batalha" (MORAES, 2010, p. 29, grifo do autor).

Conforme descreve Faro (1999), Realidade surgiu atrelada ao período históricocultural no qual foi lançada, na medida em que situava o leitor nas problemáticas de seu tempo, apontando características de uma crise do contemporâneo: "A revista procurava dar ao público a dimensão essencial de suas indagações através de uma extraordinária variedade temática [...] Mas numa pauta nada aleatória, muito menos um universo de situações que não guardavam relação entre si [...]" (FARO, 1999, p. 89).

Por tais características, Realidade é tratada, academicamente, como uma publicação com significativa contribuição para o entendimento dos contextos social, político e cultural das décadas de 1960 e 1970, já tendo sido analisada a partir dos campos de estudo da história $^{11}$, da linguística ${ }^{12}$ e da comunicação ${ }^{13}$.

Indo mais além, Faro (1999) afirma que Realidade

[...] é um marco na história do jornalismo brasileiro. Sob qualquer ângulo que possa ser estudada, a publicação da Editora Abril, [...] produzida durante 10 anos consecutivos, representa para os profissionais da imprensa e para os estudiosos da vida cultural brasileira um momento obrigatório de referência, tanto pela abrangência dos temas que reportou como pela forma como o fez (FARO, 1999, p. 13).

\footnotetext{
${ }^{11}$ LEISTER FILHO, Adalberto. A realidade em revista, a revista Realidade. A memória dos jornalistas de uma publicação revolucionária. Pesquisa de Iniciação Científica financiada pela Fundação de Amparo à Pesquisa do Estado de São Paulo (Fapesp) e concluída em 1997; BOTELHO, Rosana Ulhôa. Sob o Signo do Perigo: o Estatuto do Jovem no Século da Criança e do Adolescente. Brasília, 2000. Tese (Doutorado em História), Universidade de Brasília. ALVES, Valéria Aparecida. Para não dizer que não falei dos festivais. Música e política na década de 60. São Paulo, 2001. Dissertação (Mestrado em História), Faculdade de Ciências Sociais, Pontifícia Universidade Católica de São Paulo; e ROSA, Márcia Eliane. Os sentidos pluralistas do cotidiano da cultura nas reportagens da revista Realidade nos anos de 1966 a 1968. São Paulo, 2006. Tese (Doutorado), Escola de Comunicação e Artes, Universidade de São Paulo.

${ }^{12}$ BARZOTTO, Valdir Heitor. Leituras de Revistas Periódicas: forma, texto e discurso, um estudo sobre a revista Realidade (1966 - 1976). Campinas, 1998. Tese (Doutorado em Linguística), Instituto de Estudos da Linguagem - Universidade de Campinas.

${ }^{13}$ FERNANDES, Terezinha Tagé Dias. Jorge Andrade, repórter Asmodeu: leitura do discurso jornalístico de autor na revista "Realidade". São Paulo, 1988. Tese (Doutorado), Escola de Comunicação e Artes, Universidade de São Paulo; LIMA, Edvaldo Pereira. O Livro-reportagem como extensão do jornalismo impresso: realidade e potencialidade. São Paulo, 1990. Tese (Doutorado), Escola de Comunicação e Artes, Universidade de São Paulo; FARO, José Salvador. Revista REALIDADE - 1966-1968 - Tempo de reportagem na imprensa brasileira. Ulbra/AGE, 1999; MORAES, Letícia Nunes de. Cartas ao Editor: leituras da revista Realidade (1966-1968). São Paulo: Alameda, 2007; e MORAES, Vaniucha de. Realidade (Re)vista: O Papel do Intelectual na Concepção de um Projeto Revolucionário. 2010. Dissertação (Mestrado em Jornalismo) - Universidade Federal de Santa Catarina, Florianópolis, 2010.
} 
Estando qualquer narrativa atrelada ao contexto no qual foi escrita ou publicada, a revista Realidade já se mostraria um importante retrato de uma época. No entanto, para além do comumente encontrado em textos, a revista se propunha a desvendar um Brasil ainda pouco conhecido, dando ênfase a questões de interesse nacional pouco tratadas na época, o que potencializa o viés crítico de um jornalismo que busca uma aproximação para com a realidade social na qual se vê inserido. Scalzo (2008, p. 17) lembra que, naquele momento em que Realidade foi às bancas, o país apresentava a necessidade de se conhecer melhor, de forma que a publicação ajudou nesta empreitada.

Desta forma, entender como as temáticas foram abordadas por Realidade, quais personagens fazem parte das narrativas, o que foi relatado, quais os enredos e conflitos selecionados para compor os textos, apresenta-se como uma forma de compreender, por meio dos discursos da época, como se deu a reflexão acerca das contradições da sociedade brasileira a partir da contribuição dessa revista de grande circulação ${ }^{14}$.

\subsubsection{Uma publicação de três faces}

Os autores que se propuseram a estudar a revista Realidade anteriormente apontam a existência de três distintas fases naquela publicação. A primeira estaria fixada entre abril de 1966 e dezembro de 1968; a segunda, entre janeiro de 1969 e setembro de 1973; ao passo que a terceira tem início em outubro de 1973 e vai até março de 1976, quando a revista é tirada de circulação. Ao todo, foram exatamente 120 números publicados ${ }^{15}$.

"A primeira fase, a chamada fase áurea, é a que ficou para a História. Para alguns, Realidade teve apenas uma fase, que durou de fins de 1965, na preparação dos números zero [...], até dezembro de 1968" (MARÃO, 2010, p. 36, grifo do autor). É nestes termos que José Carlos Marão, jornalista que fez parte dos quadros da revista desde o primeiro número até o final da primeira fase, descreve aquele período. O repórter ainda retornou para Realidade em meados de 1969, juntamente com o também notícipe José Hamilton Ribeiro.

\footnotetext{
${ }^{14}$ Em fevereiro de 1967, no $\mathrm{n}^{\mathrm{o}} 11$, Realidade atingiu uma tiragem de 505.300 exemplares. Segundo o Censo Demográfico da época, a população brasileira no início da década de 1960 era de cerca de 71 milhões de habitantes, ao passo que em 1970 passava de 94 milhões. Disponível em: $<$ http://www.censo2010.ibge.gov.br/sinopse/index.php?dados=4\&uf=00>. Acesso em: 26 set. 2013.

${ }^{15}$ A coleção completa da revista Realidade pode ser acessada através do acervo da Hemeroteca Digital Brasileira / Biblioteca Nacional Digital Brasil (Fundação Biblioteca Nacional), disponível no endereço eletrônico http://memoria.bn.br/DOCREADER/DOCREADER.ASPX?BIB=213659.
} 
Esse período foi marcado por diversos acontecimentos. Entre eles, podemos destacar a apreensão do número dez (Figura 2), de janeiro de 1967, recolhido em parte nas bancas e em parte na gráfica. Tal número era inteiramente dedicado à mulher brasileira, contando com pesquisas, entrevistas e textos que tratavam da maternidade e da independência econômica e sexual, assuntos que, segundo a justiça da época, atentavam contra a moral e os bons costumes.

Figura 2 - Capa da edição especial de Realidade sobre a mulher brasileira, janeiro de 1967

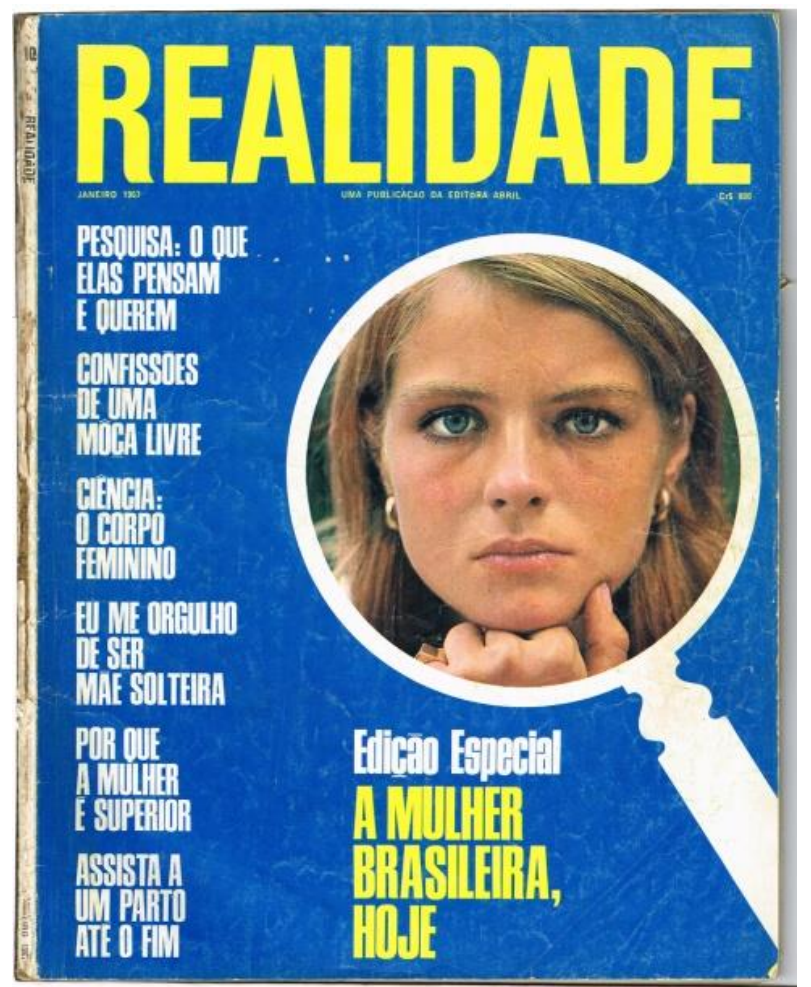

Fonte: Acervo do Grupo de Pesquisa Estudos Fotográficos (UFCA/CNPq)

A reportagem apontada como principal responsável pela apreensão daquele número é assinada por Narciso Kalili (repórter de texto) e Claudia Andujar (fotógrafa). Com o expressivo título Nasceu!, relata um dia de trabalho da parteira Dona Odila, na cidade de Bento Gonçalves, localizada no interior do Rio Grande do Sul. Sobre a edição e diagramação de tal reportagem, Severiano (2013), à época um dos editores de texto de Realidade, descreve:

Diante das fotos de Claudia, aconteceria uma das mais incríveis sessões de discussão política e exercício de autocensura de que participei. A foto de abertura só podia ser a menininha saindo da mãe, justificando o Nasceu!. Claudia fotografou de frente: Odila ampara a cabecinha puxando-a para o mundo. Hoje qualquer tevê mostra, mas estávamos na época em que se dizia 
à criança que ela nascia num pé de couve, ou a cegonha trazia. E era regime militar pé-de-chumbo (SEVERIANO, 2013, p. 107, grifo do autor).

Ao longo dos trinta e três números que contemplam a primeira fase de Realidade, variados temas foram tratados, dentre eles o celibato entre os padres, a vida dos índios em meio à floresta, a miséria nordestina, o caso dos menores abandonados, enfim, um leque de pautas ${ }^{16}$ que demonstra como a publicação se propunha a apresentar outra faceta do Brasil aos brasileiros, em consonância com o que veio explicado no editorial do número seis: "REALIDADE parte do princípio de que seus leitores são adultos, inteligentes e interessados em saber a verdade. E continuará fiel ao seu compromisso de informar. Com imparcialidade, com serenidade. E com a coragem de enfrentar os fatos" (EDITORIAL, 1966, p. 03).

Prova desse compromisso pode ser percebida no número 33 (dezembro de 1968), quando Realidade publica uma entrevista realizada por Paulo Patarra com o líder comunista Luís Carlos Prestes. Esse foi o último trabalho do jornalista para a publicação. Naquela ocasião, a primeira equipe da revista já estava desfeita. Patarra foi afastado de Realidade logo após o fechamento do número 32, no final de outubro daquele ano (SEVERIANO, 2013, p. $303)$.

Ainda em dezembro, paralelo à promulgação do Ato Institucional $\mathrm{N}^{0} 5^{17}$, a maior parte da equipe pediu demissão. Segundo Azevedo, saíram ao menos onze pessoas em um mesmo dia (2007, p. 242). Faro (1999, p. 20) classifica a ocasião como sendo uma das mais descaracterizadoras da revista, uma vez que, mesmo continuando a publicar textos com qualidade jornalística, a partir de 1969 deixaria de se reportar às tendências iniciais da publicação. Porém, esta não é a opinião de parte dos repórteres que continuaram na publicação. O jornalista Raimundo Pereira, por exemplo, descreve a ação da equipe de Realidade como tendo cunho político:

Fizemos um bando de coisas, eu acho que é um trabalho, realmente ficou espetacular, uma coisa assim interessante mesmo. Mesmo do ponto de vista político porque nós fomos muito habilidosos, fomos atrás dos fatos e

\footnotetext{
${ }^{16}$ Baseado em pesquisa realizada em acervo particular da revista, pertencente ao professor Dr. Marcelo Eduardo Leite.

17 "O AI-5, que, ao contrário dos atos anteriores, vigoraria por prazo indefinido, dava ao presidente, entre outras prerrogativas, o poder de cassar políticos, fechar o Congresso, suspender o habeas corpus, impor censura prévia à imprensa, aposentar compulsoriamente professores universitários, prender dissidentes. Costa e Silva faria tudo isso. Qualquer vestígio de oposição seria sufocado. Como definiria a crônica política, o AI-5 foi o golpe dentro do golpe, o início dos Anos de Chumbo" (PILAGALLO, 2004, p. 65).
} 
deixamos de lado interpretações que poderia ofender os militares, porque tinha a censura (PEREIRA, 2013).

Após a saída de parte da equipe dos quadros iniciais de Realidade, o repórter Milton Coelho passa a ser redator-chefe, na condição de interventor (SEVERIANO, 2013, p. 304). Em tempo, ressaltamos que os profissionais que se desligaram da revista naquela ocasião eram repórteres de texto, diagramadores ou editores. Os repórteres fotográficos, por sua vez, continuaram desenvolvendo trabalhos para a publicação, como é o caso de George Love, Claudia Andujar, Luigi Mamprin, entre outros, o que contribuiu, em parte, para a manutenção de uma fração da identidade da publicação.

Apesar da demissão coletiva, alguns profissionais retornam para a publicação em meados de 1969, como é o caso de José Carlos Marão e José Hamilton Ribeiro. Sobre esse momento da revista, Marão relata:

As cautelas, nas matérias, eram muito maiores, embora nunca tivesse havido censura dentro de Realidade, como estava ocorrendo em outras redações. A cautela existia agora também nos contatos externos, com entrevistados ou personagens de matérias (MARÃO, 2010, p. 35, grifo do autor).

Personagens que, segundo análise que realizamos nas revistas, continuavam sendo “[...] gente comum, nos quais o leitor podia se projetar. A pauta de Realidade trabalhou muito pouco com celebridades, a não ser em casos inevitáveis como espetáculos ou esportes" (MARÃO, 2010, p. 31, grifo do autor).

No livro Tempo de Reportagem, Dantas (2012) narra seu percurso para apuração de algumas reportagens, dando relevo à escolha de personagens e ao que acontecia nos bastidores da revista. Sobre o trabalho Oh, Minas Gerais!, realizado no final do ano de 1969 e publicado em janeiro de 1970, Dantas relata que a pauta lhe foi entregue por Paulo Mendonça, diretor de Realidade na ocasião, e que teve duas ou três semanas para conviver com os mineiros e selecionar personagens: "Fomos [o repórter de texto Audálio Dantas e o fotógrafo Luigi Mamprin]. Começamos por escolher personagens que representassem o jeito mineiro de ser. Juntos, eles comporiam um retrato de Minas. Melhor dizendo, um painel" (DANTAS, 2012, p. 79). 
A produção jornalística da segunda fase de Realidade se destaca de forma particular em função das edições chamadas 'especiais'; são elas: Amazônia (1971), Nordeste (1972) e Cidades $(1972)^{18}$. Sobre tais experiências, o repórter e editor Audálio Dantas relata:

[...] era um tipo de jornalismo de investimento na matéria. Que não se faz mais hoje, uma edição dessas da Amazônia levou um contingente imenso de repórteres para todos os pontos da região, assim como Nordeste, meia redação da Realidade foi para Recife, montamos uma redação no Recife. Essas coisas são impensáveis hoje, e significava um investimento muito grande, em dinheiro, não só de tempo dos repórteres e tal, mas dinheiro. A redação ficou em um andar inteiro em um hotel no Recife, e depois transporte para todo o Nordeste, todo esse tipo de coisa (DEPOIMENTO..., 2012).

Raimundo Pereira, responsável pelas edições Amazônia e Cidades, descreve o processo que culminou com a chegada do primeiro dos três números especiais às bancas. Segundo ele, havia nos corredores da editora certo burburinho acerca do montante de dinheiro despendido com a edição, a qual supostamente não seria lucrativa para a empresa:

Nós fomos uns, assim, mais ou menos, meia dúzia de repórteres que eu contratei, Hamiltinho e eu. Contratei o Sergio Buarque, o Lúcio Flávio Pinto, o Otávio Ribeiro, e, fotógrafos, o Solari, o Chiodi, a Claudia, o George Love, a Maureen. E ficamos meio ano na Amazônia trabalhando, preparando essa edição, depois ficamos mais, eu só sei que no total devem ter sido uns nove meses ou dez meses, ou talvez até um pouco mais. Uma edição que foi assim um sucesso estrondoso, em uma semana mais de trezentos mil exemplares (PEREIRA, 2013).

Mesmo após as mudanças na equipe, algumas das principais características de Realidade ainda podem ser observadas, apesar de não verificarmos mais a mesma quantidade de pautas que tratavam diretamente do cenário político. As temáticas continuaram a examinar problemas da sociedade brasileira como um todo, apesar da cautela imposta pelo momento. Em Eu sou João, homem sem leitura, por exemplo, reportagem publicada em setembro de 1970 ( $\mathrm{n}^{\mathrm{o}}$ 54), com texto de José Hamilton Ribeiro e fotografias de Amâncio Chiodi, é apresentado aos leitores a personagem de João, um morador do interior de São Paulo, que se dedica a aprender a ler. José Hamilton define a pauta nos termos reproduzidos a seguir:

No meio da década de 60 [...] a taxa de analfabetismo [...] entre adultos no Brasil causou constrangimento e vergonha. Só na cidade de São Paulo, entre a população com mais de 14 anos, havia 500 mil analfabetos. O Governo

\footnotetext{
${ }^{18}$ Baseado em levantamentos realizados na coleção particular do professor Dr. Marcelo Eduardo Leite.
} 
Federal iniciou então uma campanha de alfabetização em todo o país, envolvendo educadores, artistas, entidades civis. Nesse clima fui conhecer um 'meia-cuié' que vivia em São Paulo (RIBEIRO, 2010, p. 311).

Ainda em suas memórias, Audálio Dantas relata uma cena de autocensura na redação de Realidade, situação antes pouco vista. Enquanto realizavam a vivência para a reportagem Doença de Menino, em janeiro de 1970, tendo como tema a mortalidade de crianças na Zona da Mata pernambucana, o fotógrafo Luigi Mamprin acompanhou o enterro de um infante de apenas sete meses, o chamado 'anjo':

Na redação de Realidade, a foto de Charles no caixãozinho branco que Severino, seu pai, levava na cabeça até o Cemitério de Beberibe passava de mão em mão. Poderia ser a capa da revista, diziam uns, 'para mostrar a situação de miséria em que vive o país'; mas logo vinha a ponderação: Imagina se a censura vai deixar! (DANTAS, 2012, p. 98-99).

Os profissionais da revista relatam que a dinâmica interna da redação modificou-se, a partir da intensificação da censura. Além da autocensura, já vista nos exemplos anteriores, nos últimos anos as mudanças impactaram no tempo para realização das reportagens. Jean Solari, fotógrafo franco-brasileiro que trabalhou para a Realidade entre 1968 e 1973, descreve o processo de escolha e elaboração das pautas:

Fechava uma revista, a gente tinha uma reunião de pauta, todos participavam, o repórter, o fotógrafo, até... todo mundo, todo mundo participava. E era discutida a pauta. Então, "ah, você vai fazer isso, você vai fazer aquilo". Você propunha uma ideia, de repente você ali fazia esse negócio. E era muito democrático. Você tinha quinze dias para fazer a matéria e depois o fechamento da revista. [...] No final, na época das últimas revistas, a gente tinha que mandar essa pauta para Brasília, eles seguravam quinze dias, ai você tinha uma semana pra fazer a matéria (SOLARI, 2013).

Outro exemplo que reafirma a existências de pautas de cunho social nesta fase da revista é a reportagem intitulada Povo Caranguejo, publicada também em 1970 (Figura 3), à qual retornaremos no Capítulo VI. Nela, Audálio Dantas e Maureen Bisilliat narram a experiência dos catadores de caranguejo do povoado de Livramento, situado no município de Santa Rita, litoral do estado da Paraíba. No texto, a permuta de narradores é indicada por meio da mudança de tipografia, de forma que Dantas dá voz ora ao caçador, ora ao caranguejo, que vão descrevendo a situação na qual vivem. Por sua vez, Bisilliat explicita a intimidade que 
atingiu com o ambiente, criando uma narrativa que se situa entre a documentação e a fotografia enquanto expressão.

Figura 3 - Capa da edição de no 48 de Realidade, março de 1970

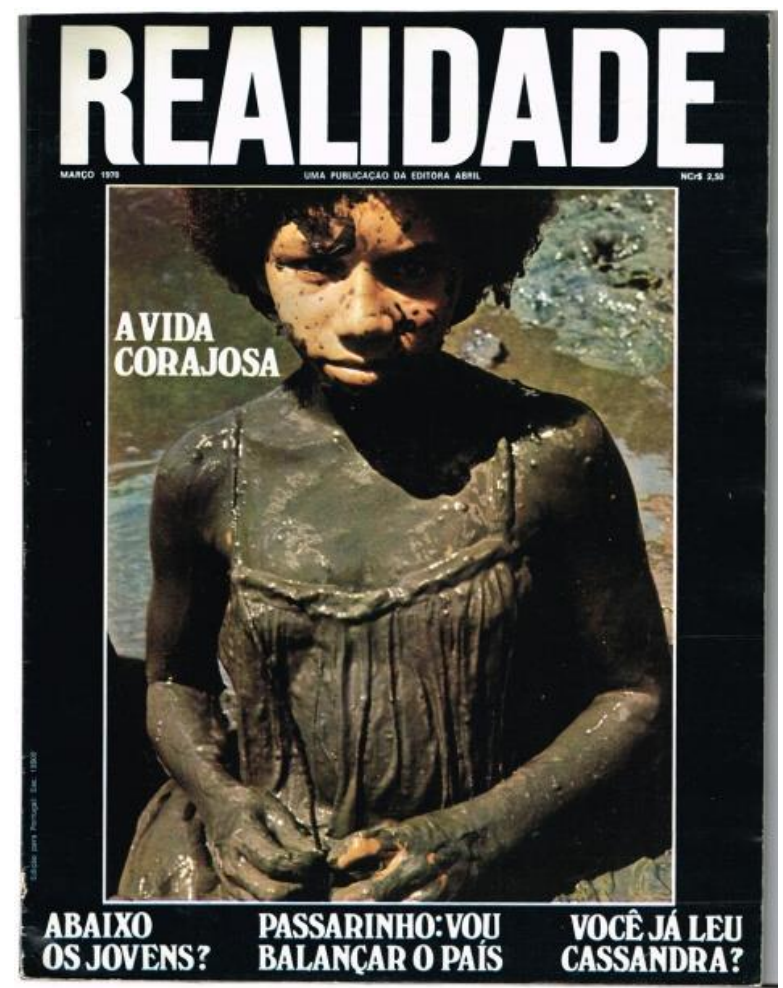

Fonte: Acervo do Grupo de Pesquisa Estudos Fotográficos (UFCA/CNPq)

Em outubro de 1973, após algumas reformulações mais severas, Realidade passa a uma formatação diferente: do ponto de vista físico, passa a ter dimensões menores (de $305 \times 235 \mathrm{~mm}$ é reduzida para $275 \times 210 \mathrm{~mm}$ ), quanto ao conteúdo, não mais pode ser tida como uma revista de reportagens, passando a um modelo semelhante ao da revista Seleções, do Reader's Digest, perdurando até o início de 1976.

Um dos principais motivos alegados como responsáveis pelo fechamento da revista é a consolidação das telecomunicações enquanto parte do cotidiano dos brasileiros, bem como o estabelecimento das revistas semanais de informação, como é o caso de Veja, da própria Editora Abril, lançada em 1968 (CORRÊA, 2008, p. 216). Além disso, em 1976 Realidade também encontrava dificuldades para alimentar seu projeto editorial, onde os jornalistas produziam o jornalismo de texto, além de, é claro, as dificuldades ligadas às restrições impostas pelo fechamento político (BAPTISTA; ABREU, 2010, p. 16). 
Estas considerações nos permitem desenhar o espírito das reportagens e mesmo da redação de Realidade, especialmente em suas duas primeiras fases. No próximo capítulo, trataremos das questões teóricas que fundamentam a nossa investigação. Aqui, entendemos os textos jornalísticos enquanto narrativas. No entanto, para além da formulação linguística do texto, vemos nas narrativas reflexos do contexto sociocultural no qual elas foram produzidas. A seguir, veremos como tais narrativas podem nos ajudar a compreender como certas personagens daquele momento histórico foram reconstruídos pelo veículo e, sobretudo, o que eles podem nos contar. 
CAPÍTULO II

\section{ANÁLISE DA NARRATIVA: UM PROCEDIMENTO PARA INVESTIGAR O TEXTO JORNALÍSTICO}

Em nosso cotidiano, utilizamos amplamente o termo cultura ligando-o aos movimentos artísticos, segmentando-a em erudita e popular. Em alguns casos, quando falamos em valorização da cultura, por exemplo, referimos-nos às características de uma determinada parcela da sociedade, incluindo ali comidas, vestimentas, formas de falar e cerimônias de todos os tipos. Neste trabalho, no entanto, tomamos cultura como "[...] uma dimensão do conhecimento que uma sociedade tem sobre si mesma, sobre outras sociedades, e inclui ainda as maneiras como esse conhecimento é expresso por meio da arte, da religião, do esporte, da ciência, da política” (MOTA, 2008, p. 55).

$\mathrm{Na}$ década de 1960, mais precisamente em 1964, é fundado o Centre for Contemporary Cultural Studies, na Universidade de Birmingham. Os estudos desenvolvidos por tal centro ampliaram o conceito de cultura, estabelecendo o que hoje conhecemos como Estudos Culturais. De acordo com Mota (2008), a tradição criada por esses estudos foi a de uma avaliação moral da sociedade através de um viés político: as pesquisas, não puramente acadêmicas, visam à reconstrução social e à mudança das estruturas de dominação, especialmente aquelas ligadas ao capitalismo industrial.

Os Estudos Culturais se diferenciam das demais formas de pesquisa por buscarem em referências materiais, tais como a linguagem, as origens para as estruturas de dominação. Nos termos de Kellner,

[...] esses estudos situam a cultura num contexto sócio-histórico no qual esta promove dominação ou resistência, e critica as formas de cultura que fomentam a subordinação. Desse modo, os estudos culturais podem ser distinguidos dos discursos e das teorias idealistas, textualizadas e extremistas que só reconhecem as formas linguísticas como constituintes da cultura e da subjetividade. Os estudos culturais, ao contrário, são materialistas porque se 
atêm às origens e aos efeitos materiais da cultura e aos modos como a cultura se imbrica no processo de dominação ou resistência (KELLNER, 2001, p. 49).

Estamos, assim, envoltos em uma cultura que não é fixa, mas sim está em constante modificação. A mesma é dinâmica e está intimamente ligada à experiência, a qual constrói significados. Esta "é uma definição de cultura enquanto processo, no interior do qual as relações de forças sociais atuam no sentido de priorizar determinadas interpretações, de tornálas socialmente hegemônicas" (MOTA, 2008, p. 56), advinda dos estudos culturais britânicos.

Em meio à trama de relações que compõe a cultura, os meios de comunicação se mostram um campo fértil para a produção de significados culturais. Neles, estamos continuamente construindo e, ao mesmo tempo, tendo acesso a narrativas que perpassam os jogos de poder entre os mais diversos grupos sociais, situados em posições diferentes de poder, mas em contínua disputa identitária. Tomando por base os Estudos Culturais, "[...] vemos a cultura da mídia como um terreno de disputa que reproduz em nível cultural os conflitos fundamentais da sociedade, e não como um instrumento de dominação" (KELLNER, 2001, p. 134, grifo do autor).

Neste sentido, cada palavra que pensamos, dizemos ou escrevemos faz parte de uma narrativa que continuamente construímos sobre nós mesmos ou, a partir de outra perspectiva, para nós mesmos. De modo algum as palavras ou sentidos que articulamos estão desvinculados dos contextos social, histórico, cultural e ideológico nos quais estamos imersos. Tudo o que pensamos, fazemos ou mesmo excluímos em relação à narração de nossas vivências constitui a narrativa de nossas vidas. De forma semelhante, produzimos em nosso imaginário conceitos e sentidos que se referem a outras pessoas e aos mais diversos eventos. O que lemos e observamos se converte, a partir do pensamento, em parte do que somos ou do que emitimos enquanto discurso ${ }^{19}$. A narrativa e o ato de narrar estão intimamente ligados à forma como percebemos o nosso entorno.

Entre os aspectos culturais que são construídos por meio da narrativa, destaca-se a parcela que se refere à identidade. Por meio das narrativas compartilhadas por um grupo, estabelecem-se traços que apontam para a construção de uma identidade que congregue, a partir de determinadas matizes, a relação de pertencimento para com aquele grupo social. As práticas culturais, portanto, contribuem para a construção das identidades. Neste sentido,

\footnotetext{
${ }^{19}$ Tal conceito é aqui entendido nos termos nos quais define o Dicionário de Teoria da Narrativa: "O discurso emana de um locutor, dirige-se a um alocutário, faculta uma referência ao mundo e comporta marcas mais ou menos explícitas da situação em que emerge" (REIS; LOPES, 1988, p. 28).
} 
devemos perceber que a narrativa midiática é uma prática cultural, construída por meio das relações que se estabelecem internamente ao grupo: o veículo e seu público constroem, paulatinamente, um contrato que estabelece as matizes do que será veiculado naquele meio. Nos termos de Mota e Almeida, "O cenário da comunicação é [...] um dos lugares fundamentais onde podemos encontrar a origem sobre como pensamos sobre nós mesmos e sobre os outros" (2015, p. 22). O ato de 'pensar' sobre o qual tratamos é, por conseguinte, a base do pensamento identitário.

Uma das possibilidades de identidade criadas pelos meios de comunicação é a noção de comunidade. Neste aspecto, vivenciamos, por intermédio das mais diversas possibilidades comunicativas, um dos elos de construção da identidade do brasileiro. A nação como comunidade imaginada é composta por meio da vivência, através das trocas sociais: "Como comunidades, as nações possuem laços comuns além do territorial, como a língua nacional, os símbolos, as práticas cotidianas, os processos históricos, a própria colonização, que constroem uma narrativa de unificação de significados" (MOTA; ALMEIDA, 2015, p. 37).

Assim, chegamos a uma das principais características e finalidades da narração: tornar eventos de interesse humano conhecidos pelos demais indivíduos de um grupo, quer sejam pessoas do convívio cotidiano, quer sejam pessoas com as quais não se tem um contato direto estabelecido. No primeiro caso, estão incluídas conversas com amigos e discussões em ambientes acadêmicos, por exemplo. Já no segundo, podemos destacar transmissões de rádio e televisão, publicação e leitura de livros ou jornais, entre outros meios.

Mergulhando nestas narrativas, miramo-nos nas palavras de Gadamer acerca da interpretação de textos:

Quem quiser compreender um texto, realiza sempre um projetar. Tão logo apareça um primeiro sentido no texto, o intérprete prelineia um sentido do todo. Naturalmente que o sentido somente se manifesta porque quem lê o texto lê a partir de determinadas expectativas e na perspectiva de um sentido determinado. A compreensão do que está posto no texto consiste precisamente na elaboração desse projeto prévio, que, obviamente, tem que ir sendo constantemente revisado com base no que se dá conforme se avança na penetração do sentido (GADAMER, 2008, p. 356).

\subsection{Narrativas: formas de retratar o mundo}

A narrativa está intimamente ligada à vivência, à experiência vivida. Inseridos em um contexto que nos exige a socialização, tornamo-nos “[...] seres narrativos, narradores natos, 
atores, personagens e ouvintes de nossas próprias narrativas" (MOTTA, 2013, p. 17). Benjamin dá ênfase à relação entre o ato de narrar e "[...] a faculdade de intercambiar experiências" (1987, p. 198). Ao mesmo tempo em que utilizamos as narrativas visando firmarmo-nos enquanto personagens de uma narrativa do mundo, naquele espaço também intercambiamos experiências com nossos interlocutores.

O leque de possibilidades narrativas está dividido em dois grandes extratos. As estórias, narrativas mais inventivas que realistas, e as histórias, textos produzidos a partir de fatos referenciais ${ }^{20}$, fazem parte do cotidiano, bem como nutrem a forma como observamos o mundo e somos observados em meio ao conjunto de atores que dele participam. "A experiência que passa de pessoa a pessoa é a fonte a que recorreram todos os narradores" (BENJAMIN, 1987, p. 198), ao passo que o ato de narrar está associado ao aconselhamento, dando à narrativa um viés utilitário, incumbindo-a da função de contribuir para a construção dos conceitos morais e éticos da sociedade (BENJAMIN, 1987, p. 200).

No entanto, entre o momento no qual Benjamin define as características de um narrador e mesmo prevê a morte do narrador original, aquele que aconselhava e compartilhava suas experiências, e o momento no qual compartilhamos experiências, na atualidade, podemos supor que houve certa reconfiguração de tal conceito. Resende (2002) defende que ambos os termos, experiência e narrador, transmutam-se em termos que nos fazem entender a configuração das narrativas atuais:

A experiência, na sociedade pós-industrial, ganha outras conotações. Ela tanto deixa de derivar puramente de um tempo estritamente ligado ao real, como também passa a ser, de modo muito mais marcante que em outras épocas, causa/efeito de um significativo processo de midiatização das narrativas. Tais fatores permitem ao narrador, assim como à narrativa, ocupar um outro lugar, em outras condições e, até mesmo, com outras funções (RESENDE, 2002, p. 55).

O texto jornalístico, mediatizado, conforme o acessamos, guarda em si a possibilidade de narrar o mundo, as experiências, quer sejam elas das personagens ou do próprio jornalista. Contudo, esta possibilidade tem de ser explorada. As narrativas do jornalismo diário, dada a configuração atual, esquivam-se da criação de narrativas: “[...] o jornalismo, principalmente quando se restringe à função básica de informar, pouco contribui para a construção de

\footnotetext{
${ }^{20}$ Esta divisão é também utilizada por Motta (2013).
} 
narrativas, no sentido amplo do termo. Ao contrário, produz relatos, sem dúvida alguma, $\operatorname{atrofiados}^{21,}$ (RESENDE, 2002, p. 61).

Neste sentido, narrar implica, portanto, em transpor para o discurso os mais variados tempos e acontecimento, tornando possível aos interlocutores construírem percepções acerca do seu entorno. Mais que isso: "A narrativa põe naturalmente os acontecimentos em perspectiva, une pontos, relaciona coisas, cria o passado, o presente e o futuro, encaixa significados parciais em sucessões, explicações e significações mais estáveis" (MOTTA, 2005 , p. 07 , grifo do autor). A narrativa, ao mesmo tempo em que se propõe a explicar o mundo, também acolhe os interlocutores e lhes permite um ambiente vivido mais consistente.

Gonzaga Motta aponta os principais motivos para estudarmos narrativas; seriam eles: 1) compreender quem somos, a partir da análise de como construímos as narrativas sobre nós mesmos; 2) perceber de que forma representamos o mundo do qual fazemos parte; 3) entender os motivos que nos levam a fazer leituras diferenciadas do mundo, ora fielmente, ora imaginativamente; 4) interpretar as diferentes formas de representação do tempo, tornando-o humano; 5) depreender como as narrativas contribuem para o estabelecimento de consensos a partir de dissensos; e, por fim, 6) entendê-las para contá-las de formas mais apropriadas (MOTTA, 2013, p. 27).

Centrando-nos no segundo motivo apresentado, vislumbramos na análise das narrativas uma possibilidade de "[...] compreender como os homens criam representações $e$ apresentações do mundo" (MOTTA, 2013, p. 32, grifo do autor). Aqui estão inclusos, entre outras possibilidades, os textos tidos como históricos, que se preocupam com a veracidade dos fatos narrados, buscando uma maior proximidade com a chamada realidade do mundo vivido. De forma semelhante, os textos jornalísticos, entendidos enquanto leituras da realidade, também podem ser ajustados a esta definição.

Ainda segundo Motta, “o homem não apenas representa o mundo, mas o constitui na medida em que o nomeia e classifica", de forma que "consolidou-se nas ciências sociais e cognitivas a ideia de que conhecer não é apenas refletir nem representar as coisas, mas construir ou fabricar o mundo" (MOTTA, 2013, p. 33). O mundo vivido, em suma, é construído por meio do pensamento e no pensamento, sendo as narrativas uma forma de organizar a parcela experienciada da vida, ajudando os seres humanos a se reconhecerem e a

\footnotetext{
${ }^{21}$ Resende (2002) opta pelo termo 'atrofiado' a fim de definir aqueles textos jornalísticos que informam sem criar construções narrativas. Em contrapartida, o autor aponta para a possibilidade de existência de narrativas menos estéreis, as quais produzam significados, possuam personagens e narradores, permitindo a reconfiguração do fazer jornalístico.
} 
darem formas, sonoras ou imaginárias, ao que lhes diz respeito. Em outras palavras, a narrativa torna o mundo natural, articulado e organizado.

Quer textos de historiadores, quer textos de jornalistas, ambos propõem-se a narrar os fatos conforme leituras que fazem do ambiente e das relações sociais e culturais ali implicadas. No entanto, temos de ter claro que as palavras que utilizamos para nos comunicarmos, em suma, não nos pertencem. Hall traça, a partir da interpretação do legado teórico de filósofos da linguagem, tais como Jacques Derrida, considerações acerca da intencionalidade do autor ao escrever: "[...] apesar de seus melhores esforços, o/a falante individual não pode, nunca, fixar o significado de uma forma final, incluindo o significado de sua identidade" (HALL, 2006, p. 41), uma vez que não temos controle sobre os códigos da língua, considerando que os mesmos já estão traçados historicamente enquanto que nos encontramos em meio ao processo de construção de nossas próprias narrativas.

O sujeito, envolto em linguagem, torna-se produto dos discursos que povoam o mundo. Nos termos de Stevens, após a problematização acerca da teoria de Saussure realizada por Derrida, "resta-nos apenas a possibilidade de infinitos jogos de linguagem que constroem também o sujeito, entendido agora apenas como uma construção discursiva" (STEVENS, 2007, p. 46).

Ainda segundo o que nos diz a filosofia da linguagem,

Nossas afirmações são baseadas em proposições e premissas das quais nós não temos consciência, mas que são, por assim dizer, conduzidas na corrente sanguínea de nossa língua. Tudo que dizemos tem um 'antes' e um 'depois' - uma 'margem' na qual outras pessoas podem escrever. O significado é inerentemente instável: ele procura o fechamento (a identidade), mas ele é constantemente perturbado (pela diferença). Ele está constantemente escapulindo de nós. Existem sempre significados suplementares sobre os quais não temos qualquer controle, que surgirão e subverterão nossas tentativas para criar mundos fixos e estáveis [...] (HALL, 2006, p. 41).

A linguagem, neste sentido, transcende às regras indicadas pela gramática e assume um papel de significação do mundo, cambiando os significados e as referências dos termos de acordo com os usos e as necessidades. A linguagem é dinâmica e detém um aspecto referencial:

Textos falam e participam das práticas comunicativas em sociedade como o principal meio de transmissão de conceitos, de pontos de vistas, de trocas entre pessoas. A linguagem é, portanto, um objeto de estudos que transcende a ideia de um sistema lógico com regras gramaticas, e que precisa ser 
compreendido na prática social, como linguagem em uso (MOTA, 2008, p. 24).

Partindo da percepção da necessidade de se estudar as narrativas e a linguagem enquanto elementos construtores da significação, a Linguística passa a ser compreendida enquanto parte de uma ciência mais ampla, a Semiologia, campo que se propõe a analisar os discursos a partir do entendimento da relação entre a palavra e a significação. Termo cunhado pelo suíço Ferdinand de Saussure ${ }^{22}$, a Semiologia teria como objeto os signos no seio social (SAUSSURE et al., 1978, p. VIII). Nos termos do próprio Saussure,

A língua é um sistema de signos que exprime ideias [...] Ela é apenas o mais importante desses sistemas. Pode-se, portanto, conceber uma ciência que estude a vida dos signos no seio da vida social; esta formaria uma parte da Psicologia Social e, por consequência, da Psicologia Geral; chamá-la-emos Semiologia (do grego semeion, 'signo'). Tal ciência nos ensinaria no que consistem os signos, quais leis os regem. Uma vez que ela não existe ainda, não se pode dizer o que será; mas ela tem direito a existência [...] (SAUSSURE apud DUCROT; TODOROV, 2001, p. 91, grifo dos autores).

A teoria e a metodologia de Análise da Narrativa nascem ligadas à Semiologia e à análise literária. Em meio aos fatores que contribuíram para seu surgimento, alguns autores podem ser apontados entre aqueles que seriam os principais responsáveis por lançar as bases de tal campo teórico. Entre eles, destacamos Vladimir Propp (1895-1970) ${ }^{23}$, Roland Barthes $(1915-1980)^{24}$, Umberto Eco (1932-) ${ }^{25}$ e Tzvetan Todorov (1939-) ${ }^{26}$.

A Teoria da Narrativa busca nos componentes do discurso elementos que explicitem a enunciação, ou seja, “[...] o ato pelo qual os sujeitos interlocutores criam o sentido através de

\footnotetext{
${ }^{22}$ Linguista e filósofo "[...] nascido no castelo de Vuflens, Genebra, em 1857, e falecido em 1913 no cantão suíço de Vand. Sua obra mais importante, Curso de Lingüística Geral, só foi publicada postumamente em 1916, graças aos esforços de dois discípulos, Charles Bally (1865-1947) e Albert Séchehaye, que recolheram anotações de aulas dadas pelo mestre entre 1906 e 1911" (SAUSSURE et al., 1978, p. VI).

${ }^{23}$ Estruturalista russo, analisou os elementos fundamentais para a construção dos contos populares. Autor de Morfologia do Conto Maravilhoso (1928).

${ }^{24}$ Filósofo e semiólogo francês. Fez parte da escola Estruturalista. Autor, entre outros, dos livros Análise estrutural da narrativa (1973), O óbvio e o obtuso (1990), A câmara clara (1980) e O Grau Zero da escrita (2004).

${ }^{25}$ Escritor, filósofo, semiólogo e linguista italiano. Autor de Apocalípticos e integrados (1964), Lector in fábula (1979), Interpretação e superinterpretação (1992), Sobre a literatura (2002), entre outros. Diretor da Escola Superior de Ciências Humanas da Universidade de Bolonha (Itália).

${ }^{26}$ Filósofo e linguista búlgaro. Autor de mais de vinte livros, entre eles: A gramática do Decameron (1969), A Conquista da América (1982) e Poética da Prosa (2003). Diretor de Pesquisa Honorário do Centro de Pesquisas de Artes e Linguagens, da Escola de Altos Estudos em Ciências Sociais, na França.
} 
performances linguísticas" (MOTTA, 2013, p. 11). Ao discutir os termos enunciado e enunciação, Sodré (2009) também destaca a importância de tais conceitos, de forma que

\footnotetext{
Enunciado é o resultado da ação, o produto fechado ou acabado da prática social de linguagem ou discurso, que tem forma verbal, visual, audiovisual, etc. Quanto à enunciação, costuma ser referida ao ato comunicativo que gerou o enunciado, portanto, às circunstâncias de tempo, lugar e sujeito, necessárias à produção de fala (SODRÉ, 2009, p. 175).
}

Então, neste ponto reside a principal diferença entre a Análise Estrutural e a Análise Crítica da Narrativa. Enquanto a primeira visa à análise puramente linguística, buscando na frase os componentes da enunciação, a segunda vê no contexto, no ambiente externo ao texto, elementos culturais, econômicos e sociais que contribuem de forma decisiva, tanto para a construção da narrativa, quanto para a sua recepção por meio dos leitores.

As bases para a passagem da Análise Estrutural para a Crítica, segundo Motta (2013, p. 12), podem ser encontradas no giro linguístico, na filosofia da linguagem, na antropologia investigativa, na segunda revolução cognitiva, na pragmática e na retórica. O texto passa a ser entendido como uma coconstrução, na qual ambos os interlocutores, escritor e leitor, por exemplo, são responsáveis pelas informações narradas. Mesmo nos produtos da chamada comunicação de massa, como é o caso do jornalismo, onde a resposta é fraca, pode-se entender como havendo ali troca de experiências e informações (MOTTA, 2013, p. 21).

\subsection{Como analisar narrativas? Da Análise Estrutural à Crítica}

A Escola Estruturalista deteve-se, entre outras ciências, sobre a elaboração de uma Teoria do Discurso segundo a Semiologia, fortemente inspirada nos conceitos desenvolvidos por Saussure. A principal obra do autor, voltada para a relação das palavras (significante) com o conceito ao qual elas estão relacionadas (significado), foi o Curso de Linguística Geral, publicado em 1969.

Em meio ao arcabouço teórico lançado pelo estruturalismo, alguns conceitos foram criados tendo em vista a mensagem narrativa. Uma das obras pioneiras sobre este assunto é o livro Análise Estrutural da Narrativa (1973), uma coletânea de ensaios publicados na revista acadêmica francesa Communications. 
Em artigo introdutório ao tema da análise de narrativas, Roland Barthes preocupa-se em definir onde está localizada a importância e a existência das narrativas na experiência vivida:

\begin{abstract}
Inúmeras são as narrativas do mundo. Há em primeiro lugar uma variedade prodigiosa de gêneros, distribuídos entre substâncias diferentes, como se toda matéria fosse boa para que o homem lhe confiasse suas narrativas: a narrativa pode ser sustentada pela linguagem articulada, oral ou escrita, pela imagem, fixa ou móvel, pelo gesto ou pela mistura ordenada de todas estas substâncias [...] (BARTHES, 1973, p. 19).
\end{abstract}

A narrativa, por esta perspectiva, está presente em qualquer lugar no qual haja vida, convívio humano. Não existe povo algum que não tenha criado e repassado suas narrativas, a princípio oralmente, depois de forma escrita. Até hoje é possível observar certo culto à narrativa oral, especialmente em cidades pequenas no interior do país, onde as pessoas com mais idade contam os chamados 'causos' de suas vidas e da história/estória local.

Em se tratando da relação entre o formalismo russo e o estruturalismo, Barthes destaca o legado do primeiro para a teoria nascente:

[...] ou bem a narrativa é uma simples acumulação de acontecimentos, caso em que só se pode falar dela referindo-se à arte, ao talento ou ao gênio do narrador (do autor) - todas formas míticas do acaso -, ou então possui em comum com outras narrativas uma estrutura acessível à análise, mesmo que seja necessária alguma paciência para explicitá-la; pois há um abismo entre a mais complexa aleatória e a mais simples combinatória, e ninguém pode combinar (produzir) uma narrativa, sem se referir a um sistema implícito de unidades e de regras (BARTHES, 1973, p. 20-21).

No entanto, Barthes (1973, p. 21) aponta ainda a necessária construção de um modelo hipotético de descrição das narrativas, o qual seria a base para a análise dos textos: a pluralidade das narrativas só seria passiva de observação a partir de modelos que admitissem espécies diferentes de narrativas que, somadas, dariam conta da infinidade de modos de narrar existentes.

A análise estrutural tem início a partir da elaboração de instâncias de descrição que devem ser postas em perspectiva hierárquica (BARTHES, 1973), os chamados níveis da significação, os quais perpassam a narrativa, não estando presos à frase. Quanto aos níveis de análise, Barthes apresenta uma proposta na qual combina diversas categorias já utilizadas: 
Propõe-se distinguir na obra narrativa três níveis de descrição: o nível das "funções" (no sentido que esta palavra tem em Propp e em Bremond), o nível das "ações" (no sentido que esta palavra tem em Greimas quando fala dos personagens como actantes) e o nível da "narração" (que é, grosso modo, o nível dos "discursos" em Todorov) [...] uma função não tem sentido se não tiver lugar na ação geral de um actante; e a própria ação recebe sua significação última pelo fato de ser narrada, confiada a um discurso que tem seu próprio código (BARTHES, 1973, p. 27).

A partir da proposta teórico-metodológica da análise narrativa na Literatura, alguns autores se propuseram à aplicação de tais conceitos para a análise de textos ligados à comunicação (por exemplo, MOTA; MOTTA; CUNHA, 2012). Neste âmbito, destacamos o trabalho do professor Luiz Gonzaga Motta (2005; 2013), que vem se dedicando a elaborar uma Análise Crítica da Narrativa, tanto na esfera da teoria quanto na metodologia.

Neste contexto, a Análise Crítica da Narrativa propõe-se a “[...] observar a coconstrução de significações na comunicação narrativa. Analisar como as pessoas compreendem, representam e constituem argumentativamente o mundo através de atos de fala narrativos intersubjetivos" (MOTTA, 2013, p. 129, grifo do autor). Desta forma, para além da análise do texto enquanto estrutura puramente linguística, a análise crítica entende que o contexto, o ambiente no qual a narrativa é elaborada e, sobretudo, tornada pública, interfere na forma como ela é apreciada. Dito de outra forma, o contexto define, em parte, o texto final.

Motta (2013), ao apontar as bases para uma teoria crítica da narrativa, contesta a forma de análise estruturalista, em função de uma postura mais voltada para a antropologia e a cultura, estando o foco da análise no contexto comunicativo exterior ao texto. Nos termos de Motta (2013, p. 120), “é inconcebível fazer a análise de um objeto linguístico (a narrativa) como se ele pairasse isolado no espaço estético ou epistemológico". O significado do texto não apenas depende do contexto, mas é construído em meio a ele. Sendo assim,

A análise da narrativa é um caminho rumo ao significado e $o$ significado é
uma relação: não há significado sem algum tipo de troca. Não se pode fazer
análise da narrativa ignorando as relações culturais que se estabelecem no
ato narrativo, desde o princípio. As narrativas são relações argumentativas
que se estabelecem por causa da cultura, da convivência entre seres vivos
com interesses, desejos, vontades, e sob os constrangimentos e as condições
sociais de hierarquia e de poder (MOTTA, 2013, p. 121, grifo do autor).

A proposta levantada por Motta (2013) é uma técnica hermenêutica que torna possível a interpretação dos discursos acerca de uma realidade construída a partir de fenômenos 
concretos e abstratos, dando vistas à ligação de tal teoria e metodologia com a fenomenologia. De acordo com o pensamento de Husserl (2005, p. 06-07), a fenomenologia se refere à descrição da estrutura do fenômeno, um reflexo da consciência do indivíduo, sendo esta uma filosofia transcendental. A reflexão, ao invés de se referir ao que está aparente, debruça-se sobre aquilo que se mostra a nós enquanto seres humanos.

Além da intencionalidade, o texto deve ter um código comum entre o narrador e o leitor: o idioma. Outros códigos também devem ser compartilhados, como é o caso do fator contexto extraverbal. Fazem parte dessa classificação os contextos físico, empírico, prático, histórico e cultural. Cada um versando sobre uma parcela do exterior ao texto, eles compõem a conjuntura que deixa marcas na leitura e que, a depender dos contextos do narrador e do leitor, altera a forma como uma mesma narrativa pode ser lida.

A Análise Crítica da Narrativa, assim, entende o texto enquanto uma estrutura narrativa construída com a intenção de levar o interlocutor a fazer certa interpretação acerca dos fenômenos relatados conforme o objetivo do autor (MOTTA, 2013, p. 127). Esta característica específica do texto deve ser destacada em relação aos produtos jornalísticos. Nestes casos, além da intencionalidade do autor, há também a intencionalidade do meio, do veículo, dos donos do veículo. Em outras palavras, o texto é sempre construído em meio a um jogo de poderes.

Ao trabalhar com o legado teórico da Semiologia e mais especificamente com as obras de Saussure, Barthes e Michel Foucault ${ }^{27}$, Hall (1997), no âmbito dos estudos culturais, estabelece um novo conceito a ser trabalhado quando da análise de produtos discursivos, quer sejam eles iconográficos, fonográficos ou escritos: a representação ${ }^{28}$. Para Hall (1997), vivemos em meio a conceitos que são culturalmente estabelecidos, aceitos e reproduzidos, porém não inertes: assim como a cultura está em constante transformação, os significados, as representações, também o estão.

A tal processo, o autor deu o nome de 'sistema de representações', o qual não é composto por conceitos individuais, mas sim por diferentes formas de organizar e classificar os conceitos, além de relacioná-los de forma complexa (HALL, 1997, p. 17). Desta forma, os elementos - palavras, imagens, desenhos: os significantes - que, como tratamos

\footnotetext{
${ }^{27}$ Filósofo, historiador das ideias, teórico social, filólogo e crítico literário. Considerado estruturalista, suas obras envolvem temas como sexualidade, psiquiatria, poder e discurso.

${ }^{28} \mathrm{O}$ livro no qual o autor trabalha tal conceito, intitulado Representation: Cultural representations and signifying practices, não possui versão em português.
} 
anteriormente, já estão definidos na linguagem antes de os utilizarmos, encontram-se historicamente ligados ao grupo e ao contexto no qual são utilizados.

Uma das implicações de tal constatação é que, uma vez que as convenções linguísticas e sociais estão sempre passíveis de mudança de significado, o mesmo não pode ser nunca 'finalmente' fixado (HALL, 1997, p. 23-24). A representação, por uma perspectiva construtivista, é uma prática, cujo significado tem uma função simbólica (HALL, 1997, p. 26).

Utilizando-se dos termos cunhados por Saussure, Hall (1997, p. 31) afirma que é a relação entre o significante e o significado, fixada em uma determinada cultura, que sustenta a representação, por meio dos signos. Somos nós, imersos na cultura humana, que fazemos as coisas significarem, no momento em que utilizamos certos conceitos compartilhados e, por meio deles, construímos narrativas que comunicam, informam, produzem sentido.

Neste aspecto, destacamos a leitura feita por Barthes (2013), acerca da ressignificação do signo quando em contato com a cultura, por meio do mito. De acordo com o autor, o signo linguístico passa a significante no sistema semiológico do mito, de forma que ele dá origem a um novo signo. O primeiro nível é o da 'denotação', o segundo, o da ‘conotação'.

No nível da denotação temos as palavras e fotografias, enfim, termos que significam por si, mas que, quando encadeados e numa determinada condição histórica e cultural, produzem outro sentido, também determinado. Assim, consideramos os produtos jornalísticos como 'conotações', marcadas historicamente e dotados de significados que podem ser lidos em função dos sentidos sociais construídos naquele momento.

\subsection{A narrativa jornalística e o efeito de real}

Um conceito que nos ajuda a compreender o processo de produção da notícia é o de ordem do discurso, de Foucault (1996). Aqui se deve compreender o espaço social e cultural contexto ou formação discursiva - onde os textos são produzidos. De acordo com Mota, "no jornalismo, a representação linguística se dá como uma forma-notícia, uma estrutura textual que estabelece características objetivas a partir dos cinco Quês. A notícia é, portanto, o texto que emerge de uma prática discursiva própria da instituição imprensa, é o produto de uma atividade social institucionalizada que é a atividade jornalística" (MOTA, 2006, p. 130).

Por meio de tais práticas, os textos são transformados desde as fontes primárias de informação - releases, declarações, falas, testemunhos, enfim, qualquer tipo de enunciado - 
em enunciados concatenados, relatos organizados de forma impessoal dos acontecimentos. Ao entendermos desta forma o discurso, deparamo-nos com aspectos sociais e culturais implicados na narrativa: este "[...] é um objeto de conhecimento da produção de bens culturais (desde textos verbais e escritos até gestos e imagens) e se refere ao que, na língua, é histórico e socialmente prático" (SODRÉ, 2009, p. 141).

Sendo entendidas enquanto discursos, as narrativas históricas e jornalísticas têm suas aproximações. De antemão, ambas se preocupam com o real. A intencionalidade de cada um desses narradores é descrever os fatos. Destacamos aqui que o acontecimento narrado deve, por condição, ter tido impacto para a formação social, econômica ou cultural daquele contexto, ou mesmo daquela sociedade.

Delegamos ao texto o estatuto de real por conta de uma série de artifícios utilizados pelo autor do mesmo. Roland Barthes (1972) chamou de efeito de real a característica de distribuir ao longo do texto uma sequência de pequenos detalhes que poderiam se fazer dispensáveis, mas que estão ali a fim de tornar possível a ligação dos fatos com o mundo vivido do leitor. O que teríamos em mãos, nos termos do autor, seria uma ilusão referencial criada por tais detalhes. No caso dos textos jornalísticos, o referencial, além dos detalhes, se encontra também nos espaços físicos e nas personagens, figuras que podem ser públicas ou anônimas.

A fotografia, um dos elementos construtores dos produtos jornalísticos, contribui de forma singular para a composição do efeito de real. A princípio, a imagem pressupõe que o fotógrafo presenciou o fato, registrando-o no exato momento em que acontecia. Posteriormente, nas páginas dos jornais, revistas ou mesmos nos álbuns de família, "o que a fotografia reproduz ao infinito só ocorreu uma vez: ela repete mecanicamente o que nunca mais poderá repetir-se existencialmente" (BARTHES, 1984, p. 13).

A imagem, ali fixada e reproduzida, uma representação do real, partilha três fases distintas de interação com o mundo exterior, indo desde sua feitura até sua leitura:

[...] uma foto pode ser objeto de três práticas (ou de três intenções): fazer, suportar, olhar. O Operator é o Fotógrafo. O Spectator somos todos nós, que compulsamos, nos jornais, nos livros, nos álbuns, nos arquivos, coleções de fotos. E aquele ou aquela que é fotografado, é o alvo, o referente, espécie de pequeno simulacro, de eídolon emitido pelo objeto, que de bom grado eu chamaria de Spectrum da Fotografia, porque essa palavra mantém, através de sua raiz, uma relação com o 'espetáculo' e a ele acrescenta essa coisa um pouco terrível que há em toda fotografia: o retorno do morto (BARTHES, 1984, p. 20). 
Nesta pesquisa, detemo-nos sobre o que Barthes (1984) chama de studium de uma fotografia. Este autor prefere utilizar um termo em latim para cunhar seus conceitos por acreditar que as palavras francesas - sua língua materna - não expressam completamente o sentido a que se pretende. Segundo ele, as fotografias seriam formadas por dois elementos, por meio dos quais percebemos e apreendemos a mensagem fotográfica: o studium e o punctum. O primeiro, associado à cultura, remete a informações do campo das relações estabelecidas na cotidianidade: é o interesse humano que a fotografia desperta. Já o segundo elemento parte da imagem para o observador, atingindo-o. Transforma-o em relação àquela cultura que o abriga, ferindo-o em função do estado no qual foi encontrado pela fotografia (BARTHES, 1984, p. 44 - 46).

Nas páginas dos jornais temos acesso ao ponto final de um processo que conjuga fases de seleção e elaboração de discursos. No percurso, o jornalista seleciona os temas sobre os quais vai tratar a partir da impressão que tem de seu público. Neste sentido, interesse público e interesse do público se confundem e dão margem para que o veículo escolha as pautas que lhes tragam maior respeito junto aos pares. Em meio a tal jogo de poderes, há uma dupla interação entre o público e o próprio veículo. Nos termos de Sodré (2009),

De um modo geral, na vida concreta, o conteúdo jornalístico exerce efeitos de confronto ou de segurança sobre os leitores habituais. O público-leitor, na realidade, é progressivamente constituído pelo jornal e retroage implícita e explicitamente sobre a produção dos conteúdos (SODRÉ, 2009, p. 96-97).

Outro aspecto que diferencia a narrativa histórica da jornalística é o fator temporal. O texto jornalístico, a notícia, mais especificamente, é construído praticamente de forma paralela ao desenrolar dos acontecimentos. Aqui, entendemos a narrativa jornalística enquanto pertencente à chamada história do tempo presente. A partir desta perspectiva, "[...] percebemos e construímos o sentido do presente como uma história do passado, como uma continuidade entre o que está acontecendo com o que acabou de acontecer" (MOTTA, 2005, p. 29).

No entanto, para além do nível de profundidade e de discussão possibilitadas pelas notícias, há mais formas de exercitar o texto informativo em veículos de comunicação. Uma destas é a reportagem. Texto em geral mais denso em informações e dotado de um maior número de personagens, pode ser o principal objeto de trabalho de uma publicação. Sobre a reportagem, 
O caleidoscópio de fontes e de temas para a elaboração de uma grande matéria provoca um alargamento nos limites do tempo e do espaço - e isso representa algo muito maior do que apenas períodos maiores para apurações e dimensões mais generosas de publicação. Significa que o tema abordado numa reportagem deve ir além da rigidez do "ontem" típica da notícia (MAGNO, 2006, p. 25-26).

Além de lidar com temas e tempos diferenciados, as personagens das reportagens também se diferenciam da dicotomia típica das notícias diárias. Enquanto que a notícia se dá por satisfeita com aquele que está enunciando algo e/ou a fonte oficial - que a contesta ou responde -, as reportagens aprofundam características físicas, psicológicas e sociais dos atores envolvidos no conflito, o que muitas vezes pode trazer ao texto a presença de personagens secundárias, responsáveis por ajudarem a construir a personagem principal. Aqui, chegamos a um ponto chave do conceito de personagem ${ }^{29}:$ “[...] a reprodução da pessoa física no jornal não é a própria pessoa, é uma imagem da pessoa, uma imagem linguisticamente construída, que ressalta certas características e ignora outras [...]" (MOTTA, 2005, p. 75, grifo nosso).

Interligando as parcelas aqui listadas da narrativa, está o narrador ${ }^{30}$. Em se tratando de imprensa, podemos identificar, segundo Motta (2013), três diferentes narradores: a instituição, o jornalista e a personagem. Estes três detêm poder sobre a narrativa, cada um a partir de sua posição em relação ao texto. O primeiro, totalmente externo, ao passo que o segundo e o terceiro são internos. Assim, segue mais detalhadamente o papel de cada narrador para a construção da estória:

O Primeiro-narrador, o jornal como instituição que fala, é extradiegético: enuncia uma estória da qual não tomou parte, não testemunhou nem apurou diretamente. O jornalista, Segundo-narrador, desempenha o papel de narrador intradiegético, dentro da estória, porque ele apura, seleciona, dispõe e hierarquiza as ações, conflitos, personagens, cenas e enredos. A personagem, Terceiro-narrador, é um narrador definitivamente intradiegético e detém menor poder de voz que o jornal e jornalistas na cadeia (MOTTA, 2013, p. 225)

Em nossa leitura, em meio aos elementos que constituem a narrativa, a personagem se destaca, especialmente quando é utilizada na condição de fio condutor da narrativa. Tal opção do jornalista pode ser realizada tanto em coberturas de eventos específicos quanto em

\footnotetext{
${ }^{29}$ Trabalharemos de forma mais aprofundada este conceito no Capítulo III.

${ }^{30}$ No Capítulo III traçaremos uma discussão em torno do conceito de 'narrador' e, em especial, de sua função dentro da narrativa jornalística.
} 
reportagens independentes que vão compor publicações com especial interesse neste tipo de produto jornalístico. Temos em mãos o caso de uma parcela das reportagens publicadas por Realidade em suas duas primeiras fases: elege personagens e escreve a reportagem de forma que toda a narrativa acompanhe aquela pessoa ou grupo, dando vistas a problemáticas sociais com as quais ela - e muitos outros indivíduos - tenha de lidar cotidianamente.

Mesmo tendo verossimilhança com os elementos do universo sensível, as personagens não são as pessoas ditas reais. Esse conceito é especialmente importante no caso do Jornalismo e da História. Por lidarem com eventos que de fato aconteceram, narram episódios vivenciados por pessoas minimamente conhecidas pelos leitores e tornadas, de certo modo, próximas a partir das mídias. A constante interação com a personagem a torna conhecida e naturaliza a relação com a mesma. Trazendo como exemplo a biografia do ex-presidente Lula (PT), Silva (2011) explica a relação entre a personagem da narrativa e a pessoa real:

É comum ao leitor, ouvinte ou telespectador confundir a pessoa real com a personagem. Afinal [...] as pessoa, ou a maioria delas, nunca viram nem mantiveram contato pessoal com o ex-presidente. O que elas conhecem dele é somente a representação midiática, o que foi publicado acerca dele. E é isso que causa uma certa confusão, porque Luis Inácio tem referência no real. Em suma, a criação da personagem é uma atividade estruturante das práticas e do discurso jornalístico. A personagem só existe no papel, é uma figura do discurso, e não deve ser confundida com a pessoa que lhe deu origem (SILVA, 2011, p. 57).

Destacamos, ainda, que há uma forma específica de narrativa na qual narrador e personagem podem confundir-se, entrelaçar-se. Esse é o caso do chamado texto de testemunho. O testemunho é um gênero específico de narrativa que pressupõe que os acontecimentos narrados partem da testemunha (testis) e/ou o sobrevivente (superstes) para a construção do discurso (CUNHA, 2012). Em geral, são narrativas baseadas no medo e na violência, de forma que o jornalista testemunha os acontecimentos e envolve-se com o ambiente. Ele pode, inclusive, ser uma das personagens presentes na narrativa. Desta forma, ele pode ser narrado em primeira pessoa e é uma das formas narrativas que mais se aproxima do que convencionamos chamar de 'real'. Tais escritos buscam na testemunha ou no sobrevivente o respaldo para os acontecimentos narrados (CUNHA, 2012, p. 117). Tratando especificamente do campo jornalístico, as narrativas aqui classificadas se centram na personagem que narra, de forma que 
O enquadramento é marcado pelo lugar de fala do jornalista, o autor da narrativa. Esse lugar é exterior e anterior, é o ponto de onde emanam as decisões do autor. É como autor, e não como narrador, que o jornalista delimita o enquadramento dos fatos. O lugar de fala é ideológico (CUNHA, 2012, p. 119).

Ao mesmo tempo em que o autor faz a opção pelo enquadramento, baseado em seu lugar de fala e o qual se localiza exterior ao texto, ele também opta por uma focalização, sendo esta uma forma de o olhar do narrador ser posicionado no interior do texto, quer de forma implícita, quer de forma explícita. Nos termos de Cunha (2012), a focalização narrativa pode ser de três tipos: parcial interna, parcial externa ou total:

O primeiro ponto é a perspectiva de uma só personagem ou, variando durante a narrativa, também de outras - um ponto em que, embora o narrador saiba mais que a personagem, conta apenas o que ela conhece. $\mathrm{O}$ segundo ponto apresenta somente as ações das personagens, sem que sejam conhecidos seus pensamentos e sentimentos - um ponto que produz o efeito da neutralidade e objetividade tão perseguido nos textos jornalísticos. $\mathrm{O}$ terceiro ponto é a focalização total, onde os eventos narrativos são vistos por um narrador que sabe de tudo, é onisciente, sabe mais que as personagens, capta tanto suas ações como seus sentimentos e emoções - ponto em que o narrador nunca será personagem e a narração é sempre na terceira pessoa (CUNHA, 2012, p. 122).

Cunha (2012, p. 128-132) ainda aponta os traços distintivos do texto de testemunho em relação aos demais: caráter documental e informativo; enunciação a partir de lócus político; o autor desempenhando funções de narrador e protagonista; narrativa em primeira pessoa, do singular ou do plural; utilização de vozes não hegemônicas; uso de material secundário para legitimar o relato; narração de fatos não apreciados por demais gêneros; e recursos mais familiares à narrativa literária.

Mais uma vez, voltamos à relação entre os campos da História e do Jornalismo. O texto, quando escrito com a finalidade de informar sobre algo que de fato aconteceu, para além da verossimilhança, deve guardar uma quantidade maior de traços que o liguem ao mundo vivido. Assim, "a diversidade interpretativa diz respeito ao valor de realidade do acontecimento, quer dizer, ao seu potencial de descrição do real-histórico de uma ocorrência, seja esta um aspecto miúdo do cotidiano, ou um fato de grandes proporções sociais" (SODRÉ, 2009, p. 142). Qualquer que seja o fato tornado acontecimento nos veículos de comunicação, fará parte da memória social daquele grupo e, por conseguinte, terá impacto sobre a construção de sua identidade. 
Nos termos de Quéré (2005), um acontecimento é uma ocorrência desencadeadora de sentidos. Só podemos acessar os significados de um determinado contexto, na medida em que um acontecimento, devidamente percebido e nomeado, ali irrompe e nos faz perceber as mudanças que estavam em curso, assim como nos leva a fazer previsões acerca do futuro. $\mathrm{O}$ acontecimento gera informações e anuncia o novo (FRANÇA, 2012). Contudo,

[...] o verdadeiro acontecimento não é unicamente da ordem do que ocorre, do que se passa ou se produz, mas também do que acontece a alguém. Se ele acontece a alguém, isso quer dizer que é suportado por alguém. Feliz ou infelizmente. Quer dizer que ele afecta alguém, de uma maneira ou de outra, e que suscita reacções e respostas mais ou menos apropriadas (QUÉRÉ, 2005, p. 61).

Neste sentido, os conceitos de testemunho e de acontecimento se entrecruzam. Aquilo que acontece a alguém pode ser presenciado e, em um segundo momento, transcrito em narrativa: assume caráter testemunhal. Outra possibilidade de abordagem acerca do assunto nos remete à relação do acontecimento com os textos de cunho jornalístico. Um fato, algo que faz parte do âmbito tangível do real, passa à categoria de acontecimento, mais especificamente de acontecimento jornalístico, quando publicado em meios comunicacionais (SODRÉ, 2009), uma vez que se toma conhecimento de suas mais variadas facetas a partir daqueles veículos. Sodré (2009) desenvolve o conceito de acontecimento jornalístico, o qual estaria inserido nos preâmbulos da Teoria do Acontecimento: “[...] o que chamamos de acontecimento jornalístico é um fato marcado, portanto, mais determinado para o sistema da informação pública do que outros existentes, tidos como não marcados para a formação de um conhecimento sobre a cotidianidade urbana" (SODRÉ, 2009, p. 75), onde tal marcação pode ser lida como os valores de noticiabilidade.

Se considerarmos uma narrativa que não se atém aos valores de noticiabilidade, não trata de algo que tenha sido percebido e tenha influenciado a vida de um grupo de indivíduos, estamos diante de uma narrativa que preza por esta outra possibilidade de entendimento do acontecimento. Uma narrativa, como as de Realidade, que se propõe a contar a estória de uma personagem, que percebe nele o caráter testemunhal e que entende sua perspectiva de vida enquanto acontecimento, dá vida a narrativas que possibilitam o estabelecimento de uma identidade diferenciada. Realidade, desta forma, dá à vida de suas personagens o status de acontecimento, jornalístico. Conforme define Mouillaud, "os acontecimentos explodem na superfície da mídia sobre a qual se inscrevem como sobre uma membrana sensível. Mas põem 
em ressonância os sentidos que nela são inscritos” (2012, p. 68). A Análise da Narrativa busca, por conseguinte, adentar em tais significações.

Após esta discussão, consideramos que podemos valorar os fatos em termos de marcações sociais, culturais, econômicas, enfim, de aspectos da vida que digam respeito a determinadas parcelas da sociedade, especialmente aquelas de interesse do veículo, o público ao qual ele se dirija. Do fato ao acontecimento, são realizadas escolhas pelo veículo e pelo jornalista, narradores do texto, que estão postas na narrativa, cabendo ao analista encontrá-las e, mais que isso, dar a elas, também, um valor de significado em relação a algo maior: o contexto sociocultural no qual foi produzida e publicada. Este é o caminho que nos indica a Teoria da Narrativa em relação ao Jornalismo. Caminho que trilhamos nas próximas páginas. 
CAPÍTULO III

\section{REALIDADE E NARRATIVAS: APORTES METODOLÓGICOS}

Conforme tratamos no Capítulo II, ao narrar não temos conhecimento integral acerca da relação que as palavras que escolhemos para compor nossa narrativa estabeleceram com o contexto no qual estamos, historicamente, inseridos. O significado do texto é uma relação instaurada naquele momento, a partir da forma como é tornado público e dos termos que ali estão encadeados. Um mesmo texto, assim, pode assumir significados distintos, dependendo de quem o lê ou em que situação o mesmo é lido.

A principal diferença entre as análises Estrutural e Crítica da Narrativa está na importância dada ao ambiente sociocultural no qual o texto esteja inserido. Enquanto a Análise Estrutural (e formalista) se volta para a estrutura linguística, buscando ali as relações denunciadas pelo texto, a Análise Crítica parte do texto, do que está explícito, do primeiro significante, para entender as relações estabelecidas no ambiente externo ao visível do texto. Nos termos de Motta,

[...] a análise [crítica] da narrativa que sugiro serve não apenas para observar a configuração de uma intriga e suas nuances, mas principalmente para compreender os valores canônicos de uma cultura em ação, para estudar a criação interlocutiva de significados, a construção e instituição simbólica da realidade (MOTTA, 2013, p. 123).

Realidade esta que, destacamos, cria-se em nosso imaginário exclusivamente a partir daquilo que vivenciamos. Nossa curiosidade nos impulsiona a buscar por aquilo que incomoda, ao mesmo tempo em que somente podemos conhecer algo a partir da vivência. Raymond Williams já nos alertava para o significado de cultura como uma experiência vivida:

Em verdade, ao reconhecimento de que existe um corpo individualizado de atividades morais e intelectuais que se constituem como um tribunal de 
apelação humana, ideias presentes nos significados iniciais da palavra cultura, vem associar-se e deste modo mudá-las a afirmação crescente de um novo modo de vida; todo um modo de vida que não é apenas maneira de encarar a totalidade, mas ainda maneira de interpretar toda a experiência comum e, à luz dessa interpretação, mudá-la. Cultura significava um estado ou um hábito mental ou, ainda, um corpo de atividades intelectuais e morais; agora, significa também todo um modo de vida (WILLIAMS, 1969, p. 20, grifo do autor).

A vivência, por sua vez, está dividida em dois graus: o primário, no qual percebemos algo, e o secundário, traduzido no ato de reflexão que leva ao conhecimento (MOTTA, 2013, p. 126). Nestes termos, destacamos que a Análise Crítica da Narrativa, pela qual optamos neste trabalho, não busca observar o fato histórico que se encontra externo ao texto, mas antes disto busca no discurso narrativo enquanto, este sim, fato histórico, elementos que tragam ao analista a possibilidade de, despido de opções sociopolíticas, tratar de disputas de poder e demais negociações que se encontrem externas ao texto (MOTTA, 2013, p. 130).

\subsection{As três etapas de observação: os planos de análise da narrativa}

Chegamos, assim, ao ponto em que a Análise Crítica da Narrativa entende que o discurso narrativo está dividido em três instâncias de significação, as quais estão interligadas no interior do texto e que só devem ser separadas para efeito de análise e apresentação. São elas: a) plano da expressão, b) plano da estória e c) plano da metanarrativa. O primeiro vem expresso na linguagem ou discurso; o segundo trata de conteúdo, enredo, personagens e intrigas $^{31}$; ao passo que o terceiro engloba o tema de fundo referente ao texto, os significados que dele emergem.

Independentemente dos elementos utilizados pelo narrador para a construção do texto enunciado, quer sejam visuais ou sonoros, verbais ou não verbais etc., é no plano da expressão, ou seja, na linguagem em si, que o discurso é construído: a retórica utilizada pelo autor no texto imprime naquele produto efeitos de sentido, dramáticos, que levam a um efeito pretendido, consciente ou inconscientemente. As escolhas utilizadas tendo como finalidade a construção dos efeitos de real levam ao estabelecimento dos efeitos de sentido, em uma leitura mais aprofundada dos significados gerados pela narrativa, estando os últimos relacionados aos significados encontrados no terceiro dos planos, conforme discutiremos mais a frente.

\footnotetext{
${ }^{31}$ De acordo com o Dicionário de Teoria da Narrativa, “[...] a intriga corresponde a um plano de organização macroestrutural do texto narrativo e caracteriza-se pela apresentação dos eventos segundo determinadas estratégias discursivas [...]" (REIS; LOPES, 1988, p. 211-212, grifo do autor).
} 
A partir da análise da linguagem utilizada na superfície do texto, encontramos elementos que criam o clima e dão o ritmo da estória. É no "plano do discurso propriamente dito, ou do modo como o narrador dá a conhecer ao leitor a realidade que quer evocar, que vai plasmar a estória" (MOTTA, 2013, p. 136). A linguagem utilizada para a elaboração da narrativa nos permite acessar o modo como a representação do real foi construída pelo narrador.

Outro elemento de análise que prezamos, a fim de nos aproximarmos da forma como a reportagem nos é apresentada, é a diagramação da mesma, incorporando fotografias e títulos, o que configura uma linguagem multimodal. Assim, considerando-se todos os elementos informacionais apresentados até aqui, atuamos no âmbito do sistema representacional do qual nos fala Hall (1997):

A representação conecta o significado e a linguagem à cultura. Representação é a parte essencial do processo pelo qual o significado é produzido e compartilhado entre membros de uma cultura. Este processo envolve o uso da linguagem, signos e imagens, que representam coisas (HALL, 1997, p. 15).

Numa segunda etapa, mais aprofundada em relação à primeira aproximação, chegamos ao plano da estória. Aqui são observadas as projeções, no âmbito mental, tornadas possíveis a partir da seleção de palavras, termos e conceitos encontrados na primeira instância, na superfície do texto. Assim, mergulhamos junto à significação do objeto em análise, partindo da representação. Como descreve Motta, em uma leitura que conjuga esta esfera de análise com os demais componentes do discurso,

Este é o plano virtual da significação, em que uma realidade referente é evocada pelo texto narrativo através de sequências de ações cronológicas e causais desempenhadas por personagens, estruturando uma intriga (enredo ou trama). É o plano de conteúdo da estória propriamente dito, ou plano da diegese (universo da significação), do como se, plano dos mundos possíveis da ficção, embora ocorra igualmente, com grau e dimensões diferentes, nas narrativas fáticas (MOTTA, 2013, p. 137, grifo do autor).

Já o terceiro mergulho a ser realizado rumo à significação do texto, a análise do plano da metanarrativa, é o que atinge a estrutura mais profunda e abstrata da narrativa, construindo imaginários culturais. É neste plano que se dá a realização da fábula, onde os motivos de fundo de caráter ético e moral passam a integrar o texto de uma perspectiva pré-textual, de 
certo modo antropológica (MOTTA, 2013, p. 138). Chegamos, assim, ao valor de significado daquelas parcelas que compõem o contexto no qual a narrativa se constrói:

Um conceito que explica como o signo trabalha é o de mito. Um mito é uma estória ou narrativa pela qual uma cultura explica ou compreende algum aspecto da realidade ou da natureza. O mito é o significado cultural que é ativado pelo signo, mas que pré-existe ao signo (BARTHES, 2013, p. 143).

Assim, estamos diante de narrativas que são realizadas da seguinte forma: em um primeiro momento, há a escolha, consciente ou inconsciente, das palavras que vão compor o texto. Esta seleção já nos dá indícios acerca da intencionalidade, mesmo que não explicitada, do narrador. Em uma segunda leitura, ampliando o nosso horizonte, chegamos à composição das personagens e dos conflitos, passando pelo estabelecimento do clima e do ambiente, por exemplo. Neste ponto, há certa aproximação entre os textos reais e ficcionais, posto que os elementos sejam, grosso modo, os mesmos.

No terceiro mergulho que realizamos junto à construção dos significados, olhamos para aqueles elementos que constituem o efeito de real, referentes que localizam o leitor na narrativa, a fim de transmutá-los em efeitos de sentido. No entanto, os significados que ficam da narrativa estão para além do texto. Podemos nos utilizar do levantamento histórico e dos efeitos construídos na superfície do texto a fim de reconstruirmos os significados culturais atrelados à narrativa.

Destacamos, contudo, que não há, necessariamente, uma intencionalidade do autor, ao dar voz ao narrador, de elaborar uma narrativa que faça aflorar determinados significados. Por estar submerso naquele momento histórico, vivenciando determinadas relações e sofrendo influência de outros sujeitos, as narrativas se tornam, por consequência, uma construção que nos permite adentrar rumo aos significados culturais daquele momento histórico, tendo como ponto de partida as personagens e grupos culturais escolhidos como mote para o desenvolvimento da narrativa.

Vejamos mais detidamente, no próximo tópico, as relações que são instituídas entre os textos cujas bases estão estabelecidas em eventos que de fato ocorreram, foram vivenciados pelas personagens, e aqueles que existem apenas no plano da narrativa escrita. Entre o fictício e o factual encontramos os elementos estruturais que tornam todas as estórias passíveis de existência. 


\subsection{Elementos construtores do texto: entre o fictício e o factual}

Conforme tratamos no capítulo anterior, as bases da Teoria da Narrativa estão fortemente ligadas ao contexto dos estudos literários. Alguns conceitos são utilizados de forma semelhante nas duas abordagens, a literária e a jornalística: os elementos construtores da narrativa devem ser dispostos de forma a destacar aspectos da história ou estória que o autor almeja serem conhecidos pelo público. Neste tópico, trataremos de tais elementos, uma vez que os utilizamos para a análise das narrativas de Realidade.

As categorias do texto narrativo o constituem e, simultaneamente, tornam possível a sua análise a partir desta mesma estrutura narrativa, visível na forma de enunciado. Gancho (1991, p. 05) subdivide o texto em cinco elementos: enredo, narrador, tempo, espaço e personagens. $\mathrm{O}$ enredo é este conjunto de fatos que compõe uma história e obedece a uma lógica interna: a verossimilhança. O texto torna-se uma relação verificável, onde cada fato tem uma causa e é responsável por uma consequência (GANCHO, 1991, p. 09-10). Desta forma, as cenas descritas em uma narrativa têm por finalidade realizar a conexão entre as personagens, em torno das quais se desenvolvem as ações, e os demais constituintes do enredo.

Já o narrador é um elemento organizador e estruturador da narrativa, tendo, portanto, uma função indispensável. Não há narrativa sem que haja um narrador. Mesmo que este não se queira identificar, ele ali estará. Toda narrativa é narrada por um ser que pode ou não estar presente, ativamente, na mesma. O narrador pode ser apreendido enquanto um intermediário entre aquilo que é narrado e o leitor ou o narratário ${ }^{32}$. Os elementos da narrativa obedecem, inevitavelmente, a uma lógica de construção narrativa que passa pelo crivo do narrador: "Sem os fatos não há história, e quem vive os fatos são os personagens, num determinado tempo e lugar. Mas para ser prosa de ficção é necessária a presença do narrador, pois é ele fundamentalmente que caracteriza a narrativa" (GANCHO, 1991, p. 09).

Advogamos, no entanto, que toda narrativa possui um narrador, mesmo aquelas que não tenham como proposta a prosa de ficção. Os textos ligados aos campos do Jornalismo e da História, por exemplo, possuem um narrador, o qual pode ser encontrado exclusivamente no âmbito da narrativa, expresso por meio das escolhas linguísticas que compõem o texto,

\footnotetext{
${ }^{32}$ De acordo com o E-Dicionário de Termos Literários, o narratário é a "entidade da narrativa a quem o narrador dirige o seu discurso. O narratário não deve ser confundido com o leitor, quer este seja o leitor virtual, isto é, o tipo ideal de leitor que o narrador tem em mente enquanto produtor do discurso, nem com o leitor ideal, isto é, o leitor que compreende tudo o que o autor pretende dizer".
} 
podendo explicitar ou não sua participação e, mesmo, existência, na forma como conduz a narrativa.

Um texto pode ser narrado de diversas maneiras, estando todas associadas ao tipo de pessoa gramatical empregada. O narrador em terceira pessoa participa da ação em caráter de observador, podendo ser onisciente ou onipresente. Ele pode ser um intruso aos acontecimentos ou se identificar parcialmente com alguma das personagens. $\mathrm{O}$ narrador em primeira pessoa, além de ser personagem da história, tem um campo de visão limitado, tornando-se testemunha da ação ou um dos protagonistas. No entanto, temos de ter em mente que o narrador não é o autor do texto, mesmo que estejamos tratando de uma autobiografia. $\mathrm{O}$ narrador é "[...] uma entidade de ficção, isto é, uma criação linguística do autor, e portanto só existe no texto" (GANCHO, 1991, p. 29).

O tempo na narrativa, por sua vez, admite ao menos cinco perspectivas de mensuração. Pode ser físico, psicológico, cronológico, histórico ou linguístico. O tempo psicológico pode ser chamado, também, de tempo vivido ou tempo de duração interior. Ele não coincide com as medidas temporais conhecidas, bem como não segue uma ordem lógica objetiva. Aí está a principal diferença entre o uso do tempo físico, determinado, e do psicológico, indeterminado:

\footnotetext{
Enquanto o tempo físico se traduz com mensurações precisas, que se baseiam em estalões unitários constantes, para o cômputo da duração, o psicológico se compõe de momentos imprecisos, que se aproximam ou tendem a fundir-se, o passado indistinto do presente, abrangendo, ao sabor de sentimentos e lembranças [...] Bem diferente é a ordem objetiva do tempo físico, que se apoia no princípio de causalidade, isto é, na conexão entre causa e efeito, como forma de sucessão regular dos eventos naturais (NUNES, 1988, p. 19, grifo do autor).
}

O tempo cronológico se diferencia do físico, segundo Nunes (1988, p. 20), em função de sua ligação com as atividades práticas. Neste aspecto, o tempo litúrgico e o tempo político, por exemplo, são expressões do tempo cronológico, uma vez que seguem calendários próprios. Por sua vez, “o tempo histórico representa a duração das formas históricas de vida, e podemos dividi-lo em intervalos curtos ou longos, ritmados por fatos diversos. Os intervalos curtos do tempo histórico se ajustam a acontecimentos singulares [...] Os intervalos longos correspondem a uma rede complexa de fatos ou a um processo" (NUNES, 1988, p. 21).

Por fim, no que tange à representação temporal na narrativa, o tempo linguístico é o tempo utilizado no discurso e depende, exclusivamente, do ponto de vista do narrador 
(NUNES, 1988, p. 22-23). Está ligado diretamente às palavras utilizadas e às personagens, de forma que

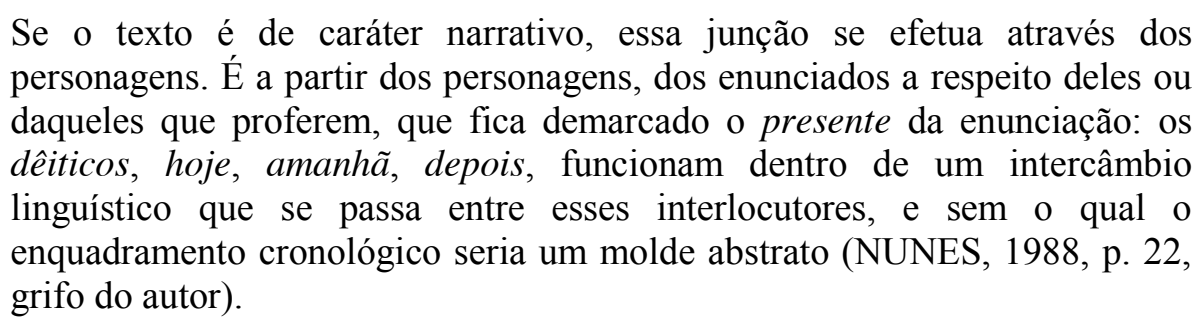

O elemento espaço, por conseguinte, refere-se ao lugar onde ocorrem as ações descritas pelo narrador. Se tratarmos de espaços configurados por meio de características subjetivas, chamamo-los de ambientes: este "é o espaço carregado de características socioeconômicas, morais, psicológicas, em que vivem os personagens. Neste sentido, ambiente é um conceito que aproxima tempo e espaço, pois é a confluência destes dois referenciais, acrescido de um clima" (GANCHO, 1991, p. 23, grifo do autor).

Quanto às personagens, definimo-las como seres ficcionais, distinto dos seres vivos que habitam a realidade - mesmo que façam referência direta a alguém -, de forma que só se pode estudar e saber algo acerca da personagem a partir da análise do próprio texto, de sua construção e formas apresentadas (BRAIT, 1998, p. 11). Há uma independência entre o sujeito tangível, ocupante de um lugar no espaço, e aquele que ocupa determina função em uma narrativa. No entanto, quando temos acesso a uma narrativa e identificamos nela a presença de uma personagem da qual temos consciência de sua existência, delegamos ao texto mais um elemento que aponta para a veracidade do fato. Construímos, no nosso imaginário, imagens que se ligam àquelas que já possuímos de determinada personagem. $\mathrm{O}$ estatuto de real do texto passa pela descrição e pela função da personagem.

Neste sentido, vislumbramos na observação apurada da composição da personagem uma possibilidade de entendermos as escolhas editoriais realizadas pela revista Realidade no momento de construir reportagens com temáticas e personagens que representam um contraponto às ideias que estavam sendo propagandeadas pelo governo militar. Vimos aqui uma possibilidade de fazermos alguns apontamentos sobre personagens que representam determinados brasileiros naquele momento histórico e cultural da ditadura, personagens estas que, por sua condição de vida, não tinham espaço em outros veículos midiáticos. Vejamos com mais detalhes as características das personagens no próximo tópico. 


\subsection{A personagem enquanto construção narrativa}

As primeiras reflexões, de que se tem conhecimento, acerca do uso das personagens em narrativas foram realizadas por Aristóteles. Em seu texto intitulado Poética, provavelmente publicada entre os anos 335 a.C. e 323 a.C., o filósofo grego parte da conceituação de poesia - lírica, épica e dramática - a fim de discutir o conceito de personagem e sua função na literatura, sendo um marco para os estudos literários.

O conceito de mimesis trata justamente da semelhança entre a personagem e a pessoa, entre o ser fictício e o real. Apesar de o termo já ter sido traduzido como imitação do real, na contemporaneidade se defende que “[...] Aristóteles estava preocupado não só com aquilo que é 'imitado' ou 'refletido' num poema, mas também com a própria maneira de ser do poema e com os meios utilizados pelo poeta para a elaboração de sua obra" (BRAIT, 1998, p. 29). Tal esclarecimento aponta para duas constatações acerca da personagem para Aristóteles: 1) ela é um reflexo da pessoa real, mas, também, 2) uma "[...] construção, cuja existência obedece às leis particulares que regem o texto" (BRAIT, 1998, p. 29). A narrativa poética, assim, não reproduz a realidade, mas sim compõe novas possibilidades de mundo.

A leitura acerca do papel da personagem começa a se modificar a partir do século XVIII. Neste momento, ela é tida como uma representação psicológica do seu criador: “[...] os seres fictícios não mais são vistos como imitação do mundo exterior, mas como projeção da maneira de ser do escritor" (BRAIT, 1998, p. 38). No entanto, a personagem continua tendo traços humanos e sendo equiparada ao existente no mundo vivido.

No decorrer do século XX, a partir da publicação da obra de György Lukács, Teoria do Romance (1920), a narrativa passa a ser conceituada enquanto confronto entre um herói problemático e o conformismo e as convenções do mundo, numa estreita relação entre o romance e o mundo burguês (BRAIT, 1998, p. 39).

No final da década de 1920, Vladimir Propp publica a primeira versão da Morfologia do Conto Maravilhoso (1928), livro no qual se dedica a analisar a estrutura dos contos russos. Neste trabalho, Propp atribui funções às personagens, as quais se repetiriam ao longo de todas as narrativas. A função da personagem é a ação por ela realizada, definida a partir de sua significação para o desenrolar da intriga (PROPP, 1970, p. 31).

Além disso, Propp (1970, p. 86) também observa a utilização de um sistema de informações a fim de tornar as funções percebidas dentro do próprio conto, pelas demais personagens: mesmo as funções sendo identificadas como elementos fundamentais para o 
conto maravilhoso, esses demais elementos possibilitam que a estória se desenvolva, de forma lógica. Tratando especificamente acerca da divisão das funções entre as personagens de um conto, Propp (1970) os agrupa em esferas de ação, sendo elas: agressor, doador, auxiliar, princesa, expeditor, herói e falso herói.

Umberto Eco (1973), por sua vez, desenvolve uma análise sobre as personagens e a construção da narrativa em torno da famosa personagem de Ian Fleming, James Bond. Para tanto, utiliza pressupostos teóricos da Análise Estrutural da Narrativa. Debruçando-se sobre os livros que têm na figura de Bond sua personagem principal, Eco elabora esquemas que tratam da estrutura dos textos, a qual estaria sempre, segundo o autor, limitada por tais variantes. Vejamos como são compostas estas divisões:

Os romances de Fleming parecem construídos sobre uma série de oposições fixas que permitem um número limitado de modificações e de interações. Estes pares constituem invariantes ao redor das quais gravitam os pares menores que constituem, de um romance para outro, variantes daqueles (ECO, 1973, p. 139).

Os pares aos quais Eco faz referência tratam tanto de funções das personagens ('Bond - O Mau' ou 'O Mundo Livre - A União Soviética'), como de momentos decisivos para a narrativa ('Amor - Morte' ou 'Risco - Programação'). Ao todo, o autor identifica quatorze pares e destaca que, por mais que eles pareçam vagos ou simplistas, na realidade seriam uma forma eficaz de descrever o que ele chama de 'achados narrativos' de Fleming (ECO, 1973, p. 140).

Após a análise de dez dos romances do autor, Eco descreve as características que rodeiam algumas das personagens principais. A seguir, um excerto no qual o autor define o antagonista nas narrativas:

O Mau vê o dia em uma zona ética que vai da Europa Central aos países eslavos e à bacia do Mediterrâneo. É habitualmente de sangue mestiço e suas origens complexas e obscuras. É assexuado ou homossexual; em todo caso, não é sexualmente normal. Dotado de qualidades excepcionais de invenção e de organização, ele empreendeu por sua própria conta uma atividade considerável que lhe permite juntar uma imensa fortuna, graças à qual trabalha em favor da Rússia (ECO, 1973, p. 145).

No tocante ao campo do jornalismo, Mesquita defende que a fronteira entre ficção jornalística, jornalismo ficcionado e jornalismo factual é imprecisa e muitas vezes os três coexistem, sobrepondo-se (MESQUITA, 2004, p. 130). Contudo, nesses casos teríamos o que 
o autor chama de 'personagem jornalística', uma das vertentes estruturadoras da narrativa factual.

Desta forma, a personagem é o ser ficcional ${ }^{33}$ responsável pelo desenrolar do enredo. De acordo com Gancho (1991, p. 14), mesmo que seja inspirada em uma pessoa dita real, aquela personagem será sempre uma invenção, uma construção literária, exclusivamente narrativa. Tal definição se aplica, também, aos textos de fundo jornalístico. Segundo o Dicionário enciclopédico das ciências da linguagem,

Olvida-se então que o problema da personagem é antes de tudo linguístico, que ela não existe fora das palavras, que é 'um ser de papel'. Entretanto, recusar toda relação entre personagem e pessoa seria absurdo: as personagens representam pessoas, segundo modalidades próprias à ficção (DUCROT; TODOROV, 2001, p. 209-210, grifo do autor).

As personagens de reportagens são, presumivelmente, baseadas em pessoas que existem no plano do real, com as quais o jornalista pode ter estabelecido algum contato, mas devemos ter claro que elas são, invariavelmente, construções, representações. A relação que elas possuem com o real é uma das vertentes contratualistas que detêm.

Para que a construção seja efetivada, é necessário que o autor realize uma seleção de características a serem descritas, falas a serem destacadas e transcritas e situações a serem apontadas no plano textual. Tudo o que podemos saber acerca da personagem devemos buscar na própria estrutura do texto, identificando nele a maneira como o autor se utilizou dos elementos narrativos para dar forma às suas criaturas. Acerca do campo de construções de narrativas jornalísticas, Mesquita destaca o papel do jornalista enquanto investigador, a fim de compor as personagens, numa comparação entre aquele e o trabalho realizado pelo escritor de ficção. Ali,

[...] o escritor é o senhor absoluto da personagem criada, enquanto o historiador ou jornalista se referem a alguém que tem existência no "real". A personagem jornalística reflecte, além da elaboração criativa, o trabalho de observação, documentação, inquérito e interpretação desenvolvidos pelo jornalista, a fim de reunir os elementos relativos ao "referente objetivo" (MESQUITA, 2004, p. 132).

\footnotetext{
${ }^{33}$ Segundo o Dicionário de Teoria da Narrativa, a ficcionalidade pode ser entendida do ponto de vista da intencionalidade, residindo nas colocações textuais que nos permitem perceber quando um texto é ou não uma obra de ficção, podendo aqui haver uma dimensão contratualista na relação entre o autor e o leitor (REIS; LOPES, 1988, p. 43-44).
} 
Ao lermos um texto jornalístico, percebemos as opções linguístico-narrativas utilizadas pelo autor. Entender estas escolhas nos dá indícios tanto do que o jornalista nos quis comunicar, como também acerca da intencionalidade do veículo ao qual ele está vinculado. Além disso, debruçarmo-nos sobre a personagem torna possível fazer assertivas sobre aquele ambiente histórico, cultural e social. Sobretudo, a autonomia possuída pelo jornalista no momento de escolha dos elementos a serem narrados como construtores do real torna o jornalista responsável pelas personagens e estereótipos que estão em construção naquele momento histórico (MESQUITA, 2004, p. 135).

Voltando à construção linguística das personagens, deparamo-nos com as funções exercidas por tais figuras no interior da narrativa. De acordo com o papel que desempenha no enredo, eles podem ser protagonistas, antagonistas ou personagens secundários, figurantes (GANCHO, 1991, p. 14-16). Quanto às descrições física e psicológica, podem ser planos ou redondos. Os primeiros são aqueles “[...] caracterizados com um número pequeno de atributos, que os identifica facilmente perante o leitor; de um modo geral são personagens pouco complexos" (GANCHO, 1991, p. 16). Os mesmos podem ser caricaturas ou tipos. Já os personagens redondos são aqueles mais complexos, dispondo de uma variedade maior de características: podem ser físicas, psicológicas, sociais, ideológicas ou morais (GANCHO, 1991, p. 18).

A descrição física passa pelas características corporais das personagens; a psicológica trata da personalidade e do estado de espírito; já a social indica desde a classificação social até a profissão e as atividades desenvolvidas; a ideológica se refere ao modo de pensar, indo de opções políticas até a filosofia de vida, por exemplo; e a moral se relaciona com um julgamento, considerando o ponto de vista do narrador (GANCHO, 1991, p. 18). A autora destaca que uma personagem pode se encaixar em mais de uma dessas classificações, dependendo de quem a esteja julgando, ou mesmo se esta ação for desenvolvida pelo narrador ou pelo leitor.

Entendendo o texto como um produto linguístico, no qual as personagens se situam no enredo e no ambiente, "[...] muitas vezes tomamos por realidade o que é apenas linguagem (e há quem afirme que a linguagem e a vida são a mesma coisa), a personagem não encontra espaço na dicotomia ser reproduzido / ser inventado. Ela percorre as dobras e o viés dessa relação e aí situa a sua existência” (BRAIT, 1998, p. 12). Neste sentido, quando lemos um texto jornalístico não estamos tendo contato com uma determinada personagem, mas sim percebendo naquelas narrativas as opções linguísticas e narrativas utilizadas pelo autor para 
descrever o ser, essencialmente, ficcional. Debruçar-nos sobre a personagem torna possível fazer assertivas sobre aquele momento/ambiente histórico, cultural e social. Todas as informações às quais acessamos, chegam-nos por meio do narrador. Assim, chegamos ao papel de tal elemento para a percepção que temos da narrativa.

\subsection{O narrador enquanto condutor da narrativa: a presença do repórter no texto}

Os conceitos de autor e narrador de um texto não podem ser confundidos, conforme alertamos anteriormente. Os dois termos referem-se a instâncias distintas da construção de uma narrativa. O jornalista, sujeito pertencente ao campo do real, é o autor do texto jornalístico. Assina-o. Identifica-se enquanto aquele que esteve junto ao assunto, apreendeu-o e então transpõe para palavras aquilo que vivenciou, mesmo que por meio de fontes. A experiência, portanto, diferencia-se daquela defendida por Benjamin, mas segue existindo, reconfigurada em termos das novas relações estabelecidas na atualidade.

Ao narrador, por sua vez, cabe a função de condução da narrativa, internamente ao texto. O narrador, portanto, existe exclusivamente no campo linguístico, assim como as personagens. Não podemos considerar que as assertivas presentes em uma narrativa sejam, obrigatoriamente, a opinião do autor. O autor, quer seja ele de um texto fíctício, quer factual, compõe o narrador, assim como compõe as demais personagens. Contudo, o narrador possui diversas nuances que serão as responsáveis por enformar o caráter narrativo: os tempos verbais utilizados, os fluxos de consciência transcritos e mesmo as opiniões explicitadas no texto nos dão acesso às características que são inerentes ao narrador.

Tudo o que nós, enquanto leitores, observamos do acontecimento só o é possível em função do crivo realizado pelo narrador. Ele é o elemento narrativo que possibilita o desenvolver dos fatos e das ações. O narrador, contando uma estória, permite-nos ver aquilo que ele intenciona que seja visto. É esse ajustamento interno da narrativa que constrói significados. Os elementos que compõem o efeito de real nos são apresentados por meio do narrador. Os efeitos de real, consequentemente, convertem-se em efeitos de sentido a partir da leitura que deles é realizada.

A fim de diferenciarmos os dois sujeitos que trabalham, conjuntamente, para a narrativa de uma determinada estória, temos de caracterizar o sujeito do enunciado e o da enunciação. O narrador é o sujeito do enunciado, ao passo que o autor é o sujeito da enunciação: "o enunciado, as frases que constituem a história, é o fato narrado (fazendo 
referência a um universo mais familiar para o campo da comunicação), e a enunciação é o ato de narrar, processo no qual se tece a história" (RESENDE, 2002, p. 56). O sujeito que narra as ações tem a possibilidade de se construir e construir às demais personagens, por meio do enunciado.

Mesmo não podendo estabelecer um grau de equidade entre os dois sujeitos, percebemos que o autor deixa marcas no texto, estando estas ligadas ao arcabouço de experiências que o mesmo traz junto de si. Não há como desvencilhar, completamente, os dois sujeitos. Eles se compõem mutuamente. Nos termos de Resende,

Ao tecer uma narrativa, literária ou não, o sujeito/autor não se desvencilha de suas próprias condições, sejam elas culturais, temporais, espaciais, dentre outras várias. No acúmulo de frases que qualquer narrativa apresenta, o texto se faz marcado pelo olhar e pelas mãos de quem o teceu. Essas marcas, certamente, são tanto de ordem subjetiva como objetiva, o que significa dizer que em qualquer texto há que se considerar desde os aspectos que o determinam $[\ldots]$ até aqueles que, no ato próprio da escritura, o redefinem [...] (RESENDE, 2002, p. 65-66).

Buscamos, portanto, entender o lugar deste narrador em meio às narrativas de Realidade. Consideremos, em primeiro lugar, que uma parcela significativa daqueles jornalistas que compunham a revista comungava dos ideais políticos da esquerda. Esta é uma informação que se faz componente do arcabouço de 'condições' que envolvem o sujeito. Portanto, há a possibilidade dos ideais políticos dos autores serem apreendido nas narrativas, o que nos leva a optar pelo percurso realizado pelo narrador como uma das categorias de análise deste trabalho.

Estamos diante, nos termos de Resende (2002), do que o autor conceitua como sendo o narrador-jornalista, um sujeito que deixa que o seu 'olhar' faça parte da narrativa, o que o faz por meio da liberdade que dá às suas personagens, deixando-as falar, fazendo-as compreendidas. O narrador-jornalista permite a construção de uma narrativa que se faz rica em detalhes, faz-se completa em termos de informações, ao mesmo tempo em que aproxima o leitor dos aspectos ali narrador. Este tipo de narrador, o qual pode emergir da apuração jornalística, dá às personagens o direito de tratarem de si mesmos. $\mathrm{O}$ olhar do narrador, portanto, nos faz ver uma vertente outra da estória, regrada a partir das memórias daqueles que vivenciaram os fatos. 


\subsection{A metanarrativa e a criação de sentidos: o mergulho na narrativa}

Ao nos depararmos com os dois primeiros planos de análise da narrativa - plano da expressão e plano da estória -, percebemos as nuances que estão atreladas às escolhas textuais realizadas pelo narrador-jornalista. Ao conjugarmos a análise do momento histórico com as informações trazidas pelo narrador à narrativa, deparamo-nos com a metanarrativa, o aspecto mais profundo e, por conseguinte, detentor de significados.

Ao considerarmos que os autores não se podem despir dos aspectos que definem a sua história de vida, fazemos o mesmo com a narrativa enquanto produto social: ela está repleta de características que a ligam ao momento presente no qual foi escrita, bem como reflete aspectos sociais, culturais, ideológicos etc. A narrativa contém significados.

Neste sentido, a nossa proposta foi buscar entender, por meio dos significados construídos pela narrativa, como se deu o mergulho dos repórteres em busca de um Brasil ainda desconhecido nas décadas de 1960 e 1970. As personagens edificadas naquelas narrativas, a utilização do narrador de uma maneira diferenciada, a opção por enredos que não tratavam, diretamente, dos problemas ocasionados pelo autoritarismo do governo, todos estes aspectos são os responsáveis, em termos sociais, pelas construções narrativas de Realidade. Buscaremos, portanto, na reflexão acerca destes aspectos, os significados que são apresentados pela revista: a metanarrativa que ela carrega.

\subsection{Realidade em análise: percurso metodológico}

Após este levantamento anterior de conceitos que se farão importantes para a nossa análise, chegamos ao percurso que percorremos junto à publicação em questão. Conforme discutimos, a revista Realidade é levada às bancas num momento de fortes mudanças culturais no Brasil e no mundo. Historicamente, os movimentos ocorridos na década de 1960 prezaram pela busca e afirmação de uma personagem essencialmente brasileira. A reportagem, carro-chefe da publicação, era tratada com esmero e atenção tanto pelos repórteres quando pelas editorias de arte e texto.

Ao folhear os noventa números publicados até setembro de 1973, momento em que ocorre a mais significativa das mudanças editoriais da revista, faz-se possível perceber a destreza na diagramação e o grande espaço ocupado pelas reportagens. Além disso, a diagramação da revista se pretendia comedida, evitando destacar-se frente às narrativas: 
No miolo, o diagrama é sóbrio. A ênfase do trabalho de design não está em peripécias diagramáticas ou tipográficas; seu foco da atenção recai sobre a relação do texto com a imagem fotográfica. O tom do projeto é seco, a ponto de, a um primeiro olhar, parecer não haver intervenção do designer (MELO, 2006, p. 153).

A leitura dos textos aponta para a vivência, ação sem a qual, segundo José Hamilton Ribeiro (2013), os trabalhos de Realidade não eram publicados. Era preciso ter certeza do que estava sendo dito. Os textos são cativantes, descrevem ambientes e personagens em detalhes, tanto objetivos quanto subjetivos. As fotografias, de caráter autoral, ligam-se ao texto de forma delicada, sem que haja a interferência de um tipo de linguagem sobre o outro. Nos termos de Melo, há uma relação sutil entre os textos em destaque nas páginas e as fotografias ali dispostas: "o discurso é comandado por fotos cuidadosamente diagramadas; o texto funciona como um balizamento sutil para as imagens alcançarem o significado pretendido" (MELO, 2006, p. 153-154). Presava-se, assim, pelo respeito mútuo entre as diversas narrativas que compunham as reportagens.

Ao perceber tais características da reportagem de Realidade, a nossa atenção foi levada ao tipo de personagem que conduz as narrativas da publicação. Na maior parte das vezes $^{34}$, deparamo-nos com personagens que representam os brasileiros que estão à margem daquela sociedade. São pessoas comuns, que trabalham exaustivamente, cotidianamente, e não sentem os reflexos do Milagre Econômico, fortemente alardeado pelo governo militar. De boiadeiros a operários, todos são tratados em moldes semelhantes pelos repórteres, apresentando as agruras de sobreviver em meio às dificuldades financeiras. Além disso, os pensamentos e diálogos próprios daqueles contextos tomam as páginas das reportagens, demonstrando a ampla utilização do fluxo de consciência enquanto recurso narrativo para composição de personagens e cenários.

O primeiro mergulho que realizamos junto aos 57 números publicados durante a segunda fase da revista, realizado por meio de uma análise sistemática, visou a perceber se o tipo de jornalismo exercido pelas equipes de jornalistas que se sucederam à equipe fundadora assemelhava-se àquele característico da primeira fase. Não buscávamos, naquele primeiro momento, selecionar o material a ser trabalhado. $\mathrm{Na}$ primeira análise percebemos que fotografias, diagramação, diálogos, temas, vivências: a maior parte das características que

\footnotetext{
${ }^{34}$ Usamos esta expressão pois em momentos de tensão entre a direção da empresa e a equipe da revista, eram publicados textos cujas personagens poderiam ser até mesmo os militares que estavam no governo da época. Nos casos dos perfis dos generais, eles eram escritos por Luís Fernando Mercadante, jornalista com "trânsito pela direita" e grande admirador de Carlos Lacerda, conforme descreve Mylton Severiano (2013, p. 34).
} 
fizeram das reportagens publicadas entre 1966 e 1968 marcos para a história do jornalismo brasileiro continuava presente nos trabalhos.

Movidos por esta 1) inquietação acerca da diferença quanto ao tratamento dado à primeira e à segunda fases de Realidade, somado ao 2) contexto histórico e social de Milagre Econômico e à 3) característica preferência da revista por personagens que fossem pessoas comuns, selecionamos em meio às reportagens publicadas naquele período, cinco narrativas ${ }^{35}$ nas quais os repórteres elegem uma determinada personagem, quer seja ela uma pessoa ou um grupo/comunidade, e contam sua história. Utilizamos como critério de escolha a diversidade de atividades, indo do ambiente rural ao industrial, bem como um corpus que demonstre a amplitude de recursos narrativos utilizada pela revista. O Quadro 1 aponta as informações gerais sobre as reportagens escolhidas.

Quadro 1 - Seleção de reportagens para análise

\begin{tabular}{|l|l|l|l|l|l|}
\hline No/Ano & \multicolumn{1}{|c|}{ Reportagem } & $\begin{array}{c}\text { Repórter de } \\
\text { texto }\end{array}$ & $\begin{array}{c}\text { Repórter } \\
\text { fotográfico }\end{array}$ & Personagem & \multicolumn{1}{|c|}{ Local } \\
\hline $37 / 1969$ & $\begin{array}{l}\text { Devagar com o } \\
\text { boi }\end{array}$ & Dirceu Soares & Chico Nelson & Peão & $\begin{array}{l}\text { Mato } \\
\text { Grosso }\end{array}$ \\
\hline $46 / 1970$ & $\begin{array}{l}\text { O canavial } \\
\text { esmaga o homem }\end{array}$ & Jorge Andrade & Jean Solari & $\begin{array}{l}\text { Trabalhador } \\
\text { de engenho }\end{array}$ & Pernambuco \\
\hline $48 / 1970$ & Povo caranguejo & $\begin{array}{l}\text { Audálio } \\
\text { Dantas }\end{array}$ & $\begin{array}{l}\text { Maureen } \\
\text { Bisilliat }\end{array}$ & $\begin{array}{l}\text { Catador de } \\
\text { caranguejo }\end{array}$ & Paraíba \\
\hline $58 / 1971$ & $\begin{array}{l}\text { Quem é o homem } \\
\text { no fundo do poço? }\end{array}$ & $\begin{array}{l}\text { Audálio } \\
\text { Dantas }\end{array}$ & Jean Solari & Operário & São Paulo \\
\hline $65 / 1971$ & $\begin{array}{l}\text { 30 dias na ilusão } \\
\text { do garimpo }\end{array}$ & José Leal & $\begin{array}{l}\text { Geraldo } \\
\text { Guimarães }\end{array}$ & Garimpeiro & Goiás \\
\hline
\end{tabular}

Fonte: Os autores, baseado em levantamento realizado em coleção particular da revista.

Tendo em vista as reportagens listadas, propusemo-nos a analisá-las buscando na construção das personagens específicas elementos que nos permitam fazer assertivas acerca das estratégias narrativas utilizadas por Realidade a fim de retratar um Brasil que, mesmo alardeando um - bem vindo - Milagre Econômico, não levava em conta os brasileiros em situações econômicas mais difíceis.

No âmbito linguístico, trabalhamos com a identificação das palavras-chave utilizadas no texto escrito, uma vez que a seleção de tais termos aponta para possíveis intencionalidades

\footnotetext{
35 Inicialmente, encontramos 32 reportagens cujas narrativas retratavam um Brasil distante e povoado por personagens marcantes e esquecidas. Em meio ao corpus encontrado durante a primeira seleção, elegemos cinco personagens/narrativas, as quais julgamos representantes dos demais, sendo possível traçarmos, a partir deles, considerações acerca das narrativas de Realidade.
} 
do autor. Expressões como miséria, fome e lama, por exemplo, sobrepujam seus significados usuais e retornam ao texto tomadas por significações abstratas que descrevem estados que podem ser mentais e não mais físicos.

Também lançamos um especial olhar à participação dos narradores nas narrativas, dando atenção à forma como eles se colocam no texto: estando a narrativa em primeira ou em terceira pessoa, buscamos os elementos textuais que apontam para a construção da personagem que é o jornalista que faz parte da revista. O texto de Realidade, assim, passa a ser um estilo de narrativa representado pelos elementos aqui elencados, utilizados e correlacionados nas reportagens.

Centramo-nos, também, na reconstrução das personagens, agrupando as informações que se encontram dissolvidas ao longo do texto. Assim, temos a possibilidade de reconstituirmos a representação daquela personagem, uma vez que a linguagem é o que usamos para nos referirmos a algo que não está, muitas vezes, na presença física do nosso interlocutor. As análises que se seguem centram-se em torno das seguintes personagens: peão de fazenda, trabalhador de engenho, catador de caranguejo, operário de fábrica e garimpeiro de diamantes.

Na reportagem Devagar com o Boi, deparamo-nos com o peão, personagem que habita o interior do Mato Grosso. São rapazes jovens e servis, cuidando do patrimônio dos donos das fazendas. Eles devem se despir de suas personalidades e assumir aquela que é esperada de um bom peão: calado, centrado, não causando confusão. A narrativa segue os peões ao longo do percurso de transferência dos bois entre duas fazendas, traçando, ao mesmo tempo, um perfil daqueles homens, do círculo social no qual estão inseridos e, mais que isso, da relação que a personagem instaura com o Brasil, fazendo ou não parte do desenvolvimento daquele país que despontava economicamente. O grupo assume o papel de fio condutor da narrativa, ao mesmo tempo em que reflete características sociais e culturais do país.

Avançando rumo aos espaços desconhecidos do país, os repórteres de Realidade vão ao interior do estado do Pernambuco em busca dos trabalhadores dos engenhos de açúcar. A personagem que dali emerge vive em meio a um mar verde formado pelas canas. Ali, naquele espaço, vê os dias passarem, observa os seus semelhantes morrendo: a personagem é um brasileiro enclausurado, sofrendo e não tendo direito a educação, saúde ou alimentação. Há um embate entre o canavial, ele mesmo uma personagem, e Gregório, um sujeito que luta, diariamente, contra aquele que lhe permite o sustento: o próprio canavial. 
A terceira narrativa que elegemos em Realidade trata de outro embate: entre o homem e o caranguejo. Povo Caranguejo dá voz a ambas as personagens, tendo o animal um espaço no qual tem suas experiências narradas. Além de se utilizar de recursos dramáticos, tais como dividir a narrativa em cenas, ora narradas com foco no homem, ora no caranguejo, o narrador humaniza o animal, aproximando-o do sofrimento que poderia, também, ser causado a um ser humano. Observamos, portanto, as implicações do uso do animal enquanto personagem, traçando paralelos entre as características do sofrimento do caranguejo e o que acontecia no Brasil, durante a parcela mais repressiva da ditadura militar. Em contrapartida, também nos aproximamos da narrativa da vida dos catadores, em meio à lama, informação que já nos posiciona frente ao tipo de narrativa que temos em mãos: a miséria e a fome imperam.

Outra possibilidade narrativa utilizada pela revista é acompanhar o cotidiano de uma família. No caso específico da reportagem Quem é o homem no fundo do poço?, os repórteres relatam a cotidianidade de Joaquim, uma personagem que divide com a família as problemáticas ligadas à manutenção da vida por meio de um salário mínimo. O homem é explorado, trabalhando muito e ganhando pouco. Dentro de casa, a mulher, Ana, faz pequenos serviços e economiza como pode. Até os filhos buscam opções de trabalho. O salário, portanto, assume ares de vilão, ao passo que os donos das fábricas, por exemplo, não são citados. Mergulhamos em uma narrativa que nos apresenta uma situação próxima, geograficamente, dos leitores (posto que Joaquim trabalhe no estado de São Paulo), mas distante socialmente. A miséria e o anonimato também povoam as cidades onde o Milagre Econômico é sentido mais fortemente. Joaquim, assim, passa a ser a personagem responsável pelo desenvolvimento do país, sendo também aquela que é explorada para tal.

Por fim, a reportagem 30 dias na ilusão do garimpo é uma narrativa em primeira pessoa. O jornalista-narrador assume o papel de garimpeiro, mergulha na cotidianidade do garimpo e dali emerge, trazendo para o texto as significações construídas naquele tipo de ambiente, no qual a violência e a morte são características que compõem o cenário: o medo impera, a violência se torna, aos poucos, uma das expressões das personagens. Ao assumir a narrativa em primeira pessoa, ao mostrar suas impressões e como o ambiente impregna nas personagens, guiando a narrativa a partir da violência, o narrador nos apresenta um Brasil que não difere especialmente daquele que era visto nos quarteis da ditadura, mas nos apresenta um país no qual a violência é aceita e cultivada, onde a ameaça é uma das principais armas e, sobretudo, uma forma de ser aceito por um grupo social. 
Quanto às fotografias, buscamos nelas elementos que reconstituam imageticamente o ambiente no qual os repórteres realizaram a reportagem, bem como traçamos um painel dos principais elementos destacados nas imagens, vislumbrando ali ganchos para a leitura realizada pelo fotógrafo acerca do ambiente e das problemáticas em questão. As fotografias funcionam como o punctum ao qual se refere Barthes (1984), o elemento subjetivo que permite a identificação do leitor com a personagem da narrativa.

Salientamos, contudo, que cada uma das narrativas foi abordada de forma independente, gerando considerações finais que as entrelaçam. De acordo com as aproximações realizadas em relação às narrativas, optamos por um determinado caminho de análise, podendo o foco estar centrado em qualquer um dos elementos aqui descritos. Passemos, nos próximos capítulos, aos significados que emergem das narrativas de Realidade. 
CAPÍTULO IV

\section{NARRATIVA I: DEVAGAR COM O BOI}

A reportagem Devagar com o Boi foi publicada na edição de número 37 da revista Realidade, indo às bancas em abril de 1969. O trabalho conta com texto de Dirceu Soares e fotografias de Chico Nelson. No sumário da edição citada encontramos a seguinte chamada: “Chova ou faça sol, os peões têm de tanger os bois, rumo às invernadas. É um ofício monótono, duro - e muitas vezes ingrato".

Ainda no sumário, observamos que a reportagem é tratada sob a insígnia de 'aventura'. Estamos diante de uma narrativa cujos editores da revista classificaram como um ato de coragem em meio ao Brasil, buscando no Pantanal a personagem em questão: o peão. Conforme tratamos anteriormente, as estórias contadas por Realidade, em geral, são guiadas por meio de uma personagem, a qual representa todo um grupo de brasileiros que se encontre em situação semelhante. Em Devagar com o Boi os repórteres se juntam a um grupo que vai guiar uma boiada ao longo de aproximadamente 300 quilômetros, no estado do Mato Grosso.

A reportagem aborda um período composto por 14 dias de jornada. A narrativa está dividida em duas partes: a primeira aponta as principais características do trabalho nas fazendas do Pantanal, ao passo que a segunda narra, cronologicamente, a jornada das personagens. O texto tem início com a saída da comitiva da fazenda, descrevendo, em termos de desafios, a transferência das reses; ele é intercalado com a história de vida das personagens e com aspectos comuns a todos aqueles que têm ligação com as fazendas do Pantanal. Como veremos, os narradores apresentam a região, as problemáticas trabalhistas ali encontradas e, sobretudo, a exploração do homem pelo homem no interior do país. A abertura da reportagem é composta por um pequeno texto que se encerra com o título atribuído à narrativa. Vejamos como o tema é apresentado ao leitor, em seu primeiro contato: 
Sob sol de rachar ou chuva forte, pelos caminhos sem fim do Pantanal, os peões vão tocando o gado. São quase uns meninos, mas já afeitos ao trabalho rude. Seu ofício é monótono, exercido com paciência desde que acordam, madrugada alta, até a noite descer: têm de acompanhar o passo da boiada, que avança lentamente, preguiçosa, para as invernadas do Sul. A ordem é uma só ao longo da jornada: DEVAGAR COM O BOI (SOARES, 1969, p. $61)$.

A partir do extrato anterior notamos que a personagem da narrativa tem que se adequar às mais diversas características físicas e ambientais do Pantanal, colocando a boiada em primeiro lugar, subjugando-se ao animal. Apesar da baixa idade, que cria a imagem de homens ainda ingênuos, esta característica da personagem é fortemente tocada pela característica do trabalho: rude. Ao mesmo tempo, o narrador nos indica que o ofício exige paciência e é monótono, repetitivo. Percebemos, assim, como as características dos trabalhadores são moldadas em função daquilo que exercem nas fazendas. Ao longo do texto, constataremos que aqueles sujeitos que melhor calam são os mais valiosos para os capatazes.

\subsection{Abertura: fotografias e representação}

Figura 4 - Devagar com o boi, Revista Realidade, no 37, abr. 1969, p. 60-61

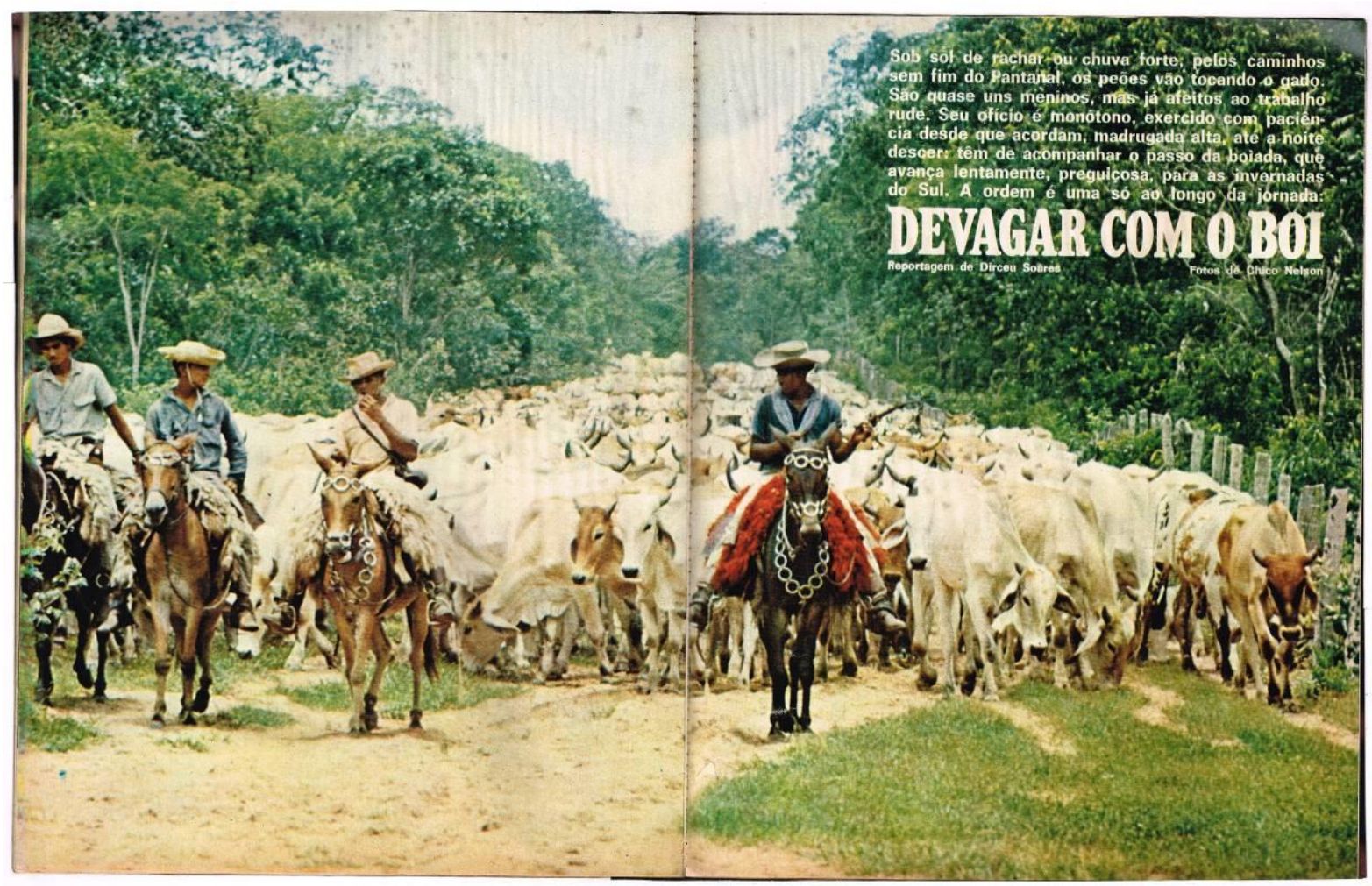

Fonte: Acervo do Grupo de Pesquisa Estudos Fotográficos (CNPq/UFCA) 
$\mathrm{Na}$ fotografia de abertura da reportagem, em página dupla (Figura 4), observamos a presença de quatro homens em frente a uma expressiva quantidade de bois. Os animais estão delimitados, fisicamente, pelas cercas que protegem as fazendas. Esta informação pode ser percebida à direita da fotografia. Ao fundo podemos identificar a vegetação típica do Pantanal, bem como o ambiente no qual se passa a narrativa: estes peões estão em campo aberto, cuidando exclusivamente dos animais - detentores de valor econômico.

As indumentárias carregadas pelos homens, conforme podemos observar, são semelhantes entre si: chapéu para proteção contra o sol, camisa de mangas, também um artifício contra a longa exposição ao sol, e calças compridas. Os homens estão atentos e, ao mesmo tempo, não parecem confortáveis com a fotografia. Nenhum deles direciona o olhar ao fotógrafo. Observam a boiada, ao passo que os bois pastam sobre as gramíneas do corredor.

O primeiro título de página da reportagem visa despertar a curiosidade do leitor: “Ao partir, os peões só pensam no prêmio". De que recompensa se está tratando? Além disso, o verbo partir remete a viagens, a uma jornada. Se os homens estão de partida e só pensam em algum prêmio, entendemos que o mesmo tenha relevante importância para a vida das personagens. O prêmio passa a ser a principal finalidade da jornada que ora se inicia.

A reportagem que temos em mãos é amplamente composta por fotografias. $\mathrm{Na}$ próxima página dupla (Figura 5), quatro imagens documentam a cotidianidade dos peões. A primeira delas - da esquerda para a direita - retrata uma das personagens da reportagem: Clarício. Naquele instante capturado, o homem trabalha no encerramento das atividades do dia, tocando os bois com um arreador. O olhar da personagem está distante, concentrado e, ao mesmo tempo, dando indícios do cansaço que o acomete.

As próximas três fotografias tratam dos instantes de descanso das personagens. $\mathrm{Na}$ primeira delas os peões se encontram em redes, acolhidos debaixo de uma estrutura de madeira. A água e a lama, no chão, denunciam a chuva que provavelmente ocorreu. Os homens pernoitam ao relento, nas imediações do local onde os bois estarão. Não há nenhuma estrutura física que os envolva: os únicos objetos no espaço são aqueles que os próprios homens carregam, tais como redes, armas e instrumentos de trabalho.

A fotografia seguinte nos apresenta o momento no qual as personagens servem-se, durante uma refeição. A posição do sujeito impossibilita que contemplemos sua identidade. É um peão que representa todos os demais do grupo. Há certa preocupação com a higiene, havendo colheres individuais para as panelas. Os braços do homem estão queimados, 
denunciando a exposição ao sol, e deixam transparecer as veias, indicativo do trabalho pesado realizado pelo mesmo.

Figura 5 - Devagar com o boi, Revista Realidade, no 37, abr. 1969, p. 62-63

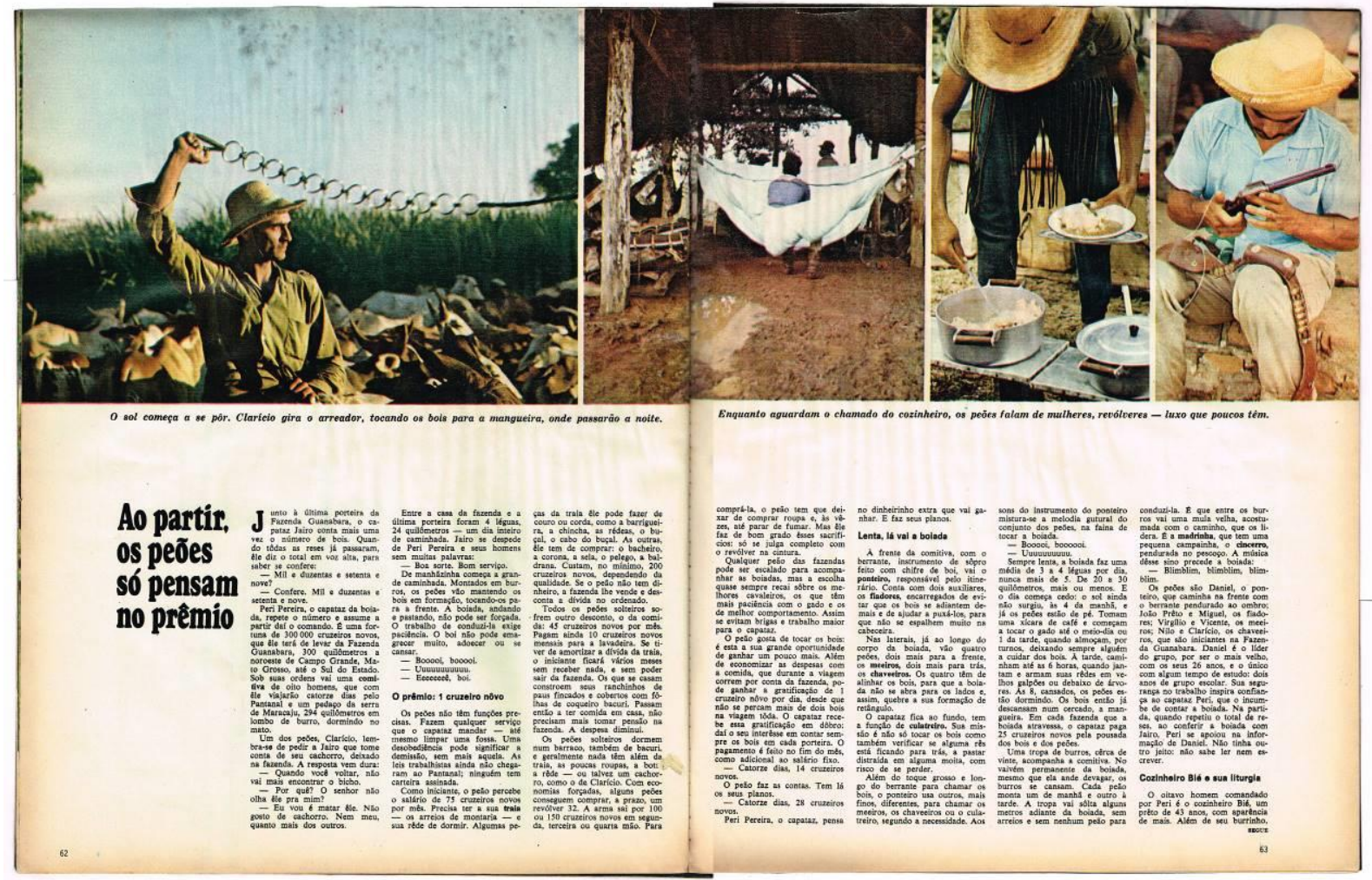

Fonte: Acervo do Grupo de Pesquisa Estudos Fotográficos (CNPq/UFCA)

Por fim, a quarta imagem da página descreve o carinho nutrido por aqueles homens para com as armas. A personagem cuida do objeto com atenção. A própria legenda classifica o revólver como um luxo, equiparando-o ao fato de poder ter uma companheira. O porte da arma remete ao poder, à proteção frente aos perigos do Pantanal. Ao mesmo tempo, pode ajudar no labor, assustando o gado em momentos de maior dispersão. Na fotografia, o homem afasta-se dos demais integrantes do grupo, limpa e cuida do revólver com esmero. Parece nutrir certa afeição pelo objeto. Como homens solitários que são, perdidos em meio aos animais, e não nutrindo relações afetivas com os demais peões, o revólver transmuta-se em companheiro, em confidente. 


\subsection{O início da jornada, a relação entre os peões}

A narrativa textual tem início com a saída dos homens e dos animais da fazenda à qual pertencem. A partida, ritualizada, envolve falas que entendemos como preestabelecidas e etapas específicas:

Junto à última porteira da Fazenda Guanabara, o capataz Jairo conta mais uma vez o número de bois. Quando todas as reses já passaram, ele diz o total em voz alta, para saber se confere:

- Mil e duzentas e setenta e nove?

- Confere. Mil e duzentas e setenta e nove (SOARES, 1969, p. 62).

A contagem dos animais é uma etapa de extrema importância para a jornada, posto que o número de reses que sai da fazenda deve ser similar ao que chega ao sul do estado, atestando a competência dos peões. A contagem terá de ser refeita todos os dias. Este valor, 1279 , vai costurar, pontuar, a narrativa. As personagens voltarão a ele com frequência. $O$ total de animais representa uma pequena fortuna, um total de 300 mil cruzeiros novos. São responsáveis pelos animais, pela fortuna do patrão, tendo de cuidar dela com habilidade.

As duas primeiras personagens a serem citadas são Jairo, o capataz da fazenda, e Peri Pereira, o capataz da boiada. Neste sentido, Peri é o responsável por uma comitiva de oito homens; ao todo, serão 14 dias de jornada, da Fazenda Guanabara (a 300 quilômetros de Campo Grande) até a região sul do estado. Duzentos e noventa e quatro quilômetros de caminhada, em lombo de burro, e dormindo ao relento.

Ao sair, os homens desvinculam-se de qualquer companhia que tenham na vida, seja ela composta pelos parentes, por uma mulher ou um animal de estimação. Clarício, um dos peões de Peri Pereira, possui um cachorro, o qual não poderá levar consigo. Pede ao capataz que cuide do mesmo. A crueza da relação estabelecida entre os peões pode ser observada no pequeno diálogo entre as duas personagens:

Um dos peões, Clarício, lembra-se de pedir a Jairo que tome conta de seu cachorro, deixado na fazenda. A resposta vem dura:

- Quando você voltar, não vai mais encontrar o bicho.

- Por quê? O senhor não olha ele pra mim?

- Eu vou é matar ele. Não gosto de cachorro. Nem meu, quanto mais dos outros (SOARES, 1969, p. 62). 
Os peões não têm o direito e nem a condição de possuírem nada. Nem ao menos o animal de estimação, o companheiro para as noites na fazenda, é aceito. O capataz, homem rude, não parece nutrir interesse no afeto, o que o torna duro e cruel. Também não mente ou omite, deixando clara a sua intenção. Não que, necessariamente, o faça, mas o propósito está posto. A personagem renega o companheirismo.

Após deixarem a casa da fazenda, levam um dia de caminhada até a porteira. A definição do espaço é dada em léguas, medida comumente utilizada naquele ambiente. As quatro léguas que separam a casa e a porteira equivalem a 24 quilômetros, aproximadamente. Conforme veremos, as medidas de tempo e espaço não são rígidas no Pantanal.

A despedida não é desempenhada por meio de muitas palavras. A fala proferida pelo capataz - 'Boa sorte. Bom serviço' - é o fecho da cena. Aqueles são peões que ali estão para cuidarem dos bens do patrão, para sofrerem no caminho em busca de um prêmio, conforme anuncia o título de página. Exige-se dos homens força e atenção, ao passo que "A boiada, andando e pastando, não pode ser forçada. $\mathrm{O}$ trabalho de conduzi-la exige paciência. $\mathrm{O}$ boi não pode emagrecer muito, adoecer ou se cansar" (SOARES, 1969, p, 62). Como podemos observar, há uma inversão de valores: os homens são tratados brutamente, ao passo que os animais devem ser tratados 'humanamente'. Os sujeitos estão a serviço da fazenda. Em contrapartida, os animais são os objetos detentores de valor na narrativa.

Em um diálogo claro com a forma narrativa do chamado New Journalism, há a transcrição dos sons emitidos pelos peões durante a lida com os bois. O narrador traz para dentro do texto, para além das imagens descritas, tanto geográficas quanto do ponto de vista das indumentárias, os sons que inundam o ambiente e, mais que isso, são instrumentos de trabalho do peão. Vejamos um exemplo: “- Booooi, booooi. - Uuuuuuuuuuu. - Eeeeeeeê, boi”. O narrador rotula tais interações do homem para com o ambiente como uma 'melodia gutural', própria dos peões. Percebemos, aqui, que os homens e os bichos estão postos, pela narrativa, em posições significativamente semelhantes, uma vez que ambos emitem sons característicos. As referências são semelhantes, criando uma relação de intertextualidade entre as duas linguagens.

\subsection{O peão e a boiada: a relação entre as personagens}

O prêmio ao qual o título de página se refere é anunciado em um intertítulo da reportagem: 'O prêmio: 1 cruzeiro novo'. Os homens nutrem um interesse significativo pela 
recompensa em questão, no entanto, agora podemos perceber o quão habituados ao pouco as personagens estão. A recompensa é mínima, o que não se coaduna com o trabalho duro que é exigido para tal.

$\mathrm{Na}$ fazenda, os homens vivem sob a névoa constante da possibilidade de serem dispensados do trabalho. São explorados, recebem pouco, vivem com o mínimo e mesmo assim estão subjugados ao perigo de, em função de uma recusa a uma ordem, serem afastados da fazenda. Nos termos da narrativa, "Os peões não têm funções precisas. Fazem qualquer serviço que o capataz mandar - até mesmo limpar uma fossa. Uma desobediência pode significar a demissão, sem mais aquela. As leis trabalhistas ainda não chegaram ao Pantanal; ninguém tem carteira assinada" (SOARES, 1969, p. 62). Em consonância com a proposta da revista, o texto mergulha no país, aponta para problemas legais que o envolvem. Neste caso, mesmo existindo leis que protejam os trabalhadores, elas não se aplicam aos peões do Pantanal. Aqueles são brasileiros não acolhidos pelos direitos que, em tese, deveriam servir a todos. Além de sofrerem com os excessos dos patrões, também não têm como buscar uma defesa justa. Submetem-se, calam-se, subjugam-se.

Quando são iniciantes, ao se ligarem a uma fazenda, os jovens devem buscar uma forma de obter a traia - os arreios de montaria - e a rede, além de algumas roupas e uma arma, seja ela um revólver ou uma faca. No entanto, como a região é carente e os homens recebem pouco no início da carreira, são obrigados, muitas vezes, a deverem ao patrão desde o momento da chegada à fazenda. O salário do peão é de 75 cruzeiros novos. As peças da traia que devem, obrigatoriamente, serem adquiridos, custam por volta de 200 cruzeiros novos. Caso não possua este valor, a fazenda venderá o material ao peão, o qual será descontado do ordenado. Além disso, caso seja solteiro, o peão ainda sofre outro desconto, de mais 45 cruzeiros novos, pela alimentação, realizada na própria fazenda. Um último gasto obrigatório é de 10 cruzeiros novos para a lavadeira.

Considerando o cenário econômico e social descrito,

Se tiver de amortizar a dívida da traia, o iniciante ficará vários meses sem receber nada, e sem poder sair da fazenda. Os que se casam constroem os seus ranchinhos de paus fincados e cobertos com folhas de coqueiro bacuri. Passam então a ter comida em casa, não precisam mais tomar pensão na fazenda. A despesa diminui (SOARES, 1969, p. 62, grifo nosso).

Conforme podemos verificar ao longo da narrativa, em especial nos trechos destacados, o homem se torna, na prática, um escravo do dono da fazenda. Não pode recusar- 
se a realizar nenhum trabalho, não recebe dinheiro, não se pode desligar daquele ambiente. $\mathrm{O}$ fazendeiro, que não aparece enquanto personagem efetivo da narrativa, pode ser identificado em função do poder que exerce sobre as ações dos homens. Por medo, eles não reagem aos problemas apontados. Pelo contrário, buscam uma forma de amenizar as dificuldades econômicas. Ao casar, ao constituir uma família, na verdade, veem ali a possibilidade de diminuição das despesas. Por meio de tal informação, podemos apreender o nível de exploração à qual os homens estão expostos: alimentar duas pessoas, em casa, custa menos que pagar para comer sozinho na fazenda.

Os bens do peão resumem-se, basicamente, àquilo que ele pode carregar. Quando ainda não são casados, vivem na fazenda. Dependem daquele espaço. Economizando aquilo que, basicamente, não recebem, os homens sonham em ter um revólver. Deixam de adquirir os demais produtos necessitados e focam na aquisição da arma. O nível de interesse que os homens têm no objeto está evidenciado na seguinte passagem:

Com economias forçadas, alguns peões conseguem comprar, a prazo, um revólver 32. A arma sai por 100 ou 150 cruzeiros novos em segunda, terceira ou quarta mão. Para comprá-la, o peão tem que deixar de comprar roupa e, às vezes, até parar de fumar. Mas ele faz de bom grado esses sacrifícios: só se julga completo com o revólver na cintura (SOARES, 1969, p. 62-63, grifo nosso).

Detendo-nos na parcela grifada do texto, podemos entender o significado do revólver não apenas para as personagens da narrativa, mas também para toda a classe de brasileiros que vive em condições semelhantes. A arma mostra-se um dos elementos que torna a personagem socialmente reconhecida enquanto peão. $\mathrm{O}$ respeito é adquirido por meio do poder que advém da arma de fogo. Um peão, assim, é medido pelos demais a partir daquilo que possui. A opção do homem por ter uma arma significa-se do ponto de vista da construção social da identidade daquelas personagens.

Três são as características dos homens que são valorizadas pelos capatazes: 1) boa montaria; 2) paciência; e 3) bom comportamento. A intenção, segundo o narrador, é evitar brigas entre os homens que ficam sob o comando do capataz. Há, assim, um padrão de características que deve ser seguido pelos trabalhadores. Baseados na capacidade que eles vão ter de assumir a fama de bons peões, maior a possibilidade de conseguirem o chamado prêmio. O poder que a personagem tem de adequar-se ao que é esperado dela, no grupo, rege as suas finanças. 
De acordo com a reportagem, os homens gostam de serem escolhidos para tocar o boi, o que salienta o valor da capacidade de a personagem formatar suas características sociais em função daquelas que são esperadas de um 'bom' peão. Ser escolhido significa economizar com as despesas mensais, uma vez que a alimentação fica por conta da fazenda durante os dias de jornada, e ainda há a possibilidade de receber o prêmio pelo bom trabalho:

[...] podem ganhar a gratificação de 1 cruzeiro novo por dia, desde que não se percam mais de dois bois na viagem toda. O capataz recebe essa gratificação em dobro: daí o interesse em contar sempre os bois em cada porteira. O pagamento é feito no fim do mês, como adicional ao salário fixo.

- Catorze dias, 14 cruzeiros novos.

O peão faz as contas. Tem lá os seus planos.

- Catorze dias, 28 cruzeiros novos.

Peri Pereira, o capataz, pensa no dinheirinho extra que vai ganhar. E faz seus planos (SOARES, 1969, p. 63, grifo nosso).

Até este ponto da narrativa, as personagens, para além do capataz, ainda não foram apresentadas. O narrador tem se interessado em apresentar as características gerais do ofício, as práticas de exploração realizadas pelo fazendeiro e as implicações de tais ações na cotidianidade dos peões. Ao tratar do prêmio, trata do peão como uma categoria geral, não dando nomes ou especificando de quem ele está falando. Todos os homens naquelas condições fazem planos quanto ao emprego da gratificação. Inclui-se, nessa condição, o capataz da boiada. Outro aspecto a ser analisado diz respeito ao ato de contar os bois a cada porteira. A informação remete para o sucesso dos trabalhadores, a cada fim de tarde. Caso o número, repetido diariamente, coincida com aquele dito por Jairo no início da jornada, há a expectativa do prêmio. A cifra é a informação que nos diz quando os homens estão tranquilos em relação ao labor. O valor, ainda, remete ao bom funcionamento interno da narrativa: não havendo problemas com a quantidade de reses, as personagens estão motivadas a trabalharem.

A próxima parte da narrativa nos apresenta as funções exercidas pelos peões quando estão tocando os bois. Há nomenclaturas específicas para cada função. O ponteiro está à frente, guiando os demais. Na sequência temos os fiadores, um de cada lado, tendo a função de auxiliar o ponteiro. Nas laterais estão posicionados os meeiros e os chaveeiros um pouco mais recuados, ambos com a função de manter a formação da boiada. Por fim, o capataz assume a função de culatreiro, cuidando para que os bois não se percam.

Os homens estão envoltos, segundo o narrador, em uma melodia específica. Para além dos sons já citados anteriormente, há ainda aquele que emana dos berrantes. O ponteiro é 
responsável por guiar a boiada e os demais peões, em função dos signos sonoros enviados. Há toda uma significação em torno dos sons. A depender do tipo de chifre utilizado para entoar o toque, a mensagem pode estar direcionada aos animais ou aos companheiros de trabalho. Assim, há a construção de um cenário rico em informações, indo desde as características visíveis até àquelas percebidas por meio do ar.

Toda a jornada segue o mesmo roteiro diário. Os homens levantam-se às $4 \mathrm{~h}$ da madrugada, tomam café e começam a tocar os bois. Aquele é o único alimento que terão até à 1h da tarde, aproximadamente, quando pararão para almoçar. Em seguida, continuam o trabalho até o cair da noite, de forma que às $20 \mathrm{~h}$ já se encontram cansados e dormem. $\mathrm{O}$ trabalho junto às boiadas implica no esgotamento físico do peão. A boiada não pode ser exigida, mas os homens levam muitas horas na condução dos animais, comem pouco e não possuem um local adequado para descansarem. A construção da personagem, por meio do narrador, leva à representação do peão enquanto sujeito explorado.

Para além das personagens e dos elementos já descritos até o momento, o narrador nos apresenta mais uma das facetas da condução dos animais:

Uma tropa de burros, cerca de vinte, acompanha a comitiva. No vaivém permanente da boiada, mesmo que ela ande devagar, os burros se cansam. Cada peão monta um de manhã e outro à tarde. A tropa vai solta alguns metros adiante da boiada, sem arreios e sem nenhum peão para conduzi-la. É que entre os burros vai uma mula velha, acostumada com o caminho, que os lidera (SOARES, 1969, p. 63).

Os burros possuem o direito de ficarem cansados, eles são permutados ao longo do dia, o que não acontece aos homens. Agora está apresentado todo o grupo, detendo-se nas funções desenvolvidas por homens e animais. É chagada a hora, portanto, de nos apresentar as personagens que vão guiar os animais ao longo dos próximos 14 dias de jornada:

Os peões são Daniel, o ponteiro, que caminha na frente com o berrante pendurado ao ombro; João Preto e Miguel, os fiadores; Virgílio e Vicente, os meeiros; Nilo e Clarício, os chaveeiros, que são iniciantes na Fazenda Guanabara. Daniel é o líder do grupo, por ser o mais velho, com os seus 26 anos, e o único com algum tempo de estudo: dois anos de grupo escolar. Sua segurança no trabalho inspira confiança ao capataz Peri, que o incumbe de contar a boiada. Na partida, quando repetiu o total de reses, ao conferir a boiada com Jairo, Peri se apoiou na informação de Daniel. Não tinha outro jeito: não sabe ler nem escrever (SOARES, 1969, p. 63, grifo nosso). 
Destacamos algumas informações referentes ao trecho citado acima. Além de, neste ponto, termos nomes ligados às funções, observamos um processo de humanização dos peões. Anteriormente tratados de forma genérica, agora observamos nomes que simbolizam as atividades exercidas. Aqueles sujeitos agora são identificados. Em uma segunda análise do trecho, temos ainda informações referentes às condições de educação e mesmo um indicativo de determinados problemas sociais que envolvem aquela parcela dos brasileiros. Daniel, sendo o mais velho dos peões, tem apenas 26 anos. Qual a idade dos demais? Sabemos que existem iniciantes entre aqueles jovens: com que idade os meninos são obrigados, cultural e socialmente, a trabalharem para ajudar no sustento da casa ou no próprio? Todas essas indagações podem surgir a partir da leitura da narrativa. Espera-se que, agora, vislumbremos as estórias de vida de cada uma das personagens, tendo acesso, por conseguinte, às problemáticas sociais que envolvem a população ligada às fazendas do Pantanal.

O último dos peões é Bié, o cozinheiro. O sujeito, segundo a narrativa, tem feições envelhecidas, parece ter mais do que os seus 43 anos. Tal característica, em geral, pode ser percebida após uma vida de sofrimento, exposta ao sol e à má alimentação. De acordo com as escolhas realizadas pelo narrador, compreendemos que o sofrimento do homem continua a se dar na atualidade da narrativa, posto que enfrente disputas de poder com os demais peões:

\footnotetext{
Além de seu burrinho, leva mais três velhas bestas de carga com os mantimentos, o vasilhame, a trempe para cozinhar e as trouxas dos peões, com suas redes e uma muda de roupa. Seu trabalho não é bem visto pelos peões, que acham esse serviço muito fácil. Difícil é dominar burros, guiar bois (SOARES, 1969, p. 63-64).
}

O cozinheiro é aquele homem que teve experiência como peão, guiando bois, mas, por possuir algum problema grave, de saúde, é redirecionado para outra função. Ela exige menos do homem, ao menos no que se refere à força física e à paciência. O prêmio, também, depende menos dele que dos demais peões. Todavia, viaja sozinho, na companhia apenas dos animais. Tem de conduzir, também com atenção, os burros que levam os pertences dos demais homens, bem como tem de organizar as refeições e cuidar para que o sofrimento dos trabalhadores seja amenizado. Mesmo assim, o trabalho dele é menosprezado pelos jovens que fazem parte do grupo. A experiência, nesse sentido, é ignorada. Os rapazes são ingênuos e imaturos, mesmo estando sujeitos a um trabalho tão rude e pesado. O modo de vida, a cultura na qual estão inseridos, não permite que os peões se sensibilizem com as demais funções realizadas junto à boiada, criando sujeitos voltados apenas para si. 
O cozinheiro é fartamente descrito na sequência da narrativa. Dada sua experiência, o narrador dedica-se a traçar um perfil físico e psicológico daquela personagem. Vejamos como se dá tal opção narrativa:

Magro, caladão, Bié às vezes diz uma brincadeira, às vezes se fecha,
impenetrável. Chega a ser amargo: mesmo suas pilhérias têm um quê de
tristeza. Muito meticuloso, faz o seu serviço como um ritual. Enquanto a
boiada avança a passo lento, ele toca sua tropa de velhas mulas, passa por
atalhos e chega umas duas horas antes ao local do almoço, já combinado
com o capataz. Montado num burrinho, vai em frente. - Burro, brrrr (SOARES, 1969, p. 64).

Bié conhece bem os caminhos a serem traçados pela boiada e pelos peões. Tem a capacidade de tomar atalhos. Contudo, é justamente a sua estória de vida que faz dele um ser amargo, triste. Não há alusões, até aqui, à família do sujeito. O tipo de vida que foi obrigado a seguir o torna impenetrável. Essas características nos fazem perceber como são as personagens com as quais estamos lidando. O clima do ambiente, portanto, é regido pela constante ameaça da redução do número de bois e pela amargura daqueles homens que seguem fazendo o trabalho rude. Como consequência, temos sujeitos vivendo em estado de constante tensão. No mais, destacamos o fato de a passagem ser encerrada, mais uma vez, por meio de um recurso utilizado pelo New Journalism: a transcrição do urro realizado pela personagem, característico do labor.

Por ser um dos mais velhos trabalhadores da fazenda, Bié tem a possibilidade de impor as suas próprias regras, ao longo do percurso que realiza. A personagem está autorizada a por em prática aquilo que julga mais higiênico e, mais que isso, punir aqueles que não sigam suas ordens. Há uma cultura do medo traduzida por meio do que Bié impõe enquanto leis, regras a serem seguidas. Vejamos a opinião das demais personagens:

Os peões fazem malabarismos para respeitar as leis do cozinheiro. Ao se servir numa panela, têm de pegar a tampa com o dedo mindinho da mão esquerda e segurar o prato com os outros dedos da mesma mão; com a mão direita, tiram a comida com as colheres colocadas dentro de cada panela. Os peões obedecem para fugir a uma punição: se for violada qualquer dessas regras, o cozinheiro está autorizado pelo capataz da boiada a comprar uma galinha, na próxima parada, e debitá-la na conta do peão transgressor. Como ninguém quer sofrer desconto no salário, todos cumprem direitinho o ritual de Bié (SOARES, 1969, p. 64). 
A personagem de Bié cria regras das quais os demais peões discordam. No entanto, como uma punição advém da transgressão, os homens submetem-se aos mandos e desmandos do cozinheiro. Não cabe a eles opinar sobre a utilidade ou o aspecto legal do autoritarismo. A publicação da reportagem, lembramos, dá-se apenas quatro meses após a promulgação do Ato Institucional $\mathrm{N}^{0}$ 5. O país vivia sob a égide da imposição de regras, das quais parte dos brasileiros discordava. A própria censura à imprensa pode ser tida como uma regra que deveria ser seguida, ou burlada, obedecendo-se ao que estava posto enquanto lei.

O cozinheiro, que possui o conhecimento empírico do trabalho como um todo, está, essencialmente, sozinho: "Vai solitário, sem ter com quem conversar, fumando de vez em quando um cigarrinho. - Burro, brrrrrr" (SOARES, 1969, p. 64). O modo característico de lidar com os animais vai se tornando uma forma de encerramento da cena, facilitando a transição para outro assunto. A narrativa cria a figura de um peão que, ao voltar ao trabalho, deixa de pensar. O sujeito tem o dever de ligar-se inteiramente ao trabalho.

A comitiva possui um peão que está iniciando naquele tipo de tarefa. O nome do garoto é Nilo. Com apenas 14 anos, o menino ainda mora com a família, mas tem que trabalhar para ajudar os pais. Deparamo-nos com uma informação que nos remete à situação das famílias naquela região. Para além das dificuldades econômicas que obrigam os jovens, quase ainda na infância, a trabalharem, eles também deixam de ter a possibilidade de acesso às escolas. Na medida em que dedicam uma quantidade considerável de tempo e esforço ao labor, impossibilitam a saída daquela situação. Nilo, chegando àquele ambiente, mantém parte da inocência da infância. Apenas observa os demais peões. $\mathrm{O}$ menino evita falar, ser notado. Tenta seguir as regras de Bié e realizar o trabalho que lhe foi imposto. Porém, é chamado ao diálogo por Miguel, que tenta compartilhar sua história:

\footnotetext{
Miguel começou mais cedo que ele [Nilo], aos doze anos, porque os pais se separaram e ele precisou trabalhar. Agora está com vinte anos, tem um jeitão alegre, muito vivo, que lhe valeu um apelido: Pula-Cedo. Miguel é magrela, nasceu na fronteira com o Paraguai. Ele conta a Nilo como foi a sua aventura:

- Naquele tempo, era muito mais difícil um guri viajar. Os outros peões costumavam fazer brincadeiras pesadas com a gente. [...] Agora não é mais assim. Os boiadeiros são mais camaradas (SOARES, 1969, p. 65).
}

Miguel parece destoar, em termos de características psicológicas, dos demais peões, uma vez que o fato de ter um 'jeito alegre' destaca-se na descrição. Apesar da pouca idade, apenas vinte anos, o rapaz já tem cerca de oito anos de experiência com o trabalho nas 
fazendas. Os rapazes são chamados a trabalhar desde que a família tenha a necessidade, tornando possível a sobrevivência. Em uma segunda leitura, mesmo relatando um curto espaço de tempo, menos de uma década, a personagem nos descreve as variações no labor que pode perceber. Os demais peões, por exemplo, não exigem mais, não realizam brincadeiras perigosas, para com aqueles que estão iniciando. Pode ter havido certa tomada de consciência acerca das necessidades que cada um enfrenta ou, numa outra possibilidade, a personagem que já é descrita enquanto alguém distante e frio vai se tornando, cada vez mais, impossibilitada de criar laços. A camaradagem, conforme descrita no texto, não se reflete no companheirismo, mas, sim, no distanciamento social dos sujeitos.

$\mathrm{Na}$ sequência das descrições das personagens, o narrador dá relevo à ingenuidade daqueles meninos. Clarício, por exemplo, tem 19 anos, é alto, claro e possui olhos azuis. Além das características físicas que o diferenciam dos demais, ele possui um 'ar ingênuo', segundo o texto. Esta ingenuidade já teve uma pequena mostra apontada no início da reportagem, quando a mesma personagem pede ao capataz que cuide de seu cachorro. A afinidade com o animal pode ser tida como um reflexo da puerilidade do rapaz, posto que a regra seja de pessoas distantes, sem afeto. Miguel, o mais brincalhão, também deixa transparecer certa inocência ao dar apelidos: chama Clarício apenas de Grandão. Alcunha tão comum entre crianças, reflete tão somente uma característica física. A pouca relação estabelecida entre aqueles que compõem o grupo não permite que uns conheçam aos outros.

A introspecção é outra característica do perfil psicológico dos peões. Virgílio e Nilo, por exemplo, são caracterizados pelo fato de serem quietos. As personagens são, inclusive, comparadas: "Virgílio é quase tão calado quanto Nilo" (SOARES, 1969, p. 65). Dada tal condição, não interagirem, permanecem em uma situação de segurança. Não são conhecidos pelos demais, não criam laços, não nutrem nenhum tipo de sentimento pelos demais integrantes do grupo. Devemos lembrar que não parece ser dada a chance de construção de laços às personagens: no momento em que não se pode nutrir nenhum tipo de sentimento nem ao menos por um animal de estimação, não se pode esperar que os homens o façam entre eles.

Outro aspecto que chama a atenção é a forma como a cor da pele de algumas das personagens se destaca frente à construção narrativa. Primeiramente, vemos um dos peões ser descrito como 'branco com olhos azuis'. Em seguida, duas outras personagens são caracterizadas pelo tom mais escuro da pele: Vicente é um 'preto bem preto', ao passo que João Augusto é conhecido como 'João Preto'. Vale destacar que o narrador revela certa 
insegurança quanto aos apelidos: Vicente tem a pele mais escura que João Preto, o que lhe parece inconsistente.

O narrador pinça aquelas características que diferenciam as personagens. Sobre João Preto, o próprio título de página (Figura 6) aponta para a relação do homem com a aparência: 'João Preto gostaria de ser mocinho de faroeste'. Segue a descrição da personagem:

Se tivesse dinheiro, compraria muita roupa bonita. [...] Alto e forte, aparenta uma saúde de cavalo de raça, na vitalidade dos seus dezenove anos. É o que mais se preocupa com a elegância: usa chapéu de feltro com abas bem largas, o revólver 32 pendurado no cinturão de balas, caindo pela coxa direita - como os mocinhos que já viu no cinema -, e um lenço grande no pescoço. [...] Durante a viagem, é o que mais se importa em tomar um banho, de vez em quando (SOARES, 1969, p. 65, grifo nosso).

O desejo da personagem revela as impossibilidades que circundam aquela profissão. João Preto necessitaria de dinheiro para ser quem ele realmente é (ou ter aquilo que realmente quer ter). $\mathrm{Na}$ impossibilidade disso, faz suas economias e vai, aos poucos, transformando-se no sonho: parecer com um mocinho de filme norte-americano. A presença do revólver, conforme já relatado em outra passagem, denuncia o esforço do homem para afirmar-se enquanto peão. A forte entrada dos produtos americanos no país dá-se na década anterior. Enquanto brigava-se por uma cultura tipicamente brasileira, a personagem, sendo ela mesma uma representação típica do brasileiro, busca transmutar-se em uma personagem estrangeira à sua cultura.

De acordo com o narrador, a indumentária de João Preto faz com que aquela personagem seja percebida em meio aos demais. Clarício, mesmo ingênuo, alfineta o modo de a outra personagem pensar a própria aparência: “- João Preto [...] é cheio de luxo" (SOARES, 1969, p. 65). Aqueles homens não possuem o direito, socialmente aceito, de quererem nada que esteja além do básico que já lhes é dedicado pelas circunstâncias. Acostumam-se com o mínimo necessário e entendem que aqueles que sonham, que querem mais, que fazem esforços em busca da mudança, estão tendo 'luxos'. Contudo, as opções realizadas pelos patrões, por aqueles que possuem, de fato, o poder, não são vistas como um luxo. Os peões não devem expor sonhos e sentimentos. 
Figura 6 - Devagar com o boi, Revista Realidade, no 37, abr. 1969, p. 64-65

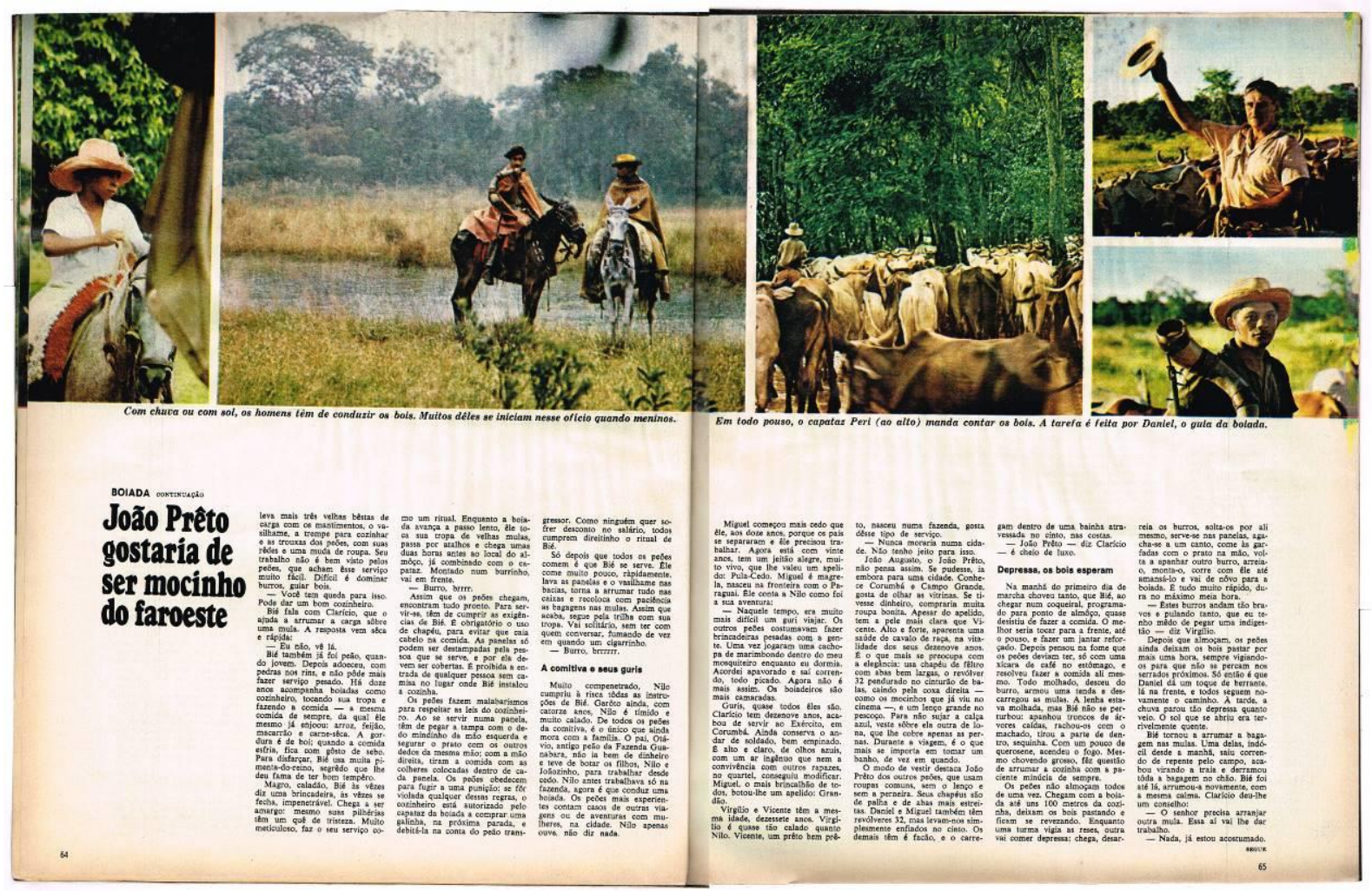

Fonte: Acervo do Grupo de Pesquisa Estudos Fotográficos (CNPq/UFCA)

Após a apresentação das personagens, podemos lançar um olhar mais detido sobre o segundo bloco de fotografias que faz parte da reportagem (Figura 6). Como no caso anterior, temos quatro fotografias, dispostas no topo da página. Na primeira delas observamos um jovem, com características físicas que indicam a baixa idade, aboiando. Segundo as informações que já possuímos, podemos concluir que este seja Nilo, o mais novo dos peões. O rapaz leva uma expressão séria. O chapéu esconde o olhar do menino. A fotografia não é posada, tendo sido capturada de um ponto distante ao retratado. No caso do pequeno Nilo, podemos perceber certa insegurança quanto ao modo de lidar com a montaria. Os braços estão mais abertos do que o esperado de uma personagem já habituada ao labor.

A segunda imagem retrata um panorama do ambiente do Pantanal. Há vegetação rasteira no primeiro plano, certa quantidade de água ao fundo e mais algumas árvores, sendo estas mais frondosas. Em meio à paisagem, dois homens estão montados em seus burros, completando a composição. Um dele, segundo podemos perceber, leva um berrante ao ombro. Assumimos, então, que este seja Daniel, o ponteiro. Ambas as personagens usam uma capa por cima da roupa, completando a indumentária. Segundo a legenda da primeira dupla de 
fotografias, "Com chuva ou com sol, os homens têm de conduzir os bois. Muitos deles se iniciam nesse ofício quando meninos", num diálogo que se efetiva com as primeiras imagens.

$\mathrm{Na}$ segunda página, três fotografias integralizam a narrativa imagética. A primeira delas demonstra o mar de bois que se forma em meio à vegetação local. Os animais ocupam praticamente todo o espaço não tomado pelas árvores. Sobressaindo-se, observamos um dos peões, atento ao caminhar da boiada. No lado direito da página, dois retratos: Peri Pereira e Daniel. Esta informação nos é trazida pela legenda. O capataz, assim, tem feições mais velhas, o que indica que ele trabalhe há mais tempo na fazenda e, por conseguinte, tenha tal função de confiança. Daniel, por sua vez, tem feições de cansaço e certo ar pueril. Contudo, esta leitura só pode ser possível a partir da informação anterior que nos foi dada, na qual os peões são descritos em função do quadro psicológico que possuem.

\subsection{O trabalho rumo às invernadas do sul}

A partir deste ponto da narrativa tem início a narração dos dias de jornada. O primeiro deles foi marcado pela chuva, a qual inundou parte do caminho. Tendo sido uniforme, atingiu também o local marcado com sendo a primeira parada do grupo, para o almoço. Chegando lá, cerca de duas horas antes, Bié cogita seguir sem parar para cozinhar. No entanto, baseado na experiência que possui, sabe que os homens estão com fome. Tomaram apenas um pouco de café. A chegada de Bié ao local é narrada como uma cena:

Todo molhado, desceu do burro, armou uma tenda, e descarregou as mulas. A lenha estava molhada, mas Bié não se perturbou: apanhou troncos de árvores caídas, rachou-os com o machado, tirou a parte de dentro, sequinha. Com um pouco de querosene, acendeu o fogo. Mesmo chovendo grosso, fez questão de arrumar a cozinha com a paciente minúcia de sempre (SOARES, 1969, p. 65).

Os anos de experiência da personagem refletem-se na forma como a mesma lida com as adversidades do ambiente e da caminhada. Além de conhecer e tomar os atalhos, Bié também consegue lidar com as chuvas que inundam o pantanal. Outro aspecto desvendado pelo trecho faz referência à meticulosidade da personagem. As leis por ele impostas são seguidas, até mesmo por ele, nas mais diversas situações.

A descrição do tempo decorrido ao longo da narrativa ganha uma dimensão que se reflete na forma como o narrador descreve a cena. No exemplo anterior, considerando-se que 
Bié possui duas horas para o desenvolvimento das atividades, as ações de montar o espaço do almoço e cozinhar são narradas compassada e gradualmente. Na passagem seguinte, onde os peões seguem para o almoço, observamos uma narrativa acelerada. Vejamos:

Enquanto uma turma vigia as reses, outra vai comer depressa; chega, desarreia os burros, solta-os por ali mesmo, serve-se nas panelas, agacha-se a um canto, come às garfadas com o prato na mão, volta a apanhar outro burro, arreia-o, monta-o, corre com ele até amansá-lo e vai de novo para a boiada. É tudo muito rápido, dura no máximo meia hora (SOARES, 1969, p. 65).

O termo 'depressa', empregado no início da passagem, e a expressão 'é tudo muito rápido', colocada ao final, corroboram a forma como a narrativa é construída. A não utilização de sujeito e o emprego de vírgulas para marcar a passagem de tempo e o encadeamento das ações, traduzem para o texto a principal característica daquele momento: não há espaço para o homem descansar e nem para que ele deguste a comida. $\mathrm{O}$ trecho tem de ser vencido, a boiada tem de avançar. Pouco importa, em realidade, como os homens vivenciam aquela experiência.

O clima do pantanal muda constantemente. No primeiro dia, a chuva torrencial da manhã dá lugar ao sol forte e quente durante a tarde. A parada para o almoço é um marco para a mudança de clima. Ao começar a desmontar o pequeno acampamento construído para a refeição, Bié demonstra, mais uma vez, suas características que visam além do perfil físico:

Bié tornou a arrumar a bagagem nas mulas. Uma delas, indócil desde a manhã, saiu correndo de repente pelo campo, acabou virando a traia e derramou toda a bagagem no chão. Bié foi até lá, arrumou-a novamente, com a mesma calma. Clarício deu-lhe um conselho:

- O senhor precisa arranjar outra mula. Essa aí vai lhe dar trabalho.

- Nada, já estou acostumado (SOARES, 1969, p. 65).

O homem, portanto, habitua-se às dificuldades encontradas com os animais. O sujeito conforma-se a entender que o animal estará certo, sendo o homem, este sim, obrigado a adequar-se ao temperamento dos bichos. Clarício, mais novo, cogita a troca da mula. Bié, mais velho, alega já estar acostumado. A personagem, considerando-se a relação que estabelece com a boiada e a fazenda, não busca mudar suas condições de trabalho. As circunstâncias fazem com que ele dispenda mais esforço nas ações, mas ele não reclama, não exige condições melhores de trabalho. Como dito anteriormente, as leis trabalhistas não 
chegaram ao Pantanal. O texto nos desvenda como as personagens são exploradas pelos donos das fazendas, os detentores do poder.

Em determinadas passagens do texto, verificamos que a escolha de palavras efetuada pelo narrador converge para uma comparação entre os homens e os animais. Ao tratar do acesso à água constatamos que ambos as personagens dependem do ambiente, buscam nele formas de saciar as carências físicas. A seguir, transcrevemos a passagem da qual tratamos:

Sob a soleira, os peões soavam litros. Mas a água é que não faltava. Nem para os bois nem para eles. Os peões nem puseram as mãos em concha para beber a água morna das lagoas deixadas pela chuva: deitaram-se à beira das poças, mergulharam o rosto, na ânsia de matar a sede. Alguns usaram um lenço na boca para coar a água barrenta (SOARES, 1969, p. 66).

Os homens deitam-se ao chão, transmutam-se em animais, deixam escapar o aspecto animalesco que neles habita. Os bois e os peões realizam o mesmo movimento, frente à sede. No entanto, apenas no último período do trecho temos a oportunidade de construir uma imagem mental mais completa acerca do ambiente: a água está barrenta, não recomendável para o consumo. Mesmo assim, apenas alguns dos peões utilizam o recurso ao lenço. Homem e animal tomam as mesmas atitudes.

Os homens não nutrem relações de sociabilidade. De acordo com o terceiro título de página (Figura 7), eles "Vivem juntos muitos dias, mas pouco se conhecem". Cada uma das personagens segue o papel que lhe foi dado pelo capataz da boiada, obedece maquinalmente aos desejos do dono da fazenda. $\mathrm{O}$ ato de se manterem distantes contribui para a construção de um sujeito que é calado, que não reage às adversidades do labor: se não dialogam, não criam laços, continuam sendo personagens isolados em meio ao Pantanal.

Mesmo os poucos movimentos que direcionam a narrativa para um momento de paz, uma suposta harmonia entre as personagens, é quebrado pelas comparações estabelecidas entre o que seria aquela ação em outros ambientes e no que ali se transforma: "Os bois vão caminhando e pastando, há tempo de os peões pararem um pouco para conversar. Nessa hora, a comitiva parece fazer um piquenique em constante movimento" (SOARES, 1969, p. 66). Um momento de compartilhamento de experiências, o piquenique daqueles homens tem de ser realizado sobre os burros, caminhando, enquanto estão atentos aos bois. 
Figura 7 - Devagar com o boi, Revista Realidade, no 37, abr. 1969, p. 66-67

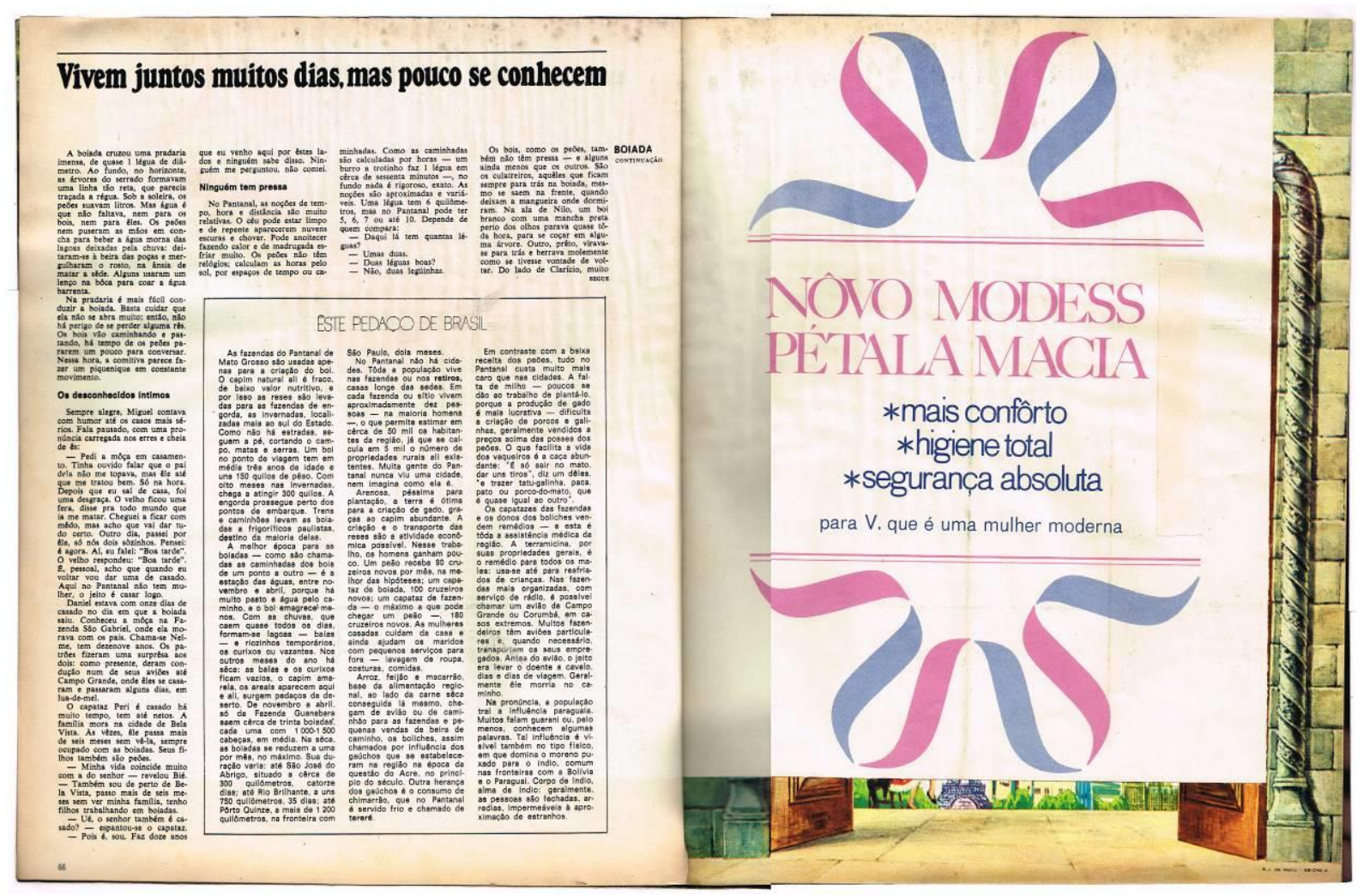

Fonte: Acervo do Grupo de Pesquisa Estudos Fotográficos (CNPq/UFCA)

Nos espaços no qual é permitida a conversa, algumas das personagens se sentem instigados a falar. Este é o caso de Miguel. O rapaz descreve para os companheiros como se deu a sua aproximação para com a futura mulher, tratando especialmente da relação estabelecida junto ao futuro sogro. Nesta passagem podemos ver um reflexo da insegurança que existe nas relações afetivas. Existe uma mudança de atitude do homem: se estiver tratando com o peão, temos uma reação; no ciclo familiar, outra:

- Pedi a moça em casamento. Tinha ouvido falar que o pai dela não me topava, mas ele até que me tratou bem. Só na hora. Depois que eu sai de casa, foi uma desgraça. O velho ficou uma fera, disse pra todo mundo que ia me matar. Cheguei a ficar com medo, mas acho que vai dar tudo certo. Outro dia, passei por ele, só nós dois sozinhos. Pensei: é agora. Aí, eu falei: "Boa tarde". O velho respondeu: "Boa tarde". É, pessoal, acho que quando eu voltar vou dar uma de casado. Aqui no Pantanal não tem mulher, o jeito é casar logo (SOARES, 1969, p. 66).

Mesmo sabendo da insegurança da situação, o homem busca a mulher. A esposa, conforme destacamos anteriormente, é entendida como uma forma de amenizar despesas. Há 
um duplo interesse do homem em arranjar uma jovem. Existe uma significativa mudança na cotidianidade do peão a partir do momento em que encontra uma possibilidade de casamento. Observando-se a forma como a figura da mulher é tratada, ela é um sujeito objetivado, atribuída de um valor específico.

Daniel, Peri e Bié são casados. Daniel casou poucos dias antes de sair com aquela boiada. Os outros dois, no entanto, vivem uma forma específica de relação familiar, característica do ambiente do Pantanal: passam cerca de seis meses distantes dos familiares, os quais residem em outras cidades, distantes das fazendas. Um diálogo entre Bié e Peri resume a situação:

- Minha vida coincide muito com a do senhor [...] Também sou de perto de Bela Vista, passo mais de seis meses sem ver minha família, tenho filhos trabalhando em boiadas.

- Ué, o senhor também é casado? - espantou-se o capataz.

- Pois é, sou. Faz doze anos que eu venho aqui por estes lados e ninguém sabe disso. Ninguém me perguntou, não contei (SOARES, 1969, p. 66).

Os homens são o que é classificado, por meio do intertítulo, como 'desconhecidos íntimos'. No entanto, não nutrem o que se possa chamar de intimidade, são apenas desconhecidos. A intimidade advinda do trabalho é uma intimidade de plástico, sem uma estrutura firme. Conhecem-se apenas no exterior, sem informações acerca do passado, do presente ou mesmo das intenções de futuro.

O tempo e o espaço merecem um intertítulo específico dentro da narrativa. Tal relevo é dado a estas duas instâncias de medida da vida por conta da relatividade que os dois conceitos possuem para aqueles homens. Sobre o tempo, o narrador traz a seguinte informação: "Os peões não têm relógios; calculam as horas pelo sol, por espaços de tempo ou caminhadas" (SOARES, 1969, p. 66). Não há rigor para qualquer tipo de medida realizada pelos peões. O mesmo acontece com os deslocamentos. $\mathrm{O}$ respaldo à informação é dado pela reprodução de um diálogo, sem personagens efetivas. A narrativa trata, neste ponto, do peão como uma categoria geral de personagem:

Uma légua tem 6 quilômetros, mas no Pantanal pode ter 5, 6, 7, ou até 10.

Dependendo de quem compara:

- Daqui lá tem quantas léguas?

- Umas duas.

- Duas léguas boas?

- Não, duas leguinhas (SOARES, 1969, p. 66). 
A incerteza paira sobre estes homens. Não há como confiar no que é dito pelas demais personagens do pantanal (como é o caso do sogro que ameaça de morte o futuro membro da família); não há estabilidade quanto aos empregos (podendo ser demitidos a qualquer momento); e não há confiança acerca das medidas de tempo e espaço. As personagens passam pelo Pantanal sem fixarem-se a referências, quaisquer que sejam elas.

Os comandos dados aos bois têm de ter um tom autoritário. Esta referência, no texto, ao autoritarismo, pode ser lida como um reflexo da situação na qual os brasileiros viviam: como sabemos, o AI5 havia sido promulgado há poucos meses. No momento em que o narrador chama a atenção do leitor para o autoritarismo que rege aquelas relações, está dando a ele a possibilidade de fazer comparações entre as duas instâncias: o mundo vivido e o mundo narrado. No texto, observamos a seguinte passagem: "A voz tem que ser grossa, autoritária. O boi não obedece a voz sem tom de comando: olha o peão e continua a pastar. Por isso, Miguel de vez em quando grita um palavrão, faz xingamentos e piadas [...]" (SOARES, 1969, p. 68). Sob o regime ditatorial desde 1964, alguns movimentos de cunho contestatório já vinham tomando forma, mas tiveram sua maior expressividade no ano de 1968. Desta forma, podemos comparar a 'voz de comando' do peão com as medidas autoritárias do governo, que dariam respaldo à censura e à tortura.

$\mathrm{O}$ texto possui marcações temporais que localizam o leitor em meio à narrativa que se forma. Há referências à posição ordinal dos dias da jornada, por exemplo. Vejamos:

Perto da Fazenda do Divino, onde a comitiva pousou na terceira noite, o burro em que João Preto ia montado deu um pulo de repente, derrubou-o e saiu correndo. João preto puxou o 32, deu dois tiros na direção do animal, mas, mesmo com raiva, teve o bom senso de não fazer boa pontaria. Limitou-se a resmungar entre os dentes:

- Se fosse meu, danado, eu te matava (SOARES, 1969, p. 68).

Outro aspecto que se destaca no trecho acima citado é o conflito observado entre os instintos do homem e as atitudes que são entendidas enquanto a melhor opção para ele próprio e para o grupo. Quando a personagem diz que, caso aquele burro fosse seu, o mataria por ter tido uma reação que é plenamente esperada de um animal, está deixando transparecer uma reação que é, essencialmente, sua. O narrador, inclusive, opta por transcrever a reação da personagem em termos de construção frasal. A morte como resposta está sendo colocada, na narrativa, pela segunda vez. Ameaça-se de morte quando há descontentamento. Contudo, o sujeito não realiza a ação. O momento em que João Preto pega o revólver gera a expectativa, 
no leitor e nas demais personagens, da morte iminente. Mas há bom senso na reação da personagem. Ele atende às duas reações a partir da realização de uma única opção: atira para expressar sua raiva; não acerta o burro para que o patrão não tenha um animal perdido.

No dia seguinte, portanto quanto dia da jornada, os bois são contatos. Observa-se que o número não sofreu modificações, o que gera felicidade. A manutenção da quantidade de reses significa a possibilidade de prêmio para todos eles. Enquanto o número se mantém, os sonhos continuam a existir. No entanto, a felicidade é parcialmente alterada no próximo intertítulo: 'Um desastre: falta um boi'.

Mesmo não tendo tido contato com a parcela da narrativa que explicita tal acontecimento, agora o leitor mantém-se na expectativa. Além disso, o peso dado ao fato o torna um 'desastre'. Os homens podem perder até dois animais, mas depois que o primeiro está perdido, a possibilidade de alcançarem o prêmio reduz-se. O título de página (Figura 8), porém, alerta-nos para um fim ainda mais trágico: 'Sumiram três bois: a jornada acaba sem alegria'. A narrativa trabalha a informação que estaria relegada ao clímax por meio de informações soltas ao longo das últimas duas páginas.

Figura 8 - Devagar com o boi, Revista Realidade, no 37, abr. 1969, p. 68-69

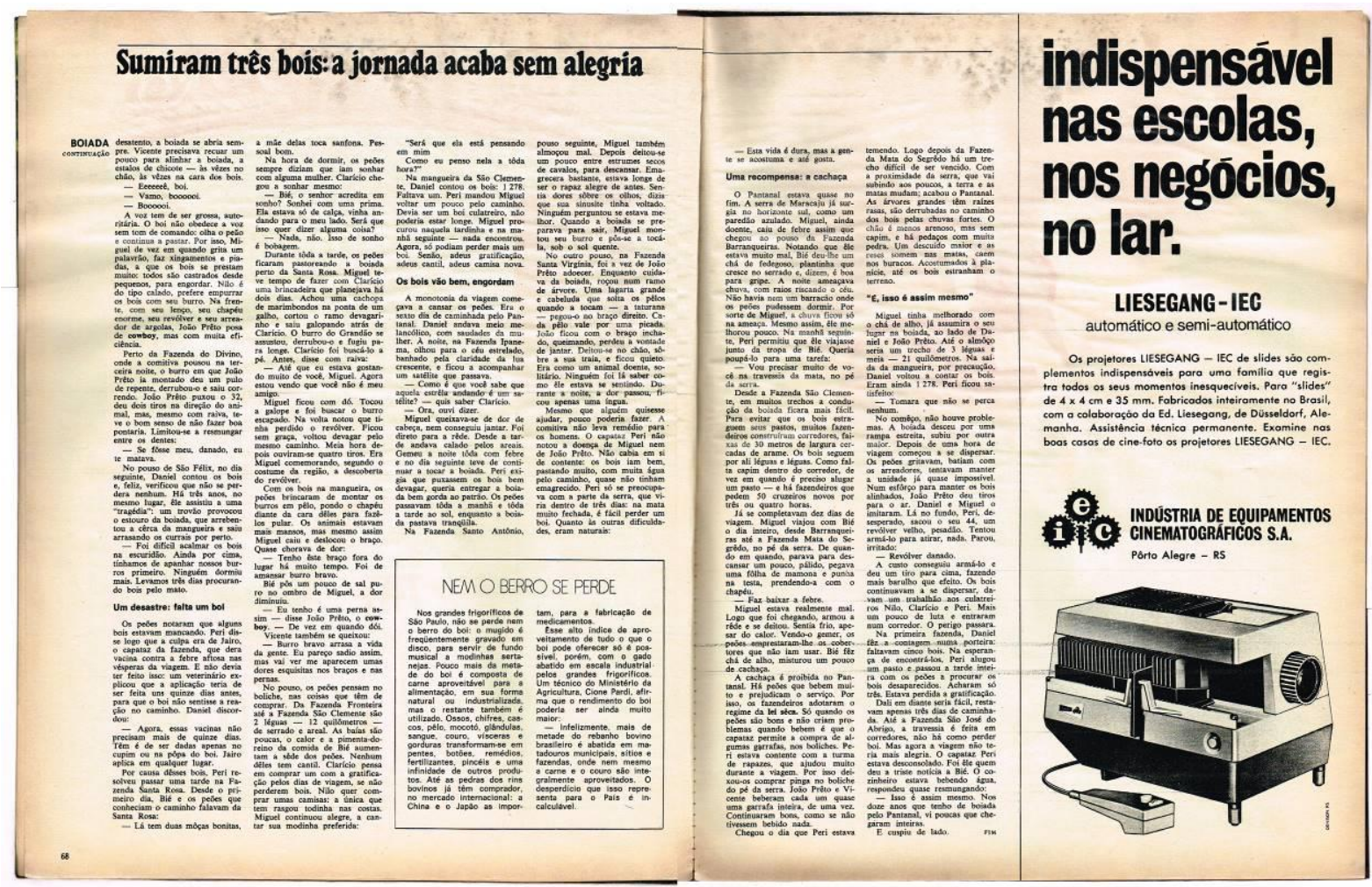

Fonte: Acervo do Grupo de Pesquisa Estudos Fotográficos (CNPq/UFCA) 
A narrativa prossegue com a descrição de um problema que acomete as reses. Alguns dos bois estão mancando, o que faz com que o capataz decida por passar a tarde descansando. Destacamos que a parada é realizada em função da saúde dos bois. A condição dos animais deve ser preservada. A parada será realizada na Fazenda Santa Rosa. Aquela jornada, o percurso realizado, conforme podemos perceber, é frequente. Os peões mais experientes já passaram por aquele local, conhecem as pessoas que ali habitam e nutrem certa expectativa quanto ao que ocorrerá. Conforme já alertado em outros extratos da narrativa, as esperanças, os sonhos dos homens, giram, entre outros focos, em torno da figura feminina:

Desde o primeiro dia, Bié e os peões que conheciam o caminho falavam da Santa Rosa:

- Lá tem duas moças bonitas, a mãe delas toca sanfona. Pessoal bom.

$\mathrm{Na}$ hora de dormir, os peões sempre diziam que iam sonhar com alguma mulher. Clarício chegou a sonhar mesmo [...] (SOARES, 1969, p. 68).

O narrador utiliza a passagem por aquela fazenda como gancho para tratar, no texto, das atitudes dos homens quanto às mulheres. Além de buscarem encontrar as moças disponíveis, os peões ainda depositam na possibilidade do sonho um momento de satisfação. Avisam que vão sonhar com as mulheres, posto que na solidão do pantanal não tenham a possibilidade de encontrá-las. Esta reação também pode ser tida como um reflexo de uma cultura que deposita na figura feminina a responsabilidade pela felicidade do homem, que transfere à sexualidade a possibilidade de satisfação pessoal, ou mesmo de fuga.

As brincadeiras realizadas pelos peões a fim de utilizarem a tarde, agora despendida em prol dos animais que não parecem estar bem de saúde, envolvem os elementos que ali estão. Miguel prega uma peça em Clarício, utilizando uma cachopa de marimbondos. Em um segundo momento, todos se divertem montando nos burros e realizando ações que os deixem mais bravos. As brincadeiras envolvem a emoção, a vontade de sentir medo, a expectativa de aumentar a produção de adrenalina na viagem, até então solitária e devagar. A segunda brincadeira culmina no deslocamento do ombro de Miguel.

A maior parte dos peões, especialmente aqueles que fazem parte dos quadros das fazendas há mais tempo, possui algum problema de saúde, advindo da lida com os animais. João Preto alega ter uma perna na mesma situação do braço de Miguel, ao passo que Vicente se queixa de uma dor que, na prática, não tem explicação: “- Burro bravo arrasa a vida da gente. Eu pareço sadio assim, mas vai ver me aparece umas dores esquisitas nos braços e nas pernas" (SOARES, 1969, p. 68). Ora, sendo os casos tão frequentes e todos sem solução, 
percebemos que os homens não têm acesso à saúde, aos hospitais. Adquirem os problemas e continuam a trabalhar, a esforçar-se. Não podem parar. Não possuem assistência do governo, não encontram facilmente os centros de saúde. Aprendem a lidar com os problemas.

\subsection{Entre a saúde e a doença: a busca pelo prêmio}

Os planos idealizados pelas personagens, descritos pelo narrador, envolvem a gratificação que almejam receber:

As baías são poucas, o calor e a pimenta-do-reino da comida de Bié aumentam a sede dos peões. Nenhum deles tem cantil. Clarício pensa em comprar um com a gratificação pelos dias de viagem, se não perderem bois. Nilo quer comprar umas camisas: a única que tem rasgou todinha nas costas. Miguel continua alegre, a cantar sua modinha preferida:

"Será que ela está pensando em mim Como eu penso nela a toda hora?" (SOARES, 1969, p. 68).

Apesar da rudeza do labor, os homens têm atitudes que descrevem outros aspectos daquelas personagens. O pouco dinheiro que recebem não possibilita que tenham uma viagem mais tranquila, com menos aspectos insalubres. Um dos sonhos materializados na narrativa por meio do narrador refere-se ao cantil. A água disponível é o mínimo que o trabalho árduo, ao sol, exigindo atenção, necessitaria. Mas os homens precisam utilizar um dinheiro extra para adquiri-lo. A prioridade, com aquilo que resta do salário, é outra: obter comida, pagar as dívidas junto ao fazendeiro. Mesmo quando optam por economizar, visam à aquisição do revólver, da arma, do signo que aponta para o poder e a autoproteção.

A passagem transcrita anteriormente é encerrada com a felicidade, romântica, de Miguel. A viagem corre bem, ainda não houve problema envolvendo o número de reses. Contudo, a calma e felicidade de Miguel é contestada pela informação que vem transcrita no parágrafo seguinte:

Na mangueira da São Clemente, Daniel contou os bois: 1278. Faltava um. Peri mandou Miguel voltar um pouco pelo caminho. Devia ser um boi culatreiro, não poderia estar longe. Miguel procurou naquela tardinha e na manha seguinte - nada encontrou. Agora, só podiam perder mais um boi. Senão, adeus gratificação, adeus cantil, adeus camisa nova (SOARES, 1969, p. 68). 
A significação da perda do boi está relacionada àquilo que os homens querem enquanto derivação da atividade. O narrador constrói o valor simbólico da não mais existência daquele animal em função do significado que tal ação possui para os peões: os objetos pretendidos estão um pouco mais distantes. Foi-se metade da possibilidade que tinham de obter êxito. O número, 1278, é o elemento utilizado para demonstrar ao leitor que houve um desfalque no agrupamento de animais. Ao repetir em diversas passagens que tudo estava bem em função do número de bois, no momento em que o leitor se depara com o novo valor, percebe que uma tragédia pode estar se anunciando. O narrador vai deixando no texto pequenos excertos que criam expectativa no leitor.

A narrativa chega ao sexto dia. Agora que os bois descansaram durante uma parcela do dia, é a vez de um dos peões adoecer:

Miguel queixava-se de dor de cabeça, nem conseguiu jantar. Foi direto para a rede. Desde a tarde andava calado pelos areais. Gemeu a noite toda com febre e no dia seguinte teve de continuar a tocar a boiada. Peri exigia que puxassem os bois bem devagar, queria entregar a boiada bem gorda ao patrão. Os peões passavam toda a manhã e toda a tarde ao sol, enquanto a boiada pastava tranquila (SOARES, 1969, p. 68).

Nesta passagem está nítida a relação feita, pelo narrador, entre o tratamento dado aos animais e aquele que é relegado aos homens. Enquanto a boiada merece o descanso, os homens são forçados a trabalhar, mesmo doentes. Enquanto os homens comem apenas duas vezes ao dia, os animais caminham devagar, pastando para não emagrecerem. Enquanto a imagem que se cria em torno dos homens leva ao trabalho exaustivo ao sol, a boiada segue tranquila, pastando e caminhando lentamente. Assim, o narrador cria dois climas para o mesmo ambiente: de um lado, os homens cansados, na outra margem, a boiada tranquila.

Na Fazenda Santo Antônio, pouso seguinte, Miguel também almoçou mal. Depois deitou-se um pouco entre estrumes secos de cavalos, para descansar. Emagrecera bastante, estava longe de ser o rapaz alegre de antes. Sentia dores sobre os olhos, dizia que sua sinusite tinha voltado. Ninguém perguntou se estava melhor. Quando a boiada se preparava para sair, Miguel montou seu burro e pôs-se a tocá-la, sob o sol quente (SOARES, 1969, p. 68, grifo nosso).

Os elementos escolhidos pelo narrador para construir a cena anterior remetem à precariedade com a qual o homem é tratado. Estando doente, tendo febre, a única opção que tem para descansar é entre os excrementos dos animais. A narrativa conduz para a construção 
de uma personagem que se submete a tudo, que se utiliza daquilo que resta dos animais para ter uma vida mais confortável. Os animais estão acima dos homens em uma espécie de hierarquia da atenção. Podemos atrelar esta informação ao fato de os demais peões não demonstrarem interesse pela saúde do colega. Voltamos ao ponto anterior: enquanto os animais merecem cuidados, os homens são levados a trabalhar.

No próximo momento de parada da comitiva, mais um dos peões demonstra estar doente: desta vez observamos o caso de João Preto, machucado por uma lagarta. Vejamos como se dá a descrição do momento de pouso do peão: "Deitou-se no chão, sobre a sua traia, e ficou quieto. Era como um animal doente, solitário. Ninguém foi lá saber como ele estava se sentindo. Durante a noite, a dor passou [...]" (SOARES, 1969, p. 68, grifo nosso). O narrador avança nas comparações que faz entre o homem e os animais. O texto explicita a condição do homem, de forma que um peão doente, ali no pantanal, assemelha-se com um animal na mesma condição. Mais uma vez, os demais integrantes não expressão sentimentos em relação à situação do companheiro. Ele sofre e cura-se sozinho.

O capataz da boiada, responsável por homens e animais da comitiva, não nutre interesse pelos peões: "Mesmo que alguém quisesse ajudar, pouco poderia fazer. A comitiva não leva remédio para os homens. O capataz Peri não notou a doença de Miguel nem de João Preto" (SOARES, 1969, p. 68). Numa segunda instância, o narrador dá como certa a impossibilidade de ajuda aos homens. Quando ainda nas dependências da fazenda, não há a opção pela ajuda aos peões. O foco está voltado aos animais, ao passo que os homens devem sofrer, caso adoeçam. Somente ao atingirem um nível extremo, ou ao ameaçarem o bom funcionamento do translado dos animais, que as personagens passam a ser notadas enquanto sujeitos:

\footnotetext{
Notando que ele [Miguel] estava muito mal, Bié deu-lhe um chá de fedegoso, plantinha que cresce no serrado e, dizem, é boa para gripe. A noite ameaçava chuva, com raios riscando o céu. Não havia nem um barracão onde os peões pudessem dormir. Por sorte de Miguel, a chuva ficou só na ameaça. Mesmo assim, ele melhorou pouco. Na manhã seguinte, Peri permitiu que ele viajasse junto da tropa de Bié (SOARES, 1969, p. 69).
}

Passando a acompanhar a tropa do cozinheiro, Miguel estará menos exposto ao sofrimento da jornada. A personagem chegará duas horas antes ao local de pouso e poderá descansar, além de não ter a obrigação de relegar atenção aos animais. O homem, no entanto, é tratado como um sujeito dotado de valor físico, tão somente. O capataz está interessado na 
utilidade do homem. No plano da expressão, a utilização do verbo 'notar' indica que o narrador tem acesso às informações proferidas ou não pelas personagens.

A narrativa chega ao décimo dia. Miguel continua doente. Contudo, os peões se sensibilizam com o adoecimento do outro: "Miguel estava realmente mal. Logo que foi chegando, armou a rede e se deitou. Sentia frio, apesar do calor. Vendo-o gemer, os peões emprestaram-lhe os cobertores que não iam usar, Bié fez chá de alho, misturou um pouco de cachaça" (SOARES, 1969, p. 69). É necessário que o sujeito explicite, por meio de ruídos, a dor que sente, para que os demais o percebam.

A cachaça não é permitida no Pantanal. Os fazendeiros esperam o melhor serviço realizado pelos peões, o que os impediria de beber. O capataz, vendo a boa atuação dos homens pode permitir a compra do líquido. Mas a lei que ali impera impede o livre consumo. Os peões devem estar inteiramente à disposição para o trabalho. No caso do comboio em questão, foi permitido que eles comprassem cachaça. Após a passagem pelos locais de compra, atingimos o ponto no qual se enfrenta a pior parcela da jornada, momento no qual chegaremos ao clímax da estória:

Chegou o dia que Peri estava temendo. Logo depois da Fazenda Mata do Segredo há um trecho difícil de ser vencido. Com a proximidade da serra, que vai subindo aos poucos, a terra e as matas mudam; acabou o Pantanal. As árvores grandes têm raízes rasas, são derrubadas no caminho dos bois pelas chuvas fortes. O chão é menos arenoso, mas sem capim, e há pedaços com muita pedra. Um descuido maior e as reses somem nas matas, caem nos buracos. Acostumados à planície, até os bois estranham o terreno (SOARES, 1969, p. 69).

Há toda a descrição do ambiente no qual se dará a parte mais intranquila da jornada. $\mathrm{O}$ narrador alega a total mudança no ambiente, no cenário. Homens e animais terão problemas: esta será a cena responsável pela maior tensão de toda a narrativa. Antes de darem início aos 21 quilômetros que fariam antes do almoço, Daniel conta a quantidade de animais. Continuam a ser 1278. O capataz tem esperanças de que não perderão nenhum. A primeira hora da jornada transcorre bem, até que os homens perdem o controle sobre os animais.

$\mathrm{Na}$ tentativa de retomarem o poder sobre as reses, os homens sacam as armas que levam: "Num esforço para manter os bois alinhados, João Preto deu tiros para o ar. Daniel e Miguel o imitaram. Lá no fundo, Peri, desesperado, sacou o seu 44, um revólver velho, pesadão. Tentou armá-lo para atirar, nada. Parou, irritado: - Revólver danado" (SOARES, 1969, p. 69). O revólver é o objeto utilizado a fim de induzir a ordem. No entanto, o mesmo 
também pode falhar. Identificamos, nesta passagem, uma leitura que recai sobre a falibilidade do autoritarismo: mesmo sendo os detentores das armas, dos símbolos do poder, os homens não conseguem controlar as reses, posto que estas sejam muitas, e, sobretudo, não atendam às leis impostas pelos homens. São livres para seguirem, para optarem por um caminho.

Após o momento de tumulto, voltam a realizar a contagem dos animais: "Na primeira fazenda, Daniel fez a contagem numa porteira: faltavam cinco bois. $\mathrm{Na}$ esperança de encontrá-los, Peri alugou um pasto e passou a tarde inteira com os peões a procurar os bois desaparecidos. Acharam só três. Estava perdida a gratificação" (SOARES, 1969, p. 69). O desaparecimento dos animais está diretamente ligado à impossibilidade da gratificação. A viagem não possuía mais o mesmo valor de antes. Os homens, antes felizes, agora estão cabisbaixos.

No entanto, cabe a Bié trazer à narrativa um dos aspectos mais relevantes: aquela não é uma tarefa fácil. Os fazendeiros prometem a recompensa em função da dificuldade de ser atingida. Conforme descrito pelo peão: “- Isso é assim mesmo. Nos doze anos que tenho de boiada pelo Pantanal, vi poucas que chegaram inteiras" (SOARES, 1969, p. 69). Os homens vivem aqueles dias de jornada esperando por um prêmio que dificilmente virá. Sofrem, prezam pelos bens do patrão, mas não recebem a recompensa almejada. Retornam à impossibilidade do cantil, à impossibilidade da camisa nova. 


\section{NARRATIVA II: O CANAVIAL ESMAGA O HOMEM}

Primeiro, o canavial derrotou a mata, expulsando-a das terras férteis para o alto das montanhas. Depois, tomou conta dos varjões, ocupou várzeas e baixadas, cercou cidades, obrigou os pássaros a emigrar. E é nesse mar verde, de folhas afiadas como navalhas, que se passa a história de milhares de brasileiros, os trabalhadores dos engenhos. A história de Gregório, humilde, analfabeto, envelhecido, que levanta às 3 da madrugada e, armado de foice, vai buscar o sustento da mulher e de seis filhos. (ANDRADE, 1970, p. 32)

A reportagem $O$ canavial esmaga o homem foi publicada na edição 46 de Realidade, no mês de janeiro de 1970. Os repórteres, Jorge Andrade e Jean Solari, viajaram para o estado do Pernambuco em busca dos engenhos de rapadura, dos canaviais e, em especial, daquelas personagens que são responsáveis por manterem o canavial pulsando, em atividade: o trabalhador do engenho.

$\mathrm{Na}$ abertura de tal reportagem, o canavial é apresentado ao leitor como uma personagem viva, que tem a capacidade de exigir espaços, derrotando a mata, tomando o lugar que era, por direito, dela. O canavial vai, por meio do fragmento anterior da narrativa, tomando os espaços naturais, crescendo, muito rapidamente, e modificando a paisagem. Além disso, a cana também é dotada de armas naturais, que maltratam os trabalhadores de engenho: as folhas são como navalhas, cortam, machucam, afastam, mas lá estão, todo o tempo.

$\mathrm{O}$ mar verde que se forma nos canaviais aprisiona homens, mulheres, crianças e idosos. Quem olha a partir de um prisma externo, enxerga apenas as folhas que se mexem com o vento. Quem está ali dentro, observa a vida passar, vê a sua história ligada ao canavial. Mais que isso, sente-se como um sujeito fadado a travar uma luta diária contra o canavial. Podemos observar isso quando o narrador apresenta a personagem principal desta narrativa, Gregório. Este homem é humilde, analfabeto, envelhecido e, cotidianamente, levanta-se às três horas da madrugada, pega suas armas e vai ao canavial. 
Na luta, o homem almeja alcançar uma vida mais digna e confortável para a mulher e os filhos. Buscar o sustento, o alimento que os vai manter vivos. Ao mesmo tempo em que está ali preso, vendo sua história, e de muitos outros, passar, Gregório consegue no canavial a remuneração que permitirá o acesso ao alimento. Aqui começa a ser traçada uma relação de alternância em torno dos significados dados ao canavial: ao mesmo tempo em que é vilão, maltratando o homem, também é mocinho, tornando possível a sobrevivência. Ao longo desta discussão, veremos mais exemplos dessa alternância de significados.

A abertura da reportagem, conforme podemos observar na Figura 9, dá-se por meio de uma imagem que ocupa cerca de três quartos da página dupla e uma massa de texto localizada no lado esquerdo da página. O recorte realizado na fotografia de Solari, em formato circular, possibilita que vejamos um homem e um aglomerado de canas cortadas, como motivos principais da imagem. Podemos observar que o homem está extremamente magro, usa um chapéu como forma de proteção contra o sol e está sentado no chão, no mesmo nível que os pedaços de cana.

Figura 9 - O canavial esmaga o homem, Revista Realidade, n 46, jan. 1970, p. 32-33

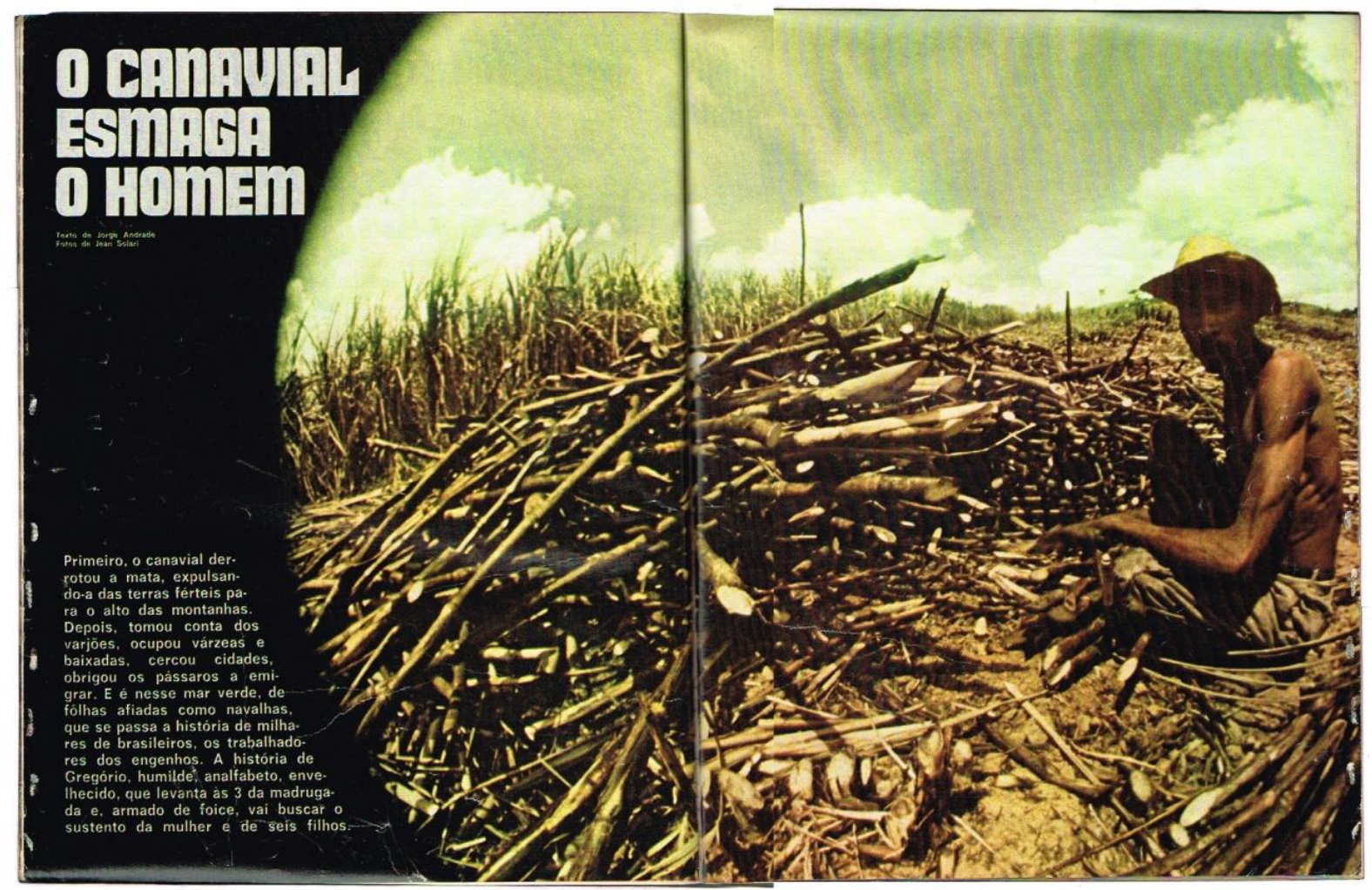

Fonte: Acervo do Grupo de Pesquisa Estudos Fotográficos (CNPq/UFCA) 
A partir deste enquadramento, podemos traçar um paralelo entre os dois sujeitos: canavial e homem se encontram em um mesmo nível, ambos sofreram com uma luta que é diária. A cana foi retirada do canavial, estando colocada aos montes no chão, ao passo que o homem está magro, sujo e com uma expressão de tristeza nos olhos. No segundo plano, o canavial continua lá, de pé, verde, exigindo mais trabalho do homem.

Assim, o título e a fotografia travam um diálogo no qual o canavial continua em sua forma original após a batalha, prevalecendo sobre a imagem do homem, esmagado pela imensidão do espaço, por sua resistência e por suas armas naturais. O texto de abertura contribui para esta leitura que remete a uma luta, uma vez que o canavial vai derrotando todos os elementos naturais do ambiente, cria um novo cenário no interior do Pernambuco e ali dispõe os combatentes e suas armas: as folhas da cana são afiadas como navalhas, ao passo que o homem arma-se com uma foice, também afiada.

Uma das características do canavial enquanto personagem é a autoridade. Os verbos utilizados ao narrar a tomada realizada sobre aquele espaço são: derrotar, expulsar, tomar, ocupar, cercar e obrigar. O canavial dita regras sobre o espaço e sobre os animais. Todos os elementos remetem ao autoritarismo, à força. Ao tomar para si as características que seriam esperadas do dono do engenho, o canavial torna-se o vilão.

Ao dar início ao texto da reportagem, o narrador aponta os riscos que aquela atividade, ou batalha, implicam. Há perigo no canavial. Além da própria cana, que solta alguns pelos que entram na pele como espinhos, também existem perigos naturais, como é o caso das cobras que ficam escondidas na base das touceiras de cana e saem quando o homem começar a cortar a planta. O primeiro elemento está mais visível e próximo do sujeito que o segundo. Tomamos os espinhos como a representação do conhecido, ao passo que a cobra representa o desconhecido, uma vez que o homem sabe de sua existência, mas não tem como prever onde ela está ou quando o atacará.

\subsection{A luta entre o canavial e o homem: duas personagens contraditórias}

O texto tem início com uma descrição da luta travada entre o canavial e a mata. Aqui, percebemos a continuação de uma escolha tomada pelo narrador deste o texto de abertura: descrever o canavial enquanto sujeito ativo das ações. Vejamos mais detidamente o trecho que dá início ao texto: 
A luta entre o canavial e o meio foi assim: no princípio, a mata, generosa, cedeu pequenas clareiras para que a cana pudesse brotar e crescer. Crescendo, pediu pedaço maior de terra. A mata cedeu. Sabendo que continha grande riqueza e que os homens lutariam, sofreriam e morreriam por ela, a cana não mais pediu: exigiu (ANDRADE, 1970, p. 34).

A luta avança com autoritarismo e indiferença em relação ao primeiro habitante daquele local, a mata. Além disso, toma como base o próprio valor, econômico, para dar sequência à tomada do espaço. $\mathrm{O}$ canavial enxerga no homem a mesquinharia e a ganância, uma vez que, por ela, ele luta, sofre e morre. A mata é generosa, o canavial e os homens, enquanto conjunto de indivíduos, gananciosos.

O texto destaca que a cana foi plantada pelo homem, espalhou-se e expulsou a mata do convívio daqueles. A descrição do final desta batalha entre o canavial e o homem constrói a figura da mata enquanto sujeito exilado daquele ambiente: "A mata resistia nas encostas, o canavial lançava seus braços em volta. Se a mata se defendia de uma lado, o canavial atacava de outro. Até que a mata foi se acocorar no alto dos morros, somente onde o homem não conseguia se manter de pé para trabalhar" (ANDRADE, 1970, p. 34).

As passagens que se referem à construção do ambiente da narrativa vão desde elementos físicos até os sons que inundam o local. Após relatar que a cana expulsou todos os animais, ocupou espaços que antes eram tomados por outra vegetação e cercou os ambientes de convívio do homem, uma frase descreve o atual cenário da região: ali "Há uma mar verde que, quando ondula batido pelo vento, produz um som seco e áspero" (ANDRADE, 1970, p. 34, grifo nosso). Até o som do ambiente machuca, atormenta.

O elemento descritivo 'mar verde', no parágrafo seguinte, tem seu sentido bruscamente alterado: passa a ser "[...] uma prisão verde, onde milhares de homens, mulheres e crianças já terminaram seus dias e outros estão terminando" (ANDRADE, 1970, p. 34, grifo nosso). O termo mar produz uma imagem de espaço que abriga elementos desconhecidos, porém, transmite uma sensação de beleza, de calma. Ao transmutar a palavra mar em prisão, temos como referência um local fechado, onde conhecemos aqueles que ali estão presos, porém, o indivíduo externo ao ambiente não sofre como aquele que está recluso, não percebe as reais dificuldades da relação estabelecida com as grades, com o confinamento.

Avançando no significado de tais grades, o narrador descreve a natureza do elemento: "Paredões canavieiros, grades açucaradas construídas pelo próprio homem para se aprisionar" (ANDRADE, 1970, p. 34). A imagem do canavial começa a ganhar traços mais claros. Ali observamos paredões, objetos intransponíveis, quer fisicamente, quer socialmente. As grades, 
por sua vez, são açucaradas: são, assim, grudentas, pegajosas. Mas o responsável por todo o sofrimento é o próprio homem. O homem é o prisioneiro e o aprisionador. São sujeitos escravos do próprio canavial. As funções de cada uma das personagens são alternadas constantemente, como veremos no decorrer desta análise.

Todo o embate acontece em um engenho denominado Flor da Ilha. Ali, as canas possuem cerca de três metros de altura, há cinquenta canas por metro quadrado e três mil alqueires de extensão. O mar/prisão verde, assim, é formado por mais de três bilhões de canas. "Umas de pé, outras caídas, muitas cruzadas, uma infinidade delas entrelaçadas, cercando por todo lado" (ANDRADE, 1970, p. 34): o narrador traça uma descrição detalhada do ambiente, construindo uma imagem de desorganização e mesmo de perigo, especialmente ao ser relacionado com a existência de cobras naquele espaço.

Por fim, antes de passar ao próximo intertítulo, o texto de apresentação do ambiente e do conflito a ser travado apresenta uma definição acerca do canavial: "[...] riqueza e alimento do homem -, lugar onde o açúcar é amargo" (ANDRADE, 1970, p. 34). De onde vem o sabor atribuído à cana? No decorrer do texto o narrador dará mais indícios sobre a utilização de tal adjetivo, mas já temos elementos que podem começar a explicar a adjetivação. Ao mesmo tempo em que alimenta, a cana também traça correntes em torno da personagem, prendendo-o ao ambiente, ao engenho, à região. Os perigos são tantos e tamanhos que a vida se torna uma sequência de preocupações, todas relacionadas ao sustento. O canavial prende, sufoca, machuca. Não pode haver, num ambiente assim descrito, espaço para a doçura: nem mesmo no açúcar, produto final da produção.

Após a apresentação do espaço físico daquela região, tomada pelo canavial, a narrativa nos apresenta Gregório, personagem já parcialmente descrito no texto de abertura. Gregório gosta de sonhar, e o faz acordado: as cinzas do canavial penetram na pele e não deixam os trabalhadores dormirem. Eles levam o canavial consigo, entrando em casa e fazendo parte da vida do trabalhador das mais variadas formas.

A apresentação da personagem de Gregório começa durante a madrugada, com ele ainda deitado. $\mathrm{O}$ autor mescla as informações referentes ao canavial com dados que traçam as características físicas e sociais daquele espaço. Vejamos um exemplo: "Na noite que custava a passar, Gregório olhou à sua volta, medindo as paredes do quarto: 3 metros por 2" (ANDRADE, 1970, p. 34). De maneira sutil, o narrador aponta as proporções do aposento. Neste quarto dormem Gregório, sua mulher Dalvanise, Matilde e Madalena, filhas pequenas. 
$\mathrm{Na}$ sala ainda dormem Severino e Joaquim, também filhos. Gregório teve sete filhos, dos quais cinco ainda moram com ele.

O trabalho ali realizado engloba todas as instâncias da família. Dalvanise levanta cedo e vai preparar a comida que Gregório levará para comer em meio às canas, às três horas da tarde. Ela também é a responsável por chamá-lo quando está na hora de ir se aprontar para o dia de trabalho. Quanto às crianças, o mais velho daqueles já foi convocado a trabalhar como adulto no canavial:

Severino, de oito anos, não ia ao corte de cana naquele dia: estava com o peito cheio. Cabrinha macho, esse! Com a ajuda dele, tinha cortado tonelada e meia de cana por dia durante a semana. Gregório sentiu frio e encolheu o corpo: acho que é falta de sangue. É por isso que o corpo não se esquenta (ANDRADE, 1970, p. 34).

Em outra reportagem, de 1968, Realidade já tratou dos problemas de saúde e sociais existentes na Zona da Mata de Pernambuco. Um leitor contínuo da revista pode perceber a intertextualidade entre as duas reportagens. Intitulada Eles estão com fome, com texto de Eurico Andrade e fotografias de Jorge Butsuem, o texto apresenta a questão da fome enquanto endêmica naquela região. O quadro apresentado é dramático: as pessoas comem metade do que precisam para sobreviver; a situação é comparada à África e ao Extremo Oriente; a mortalidade infantil está presente em todas as famílias; as doenças decorrentes do déficit alimentício vão desde deformações físicas até anemia profunda e lesões nos olhos e na pele.

O narrador de Eles estão com fome descreve as perspectivas de futuro daqueles brasileiros e a percepção que eles têm em relação à região:

O futuro da vila é pouco animador. Dos 11 mil habitantes, 49 por cento têm menos de dezesseis anos, há quinhentas prostitutas, e apenas seiscentas crianças - das 2 mil em idade escolar - conseguem matrículas. Noventa e nove por cento da população sofre de uma ou mais verminoses. Das 340 mortes ocorridas no ano passado, 226 (67 por cento) foram de crianças até um ano de idade. Doze por cento dos mortos eram adultos. E a vila continua crescendo: os camponeses acham que nela a situação é melhor do que nos engenhos (ANDRADE, 1968, p. 160).

É num contexto bem parecido com aquele, apenas dois anos depois, que se encontra a parcela da população que depende do Engenho Flor da Ilha. Gregório pensa que a falta de sangue pode ser a responsável pelo frio que sente. Assim, o narrador apresenta mais um dos problemas da região, tanto referentes à saúde quanto à alimentação. Se os homens se 
alimentam mal, problemas como anemia podem, e provavelmente vão, surgir. No caso dos trabalhadores de engenho, eles se alimentam da própria cana, fonte de glicose e sacarose, o que ajuda na manutenção da vida.

O texto também reproduz alguns diálogos. Um deles envolve Gregório e Dalvanise, no momento em que ela está terminando de preparar o alimento que o marido levará para o canavial. Neste trecho, outras informações são condensadas, como é o caso da alimentação das crianças:

- A farofa tá pronta.

- Que tem mais?

- Taquinho de bacalhau.

- Só?

- Só. Semana que vem, dou uma demão. Sobra mais dinheiro.

- Vida danada!

- Pensa em Deus, Gregório.

- E no que mais vou pensar, mulher?

- Se não fosse o canavial, como é que a gente ia viver?

- O leite Ninho do Madalena acabou?

- Precisa mais não. Já tá com dois anos. Severino é que precisa de chá de capim-santo. Na encosta do morro do Tigre tem (ANDRADE, 1970, p. 34).

Assim, compreendemos que a dieta daquelas pessoas é baseada, substancialmente, na farinha de mandioca, comum no Nordeste. O peixe, mais barato em função da proximidade com o mar, também integra a dieta. Porém, podemos observar que todos os integrantes da família estão sujeitos ao mesmo tipo de alimentação. Mesmo a mais nova das filhas, Madalena, deixará o leite e passará à farinha. Apenas quando doentes as crianças merecem outro tipo de alimentação, como é o caso do chá para Severino.

Outro aspecto importante levantado pelo diálogo é a relação com Deus. Como não têm onde buscar a esperança, no plano físico, a buscam no plano espiritual. O governo não atende àquelas pessoas, o canavial (e os donos de engenho) explora aquela mão de obra, o pouco que recebem não proporciona uma alimentação adequada. Quanto à saúde, não buscam remédio junto a médicos, mas sim na própria vegetação. E, importante, conhecem a região tão bem que sabem onde encontrar as folhas necessárias para tratar cada tipo de enfermidade.

Estas pessoas veem no canavial a única forma de se manterem. A perspectiva da vida sem o canavial é muito pior, de forma que agradecem à existência do mesmo, deixando, temporariamente, de pensar sobre todo o sofrimento causado. Como a maior parte daquela população não tem acesso à educação formal e, consequentemente, a outras atividades, acostuma-se com o canavial. Aqui, o canavial alterna, mais uma vez, sua função: passa de 
vilão a única esperança de sobrevivência. Para o marido, o canavial proporciona uma vida danada, difícil. Para a mulher, a não existência do canavial tornaria as condições piores.

O texto apresenta mais uma divisão, denominada Guriatã. Esta palavra se refere a um pássaro, conhecido por seu canto. A ave possui plumagens amarelas ou violetas. A disposição das mesmas se dá de acordo com o sexo. O Guriatã é

Um dos melhores imitadores. Um único macho pode se manifestar em poucos minutos na voz de 10 a 16 espécies de aves diferentes. São imitações perfeitas, mas traduzidas para sua própria força vocal reduzida. O repertório do gaturamo se torna a cópia fiel da avifauna da região em que vive. ${ }^{36}$

No entanto, o texto faz referência a um dos poucos pássaros existentes naquela região. O guriatã de Gregório está preso em uma gaiola. As aves da região foram expulsas pelo canavial. Aquela, caracterizada pelo poder de cantar, não tem a quem imitar. Está muda. Ao sair em direção ao canavial, Gregório pede à mulher que não se esqueça de alimentar o pássaro. A mulher reclama: não vê motivos para alimentar um pássaro que não canta, quando todos eles precisam de alimento (ANDRADE, 1970, p. 34).

As armas de Gregório para a batalha diária que se aproxima são a foice e um embornal contendo o resto da farofa feita por Dalvanise. Ao sair, lembra-se de como criou seus filhos e da relação com a fome e a comida disponível:

Tive sete filhos. Ninguém bota banca comigo. Criei meus filhos com esses braços. Ninguém nunca me ajudou. Farofa, taquinho de carne há 54 anos. É só. Asneira dizer que come. A gente enche a barriga, mas a danada da fome volta logo. Sou cabra bom. Não tenho vexame de dizer. Os dedos da mão não são iguais (ANDRADE, 1970, p. 34).

Este trecho do texto aglutina diversas informações, aparentemente desconexas. No entanto, podemos perceber o encadeamento das ideias da personagem: o homem diz que aquela vida é difícil, especialmente por conta do alimento que conseguem adquirir, no entanto, vangloria-se de ter criado os sete filhos apenas com a força do seu trabalho e todos, assim como ele, estiveram expostos à mesma dieta, farinha e alguma outra coisa para misturar. Ao vangloriar-se de sua força e coragem, deixa transparecer que ali existem outros que não são como ele, que precisam de ajuda.

\footnotetext{
${ }^{36}$ Texto "Gaturamo-verdadeiro". Disponível em: $<$ http://www.wikiaves.com.br/gaturamo-verdadeiro $>$. Acesso em: 03 abr. 2015.
} 
A comunidade na qual vivem Gregório e sua família é composta por 20 casas, todas iguais, ao menos vistas do lado de fora: "Gregório se volta e olha a casa: uma entre vinte emendadas. Muro branco, indistinto. Ilha de alvenaria cercada de cana por todos os lados" (ANDRADE, 1970, p. 34). Além de viverem em casas parecidas, estes homens também estão cercados pela cana, que toma absolutamente todos os lugares vazios da região.

Ao sair para trabalhar, Gregório imagina o trabalho na semana seguinte, quando será lua cheia. Durante estes períodos, quando a noite é bem iluminada, os homens trabalham por mais tempo, recebem mais dinheiro. É pensando em um presente para Dalvanise que ele dá início a sua caminhada de oito quilômetros até o local do corte da cana.

Após descrever o ruído realizado pelas touceiras de cana, o narrador agrega características ao aroma que toma o ar. No caminho para o canavial, Gregório sente o cheiro do melado. O narrador descreve o ambiente e ali conduz a personagem. Ao passar pelo engenho principal, fica observando quando as canas são descarregadas pelos caminhões. $\mathrm{Na}$ primeira máquina, 32 navalhas, de cerca de meio metro cada, picam 60 toneladas de cana a cada hora durante o período da safra, de seis meses (ANDRADE, 1970, p. 34-37).

Figura 10 - O canavial esmaga o homem, Revista Realidade, nº 46, jan. 1970, p. 34-35

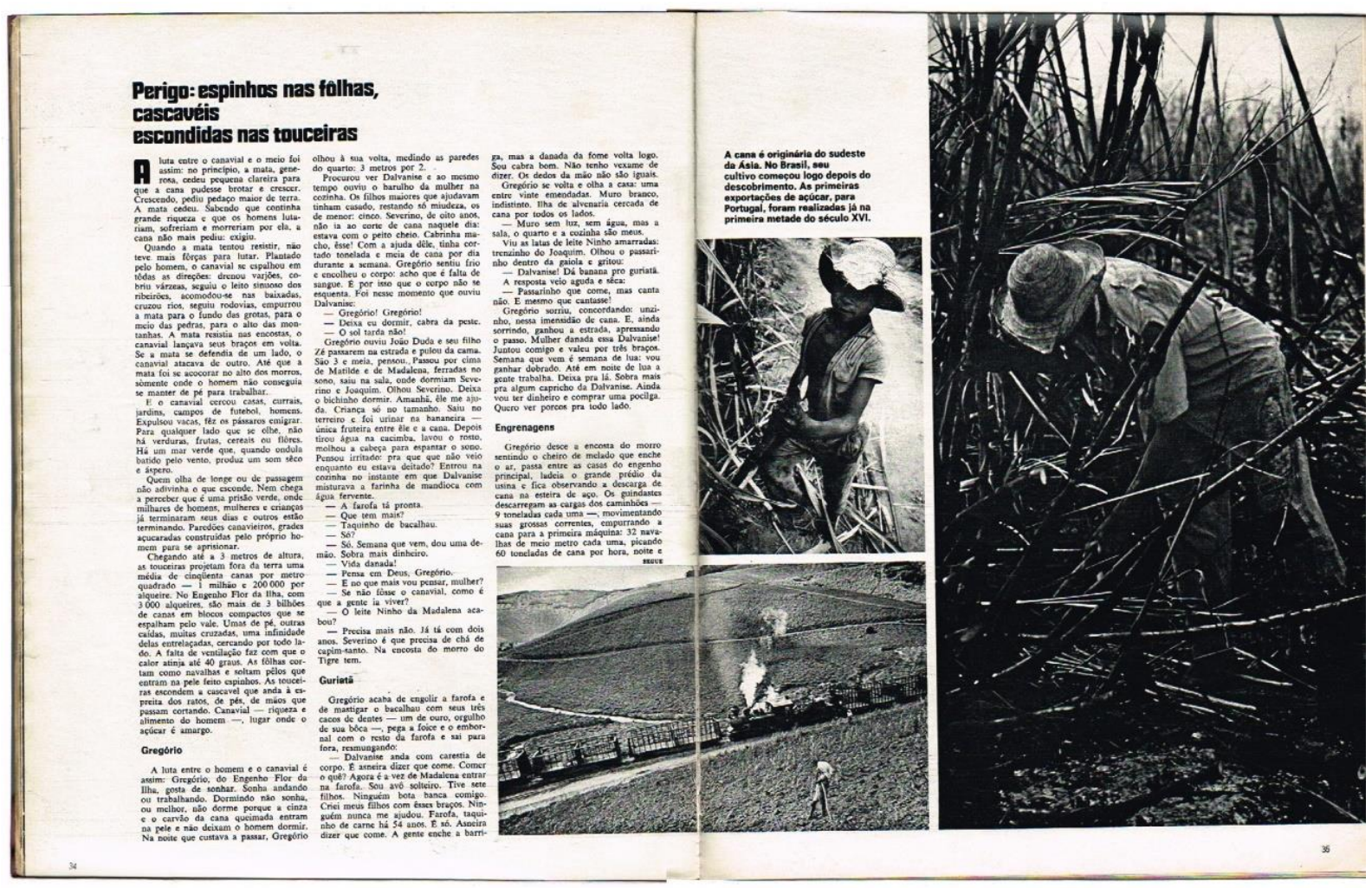

Fonte: Acervo do Grupo de Pesquisa Estudos Fotográficos (CNPq/UFCA) 
Acompanhando toda esta massa de texto apresentada, três fotografias localizam o leitor visualmente no enredo da reportagem (Figura 10). Diferentemente da imagem de abertura, colorida, as fotografias dispostas entre as páginas 34 e 35 estão em preto e branco. Na primeira delas (topo), uma criança, do sexo masculino, está entre o canavial e uma estrada. Pequeno, o menino segura uma cana cortada nas mãos. As crianças ali trabalham como adultos. Ajudam os pais e realizam o mesmo tipo de atividade. Com a pele queimada pelo sol, utilizando roupas rasgadas, o menino está sujo pela fuligem ali existente. Além disso, um chapéu o protege do sol, ao mesmo tempo em que esconde seu olhar.

Ao lado direito da imagem do menino, podemos observar um homem trabalhando. Ele está curvado, dando relevo ao movimento necessário para o corte da cana. O homem está cercado pelo canavial. Algumas das canas já estão cortadas, outras ainda em pé. Suas vestes são semelhantes às utilizadas pela criança da fotografia ao lado. $\mathrm{Na}$ imagem prevalece o tom mais escuro, em especial por conta da queimada que é realizada no canavial antes do corte.

$\mathrm{Na}$ última fotografia desta página, uma personagem, sobre a qual não é possível definir sexo ou idade, está parada, observando os vagões de trem que passam pela estrada de ferro. A sensação transmitida é de solidão do sujeito em meio a esta extensa massa de terra. Além disso, os vagões estão de passagem, em leve movimento, ao passo que ele está parado, fixado naquele espaço, sem ter como atravessar a linha férrea.

\subsection{O embate se intensifica: a busca pela vingança}

Estes campos e o canavial fazem parte do percurso realizado por Gregório até alcançar o canavial. Ainda caminhando, ele pensa sobre a influência do canavial sobre a vida de todos, até dos que ali não residem. Sobre o período de safra, ele afirma: "Tempo de trabalho pra todo mundo, quando os parentes e conhecidos do Agreste vêm com as famílias ganhar o dinheiro para sustentar os pequenos roçados" (ANDRADE, 1970, p. 37).

No entanto, ao longo do caminho, o momento de maior satisfação para Gregório se dá quando ele alcança as navalhas e enxerga as pernas dos trabalhadores, que empurram a cana para dentro das máquinas como raios daquelas engrenagens. Da mesma forma, seus braços seriam raios das foices (ANDRADE, 1970, p. 37). Todos trabalham em conjunto para transformar a cana em álcool e açúcar. O olho desta página expressa o sentimento do homem em relação à cana: "Vingança: ver a máquina despedaçar a cana". Ele usa o verbo despedaçar, pois é assim que se enxerga em relação ao canavial. Em pedaços. Destruído pelo trabalho 
árduo e contínuo, quase não rendoso. Gregório sonha em um dia trabalhar nas máquinas para, assim, observar sua vingança de perto.

Este momento de satisfação, porém, é intercambiado com o sentimento que circunda a imagem da cana. De vilã a mocinha, a cana é trazida ao texto mais uma vez como aquela que dá o sustento. Em meio a um pensamento de vingança, surge o arrependimento pelos sentimentos ruins em relação ao canavial:

- Um dia, vou trabalhar na esteira só para ver essa amaldiçoada ser esmagada até virar mais bagaço do que eu.

Espantando o pensamento - pois não é a cana que dá o sustento? -, Gregório se voltou e viu o Opala do dono da usina - máquina formosa! - e lembrou: amanhã temos pagamento. Dia de pinga (ANDRADE, 1970, p. 37).

O homem busca elementos que o equiparem à cana. Após um dia de trabalho, ambos tornam-se bagaço, restos. Sua vingança consistiria em fazer com que a cana sofresse mais que ele. O dono do engenho é aqui representado apenas pelo seu carro, demonstrando o afastamento existente entre os dois sujeitos. Assim como as máquinas do engenho, a 'máquina' do dono do engenho causa emoções positivas ao trabalhador. Ao ver o carro, Gregório lembra-se do pagamento no dia seguinte. Mais que isso, lembra que o dia de pagamento é sempre seguindo por uma visita ao bar. O dinheiro vem seguido pela busca na bebida para aliviar as tensão do dia a dia e esquecer as dificuldades da vida.

Gregório ganha nova esperança ao lembrar-se do pagamento e continua sua caminhada até o canavial. Passa por uma ponte, sobre o rio Serinhaém (mais um elemento de construção o ambiente), não utiliza calçados e relembra as funções que já teve naquele ambiente de engenho:

- Já trabalhei plantando, carpindo, embolando mato, envenenando cana, despalhando folha seca, cortando, amarrando, até como cambiteiro. Já fui arrastado por burro morro abaixo, rolando misturado com cambitos cheios de canas. Na próxima safra vou trabalhar na usina [...] Quero ver a cana gemer, virar mina de garapa como meu corpo é de suor (ANDRADE, 1970, p. 37).

De ambos, homem e cana, é extraído algo. Restam apenas partes não utilizáveis. O homem descreve a si mesmo como um bagaço. Sua força, sua coragem, seu suor, sua vida, ficam no canavial. São retirados pela cana. A vingança seria aplicar o mesmo destino a ela: retirar-lhe a força, a resistência, a forma, o suor, o caldo. 
Figura 11 - O canavial esmaga o homem, Revista Realidade, n ${ }^{\circ}$ 46, jan. 1970, p. 36-37

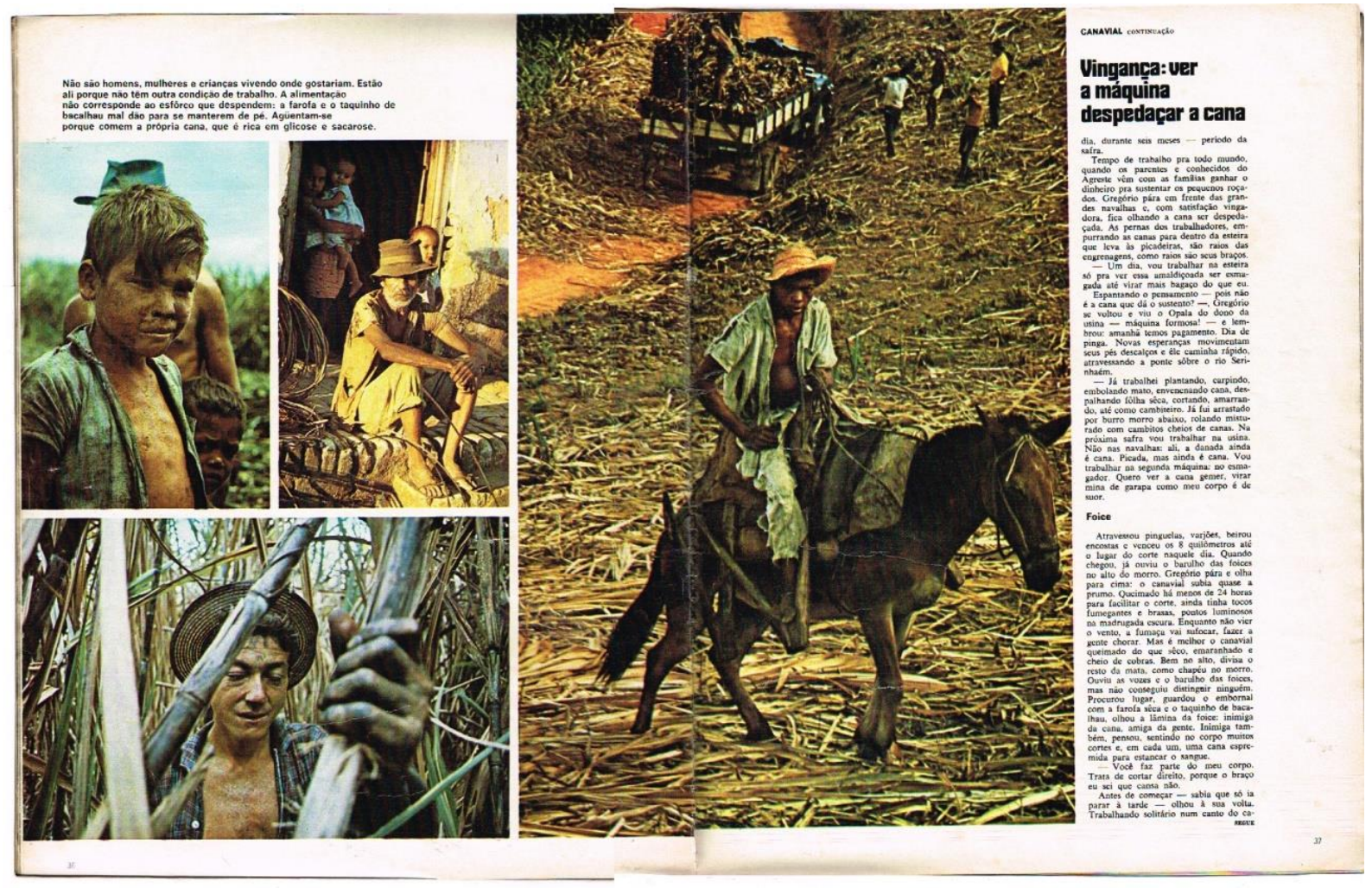

Fonte: Acervo do Grupo de Pesquisa Estudos Fotográficos (CNPq/UFCA)

A terceira página dupla desta reportagem (Figura 11) conta com quatro fotografias, ocupando cinco sextos da página e mais uma coluna de texto, à direita. A legenda das fotografias diz:

Não são homens, mulheres e crianças vivendo onde gostariam. Estão ali porque não têm outra condição de trabalho. A alimentação não corresponde ao esforço que despendem: a farofa e o taquinho de bacalhau mal dão para se manterem de pé. Aguentam-se porque comem a própria cana, que é rica em glicose e sacarose (ANDRADE, 1970, p. 37).

Ali vivem famílias inteiras, não por opção, mas por obrigação, por não terem nenhum outro lugar no qual vislumbrem uma possibilidade de sobrevivência. Aquela região vive em função da cana, dos engenhos. A alimentação proporcionada pelo dinheiro conseguido ali não é o suficiente para repor proteínas e carboidratos. Gastam mais energia do que ingerem em casa ou nas marmitas que levam para o canavial. A farinha, apesar de proporcionar energia, não se faz suficiente. A cana, ao mesmo tempo em que ataca e maltrata, também dá a sustentação necessária. 
As fotografias desta página são coloridas. O mosaico iconográfico da página é composto por quatro fotografias. Três em tamanho menor e uma em destaque. Todas têm personagens bem definidas, construindo a imagem do homem do canavial. Na primeira delas, um menino é o motivo principal. Atrás dele, outra criança, menor, e a silhueta de um homem, dando vistas aos braços, costelas e um chapéu. As duas crianças podem ser da mesma família, considerando que a menor usa a maior para se defender, esconde-se atrás do menino. Ambos estão sujos. $\mathrm{O}$ menino maior esboça um sorriso, assim como aquele que podemos perceber na criança representada na página dupla anterior. Não estão felizes, mas, ao serem fotografados, demonstram simpatia com aqueles repórteres. O menino menor, por sua vez, tem na expressão marcas de cansaço e sofrimento. As sobrancelhas, curvadas, apontam para o desconforto da situação. No homem posto no segundo plano, podemos observar sua magreza, a partir do não uso da camisa: suas costelas contrastam com os braços de músculos definidos. Em oposição à magreza dos homens, podemos observar que a criança tem a barriga acentuada, o que pode apontar para doenças provocadas por verminoses.

Na segunda fotografia da página, quatro pessoas estão postas entre a calçada de uma casa e a porta. Um desses sujeitos tem feições masculinas, sendo adulto, ao passo que as outras três são crianças, um menino e duas meninas. O homem está na calçada, com os pés apoiados em um degrau. Sua feição é séria, seus braços são queimados pelo sol e o chapéu, mais uma vez, não nos permite ver os olhos da personagem. Sujo e com as roupas apresentando rasgos, é um típico trabalhador do canavial, levado para outro cenário: a casa. A calçada, na qual está sentado, apresenta desgastes do tempo, onde o rejunto que ficaria entre os tijolos não mais existe. Além disso, a parede da casa também apresenta desgastes. Ao redor deste sujeito, as três crianças estão paradas e observam o fotógrafo. Das três, apenas a menor de todas, no colo e dentro de casa, aparece esboçando um sorriso. Na penumbra, as crianças quase não podem ser vistas. Completando o cenário, alguns fios estão dispostos sobre a calçada.

A terceira fotografia nos apresenta um homem preso em meio ao canavial. Seus olhos estão inchados, o que pode ser um reflexo das poucas horas de sono, ou mesmo dos problemas acarretados pela queima da cana. Ele direciona o olhar para a parte inferior das canas, parte não presente na fotografia, mas podemos perceber a sua atenção ao que faz: cortar a cana. Ainda como reflexo das queimadas, as mãos do homem estão pretas de fuligem. O corpo dele brilha, em função do calor naquele local: cerca de $40^{\circ}$. Parece cansado e triste, um verdadeiro prisioneiro da situação. Suas roupas deixam ver a magreza. O foco da imagem 
está no homem. O primeiro plano, composto pela mão da personagem e algumas canas, está desfocado.

Na última fotografia podemos observar um jovem montado em um cavalo. Todo o chão está coberto por palhas de cana. Este é o local no qual os caminhoneiros recolhem o produto do trabalho dos homens e o transportam ao engenho. Podemos fazer esta observação em função da presença do caminhão no segundo plano da fotografia. $\mathrm{O}$ carro tem um caminho já traçado, o qual divide o canavial em duas porções: de um lado, as sobras da cana, do outro, algumas plantas ainda de pé. Naquele local também podemos distinguir a presença de ao menos cinco pessoas: uma em cima do caminhão e outras quatro ao lado. O jovem, motivo central da fotografia, usa roupas rasgadas e um chapéu para proteção contra o sol, bem como tem um semblante de desconforto com a fotografia. Apesar da magreza, este rapaz também apresenta uma barriga acentuada, assim como outras crianças de fotografias anteriores.

Cada uma das personagens utiliza uma mesma arma contra o canavial: a foice. É justamente esse termo que dá nome ao próximo intertítulo. Observamos que a palavra 'foice' tem a mesma representação sonora de 'foi-se'. Aqueles sujeitos estão presos a uma vida na qual o caminho é sempre o mesmo: ir para o canavial durante a madrugada e voltar de lá no final da tarde. Despende-se a vida ali. Homens, mulheres e crianças estão presos ao canavial, muitos já morreram entre as canas ou em decorrência delas.

O caminho entre a casa e o canavial, além de extenso, demonstra também a variedade de cenários pelos quais o homem tem de passar. Vencer aquele caminho, ou seja, completá-lo, é a primeira das lutas diárias de Gregório e de outras centenas de trabalhadores. Assim, ele

Atravessou pinguelas, varjões, beirou encostas e venceu os 8 quilômetros até o lugar de corte naquele dia. Quando chegou, já ouviu o barulho das foices no alto do morro. [...] Queimado há menos de 24 horas para facilitar o corte, ainda tinha tocos fumegantes e brasas, pontos luminosos na madrugada escura. Enquanto não vier o vento, a fumaça vai sufocar, fazer a gente chorar. Mas é melhor o canavial queimado do que seco, emaranhado e cheio de cobras (ANDRADE, 1970, p. 37).

O canavial é queimado com o intuito de tornar aquela tarefa menos perigosa. Em meio a todas as dificuldades do ambiente e do contexto, o que sufoca e faz o homem chorar é a fumaça. Ao mesmo tempo, podemos entender este choro como um pedido de socorro, em silêncio. $\mathrm{O}$ homem, por ser forte e corajoso, não admite a si mesmo reclamar daquele estilo de vida. Mas o corpo fala mais alto, no momento em que o força a chorar em meio à fumaça. $\mathrm{O}$ 
fogo e, consequentemente, a fumaça, ao mesmo tempo em que salvam de alguns perigos, permitem que o homem demonstre seu sofrimento sem o peso do remorso.

Após fazer as observações sobre o caminho e a chegada ao canavial, Gregório encontra um lugar para depositar sua farofa com bacalhau e pega a foice. Em momento anterior, ele já havia feito referência à relação que se estabelece entre a arma e seu braço: são extensões. Assim como os sentimentos do homem em relação à cana, na qual ora ela é a inimiga e ora amiga, o mesmo acontece com a arma. Ao pegar o instrumento, Gregório “[...] olhou a lâmina da foice: inimiga da cana, amiga da gente. Inimiga também, pensou, sentindo no corpo muitos cortes e, em cada um, uma cana espremida para estancar o sangue" (ANDRADE, 1970, p. 37).

Figura 12 - Esquema da relação Personagem-Cana-Foice

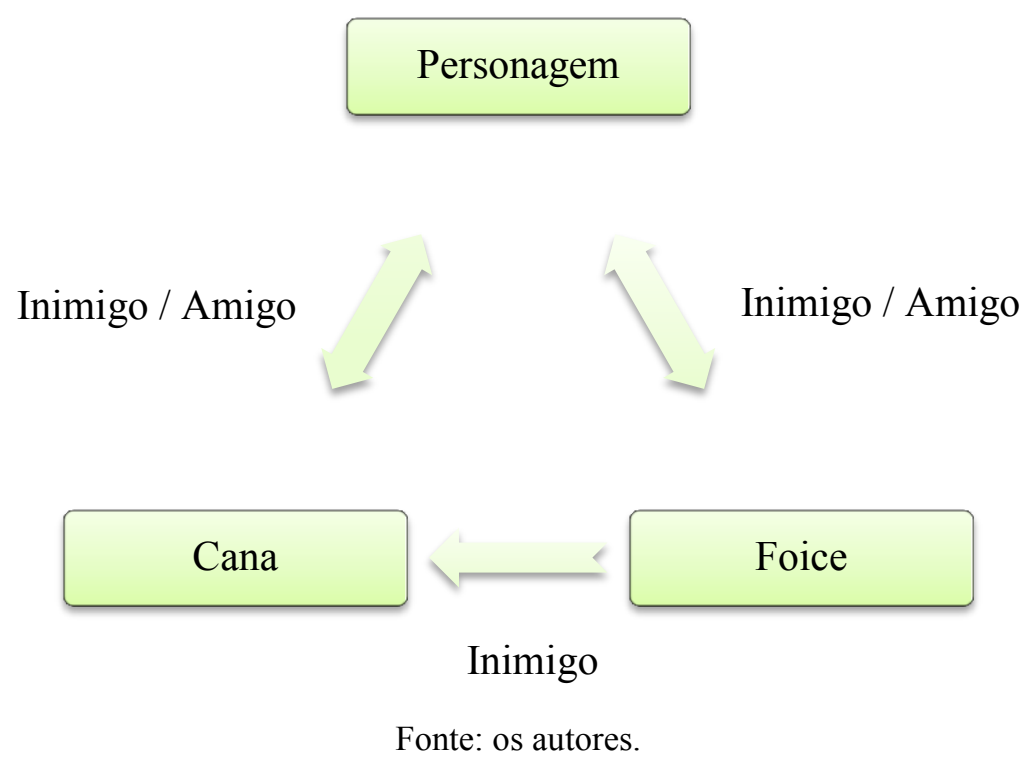

A Figura 12 resume o quadro de relação entre os três principais elementos presentes no canavial: a personagem homem, a cana e a foice. A cana se faz inimiga no momento do trabalho, quando machuca o homem, quando o faz virar uma mina de suor, quando não o recompensa na medida certa de seu esforço. Em contrapartida, é amiga por proporcionar o pouco alimento ao qual tem acesso, e ao estancar o sangue dos cortes realizados pela foice. Quanto à arma, a foice é amiga do homem ao propiciar uma parcela de vingança contra a cana, retirando-a do canavial e levando-a para as máquinas, a fim de torná-la bagaço. Porém, o cansaço e a velocidade com a qual têm de trabalhar faz com que a navalha da foice 
escorregue, machuque o homem. Neste momento, ela se torna inimiga do homem. Por fim, foice e cana travam uma luta entre si, sendo esta unidirecional. Aqui temos apenas uma relação de inimizade entre as duas, uma vez que a lâmina da foice corta a cana e a aniquila.

O trabalho no canavial, além de cansativo e duro, ainda exige a solidão. Exceto quando conta com a ajuda de algum dos filhos, trabalha isolado. Durante todo o percurso de Gregório, já em meio às folhas do canavial, ele encontra com apenas três outros trabalhadores. O primeiro deles é Manuel. Segundo o texto da reportagem, aquele homem bebe e seduz as filhas dos demais trabalhadores, todo sábado de pagamento: Gregório estabelece certa distância para com o sujeito, não querendo falar com ele porque o mesmo não tem um objetivo na vida, vive de beber, cortar e envelhecer (ANDRADE, 1970, p. 38). Gregório irrita-se ao observar o outro.

No entanto, o homem utiliza esta irritação como combustível para começar a cortar. Gregório faz apenas cinco cortes em cada cana, limpando-a e deixando-a no tamanho exato para ser carregada pelos animais de carga até o caminhão. Esta "é a hora de fazer a única conta que aprendeu na vida, conta que faz há 46 anos: três cortes pra limpar e dois pra picar" (ANDRADE, 1970, p. 38). Ao todo, serão 15 mil cortes naquele dia, para cortar uma tonelada e meia de cana, seu objetivo. Mais uma vez, três informações são explicitadas a partir de uma passagem simples de texto: 1) o homem é analfabeto, não sabendo realizar processos matemáticos; 2) Gregório trabalha no canavial desde os oito anos de idade, aproximadamente; e 3) a extensão do processo repetitivo para alcançar a quantidade de canas cortadas suficientes para o sustento da família durante a semana seguinte, exigindo que a personagem realize, ao dia, 15 mil cortes.

Com o amanhecer do dia, os outros trabalhadores se vão fazendo visíveis. Ao todo, cerca de dois mil homens trabalham nas quatorze fazendas pertencentes à usina. Severino, segundo homem vislumbrado em meio ao canavial estava doente no dia anterior e já está de volta ao trabalho. De acordo com Gregório, "Só quando a gente morre é que acreditam na doença que mora no corpo" (ANDRADE, 1970, p. 38). Se a doença mora dentro do ser, ele está descrevendo algo que está ali, no entorno, presente todo o tempo, mas que só é percebido quando tira a vida do homem. Mais uma vez, a personagem se refere aos perigos do meio, ao que convive com ela todo o tempo, esperando o momento de atacar e tirar a vida do homem. Aquelas personagens do engenho nunca estão sadias, pois a doença já fez do corpo delas sua morada. 
Corroborando com o pensamento anterior, Gregório pronuncia uma espécie de grito de guerra, antes de voltar ao trabalho: "- Você derrubou a mata, subiu o morro, passou por cima de tudo! Agora vou passar por cima de você. Você dá o pão, mas também a morte. Toma lá!” (ANDRADE, 1970, p. 38). Nos termos do personagem, a cana seria a culpada de todo o sofrimento causado quando, na realidade, todas as decisões de expandir a cana, de explorar aqueles homens que não têm outra oportunidade, vêm dos donos do engenho. Assim, podemos perceber que, em algumas passagens, quando a cana é tomada como uma personagem mais ampla, pode ser traçado um paralelo entre ela e os donos do engenho, a vontade constante de expandir os negócios, vinda deles.

O próximo intertítulo do texto explicita a relação entre o homem e o canavial: 'inimigo'. Gregório define o brilho que emana da lâmina da foice ao encontrar com os primeiros raios de sol do dia como um brilho de vingança (ANDRADE, 1970, p. 38). Na sequência, o narrador faz referências ao estado físico da personagem e às suas atitudes em meio ao canavial:

E Gregório, corpo encordoado, seco como castanha de caju, subiu cortando, tirando bandeiras, amarrando e fazendo as esteiras de canas; pesando e entregando aos cambiteiros que desciam para a estrada, onde, um atrás do outro, os caminhões esperavam para transportar para a boca voraz da usina (ANDRADE, 1970, p. 38).

Apesar das características de magreza, reflexo da falta de alimento, o homem segue trabalhando com força, sem perder o foco. A usina, em oposição à personagem, é alimentada durante todo o dia. Ela tem uma boca, assim como o homem. No entanto, a primeira é insaciável e depende do homem para ser alimentada. A segunda, por sua vez, disfarça a fome e pensa em todas as necessidades que devem ser alimentadas com o solto conseguido a partir da cana. Ou seja, os braços do homem alimentam tanto a máquina quanto a si mesmo. Em uma passagem posterior, Gregório afirma que seus braços atacam as canas e vão 'comendo' o canavial (ANDRADE, 1970, p. 38), em mais uma utilização do verbo comer com significado diferente do original.

Aqui Gregório afirma que seu inimigo é a cana: "Para melhor trabalhar, começou a sentir raiva. Sentindo raiva, cada cana era um inimigo de quem precisava tomar o pão" (ANDRADE, 1970, p. 38). Naquele campo de batalha, a raiva é o combustível, é o motivo para seguir em frente. E o alimento, o pão, é o troféu. Refletindo acerca deste embate, Gregório pensa nas demais possibilidades de se lidar com a cana: 
- Sei que nos caminhões que transportam não posso, porque não sei choferar. Seria na usina mesmo. Em escritório também não, porque não sei das escritas. É lá, onde a danada é espremida. E não será nas primeiras navalhas, nem no esmagador ou nas primeiras moendas - mas na última, na sétima, onde a cana já virou bagaço e sobe para sustentar as caldeiras. [...] Trabalhar nas máquinas é bom. Domingo, elas param para serem engraxadas, para descansar (ANDRADE, 1970, p. 38).

O homem não vislumbra nenhuma outra possibilidade de trabalho, a não ser com a própria cana. No entanto, vê-se sem muitas possibilidades, uma vez que não estudou. Assim, sobra-lhe, como vingança, ir para a última moenda, onde a cana está no mesmo estado que ele: bagaço. Além disso, traça um paralelo entre a sua vida e a vida da máquina: a segunda tem direito a descanso, a fim de sustentar a produção, ao passo que ele tem de trabalhar todos os dias para garantir o sustento da família.

A terceira das personagens secundárias que Gregório encontra no canavial é Agenor. O homem está sentado em um toco queimado. Todos aqueles que já estão no canavial estão sujos, posto que a fuligem deposita-se sobre seus corpos durante o trabalho. Ao constatar isso, Gregório reflete:

Que vida suja, meu Deus. Passou perto de Agenor, sentado em cima de um toco queimado. Não conseguia distinguir onde terminava a perna e onde começava o toco: a cor era a mesma. No rosto, só os olhos e os dentes mordendo a cana eram brancos.

- Chupando cana no amanhecer, Agenor?

- Alimenta (ANDRADE, 1970, p. 38).

Apesar de referir-se à sujeira encontrada no canavial, Gregório generaliza a situação: a vida é suja. A sujeira é tanto física quanto imaterial. O fato de morarem em uma casa sem energia e sem água, de não terem outro tipo de comida além da farinha e o bacalhau, o pássaro não conseguir cantar em meio à solidão: tudo isso torna a vida suja. Para além da sujeira, homem e canavial se integram, passam a fazer parte de um mesmo corpo, unidos pela cor. Ao não conseguir distinguir onde termina o canavial e onde começa o homem, Gregório admite o grau avançado de integração entre os dois sujeitos. Quanto ao alimento, a usina e o homem usam a cana como combustível. Agenor, e todos os outros, precisam da cana nas mais variadas instância de alimentação: ali no canavial, para seguir cortando; em casa, para alimentar a família com o dinheiro que advém do canavial.

"E Gregório passou por Agenor. Pouco a pouco, enquanto o sol esquentava e cruzava o céu, foi subindo, vencendo o canavial" (ANDRADE, 1970, p. 38). O narrador acelera a 
narrativa temporal, usando o movimento do sol como medida de tempo. Enquanto tem foco no trabalho, Gregório não tem tempo para pensar em mais nada, para ver os companheiros, para conversar. E assim passa o restante do dia no canavial. O verbo vencer, aqui, tem um duplo sentido: tanto faz referência a alcançar o seu objetivo inicial, cortar a tonelada e meia a qual se propunha, quanto a percorrer aquele espaço, de forma que a luta se torna diária.

O homem só vai parar para almoçar quando cumprir a sua meta pessoal de cortes. Gregório afirma ser analfabeto, mas diz que esta condição não faz dele uma pessoa ignorante, que não saiba o quanto deve receber. $O$ homem resume a situação em uma frase: “[...] sei escrever na memória" (ANDRADE, 1970, p. 38). Na semana anterior, não teve o que receber por já ter retirado tudo em vales, mas naquela semana tem dinheiro a receber e é com ele que vai presentear a mulher e levar comida melhor para a família.

O canavial, neste ponto da narrativa, transmuta-se em prisão. Ao longo do texto, as personagens vão deixando claro que não têm outras perspectivas, que depois de estarem ali não há outro lugar para ir. Gregório conclui exatamente isso ao olhar para o canavial:

De repente, Gregório para e olha à sua volta: a cana cercava por todo lado. Abrira uma clareira no meio do canavial queimado e as canas pareciam barras de ferro:

- A gente aqui vive pior que na detenção. Lá, vivem se divertindo: têm banho de sol, cinema, remédio. E aqui? (ANDRADE, 1970, p. 38).

Apesar do exagero aplicado à situação das prisões, especialmente por tratar-se de época de ditadura militar, com forte repressão, ao comparar o modo de vida e trabalho às prisões, a personagem da reportagem compara o seu sofrimento ao que se entende por prisão: ao invés de banho de sol, têm de se proteger do forte sol que chega a $40^{\circ}$ e pode matar; o entretenimento é pouco ou nulo, uma vez que não há tempo para tal; o acesso à saúde é dificultado pela localização do canavial e mesmo pela impossibilidade de deixarem o local e irem procurar por um médico, a doença já mora dentro deles.

O retrato traçado pela personagem, de sua própria situação, demarca a visão que ela tem de si. Apesar de todas as informações de caráter negativo, Gregório ainda mantém o foco, a esperança:

Olha os braços: estão negros. A roupa branca de pano de saco de farinha, rasgada e suja. Os pés molham onde pisam. O corpo era uma mina de água de cima a baixo. Unhas lascadas, couro lanhado, corpo chorando, pensamento cheio de esperança: tirar tonelada e meia. Deixa esse negócio de 
prisão pra lá! Pobre não pensa. Cabra macho, como eu, não sofre. Isso é danação de mulher. É assim que a gente vive [...] Pra que pensar? (ANDRADE, 1970, p. 39).

No entanto, destacamos reflexos do machismo que são expressos no texto: o macho, o homem forte e corajoso, não pode chorar, uma vez que esta é uma característica feminina. $\mathrm{O}$ sofrimento seria um estado que caberia apenas às mulheres. Porém, mesmo que o homem não se permita chorar, seu corpo o faz involuntariamente. Ele diz isso no texto. O corpo chora na medida em que se transforma em suor, produto da situação.

Sabendo da impossibilidade de mudar o cenário, o homem recrimina-se por pensar. Não encontra motivos para pensar, uma vez que o pensamento não mudará a sua situação. Como ele mesmo afirma, não foi delegado aos pobres o poder de pensar. O pobre apenas executa o que lhe foi requerido. No máximo, permite-se ter raiva da ocasião e, por não poder pensar, culpar a cana enquanto vilã, ao invés do dono do engenho ou da ganância do homem.

A figura do administrador da fazenda é posta na narrativa como tendo uma função: transmitir aos demais trabalhadores a mensagem que vem do engenho, a necessidade da máquina de ser alimentada. O próprio Gregório define aquela fala como sendo um recado que vem da 'máquina esfomeada': “- Cana queimada perde sacarose se não for cortada e usinada dentro de 48 horas. Vamos! Não podemos atrasar a produção" (ANDRADE, 1970, p. 39).

Após o recado vindo 'da máquina', Gregório se equipara ao maquinário do engenho, afirmando que mesmo não sendo uma navalha ou máquina, pode destruir, vencer, o canavial:

Olhou a cana em volta e investiu: não sou máquina nem navalha, mas sei cortar. Também sou aço! Toma, infeliz! E Gregório abriu uma vereda e continuou subindo. O corpo arquejando, os olhos embaçados, suor entrando no nariz, no ouvido e na boca: com as mãos segurando e cortando, Gregório conseguiu dar os 15000 cortes e 1 tonelada e meia de canas jaziam amontoadas de baixo até no alto do morro (ANDRADE, 1970, p. 39).

O corpo reclama, expressa os sentimentos do homem, os quais não podem se expressos por ele mesmo, de forma consciente. Mesmo com toda a dificuldade, a personagem chega ao alto do morro, vence a sua batalha diária, derrota o canavial, atinge seu objetivo inicial. E as canas, como ele, estão derrotas ao longo do caminho. Apesar de ganhar aquela batalha, o homem arqueja, está 'morto', de cansaço. Ao final da batalha, ambos estão mortos, cada um a sua maneira. 
- Ganhei bem ganhado meus três cruzeiros e quarenta e quatro centavos por um dia de serviço.

Satisfeito e cheio de esperanças, começou a descer o morro (ANDRADE, 1970, p. 39).

O trecho acima é o encerramento da reportagem. Após a batalha diária, o homem volta para casa com a sensação de que fez o que deveria ser feito, cumpriu o seu papel. O dia de serviço rendeu-lhe NCr\$3,44. A fim de traçarmos um paralelo, o preço de capa da edição de número 46 de Realidade, na qual esta reportagem foi publicada, era de $\mathrm{NCr} \$ 2,50$.

Figura 13 - O canavial esmaga o homem, Revista Realidade, nº 46, jan. 1970, p. 38-39

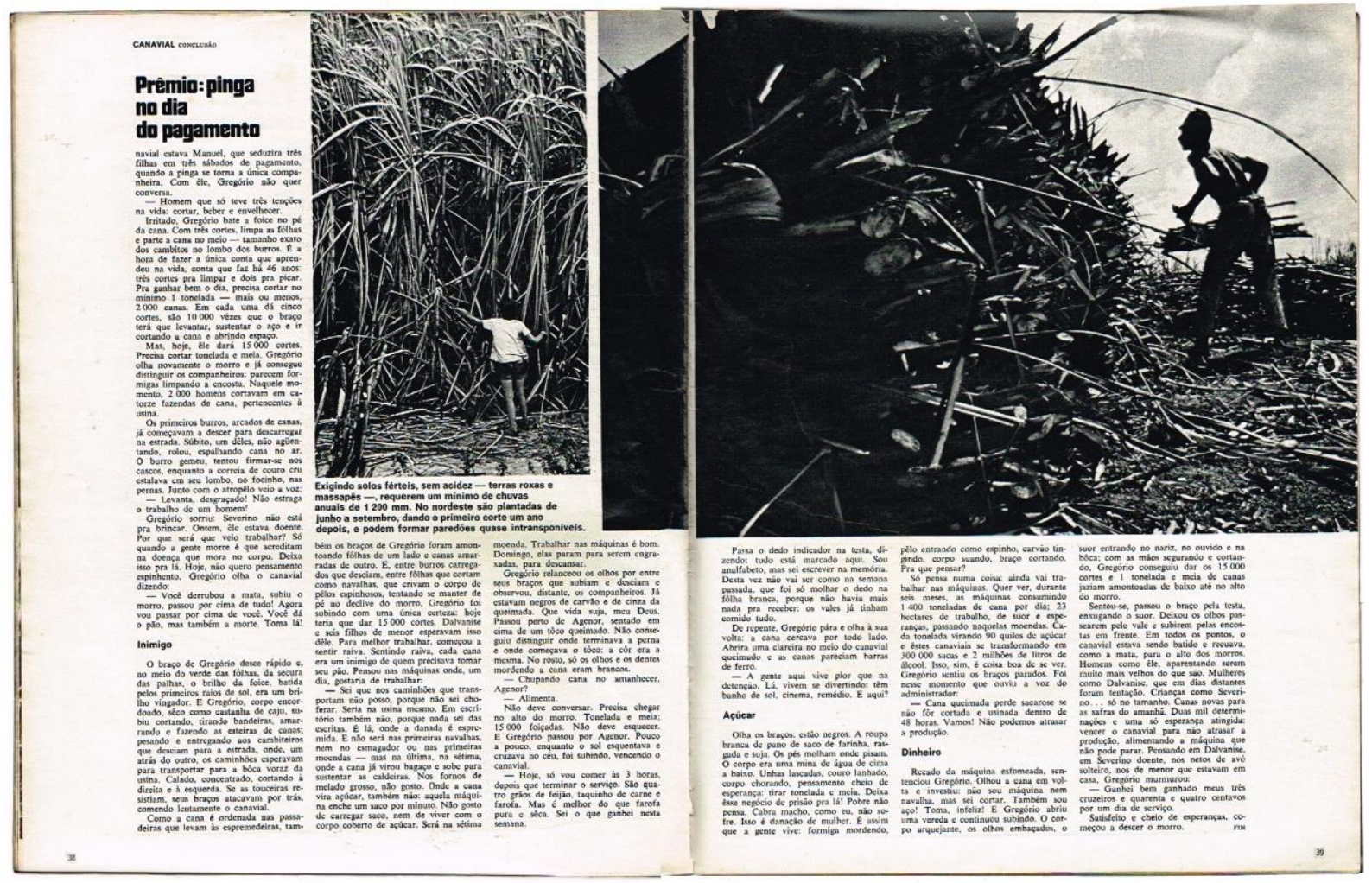

Fonte: Acervo do Grupo de Pesquisa Estudos Fotográficos (CNPq/UFCA)

A última página da reportagem traz ainda duas fotografias, ambas em preto e branco (Figura 13). Na primeira delas, uma criança vasculha o canavial. A legenda da fotografia faz referência aos possíveis paredões que o canavial pode formar, sendo os mesmos praticamente intransponíveis. A criança está justamente diante de um desses paredões, que podem atingir até três metros de altura. Se lermos esta fotografia como uma releitura, por parte do narrador, do futuro e do presente da criança, veremos que as perspectivas da mesma a ligam ao 
canavial. Olhando através do emaranhado de cana, o menino não pode distinguir nada além disso para o seu futuro naquele lugar.

$\mathrm{Na}$ segunda fotografia, um homem lida com as canas já cortadas e amarradas. Sem camisa e utilizando chapéu, segue o padrão de indumentárias apresentadas pelas demais fotografias. Para terminar a reportagem, o homem venceu o canavial, naquela batalha cotidiana, e junta os pequenos troféus de sua vitória. Mesmo com o sofrimento, o homem brilha em função do suor que o canavial the faz aflorar da pele, carrega uma expressão corporal que remete ao orgulho pelo trabalho realizado. 
CAPÍTULO VI

\section{NARRATIVA III: POVO CARANGUEJO}

A reportagem intitulada Povo Caranguejo foi publicada na revista Realidade em março de 1970, com texto de Audálio Dantas e fotografias de Maureen Bisilliat. A mesma relata a vida difícil dos cerca de mil moradores da aldeia de Livramento, distante 20 quilômetros da cidade de João Pessoa, na Paraíba. Ao apresentar as personagens da sua reportagem, o repórter relata o cotidiano que as pessoas da aldeia levam caçando caranguejos com as próprias mãos, enfiados na lama até o pescoço, numa luta pela sobrevivência em que o caranguejo sempre perde, mas o homem ganha muito pouco.

No livro Tempo de Reportagem, publicação que reúne trabalhos de Audálio Dantas e suas reflexões sobre os bastidores da apuração para tais reportagens, o jornalista descreve como ambos os repórteres vivenciaram o Povo Caranguejo:

Conheci o mangue por dentro, seguindo os passos de velhos e experientes caçadores de caranguejo. Comigo ou explorando outras partes do pântano, a fotógrafa Maureen Bisilliat. Ela só temia uma coisa: que a lama atingisse as lentes de sua máquina, seu segundo olhar (DANTAS, 2012, p. 114).

Audálio Dantas (2012) ainda descreve alguns detalhes técnicos da viagem: os dois repórteres ficaram hospedados em João Pessoa durante uma semana, mas iam ao povoado, de carro, todos os dias; ele foi ao mangue três vezes; para proteger os pés, utilizou o mesmo tipo de proteção que o povo do mangue, pedaços de sola amarrados aos pés, o que não foi feito pela fotógrafa.

Ao abrir a revista nas primeiras páginas da reportagem (Figura 14), a expressividade da fotografia capta a atenção do leitor. A imagem de abertura ocupa três quartos da página dupla e nos apresenta a seguinte representação: um ser humano com traços femininos, rosto envelhecido, parcialmente mergulhado na lama do mangue, com um cachimbo entre os lábios. 
A imagem estabelece com o texto escrito, e de forma mais estreita com o título, uma similaridade na construção dos significados da reportagem, de forma que ambas as linguagens reforçam o sentido sobre a vida dura daquela comunidade e, especialmente, sobre as características que aproximam os seres humanos e o caranguejo: a sobrevivência em meio à lama.

A fotógrafa Maureen Bisilliat, em entrevista cedida ao projeto Realidade: $o$ fotojornalismo autoral de uma revista, relatou como encontrou e fotografou o grupo de mulheres catadoras de caranguejo que, posteriormente, dariam origem ao ensaio intitulado Caranguejeiras. Das fotografias realizadas junto a este grupo, uma estampa a capa deste número da revista, outra abre a reportagem e mais uma pode ser encontrada no interior do trabalho. Bisilliat relata: “[...] de repente eu escuto assim uns, uns barulhos assim como de passarinho tic, tic, tic... Eram mulheres falando, rindo e chamando, e tal, tal, tal... e segui eles. E me vi dentro dessa espécie de espaço na lama onde que elas estavam catando" (BISILLIAT, 2013).

Figura 14 - Povo Caranguejo, Revista Realidade, nº 48, mar. 1970, p. 102-103
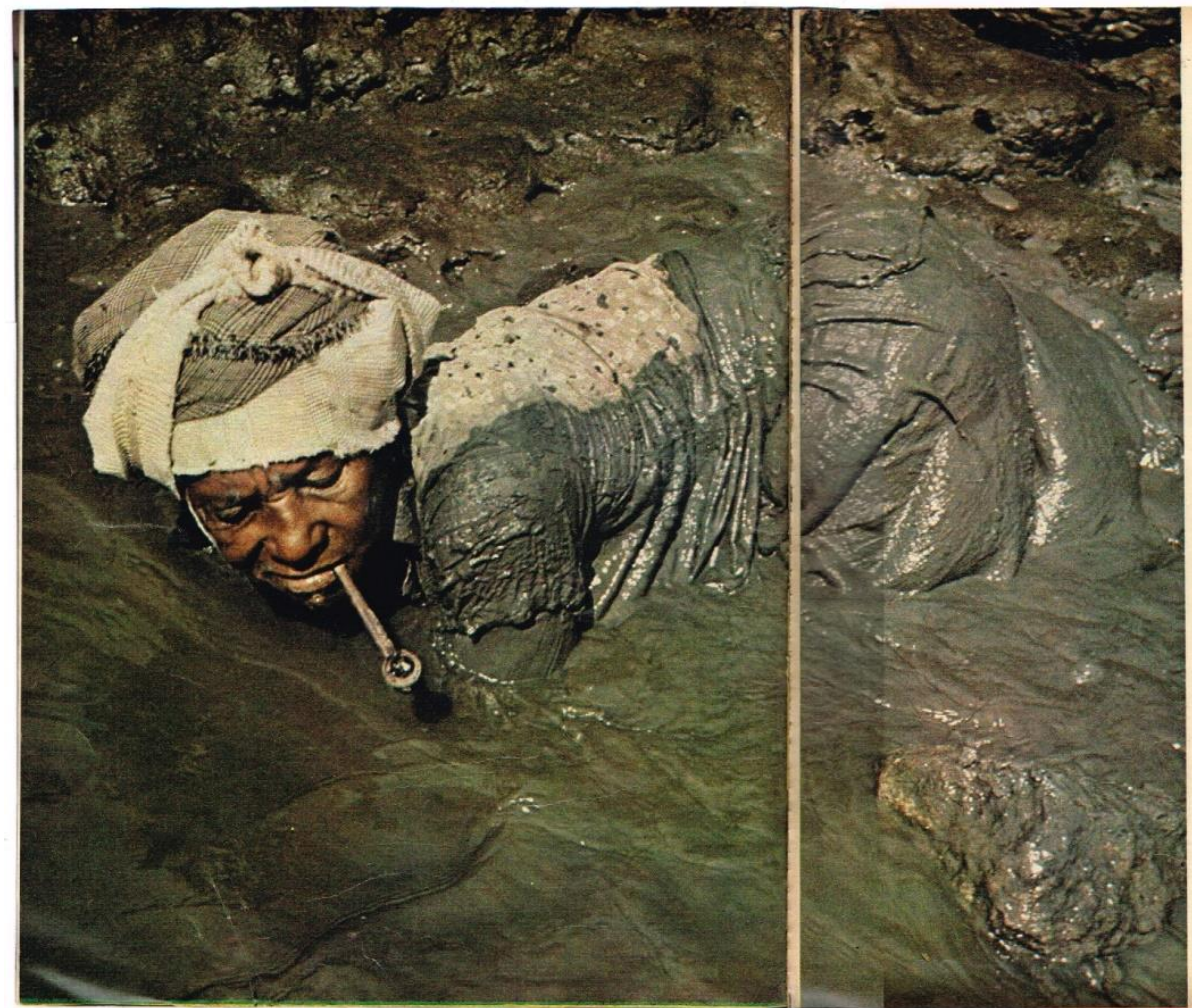

\section{POVO
CARANGUEJO}
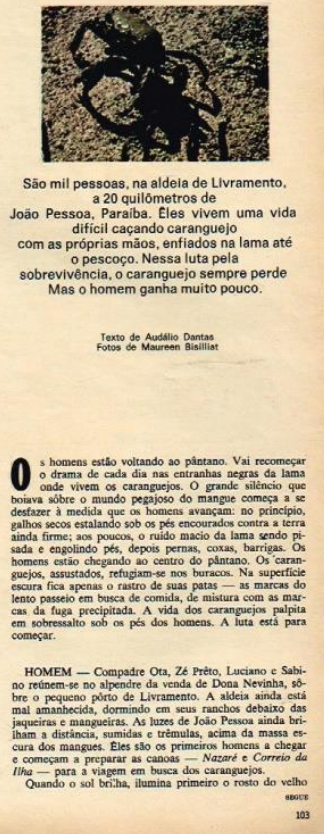

Fonte: Acervo do Grupo de Pesquisa Estudos Fotográficos (CNPq/UFCA) 
O narrador do texto escrito dá início à narrativa descrevendo aquela ação como algo rotineiro, transmitindo ao narratário a sensação de que está dando sequência a algo já começado anteriormente: o texto tem início em um dia qualquer da comunidade, sem que nenhum fato fora do comum tenha acontecido. O primeiro parágrafo do texto nos dá informações sobre o espaço no qual se desenvolve a narrativa, descrevendo-o em termos da luta que está para ser travada, mais uma vez, entre o homem e o caranguejo:

Os homens estão voltando ao pântano. Vai recomeçar o drama de cada dia nas entranhas negras da lama onde vivem os caranguejos. O grande silêncio que boiava sobre o mundo pegajoso do mangue começa a se desfazer à medida que os homens avançam: no princípio, galhos secos estalando sob os pés encourados contra a terra ainda firme; aos poucos, o ruído macio da lama sendo pisada e engolindo pés, depois pernas, coxas, barrigas. Os homens estão chegando ao centro do pântano. Os caranguejos, assustados, refugiamse nos buracos. Na superfície escura fica apenas o rastro de suas patas - as marcas do lento passeio em busca de comida, de mistura com as marcas da fuga precipitada. A vida dos caranguejos palpita em sobressalto sob os pés dos homens. A luta está para começar (DANTAS, 1970, p. 103).

O narrador adjetiva o embate que está para acontecer em uma palavra: drama. Tal termo está carregado de sentidos. Não é um drama passageiro, pontual, é algo que está entranhado na vida daquela comunidade e que se repete regularmente. A expressão 'drama de cada dia' traz ainda um pressuposto de continuidade, de cujas implicações o narrador tratará ao longo de todo o texto.

Desde este ponto, o homem começa a ser descrito como o inimigo, que está invadindo o espaço do caranguejo, assustando-o. Subjugados ao tamanho físico superior e à habilidade do homem, os mesmos ficam sobressaltados, pois antecipam a própria captura, ou a morte. Destacamos aqui uma observação: as frações do corpo deste homem se sobressaem na narrativa em relação ao todo, ele é mais vezes descrito em termos de fragmentos que de forma completa - nos momentos de confronto direto com o animal.

A introdução é encerrada com a frase de efeito "a luta está para começar" (DANTAS, 1970, p. 103). O narrador deixa claro que vai descrever um embate. Aqui localizamos a intriga da narrativa. A luta, mais que entre o homem e o caranguejo, ou entre o homem e o mangue, assume uma dimensão que extravasa os limites da palavra: é a luta pela sobrevivência na pobreza, na miséria. 


\subsection{Uma narrativa, duas personagens: o caranguejo e o homem como protagonistas}

Dantas (2012) afirma que ainda durante seu percurso pelo mangue se perguntava como escreveria a reportagem, uma vez que a experiência exigia mais que o lide comum, então utilizado. Desta forma, ele relata:

Comecei a "construir" o texto ao imaginar o drama dos bichos sob a lama. Pensava em como eles reagiam à prisão. Mas esse pensar era incerto como o chão coberto de lama do mangue. Surgiu, então, a ideia, que só se completaria na redação: montar um "diálogo" entre caça e caçador (DANTAS, 2012, p. 115).

Assim, as duas personagens dessa disputa, HOMEM e CARANGUEJO ${ }^{37}$, recebem no texto espaços diferenciados, marcados pela edição. Alternadamente, cada um é o foco daquele fragmento da narrativa. Somados os pequenos textos, temos a narrativa de dois dias de trabalho, ou de luta, no mangue. O primeiro é de pesca, afundados na lama até o pescoço, o segundo é de venda a preços variantes, no mercado da capital do estado. A parcela referente ao HOMEM está em fonte normal, com palavras destacadas com formatação em itálico, ao passo que a parcela referente ao CARANGUEJO encontra-se em itálico, com palavras destacadas em formatação simples. Os textos independentes são separados por espaços em branco, causando descontinuidades entre os blocos.

A primeira personagem a entrar na luta é o HOMEM. Na verdade, um grupo deles. O dia mal começou e Compadre Ota, Zé Prêto, Luciano e Sabino já se reúnem à venda de Dona Nevinha. O narrador destaca que "as luzes de João Pessoa ainda brilham a distância, sumidas e trêmulas, acima da massa escura dos mangues" (DANTAS, 1970, p. 103). A partir do excerto anterior podemos perceber a oposição feita ao pântano, região escura, mal definida, submersa na incerteza proveniente da pobreza e da miséria, em oposição à capital, localidade iluminada, esclarecida, que está acima, para onde se vai quando se pode fugir.

O mais velho daqueles catadores de caranguejo é Sabino, o 'velho' Sabino. Ele tem “[...] setenta anos de vida, sessenta de luta na lama [...]” (DANTAS, 1970, p. 104). É chamado pelo narrador de 'patriarca dos pântanos', numa referência a sua ampla experiência naquele ambiente: pegava caranguejos desde menino, com uma ratoeira, um brinquedo para os

\footnotetext{
${ }^{37}$ A montagem da reportagem pela Editoria de Arte colocou as palavras HOMEM e CARANGUEJO, assim grafadas, antes do texto referente a cada uma das personagens, como forma de localizar o leitor na narrativa. Aqui utilizaremos esta mesma marcação.
} 
moradores de Livramento naquela idade. E, à época presente da narrativa, o mesmo brinquedo de seus netos.

Sabino é descrito como um sujeito forte, respeitado pelos demais companheiros justamente por esta sua característica. Além disso, não tem medo de trabalhar e tem coragem para enfrentar os perigos daquele labor: "Ele vai ao mais fundo do mangue, às moradas mais escondidas dos caranguejos. Se soubesse fazer contas, veria o resultado de seus sessenta anos de trabalho: mais de 1 milhão e meio de caranguejos arrancados da lama" (DANTAS, 1970, p. 104). Além de nos dar indícios do quanto trabalha um pescador de caranguejo - trazendonos uma estimativa de animais apanhados em uma vida de caça - e reforçar a sua relação de inimigo do caranguejo - que o retira sem consentimento de seu habitat -, essa passagem nos deixa antever outra informação: o velho Sabino é analfabeto. Naquela região, há poucas oportunidades para aprender a ler ou escrever.

Sabino também é dono de barco, como poucos ali. Naquela viagem serão utilizadas duas canoas, Nazaré e Correio da Ilha. A primeira é a de Sabino, na qual será ajudado por Zé Preto. Na segunda, viajarão compadre Ota e Luciano. Ambas irão rumo à Ilha do Tiriri, pedaço de terra entre dois braços do rio Sanhauá, onde está localizado o mangue do Bueiro, um dos mais fartos em caranguejo da região.

No fundo de cada uma das canoas estão os utensílios, que o narrador chama de apetrechos, a serem utilizados durante a pesca: um cesto com embiras ${ }^{38}$, material utilizado para unir os caranguejos nas chamadas cordas; uma cabaça ${ }^{39}$ com água; uma cuia ${ }^{40}$; e o boi de fogo fumaçando. Este último é “[...] uma lata de tamanho médio em que são acesas pequenas achas de lenha, para espantar mosquito e acender cachimbos, com gosto" (DANTAS, 1970, p. 104). Desta forma, o homem vai contornando os percalços impostos pela natureza, ajustandose a partir da sabedoria popular à vida difícil do mangue. O cachimbo também se mostra um acessório importante no momento de lidar com o ambiente: mesmo afundados na lama, ele está ali, entre os lábios, alterando o sabor da boca e o aroma do local.

Partindo de algumas brincadeiras realizadas entre as personagens, o narrador tece críticas à situação social na qual se encontra aquela comunidade. Segue um exemplo:

\footnotetext{
${ }^{38}$ Nome comum a arbustos timeleáceos que produzem boa fibra na entrecasca, produzindo cipó usado para amarrar.

${ }^{39}$ Vasilhame feito a partir do fruto seco do porongo.

${ }^{40}$ Vaso feito a partir do fruto da cuieira, esvaziado do miolo. Também pode ser chamado de cuité.
} 
A comida: não há comida na canoa, que o trabalho no mangue é duro, não deixa tempo. Na volta, há uma panela com água no fogo, esperando os caranguejos, ao lado de outra panela cozinhando feijão. Compadre Ota brinca com Sabino:

- Tem carne hoje, Sabino?

- Home, deixe de pilhéria. Já viu pobre comê carne? (DANTAS, 1970, p. 104).

$\mathrm{Na}$ sequência do texto, após já tê-los caracterizado na narrativa enquanto pobres, utilizando-se da fala de uma das personagens para tal, o narrador descreve aquela afirmativa como um exagero, uma vez que na feira do último sábado o próprio Sabino comprou um quilo de carne. No entanto, este tipo de compra exige escolhas: teve de comprar uma quantidade inferior à necessária para a família de farinha e feijão, bem como não comprou uma camisa da qual estaria precisando (DANTAS, 1970, p. 104).

Em poucas palavras, o texto faz aflorar um resumo da relação dos pescadores naquele momento: "Assim eles passam o tempo a caminho do mangue: brincando com a própria miséria" (DANTAS, 1970, p. 104). O termo miséria, referência ao estado de penúria no qual vivem aqueles pescadores, faz parte de um jogo de palavras que a une ao verbo brincar, termo com sentido positivo. A brincadeira toma a própria condição do ser e os problemas acarretados por ela como subsídio para as piadas. Nos termos do autor, "é preciso brincar, dizer asneiras, que logo todos eles estarão chafurdando na lama, em luta de morte contra os caranguejos" (DANTAS, 1970, p. 104). Como repetido ao longo do texto, nenhum dos dois lutadores desta guerra ambientada no mangue paraibano, ganha. O homem chafurda na lama em busca do animal. A luta torna o homem parte daquele ambiente, integra-o e também o humilha.

Como podemos ver na Figura 15, há um fragmento de texto em destaque nesta página: “Corda, fumo, facas, tudo certo. Vai começar a caçada no pântano". É costume da edição da revista trazer um olho por página. Em algumas situações, os mesmos são tratados como legendas para as fotografias. Neste caso, tem relação direta com o primeiro texto, referente ao HOMEM, que está se preparando para a viagem e se dirigindo ao mangue, bem como contribui para criar o clima de início de batalha. Para a edição desta reportagem, em todas as páginas duplas o olho está localizado em posição semelhante: no topo, centralizado.

Na página 104, temos a primeira aparição do CARANGUEJO enquanto protagonista da narrativa. Lemos o texto a partir de seu ponto de vista. Ele não narra em primeira pessoa, mas o narrador constrói o acesso a seus sentimentos, pensamentos e angustias. Um fluxo de consciência entre o narrador e o animal. Antes de o homem chegar, "na solidão e no silêncio 
sombrios do lamaçal, caranguejo é rei" (DANTAS, 1970, p. 104). Nos períodos de seca, quando não há chuva e, assim, as folhas não caem dos mangues, os caranguejos emitem um chiado de fome, acompanhado de uma espuma amarela que sai de suas bocas. O seu mundo é este: lama, raízes, água e chiado.

Figura 15 - Povo Caranguejo, Revista Realidade, nº 48, mar. 1970, p. 104-105

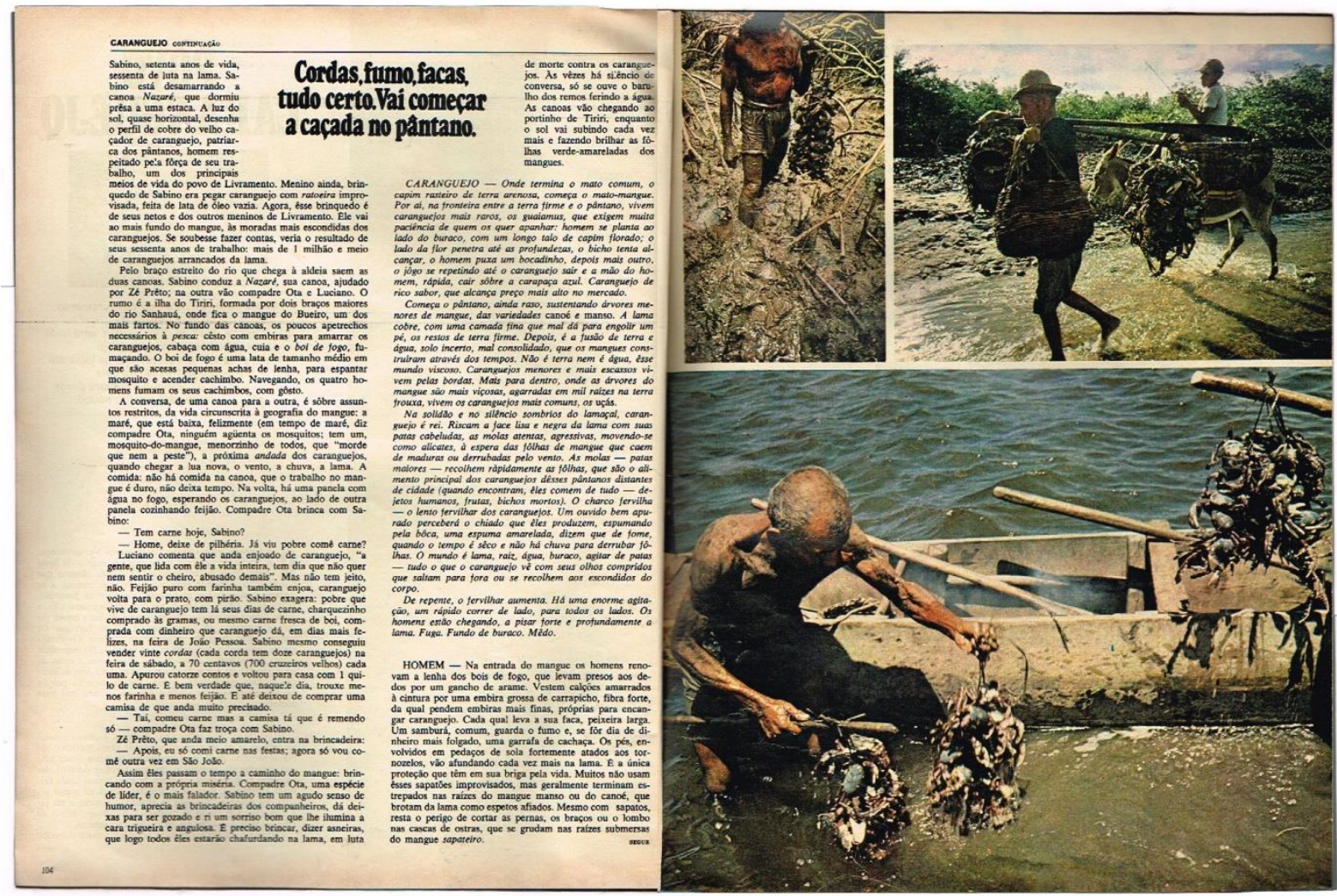

Fonte: Acervo do Grupo de Pesquisa Estudos Fotográficos (CNPq/UFCA)

Neste ponto do texto ainda observamos a introdução de mais um elemento que nos conta acerca da relação do lugar com a urbanidade: aqueles pântanos estão distantes das cidades. Tal fato torna o caranguejo da reportagem mais puro, uma vez que não tem contato com os dejetos produzidos pelo homem, quer natural, quer artificialmente.

Os fragmentos de texto atribuídos ao CARANGUEJO são mais romantizados, em relação aos referentes ao HOMEM, estes com maior carga informativa. Tragamos como exemplo a introdução à luta, fechamento deste trecho: "De repente, o fervilhar aumenta. Há uma enorme agitação, um rápido correr de lado, para todos os lados. Os homens estão chegando, a pisar forte e profundamente a lama. Fuga. Fundo de buraco. Medo" (DANTAS, 
1970, p. 104). As pausas do final trazem ao leitor uma sensação de descontinuidade que reforça a situação do caranguejo, encurralado em sua própria casa.

As três fotografias presentes na página ímpar, como pode ser visto na Figura 15, retratam os catadores de caranguejo em momentos posteriores ao embate, quando o homem já está em poder das cordas, o caranguejo já foi capturado. Na primeira delas, na parte superior esquerda, um ser humano, de características masculinas, segura uma vara da qual pendem cordas de caranguejos da ponta frontal. O homem encontra-se parcialmente imerso na lama do manguezal, mas pode-se perceber que sua atividade lhe exigiu ir mais fundo: há resquícios de tom amarronzado por todo o corpo, de forma mais acentuada nas pernas e braços, mas podendo ser observados também no tórax.

Esta primeira imagem não permite ver o rosto do pescador, algo que se repete em outras ocasiões ao longo da reportagem. Tal opção nos direciona o olhar especialmente para a ação, para o modo como o corpo se integra àquele ambiente. A opção por utilizar algumas fotografias coloridas também traz um elemento interessante: os ambientes são, em si, monocromáticos. A integração homem-mangue se dá em cores e ações.

A segunda fotografia, na parte superior direita da página ímpar, representa dois homens carregando suas cordas de caranguejos. Esta fotografia foi tomada na parcela de terra em que o mangue interage com o rio. Um dos homens, o mais velho, caminha com os pés dentro da água corrente, ao passo que o segundo está montado em um animal de carga, um jumento. Ambos estampam expressões tristes, cansadas, deixando transparecer o quão esgotante é o trabalho de caça ao caranguejo.

A terceira imagem, tomando mais da metade da página simples, nos apresenta um dos pescadores lavando as cordas de caranguejo no rio, ao lado da canoa. Amarrados, os caranguejos são sistematicamente mergulhados na água salobra do rio, retirando deles a lama que ainda lhes restava do mangue. Sua cor azulada e suas formas definem-se. A imagem deixa ver, ainda, que há outro pescador ao lado, não tendo sido representado por inteiro na fotografia, mas a vara a qual segura ali está. Isso acontece porque o barco é dividido e o dono o freta a mais um catador.

O texto volta a focalizar no HOMEM. Na entrada do mangue, em um último preparativo para a caçada, eles renovam a lenha dos bois de fogo. Na primeira das três fotografias (Figura 15) é possível ver, ao lado do pescador, a pequena lata e a fumaça que dela emana. Eles a levam presa aos dedos por um pedaço de arame. Além disso, 
Vestem calções amarrados à cintura por uma embirra grossa de carrapicho, fibra forte, da qual pendem embiras mais finas, próprias para encangar caranguejo. Cada qual leva a sua faca, peixeira larga. Um samburá, comum, guarda o fumo e, se for dia de dinheiro mais folgado, uma garrafa de cachaça (DANTAS, 1970, p. 104).

Os pés são envoltos em sola e vão afundando, gradualmente, na lama. Esta "é a única proteção que têm em sua briga pela vida" (DANTAS, 1970, p. 104). O narrador explicita que aquele momento é de fundamental importância para a existência dos homens, uma vez que dali advém o sustento da comunidade. Material e mesmo alimentar. Lutam contra os caranguejos como lutam pela vida. Há uma transferência de significado: a dificuldade da sobrevivência é transfigurada no caranguejo e na dificuldade de alcançá-lo. No entanto, depende apenas do homem vencer aquela briga. Neste contexto, o homem necessita de proteção, pois tanto o caranguejo quanto o próprio mangue já trazem as suas armas naturais.

Os caranguejos vivem em verdadeiros labirintos formados pelas raízes do mangue. Quando atingem tal região do manguezal, os homens já estão com lama pela cintura. Os caranguejos com interesse comercial se escondem no fundo dos buracos. Já os aratus, espécie menor e não procurada, passeiam indiferentemente na superfície. Luciano e Sabino fazem observações sobre tal diferença entre os bichos. Luciano diz: “- É a ciença dos bichos. Eles sabe que não são perseguido, não carece se escondê como os outros" (DANTAS, 1970, p. 107). A reportagem transcreve, além das falas, os pensamentos das personagens. Vejamos a reação de Sabino ao observar os caranguejos: ele

[...] vai mais devagar, jogando o seu velho corpo com certa dificuldade pelo meio das grades do sapateiro. Tapou uma corda, se muito, mas vai alegre, filosofando: não sabe como, mas esses bichos cheios de pernas pensam do jeito da gente. Senão, como é que eles sentem que estão sendo caçados? Uma ciência (DANTAS, 1970, p. 107).

\subsection{O embate entre as personagens: a luta pela vida}

O trabalho tem início com a chamada tapagem, quando os homens identificam os buracos dos caranguejos em meio à lama e os obstruem com a ajuda de pernas e braços. "Em pouco tempo, os homens são estátuas de lama, parece que fazem parte do meio escuro e pegajoso" (DANTAS, 1970, p. 107). Este trecho da narrativa dialoga diretamente com a fotografia que integra a página (Figura 6): um ser humano com características femininas, 
jovem, mergulhado até a altura da cintura na lama, com marcas de barro molhado até as têmporas.

Figura 16 - Povo Caranguejo, Revista Realidade, nº 48, mar. 1970, p. 106-107

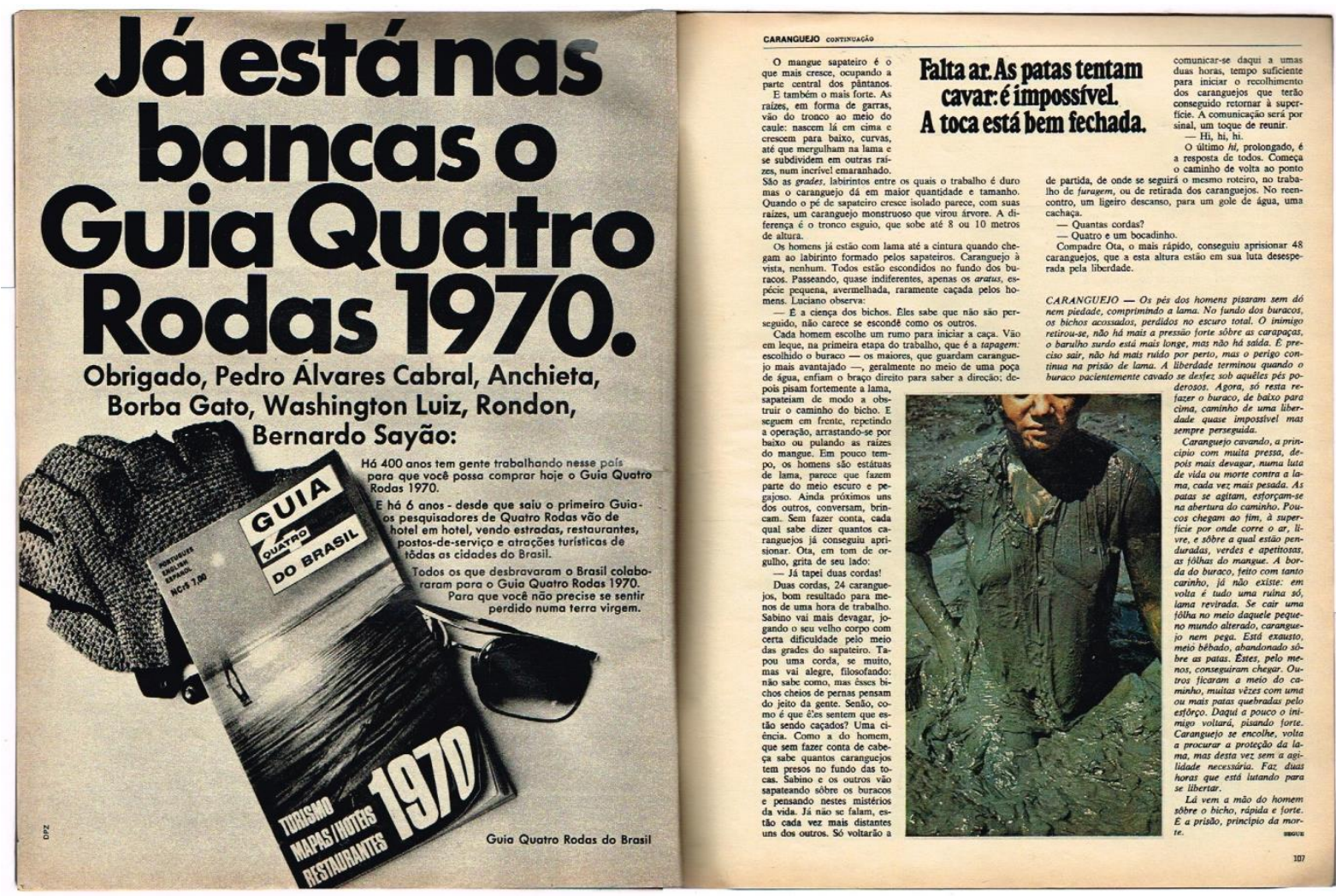

Fonte: Acervo do Grupo de Pesquisa Estudos Fotográficos (CNPq/UFCA)

A parte inferior da imagem indica um leve movimento de pernas da retratada, o qual exige esforço. Mais uma vez identificamos a característica monocromática possibilitada pelo mangue, bem como os olhos da personagem não fazem parte da parcela revelada pela imagem. Uma verdadeira estátua de lama, a garota leva a mão à cintura, mesmo que de forma involuntária. A textura da massa de lama nos transmite a impressão de que outros corpos passaram por ali, quer seres humanos ou animais: está revirada, com nuances que formam uma espécie de conglomerado de ondas. Velhos ou jovens, toda a comunidade perpassa a cultura da lida com o caranguejo. Nas fotografias e no texto há referências a pessoas das mais diversas idades. Aquela comunidade depende intimamente do caranguejo.

Os homens não sabem a quantidade de animais que já aprisionaram, mas contam-nos em cordas. Sabem exatamente quantas cordas taparam. Em menos de uma hora de trabalho, compadre Ota já tapou duas cordas, ou seja, aprisionou 24 caranguejos. Cerca de duas horas 
depois retornam, realizando a furagem: furando a lama exatamente no local tapado em busca do caranguejo que tentava voltar à superfície. Lembram exatamente todos os locais por onde passaram.

O próximo texto referente ao CARANGUEJO tem início com uma leitura do mesmo acerca da tapagem:

Os pés dos homens pisaram sem dó nem piedade, comprimindo a lama. No fundo dos buracos, os bichos acossados, perdidos no escuro total. $\mathrm{O}$ inimigo retirou-se, não há mais a pressão forte sobre as carapaças, o barulho surdo está mais longe, mas não há saída. É preciso sair, não há mais ruído por perto, mas o perigo continua na prisão de lama. A liberdade terminou quando o buraco pacientemente cavado se desfez sob aqueles pés poderosos. Agora, só resta refazer o buraco, de baixo para cima, caminho de uma liberdade quase impossível, mas sempre perseguida (DANTAS, 1970, p. 107).

O homem é o inimigo do caranguejo. Assim que o mesmo se aproxima, o ruído, a pressão e a mudança física do ambiente o tiram de sua cotidianidade e o obrigam a ir à superfície, a fugir. No entanto, a fuga o leva em direção ao homem. Neste fragmento, podemos fazer alguns paralelos com a situação na qual vivia uma parcela dos brasileiros que discordava da ditadura militar naquele momento.

Os pés que pisam sem dó nem piedade, tal como o relatado sobre a violência contra os presos políticos, por exemplo, comprimem a lama, em uma possível alusão à tortura. Dizemos isso, pois, naquele momento histórico vivia-se sob a égide das constantes prisões políticas, tendo como foco jornalistas e estudantes universitários, entre outros brasileiros. Além disso, os mesmos pés são chamados de poderosos. Da mesma forma, o governo abusava do poder, especialmente por meio dos Atos Institucionais, e da força, por meio de organizações como a Operação Bandeirantes (Oban), articulada em 1969 no estado de São Paulo. Nesta passagem, os pés estão em foco, não o homem. O poder está em uma parte específica dele, não no sujeito completo.

Para completar a reação do caranguejo ao ver seu buraco tapado, o narrador trata da liberdade, algo dado como impossível, mas mesmo assim perseguido pelo animal, que ainda se identifica enquanto morador daquele lugar, tendo direito sobre aquela parcela de lama. Da mesma forma, os brasileiros que já se viam reprimidos, especialmente após a promulgação do Ato Institucional $\mathrm{N}^{\circ} 5$, perseguiam a liberdade de expressão e, especialmente, política, também num patamar de impossibilidade, uma vez que os órgãos repressores se fortaleciam. 
A luta, intriga do texto, que numa primeira instância é entre o homem e o caranguejo, após a tapagem passa a ser direta entre o caranguejo e a lama, uma vez que ele precisa chegar à superfície. A modificação realizada pelo homem implica numa luta exaustiva e mortificante para o animal. A lama, antes parte integrante do espaço, aqui tem características de sujeito na narrativa.

Poucos chegam ao fim, à superfície por onde corre o ar, livre, e sobre a qual estão penduradas, verdes e apetitosas, as folhas do mangue. [...] Se cair uma folha no meio daquele pequeno mundo alterado, caranguejo nem pega. Está exausto, meio bêbado, abandonado sobre as patas. Estes, pelo menos, conseguiram chegar. Outros ficaram a meio do caminho, muitas vezes com uma ou mais patas quebradas pelo esforço (DANTAS, 1970, p. 107).

O olho desta página (Figura 16), "Falta ar. As patas tentam cavar: é impossível. A toca está bem fechada" (DANTAS, 1970, p. 107), destaca a angustia do caranguejo na tentativa de voltar à superfície. O final da página foi diagramado de forma que coincide com o final do texto referente ao caranguejo. Nas últimas linhas, um momento de tensão onde mais um dos membros do corpo do homem surge como ameaça para o animal, neste caso, a mão: "Lá vem a mão do homem sobre o bicho, rápida e forte. É a prisão, princípio da morte" (DANTAS, 1970, p. 107).

O princípio da morte para o caranguejo é a esperança da vida para o homem. Ao conseguir capturá-lo, vê nele o sustento para a família, as compras que poderão ser feitas na feira no dia seguinte, com o dinheiro conseguido a partir da venda do caranguejo, ali mesmo.

$\mathrm{O}$ ato de furar despende uma quantidade menor de tempo que tapar, no entanto, é mais doloroso, para ambas as personagens. O homem avança, o caranguejo defende-se como pode, com suas garras afiadas. Aqui temos o primeiro encontro, efetivo, entre nossas duas personagens:

Furar, enfiar o braço na lama a procura dos que não conseguiram chegar à superfície, é trabalho mais demorado e, muitas vezes, doloroso: os dedos dos homens encontram as unhas afiadas dos caranguejos, ferem-se e sangram. O sangue nem chega a ser visto, perde-se no escuro da lama. Mas o caranguejo vem, e aumenta a corda (DANTAS, 1970, p. 108).

O sangue, o que é vital ao homem, perde-se na luta inglória, em meio ao mangue: a lama, que agora toma a parte externa de seu corpo, e aquilo que lhe é interno, invertem os papéis. O homem torna-se uma estátua de lama, ao mesmo tempo em que a lama se alimenta 
do sangue do homem. Na Figura 17 podemos observar o olho desta página: "A mão encontra garras afiadas. O sangue fica embaixo da lama" (DANTAS, 1970, p. 108), um eco ao que estamos tratando.

Figura 17 - Povo Caranguejo, Revista Realidade, no 48, mar. 1970, p. 108-109

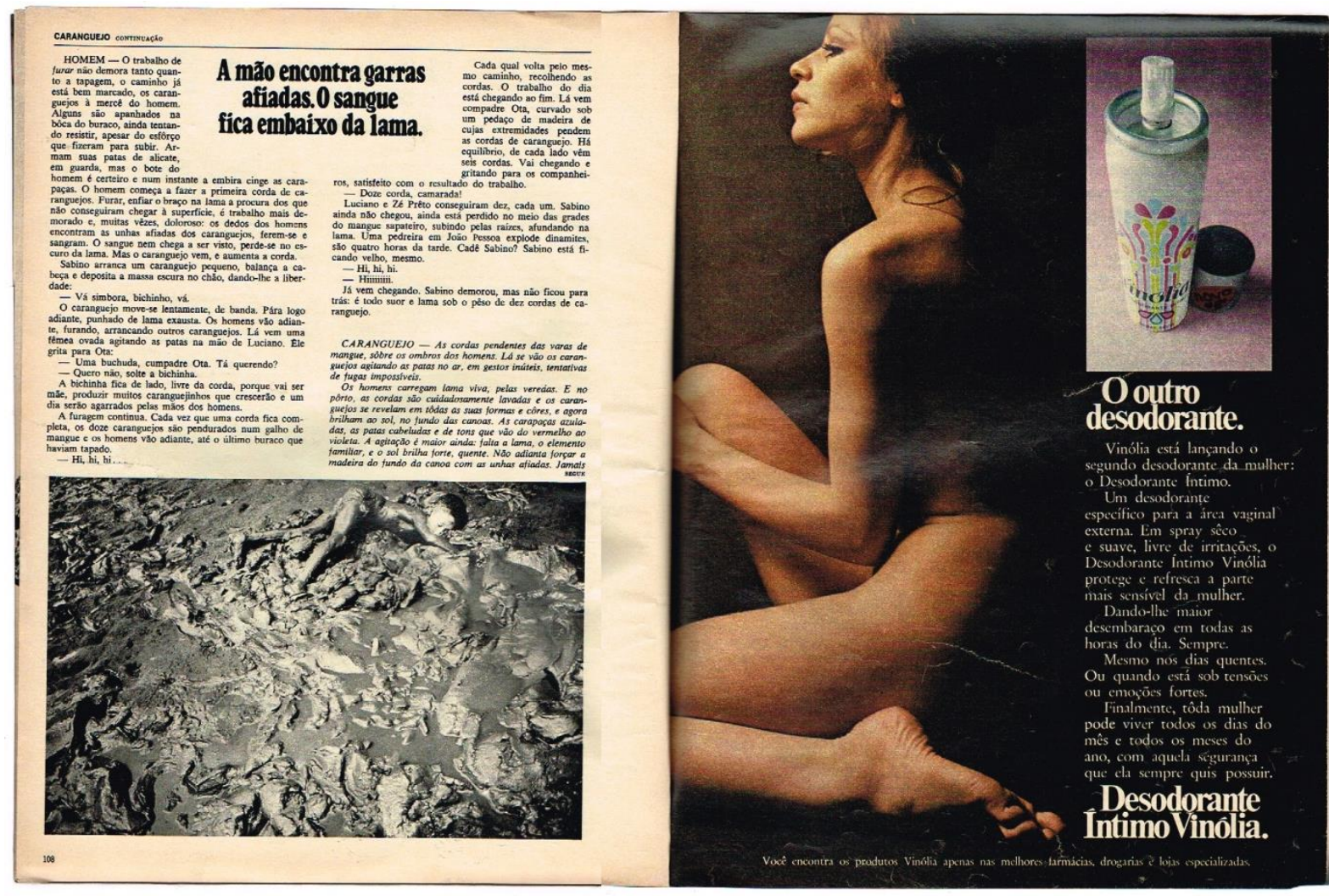

Fonte: Acervo do Grupo de Pesquisa Estudos Fotográficos (CNPq/UFCA)

Quanto ao caranguejo, em geral, perde a luta. Mas, em algumas situações bem específicas, ganha uma liberdade temporária. É o caso de um bem pequeno, apanhado por Sabino, que se despede dele com a seguinte frase: “- Vá simbora, bichinho, vá” (DANTAS, 1970, p. 108), mostrando que, apesar de inimigo, o pescador nutre algum tipo de sentimento positivo por aquele que lhe mantém vivo, lhe garante o sustento.

Uma fêmea prenha, ovada, também é libertada em função de sua condição. No entanto, está dará a luz a vários caranguejinhos, que mais tarde serão caçados pelo homem. Ela ganha a liberdade, mas uma liberdade condicionada, que no futuro significará todo aquele sacrifício e luta novamente. Nos termos do próprio autor, "a bichinha fica de lado, livre da corda, porque vai ser mãe, produzir muitos caranguejinhos que crescerão e um dia serão agarrados pelas mãos dos homens" (DANTAS, 1970, p. 108). 
Conforme vão completando as cordas com os doze caranguejos, os homens as vão pendurando em galhos de árvores. Ao final, quando furam o último dos buracos tapados, voltam recolhendo as cordas. Compadre Ota, o mais ágil, conseguiu doze cordas. Luciano e Zé Prêto, dez cada. Sabino é o último a chegar. Antes disso, os homens comentam que ele está ficando velho. No entanto, “já vem chegando. Sabino demorou, mas não ficou para trás: é todo suor e lama sob o peso de dez cordas de caranguejo" (DANTAS, 1970, p. 108). Apesar de idades diferentes, os homens mantêm-se em ritmos semelhantes de trabalho.

$\mathrm{Na}$ fotografia que compõe a página (Figura 17), observamos uma criança em meio à lama remexida. Pequenas poças de água se formam nos espaços por onde pés e mãos estiveram. O menino está com o braço parcialmente mergulhado na lama, em busca dos caranguejos. Para as crianças da região, a caça é uma brincadeira. No entanto, esta observação nos leva a uma consideração acerca da cultura local: a lida com o caranguejo está de tal forma arraigada na vida da comunidade que ela passa de brincadeira de criança a sustento da família, com naturalidade.

A criança se perde em meio à lama. A fotografia, em preto e branco, causa certo estranhamento num primeiro olhar. As curvas do corpo do menino se integram com o mangue. No entanto, é possível notar seu esforço a fim de conseguir mergulhar o braço em busca do caranguejo. Na inexperiência da infância, contorce-se em busca do mergulho.

A narrativa volta a ter no CARANGUEJO sua personagem principal. Após a captura, o mesmo é carregado com as patas para cima, totalmente indefeso e sem possibilidade de reação. Mas, ao menos, ainda seguem com parte daquilo que lhes é familiar: a lama. Em breve, após serem lavados no rio, o último dos elementos com os quais tinham uma relação de pertencimento se vai:

Os homens carregam lama viva, pelas veredas. E no porto, as cordas são cuidadosamente lavadas e os caranguejos se revelam em todas as suas formas e cores, e agora brilham ao sol, no fundo das canoas [...] A agitação é maior ainda: falta a lama, o elemento familiar, e o sol brilha forte, quente (DANTAS, 1970, p. 108).

O narrador reitera que o caranguejo foi arrancado de seu habitat, perdeu a luta para o homem, apesar de não desistir - continuar lutando para sair da canoa. A luz é o que os incomoda. Podemos ver esta informação destacada no olho da página (Figura 18). Não estão acostumados com aquilo. Os olhos permanecem fechados a maior parte do tempo. O narrador faz menção ao chiado, característico da fome do caranguejo, já citado no início da 
reportagem. Mais uma vez, também, no texto, o narrador se utiliza de pausas: "Fome. Espuma. Chiado" (DANTAS, 1970, p. 110).

Figura 18 - Povo Caranguejo, Revista Realidade, nº 48, mar. 1970, p. 110-111

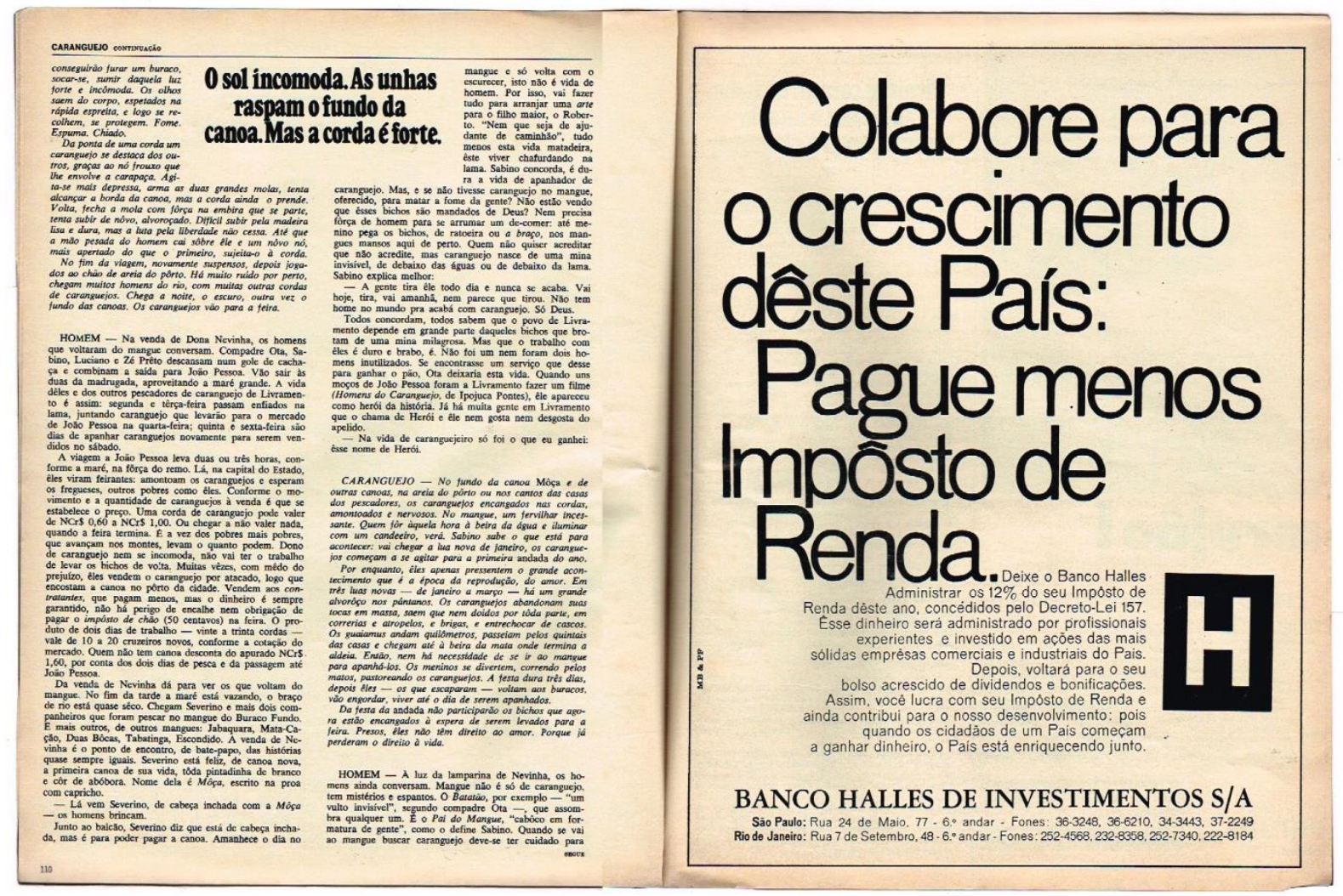

Fonte: Acervo do Grupo de Pesquisa Estudos Fotográficos (CNPq/UFCA)

No fim da viagem, novamente suspensos, depois jogados ao chão de areia do porto. Há muito ruído por perto, chegam muitos homens do rio, com muitas outras cordas de caranguejos. Chega a noite, o escuro, outra vez o fundo das canoas. Os caranguejos vão para a feira (DANTAS, 1970, p. 110).

No extrato acima, a narrativa é acelerada. Vemos que as personagens chegaram ao fim da primeira parte da viagem. Percebemos, também, que aquela ação da caça se repetia em muitos outros pontos da região. O texto dá pistas de que em breve eles chegarão a um ponto daquela cotidianidade sobre a qual já tivemos acesso a algumas informações ao longo do texto: a feita. Será o momento no qual o caranguejo dará lugar à farinha, ao feijão, aos mantimentos para a estrita sobrevivência da família. 


\subsection{O dia seguinte: o valor associado ao caranguejo e ao futuro}

Retornando a narrativa ao HOMEM, o vemos novamente na venda de Dona Nevinha, local no qual se reuniram pela manhã, antes de pegarem as canoas e partirem para o mangue. Ali combinam a viagem para João Pessoa, capital do estado, onde está localizada a melhor feira da região para vender o caranguejo e comprar o que for necessário. O narrador aproveita para explicar como é a rotina dos moradores daquela localidade:

A vida deles e dos outros pescadores de caranguejo de Livramento é assim: segunda e terça-feira passam enfiados na lama, juntando caranguejo que levarão para o mercado de João Pessoa na quarta-feira; quinta e sexta-feira são dias de apanhar caranguejos novamente para serem vendidos no sábado (DANTAS, 1970, p. 110).

Assim, a vida do homem está amarrada à do caranguejo de segunda-feira a sábado. Unidos na lama, no barco e na feira, em espaços distintos, mas sempre juntos. A cultura daquela comunidade, sua existência e subsistência dependem da lama e do animal. A luta com a natureza faz parte do cotidiano. Sem ela, não seria possível aos moradores ali viverem. Ou, teriam de estabelecer outra dinâmica de extrativismo, uma vez que aquela comunidade é estritamente rural.

Na capital, eles vão vender os caranguejos para pobres mais pobres do que eles. Viram feirantes. O preço da corda varia de acordo com o dia e com a oferta. Pode valer de NCr\$ 0,60 até $\mathrm{NCr} \$ 1,00$. Ou, no final da feira, passar a valer nada. É quando os mais pobres avançam e levam o que podem. Os pescadores/feirantes não se incomodam, para não terem o trabalho de levarem o bicho de volta para casa. Com medo do prejuízo, muitas vezes recorrem aos contratantes, homens que os esperam no porto e compram os caranguejos no atacado, a preços mais baixos, mas que os impedem de pagar o imposto de chão (valor para expor produtos no mercado) ou de ter o risco de não vender (DANTAS, 1970, p. 110).

O texto dá ênfase à situação de pobreza da localidade. Expressões como 'pobres como eles' ou 'pobres mais pobres que eles' são utilizadas para descrever as pessoas que interagem como o mercado e com os feirantes, bem como os próprios feirantes, já que estes são tomados como ponto de referência para a comparação.

De volta ao tempo presente da enunciação, à venda de Dona Nevinha, os homens comentam sobre Severino, um dos pescadores que acaba de comprar um barco, Moça. Aproveitando a fala do pescador sobre a dificuldade para pagar a canoa, o narrador trata de 
outras duas problemáticas locais: o futuro dos jovens e a dependência da comunidade em relação ao caranguejo:

- Lá vem Severino, de cabeça inchada com a Moça - os homens brincam. Junto ao balcão, Severino diz que está de cabeça inchada, mas é para poder pagar a canoa. Amanhece o dia no mangue e só volta com o escurecer, isto não é vida de homem. Por isso, vai fazer tudo para arranjar uma arte para o filho maior, o Roberto. "Nem que seja de ajudante de caminhão", tudo menos esta vida matadeira, este viver chafurdando na lama. Sabino concorda, é dura a vida de apanhador de caranguejo. Mas, e se não tivesse caranguejo no mangue, oferecido, para matar a fome da gente? (DANTAS, 1970 , p. 110, grifo do autor).

Nos termos do próprio Severino, Roberto não deverá seguir o caminho dos demais integrantes da comunidade. $\mathrm{O}$ homem identifica, naquela profissão, mais características negativas que positivas. As mesmas vêm sendo apresentadas ao longo do texto: dias afundados na lama em troca de pouco dinheiro, que mal dá para sustentar a família, cortes e dor no momento da furagem, a miséria na qual estão mergulhados. Aquela vida, em última análise, não seria uma 'vida', mas antes puro sofrimento.

Os homens concordam que a vida é dura, que o povo de Livramento depende do caranguejo, mas também acreditam que se existissem outras possibilidades, mudariam de profissão. Nas filmagens de Os Homens do Caranguejo ou A propósito de Livramento ${ }^{41}$, filme de Ipojuca Pontes realizadas no mesmo povoado em 1968, compadre Ota foi retratado como herói daquela história. Acabou herdando a alcunha. Pensando sobre o caso, declara: “Na vida de caranguejo só foi o que eu ganhei: esse nome de Herói” (DANTAS, 1970, p. 110).

Enquanto isso, os caranguejos esperam dentro das canoas, amontoados, nervosos. Tal estado advém de algo natural que está por chegar, a andada. Durante as três primeiras luas novas do ano - a viagem dos repórteres para a apuração da reportagem foi realizada em janeiro - há a busca pelo acasalamento, onde os caranguejos abandonam suas tocas e não é necessário ir aos pântanos para pegá-los. "A festa dura três dias, depois eles - os que escaparam - voltam aos buracos, vão engordar, viver até o dia de serem apanhados" (DANTAS, 1970, p. 110). Ou seja, o caranguejo está fadado a ser apanhado pelas mãos do homem.

\footnotetext{
${ }^{41}$ Mais informações no site da Cinemateca Brasileira. Disponível em: <http://cinemateca.gov.br/cgibin/wxis.exe/iah/?IsisScript=iah/iah.xis\&base=FILMOGRAFIA\&lang=P\&nextAction=search\&exprSearch=ID= 026699\&format $=$ detailed.pft>. Acesso em: 20 out. 2014.
} 
No fechamento deste fragmento da narrativa referente ao caranguejo, último que lhe cabe na reportagem, o narrador diz: "Da festa da andada não participarão os bichos que agora estão encangados à espera de serem levados para a feira. Presos, eles não têm direito ao amor. Porque já perderam o direito à vida" (DANTAS, 1970, p. 110). Sobre a última parcela, podemos traçar um paralelo entre o que está acontecendo com o caranguejo e o que acontecia com os presos políticos da ditadura militar. Muitos desapareceram e até hoje os familiares não encontraram seus corpos.

A última parte do texto, referente ao HOMEM, tem início com a lenda do Batatão. $\mathrm{O}$ Pai do Mangue, como também é conhecido, assombra os pescadores de caranguejo. Quando estão indo aos pântanos, os catadores não podem citar seu nome, sob pena de que todos os caranguejos sumam do mangue, como que por encanto. Nestas ocasiões, o chamam apenas por Compadre, no que o narrador nomina de uma 'intimidade medrosa' (DANTAS, 1970, p. 110-112).

"Ninguém vê a figura, mas a latumia dá para qualquer um ficar de cabelo arrepiado" (DANTAS, 1970, p. 112). O Batatão vigia os homens, não os deixa pronunciar seu nome e, caso seja chamado por algum desavisado ou corajoso, todos escutam seu barulho, assustam-se com sua bagunça. Aqui vislumbramos um paralelo com as ações da censura após a promulgação do AI5. Avisados por bilhetes, os jornalistas não poderiam tratar de determinados temas ou citar palavras previamente listadas. Caso o fizessem, a 'bagunça' seria percebida: edições cortadas ou apreendidas, jornalistas perseguidos ou presos.

Voltando aos homens no pântano, o perigo maior, na visão do narrador, estaria em cortar-se nas raízes do mangue e adoecer, ficando entrevado. A lama, a mesma que dá o alimento, a possibilidade de viver em meio à miséria, pode ser responsável pela morte do sujeito. Tamanha a quantidade de problemas que percebem em seu entorno, os moradores cultuam uma espécie de altar à modernidade, ao futuro. O mesmo está localizado na venda de Dona Nevinha. Quem lê os anúncios é a filha dela, uma das poucas pessoas alfabetizadas na região. No entanto, não consegue interpretar parte do que aparece nos jornais. Como é o caso da 'bola de cristal':

Na parede de tábua da venda, cheia de recortes de revistas mostrando artistas - Cauby Peixoto faz pose em robe de chambre -, há também um título de jornal que diz: O Recife é uma bola de cristal. Logo abaixo, outro recorte diz que 1970 é bom ano pra ganhar dinheiro. Severino, Ota, Sabino, Luciano, Zé Prêto e os outros ficarão por aqui, não têm mais jeito. Mas todos estão de 
acôrdo em que os moços se libertem da escravidão do caranguejo (DANTAS, 1970, p. 112).

O narrador explicita a opinião dos pescadores acerca daquela condição de vida: não a desejam para seus filhos. Vivem-na porque não existe outra opção. Talvez não a tenham deixado na juventude justamente por não haver, à época, nas cidades de Recife ou de João Pessoa tal espectro de esperança para um futuro mais digno, menos miserável. Longe da lama.

Figura 19 - Povo Caranguejo, Revista Realidade, nº 48, mar. 1970, p. 112-113

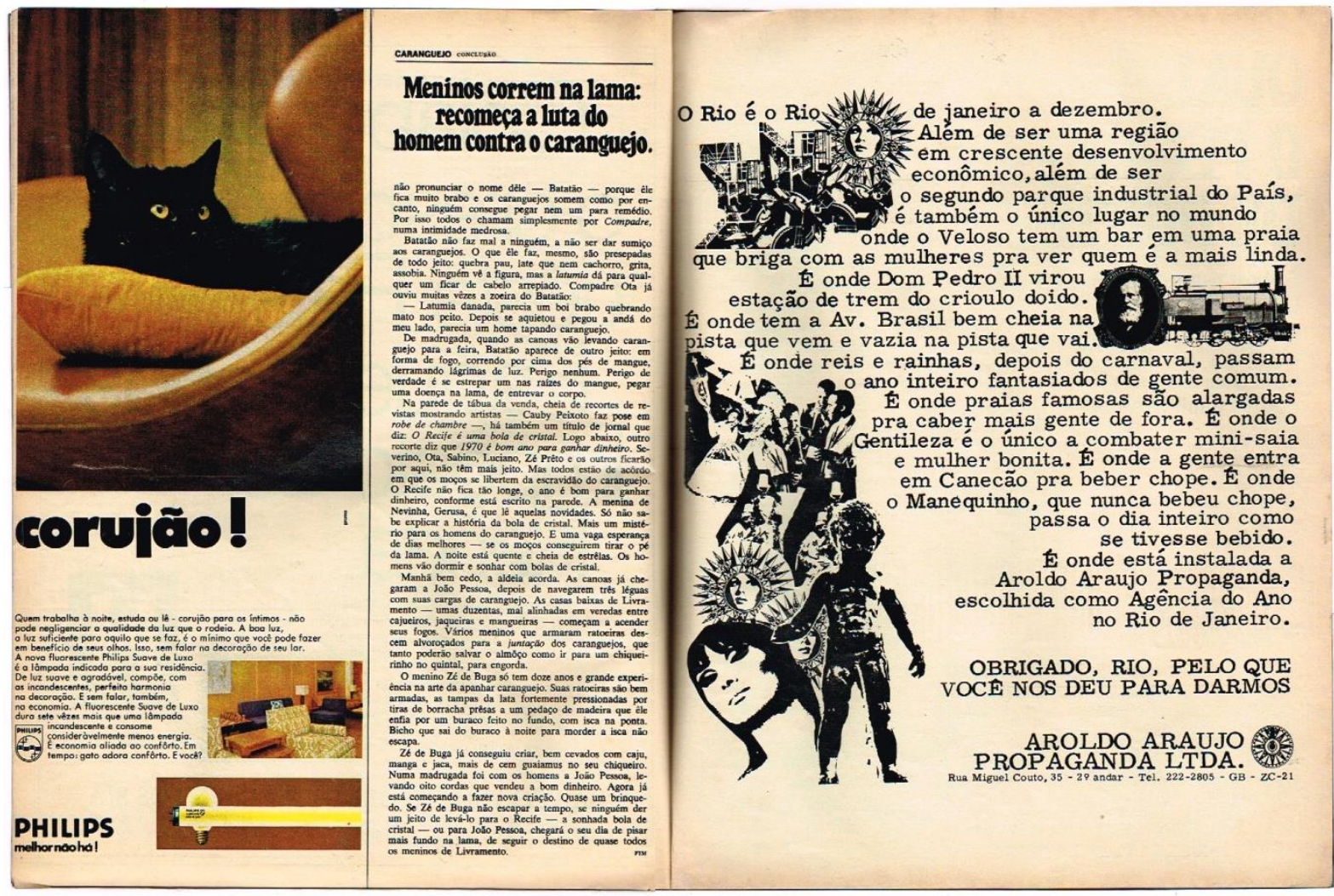

Fonte: Acervo do Grupo de Pesquisa Estudos Fotográficos (CNPq/UFCA)

Como nos prepara o olho da página (Figura 19), os últimos três parágrafos da reportagem tratam de crianças. Para tanto, utiliza como exemplo o caso de Zé de Buga. "Meninos correm na lama: recomeça a luta do homem contra o caranguejo" (DANTAS, 1970, p. 112). O texto indica que logo na infância tem início a luta. Os meninos montam as ratoeiras e no dia seguinte, bem cedo, correm para a juntação. Os caranguejos apreendidos poderão ser utilizados para o almoço ou serem criados em chiqueirinhos, alimentados com frutas recolhidas no quintal de casa. 
Zé de Buga tem doze anos, mas já criou mais de cem caranguejos, alimentando-os com caju, manga e jaca. Foi juntamente com os homens, vendê-los em João Pessoa. Para ele, caçar, criar e vender o animal é praticamente um brinquedo. Algo naturalizado, que faz por ver os outros moradores da vila fazendo. Reproduz a cultura local, admitindo-a enquanto sua. No entanto, o encerramento do texto transparece um clima de prenúncio acerca do futuro daqueles meninos:

Agora já está começando a fazer nova criação. Quase um brinquedo. Se Zé de Buga não escapa a tempo, se ninguém der um jeito de levá-lo para o Recife - a sonhada bola de cristal - ou para João Pessoa, chegará o seu dia de pisar mais fundo na lama, de seguir o destino de quase todos os meninos de Livramento (DANTAS, 1970, p. 112).

No Quadro 2, elencamos os termos destacados graficamente ao longo do texto. São palavras próprias daquela região ou, em sua maioria, características daquele labor. Como podemos observar, todos se encontram nas parcelas referentes ao HOMEM. Apenas uma, a 'andada', também pode ser lida nos textos referentes ao CARANGUEJO. Associamos tal observação ao fato de o homem produzir ações, interagir com o ambiente na intenção de dominá-lo, como inimigo do caranguejo. Assim, o mesmo teve a necessidade de criar termos acerca das etapas de caça, para explicar o ambiente (mitos) ou para estabelecer as interrelações que o envolvem em torno da lida com o caranguejo. Vejamos quais foram os termos e seus significados:

Quadro 2 - Termos em destaque em Povo Caranguejo, por ordem de entrada no texto

\begin{tabular}{|c|c|c|}
\hline Termo & Personagem & Descrição \\
\hline Ratoeira & Homem & $\begin{array}{l}\text { Brinquedo infantil improvisado para caçar } \\
\text { caranguejo, feito com lata de óleo vazia. }\end{array}$ \\
\hline Boi de fogo & Homem & $\begin{array}{l}\text { Lata onde são queimados pedaços de madeira com a } \\
\text { finalidade de afastar mosquitos e acender cachimbos. }\end{array}$ \\
\hline Andada & $\begin{array}{l}\text { Homem / } \\
\text { Caranguejo }\end{array}$ & $\begin{array}{l}\text { Momento de acasalamento, durante o qual os } \\
\text { caranguejos saem de suas tocas. }\end{array}$ \\
\hline Cordas & Homem & 12 caranguejos, amarrados por embirras. \\
\hline Sapateiro & Homem & Tipo de mangue. \\
\hline Grades & Homem & $\begin{array}{l}\text { Emaranhado de raízes do mangue sapateiro, onde } \\
\text { está a maior quantidade de caranguejos e também os } \\
\text { de maior tamanho. }\end{array}$ \\
\hline Aratus & Homem & $\begin{array}{l}\text { Espécie pequena de caranguejo, sem interesse } \\
\text { comercial. }\end{array}$ \\
\hline Tapagem & Homem & Primeira etapa do trabalho. Consiste em obstruir o \\
\hline
\end{tabular}




\begin{tabular}{|l|l|l|}
\hline & & caminho feito pelo caranguejo dentro da lama. \\
\hline Furagem & Homem & $\begin{array}{l}\text { Retirada do caranguejo do buraco anteriormente } \\
\text { 'tapado'. }\end{array}$ \\
\hline Furar & Homem & Ato de praticar a furagem. \\
\hline Contratantes & Homem & $\begin{array}{l}\text { Compradores que já esperam os pescadores na } \\
\text { entrada do porto e compram o caranguejo por } \\
\text { atacado, pagando um valor inferior. }\end{array}$ \\
\hline Imposto de chão & Homem & $\begin{array}{l}\text { Importância no valor de 50 centavos paga na feira a } \\
\text { fim de utilizar aquele espaço. }\end{array}$ \\
\hline Arte & Homem & Trabalho, ocupação. \\
\hline A braço & Homem & $\begin{array}{l}\text { Forma de pegar o caranguejo com as próprias mãos, } \\
\text { por crianças, durante a andada. }\end{array}$ \\
\hline $\begin{array}{l}\text { Batatão / Pai do } \\
\text { Mangue }\end{array}$ & Homem & $\begin{array}{l}\text { Mito do mangue. Se contrariado, faz com que todos } \\
\text { os caranguejos desapareçam, por encanto. }\end{array}$ \\
\hline Compadre & Homem & $\begin{array}{l}\text { A forma como os pescadores se referem ao Batatão } \\
\text { quando estão no mangue, a fim de que os caranguejos } \\
\text { não desapareçam, numa forma de intimidade que } \\
\text { remete ao medo. }\end{array}$ \\
\hline Latumia & Homem & Lamentação, barulho. \\
\hline Robe de chambre & Homem & Tipo de vestimenta, não comum na região. \\
\hline Juntação & $\begin{array}{l}\text { Ato de pegar os caranguejos que ficaram presos nas } \\
\text { ratoeiras armadas pelas crianças. }\end{array}$ \\
\hline
\end{tabular}

Fonte: os autores.

Ao longo do percurso de leitura da reportagem, elencamos como palavras-chave para a redação da mesma os termos lama e miséria. Neste contexto, tais palavras transmutam-se em diversos sentidos. A lama, além do objeto em si, água e terra que compõe o mangue, também pode ser entendida como a própria miséria na qual o homem afunda, para a qual é empurrado pela condição na qual vive. O ambiente, e por conseguinte o Estado, não lhe dando outras condições de subsistência, implicam-no em uma condição cultural de lida com o caranguejo.

Ao tratar das condições de vida e trabalho daquela comunidade, os narradores traçam um retrato de uma pequena aldeia, distante e esquecida, historicamente predestinada à miséria e à humilhação diária. Em meio ao texto, os pescadores clamam por auxílio, mas que este venha às crianças, pois eles já estão acostumados àquilo e não veem a possibilidade de mudança imediata. Enquanto o Brasil cresce, aqueles brasileiros buscam na lama a sobrevivência. 


\section{NARRATIVA IV: QUEM É O HOMEM NO FUNDO DO POÇO?}

A partir da década de 1930, o estado de São Paulo foi um dos principais palcos de destino das migrações internas do país. De acordo com Baeninger (2012), até os anos de 1970 houve um deslocamento intersetorial da mão-de-obra, havendo transferência de trabalhadores das áreas rural para a industrial, o que contribuiu para o processo de industrialização nacional. Estima-se que, entre os anos de 1926 e 1960, São Paulo tenha recebido cerca de 2,5 milhões de migrantes internos (BAENINGER, 2012).

Com o crescimento do número de fábricas, houve também o desenvolvimento do movimento operário. Os movimentos dos grupos operários ligaram-se, diretamente, à situação política do país, tendo impacto, por exemplo, na promulgação do Ato Institucional $\mathrm{N}^{\mathrm{o}} 5$ :

[...] desde o golpe de 1964, não havia ocorrência de greves no Brasil: quatro anos sem paralisações representavam uma vitória importante para a ordem estabelecida, não apenas no sistema político, mas também para o sistema produtivo e social. Assim, a eclosão das greves de Contagem (MG), de 16 a 18 de fevereiro de 1968, e da Cobrasma, em Osasco (SP), de 16 a 24 de abril de 1968 , teve forte impacto no aumento das muitas tensões que levaram ao AI-5 (NORONHA; ERVOLINO, 2014, p. 94).

Tendo em vista a asfixia dos movimentos, por parte do regime, a próxima greve de operários só viria a acontecer em 1978. No entanto, a situação percebida pelo quadro daquele ano aponta para a insatisfação que os operários enfrentaram durante os dez anos que não conseguiram se organizar: foram registradas 111 greves no ano de 1978 e mais 187 paralizações no ano de 1979 (NORONHA; ERVOLINO, 2014).

A redação de Realidade dispunha de dados, em 1970, que apontavam para a miséria na qual viviam os trabalhadores que recebiam um salário mínimo no país, dando-se especial atenção para o quadro paulista. Vislumbraram neles a possibilidade de lançar luz sobre a verdade por trás da propaganda governista. Nos termos de Audálio Dantas, responsável pela 
pauta, "Esses números desmentiam os militares do Golpe de 1964, que apregoavam um 'Brasil Grande'. Isso dava mais importância à reportagem, mesmo que, para driblar a censura, não se atribuísse culpa ao governo. Bastava mostra a verdade dos números” (DANTAS, 2012, p. 178).

Desvelando a intenção do grupo que fazia parte de Realidade, Audálio Dantas admite que, ao proporem a pauta que deu origem à reportagem sobre a qual nos debruçamos neste momento, aqueles jornalistas acreditavam que estariam contribuindo para combater a ditadura militar, mesmo que de uma forma, em partes, ingênua (DANTAS, 2012, p. 178).

\subsection{O diálogo entre páginas: a apresentação da personagem}

É em meio a este contexto que é lançado, em janeiro de 1971, o número 58 de Realidade, contendo a reportagem Quem é o homem no fundo do poço ${ }^{42}$. No sumário, sob a classificação editorial de 'Problema', há a chamada para um trabalho cujo objetivo é mostrar como vive uma família com a renda de um salário mínimo. Na primeira página dupla destinada ao texto (Figura 20), podemos observar uma fotografia emblemática e curiosa: um homem, apoiando-se nas paredes de um poço, olha fixamente para o repórter. Na margem direita, um pequeno trecho indica a autoria da reportagem: texto de Audálio Dantas e fotografias de Jean Solari.

Sobre a fotografia, no topo da página dupla, um questionamento que dialoga diretamente com o texto visual: 'Quem é o homem no fundo do poço?'. Há um diálogo explícito entre o título e a fotografia. O chamado 'fundo do poço', apesar de referir-se diretamente à imagem, permite que o leitor faça uma relação com a famosa expressão, a qual se refere a um problema irresolvível, a uma situação que deixa o sujeito em estado de miséria, especialmente ligado com questões profissionais e financeiras.

Ao observarmos a imagem, percebe-se um destaque especial dado ao olhar do homem, um sujeito que, até aqui, não possui nome ou profissão. Uma personagem que representa todos aqueles que estão no fundo do poço, que estão na miséria. Mesmo se tratando de um período de forte crescimento econômico, a revista dá indícios de que tal situação de desespero e falta de possibilidades pode, e deve, estar acontecendo em alguma parte do país.

\footnotetext{
${ }^{42}$ Ao tratar da reportagem, em livros de memórias, Audálio Dantas a intitula como Joaquim Salário Mínimo. Porém, destacamos aqui, este é o título da segunda página dupla (Figura 2), motivo pelo qual optamos por chamar a reportagem de Quem é o homem no fundo do poço?, título da primeira página dupla (Figura 1).
} 


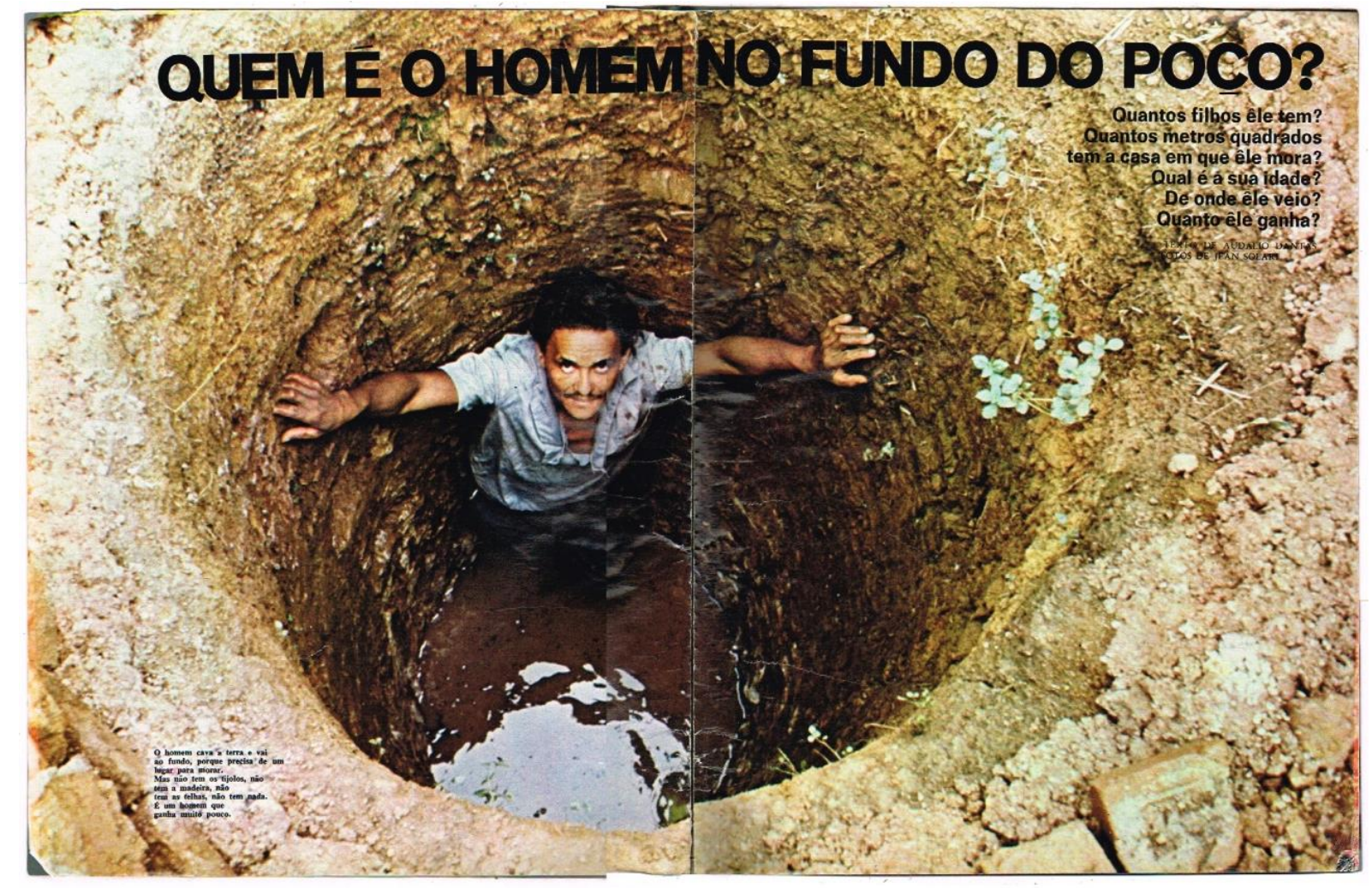

Fonte: Acervo do Grupo de Pesquisa Estudos Fotográficos (CNPq/UFCA)

Com as mãos sujas, a camisa desabotoada e calças pretas, o homem esboça um sorriso, apoiando-se no poço que o acolhe. Não parece haver possibilidade para saída, ao mesmo tempo em que ele não esboça uma reação de desespero. No fundo do poço há água, o que poderíamos classificar como a imagem da esperança. $\mathrm{O}$ poço cavado visa à possibilidade de encontrar água. Aquele homem tem de ter a esperança de encontrar o líquido, para ali estar. A água começa a brotar, há esperança para o homem encerrado em meio ao barro vermelho.

Abaixo da palavra 'poço', no título, chamando a atenção para aquela parcela da página, cinco perguntas lançam questionamentos acerca do homem retratado:

\footnotetext{
Quantos filhos ele tem?

Quantos metros quadrados tem a casa em que ele mora?

Qual é a sua idade?

De onde ele veio?

Quanto ele ganha? (DANTAS, 1971, p. 09).
}

A sequência de questionamentos não é encadeada, não segue a ordem esperada de uma conversa que vise a conhecer alguém. Não há indicações acerca do nome do sujeito. Há um 
destaque especial dado às dimensões do local onde ela habita: tanto do ponto de vista físico quanto material. Além disso, já se pode perceber que o homem não pertence àquele local. É estrangeiro ao ambiente.

Na parte inferior esquerda, uma pequena legenda da fotografia nos dá as primeiras informações sobre a personagem em questão: "O homem cava a terra e vai ao fundo, porque precisa de um lugar para morar. Mas não tem os tijolos, não tem a madeira, não tem as telhas, não tem nada. É um homem que ganha muito pouco" (DANTAS, 1971, p. 08).

O homem em questão não possui um nome. Tem um rosto, para o qual podemos olhar, mas vemos nele o reflexo de toda uma parcela da população brasileira. O sujeito que afunda no barro não o faz por querer, mas por necessidade. Ao destacar que ele não tem o material para construir a casa, o narrador não trata apenas da parte física necessária à construção: fala também de passado, de futuro, de relações afetivas, de uma vida justa e confortável. Ao não ser possuidor de nada, o homem está mergulhado em incertezas.

Neste contexto, a terra pode ser tida como o país, a relação de pertencimento que o sujeito tem para com as relações de brasilidade. Ele cava a terra, indo mais fundo. Mergulha nos problemas que o envolvem por conta da necessidade que tem de ter onde morar. Essa é a justificativa para o homem cavar a terra, buscar uma forma de sobreviver, apesar dos problemas.

Ao virar a página, deparamo-nos com mais uma fotografia em página dupla (Figura 21). Desta vez, o homem no fundo do poço ganha um nome: Joaquim, um sujeito de 36 anos. $\mathrm{Na}$ fotografia, uma família inteira, composta por sete pessoas, divide um pequeno espaço. Em contrataste com a imagem anterior, sendo aquela iluminada, esta aponta para uma situação noturna: a hora de dormir. Repetindo o padrão anterior, ambas as fotografias foram tomadas de um ângulo superior aos retratados.

Todas as personagens da fotografia estão acordadas, com os olhos abertos. Os dois meninos, localizados na parte inferior direita da página, miram diretamente o fotógrafo, ao passo que os demais fixam o olhar em diferentes partes do espaço. Encarcerados, enjaulados, as sete personagens são nomeadas em legendas sobrepostas à fotografia. Assim, percebemos que Joaquim e Ana (33 anos) são os pais, enquanto Clemente (11 anos), Donizeti (nove anos), Donizita (oito anos), Laurinda (seis anos) e Aparecida (um ano) são os filhos. Destacamos que este recurso de sobreposição para a identificação das personagens foge aos padrões anteriores da revista, do ponto de vista da diagramação. 
Figura 21: Quem é o homem no fundo do poço?, Revista Realidade, $\mathrm{n}^{\circ}$ 58, jan. 1971, p. 10-11

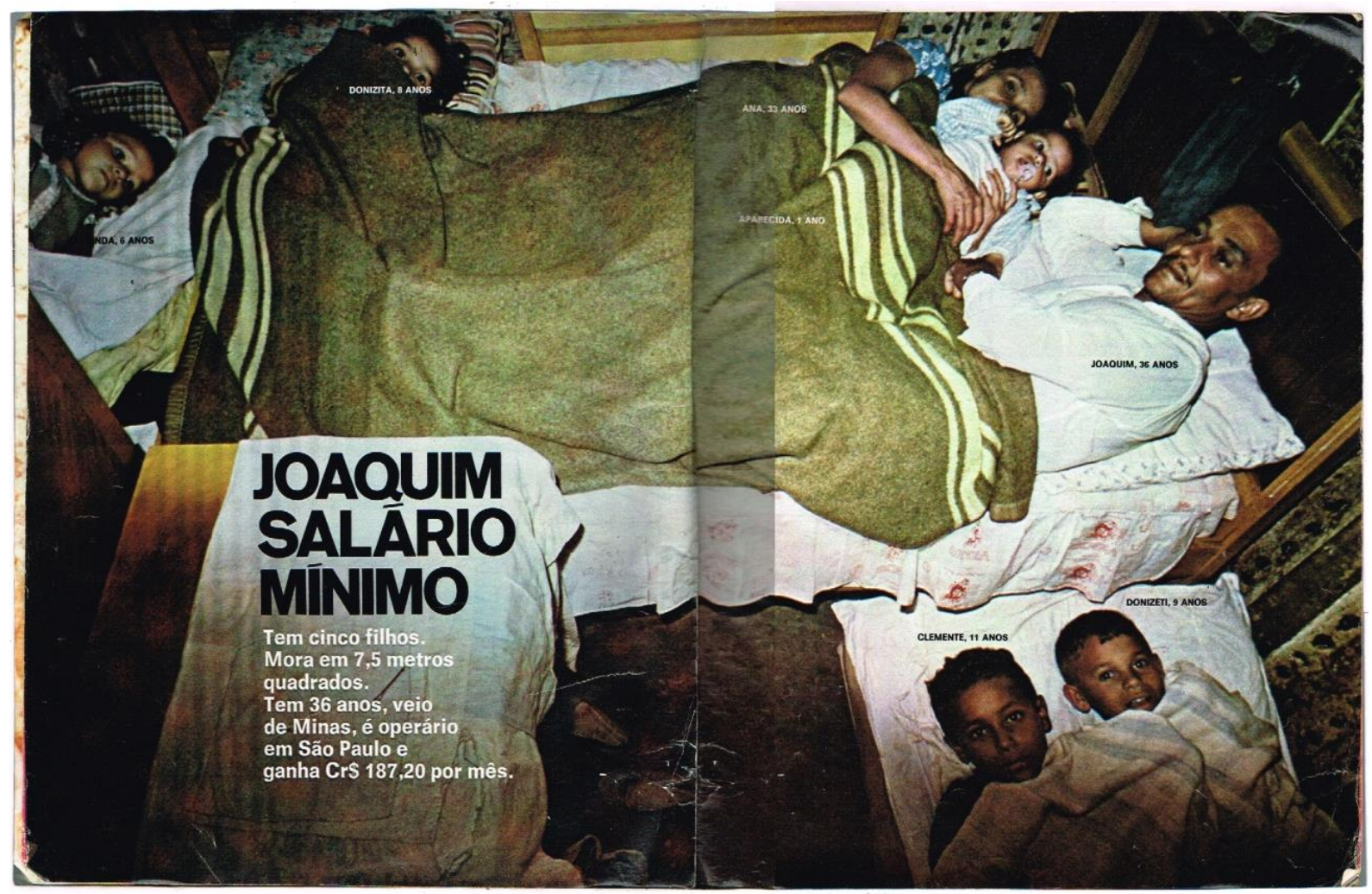

Fonte: Acervo do Grupo de Pesquisa Estudos Fotográficos (CNPq/UFCA)

Nos limites da imagem podemos perceber as ripas, paredes de madeira da casa. Alguns poucos móveis completam a composição. As personagens dividem o espaço, os lençóis, o ar. O espaço é pequeno. O que vemos na fotografia não é apenas um cômodo da casa, mas sim todo o espaço dividido pela família. Podemos ter a dimensão da situação ao lermos a introdução da reportagem, impressa na página par: “Tem cinco fillhos. Mora em 7,5 metros quadrados. Tem 36 anos, veio de Minas, é operário em São Paulo e ganha Cr\$187,20 por mês" (DANTAS, 1971, p. 10). Este pequeno parágrafo é composto, respeitando a ordem, pelas repostas às perguntas da primeira página dupla.

Esta é a vida de 'Joaquim Salário Mínimo', personagem da reportagem que ora analisamos. 'Salário Mínimo', portanto, surge como o sobrenome da personagem, uma característica definidora deste sujeito. Os sobrenomes estão ligados ao local de origem, ao grau de parentesco, às alcunhas ou à ocupação dos sujeitos. No caso de Joaquim, a condição utilizada para sobrevivência assume um caráter definidor de sua relação com a vida em sociedade. As atitudes, o cotidiano do sujeito e de sua família, são definidas pela quantia recebida ao mês. 
Além da relação tratada anteriormente, podemos fazer uma associação direta entre os dois títulos de página, conforme a Figura 22:

Figura 22: Quadro relacional entre títulos de página

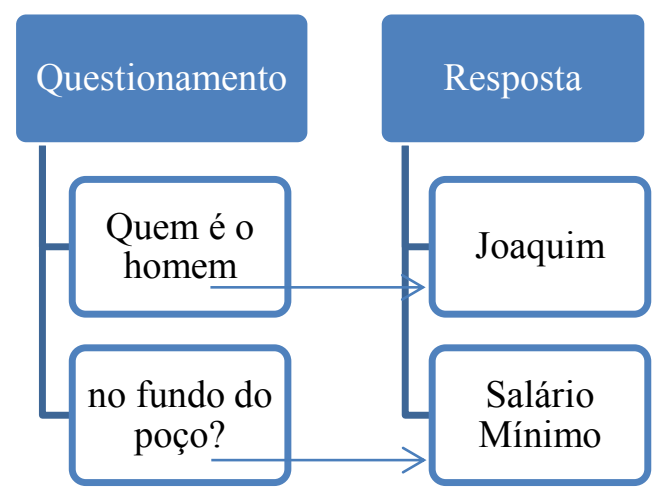

Fonte: os autores.

\subsection{Pode entrar: o narrador apresenta o ambiente}

Numa leitura relacional, o salário mínimo brasileiro daquele momento histórico seria equivalente ao 'fundo do poço' no qual o homem, agora nomeado Joaquim, vive. A informação é reforçada pelo título de página da terceira página dupla (Figura 23): "Dinheiro, pouco. Comida, pouca. Alegria, nenhuma” (DANTAS, 1971, p. 12-13).

As quatro fotografias que compõem a página descrevem detalhes do ambiente no qual a família vive. Na maior delas, impressa na página par, podemos observar o ambiente esterno ao quarto no qual vive a família em questão. O espaço está tomado por objetos: bacias, pedaços de madeira, tecidos e embalagens. No primeiro plano uma criança, que parece ser uma menina, mexe em uma bacia de água. Seus cabelos estão molhados. A legenda da fotografia destaca ser aquele um local que tem as mais diversas utilidades, indo desde banheiro até parque infantil para as crianças que fazem parte das três famílias que ali residem.

$\mathrm{Na}$ página impar podem ser observadas mais três fotografias. Na primeira delas, um dos desejos de consumo da família: carne. A mulher, no primeiro plano, tem as feições envelhecidas. No segundo plano, a carne, desfocada, parece distante, parte de um sonho. A legenda traça uma comparação entre o valor da carne e o valor atribuído ao salário de Joaquim. Um quilograma, de qualidade inferior, equivale a mais da metade do que Joaquim ganha por dia. A solução é racionar: um pedacinho, de 250 gramas, uma ou duas vezes por mês. Há uma festa em casa, com a chegada da carne. O alimento, portanto, assume a aura 
daquilo que é impossível, uma utopia, corroborado pela imagem. Não se pode comer carne todos os dias, não se tem condição financeira suficiente para tal.

Figura 23: Quem é o homem no fundo do poço?, Revista Realidade, $\mathrm{n}^{\circ}$ 58, jan. 1971, p. 12-13

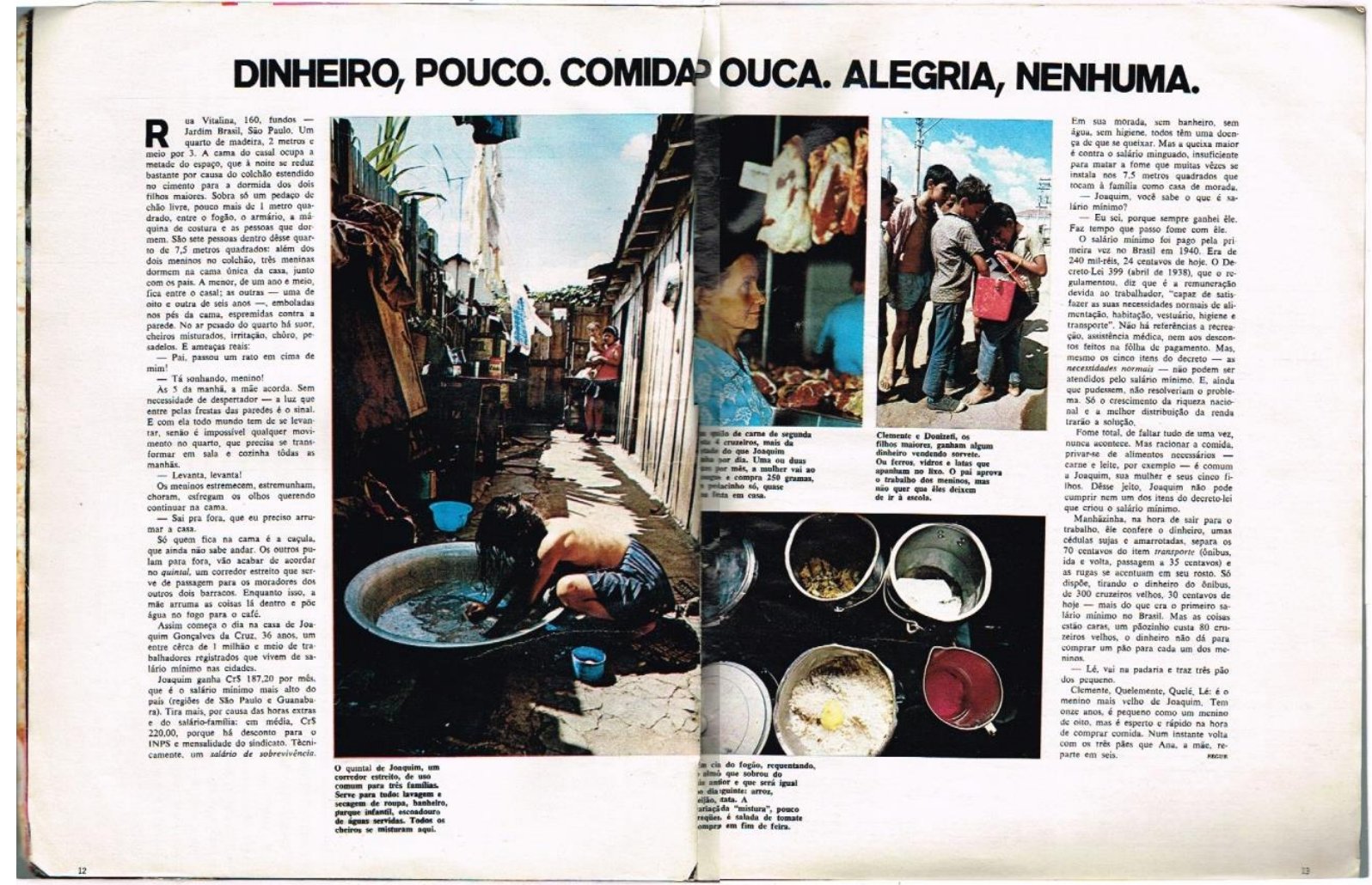

Fonte: Acervo do Grupo de Pesquisa Estudos Fotográficos (CNPq/UFCA)

A segunda imagem é composta por um grupo de crianças, entretidas em volta de um isopor. Pode-se distinguir ao menos seis meninos em torno do objeto. Dois deles são os filhos mais velhos de Joaquim. Os meninos ajudam em casa como podem, apesar da idade. Eles vendem sorvete na região. Esta é a cena retratada. Mas também vendem coisas que encontram no lixo. O pai aprova, posto que seja uma opção a mais para fugirem da fome. Mas não aceita que tais ações prejudiquem os estudos. O mais importante, portanto, é buscar uma forma de, honestamente, sair da condição de pobreza em que vivem.

Por fim, o leitor pode observar, antes de mergulhar no texto, uma fotografia tomada de um ângulo superior aos objetos, na qual se veem quatro panelas destampadas. Aquele é o almoço corriqueiro para as personagens: arroz, feijão e batata. No entanto, a informação mais incômoda advém do final da legenda: “A variação de 'mistura', pouco frequente, é salada de tomate comprado em fim de feira" (DANTAS, 1971, p. 13). A família vive dos restos, daquilo 
que os outros não querem. É preciso fazer isso, posto que o dinheiro disponível não conceda que se realize escolhas, não permite viver como se gostaria. Não possibilita uma alimentação saudável, um lugar com plenas condições de higiene.

O texto da reportagem tem início com a transcrição de um endereço. Posteriormente, passa à descrição física do imóvel ali encontrado. Por fim, entra no imóvel, descrevendo os detalhes do espaço, durante o dia e à noite:

Rua Vitalina, 160, fundos - Jardim Brasil, São Paulo. Um quarto de madeira, 2 metros e meio por 3 . A cama do casal ocupa a metade do espaço, que à noite se reduz bastante por causa do colchão estendido no cimento para a dormida dos filhos maiores. Sobra só um pedaço de chão livre, pouco mais de 1 metro quadrado, entre o fogão, o armário, a máquina de costura e as pessoas que dormem (DANTAS, 1971, p. 12).

Segundo a descrição encontrada no texto, as personagens e os objetos assumem o mesmo status de elementos que compõem o ambiente. Eles coabitam e possuem um lugar definido no espaço. Cada um assume uma determinada parcela daqueles 7,5 metros quadrados. Acerca dos elementos encontrados na casa, podemos perceber que há apenas o indispensável. Não há geladeira, por exemplo. Não haveria espaço para uma. $\mathrm{O}$ um metro quadrado que resta é um espaço para a respiração do ambiente.

O narrador continua a mergulhar o leitor no cenário, no clima, do pequeno quarto. Da descrição física, passa à descrição imaterial composta pelos cheiros que inundam o ambiente: "No ar pesado do quarto há suor, cheiros misturados, irritação, choro, pesadelos" (DANTAS, 1971, p. 12). Além de não haver espaço físico, também não o há para os bons sentimentos. Todos os elementos elencados têm uma conotação negativa. O suor, mesmo remetendo ao trabalho, refere-se também ao baixo salário que dele advém, além dos problemas de higiene que ali existem.

A irritação, o choro e os pesadelos são elementos que contribuem para pesar o ar. $\mathrm{O}$ ambiente não é convidativo nem acolhedor. Ele inspira desespero e parece descrever o inferno, elemento do catolicismo. Os pesadelos, no entanto, são imateriais e contrastam com os problemas provenientes das condições de saneamento: os ratos passeiam por cima das crianças. Numa tentativa de fuga da realidade, e mesmo de preservar os filhos dos problemas que ali existem, o homem fecha os olhos aos problemas sanitários do local. O perigo, assim, assume a forma de sonho: “- Pai, passou um rato em cima de mim! - Tá sonhando, menino!" (DANTAS, 1971, p. 12). 
O ambiente do quarto não é convidativo, bem como expulsa os moradores dali. Há frestas nas paredes de madeira, o que faz com que a mãe acorde junto com o nascer do sol e, mais que isso, retire todas as pessoas de dentro do espaço: é preciso que todos estejam levantados para que as atividades do dia tenham início. Há uma transmutação do ambiente, juntamente com o nascer do sol. O quarto para sete pessoas se transforma em sala e cozinha.

A reportagem repete, em mais de uma oportunidade, um encadeamento de informação de caráter negativo relacionado com o detalhamento dado a uma determinada informação. Após serem acordados pela mãe, os filhos reclamam da situação cotidiana de suas vidas: "Os meninos estremecem, estremunham, choram, esfregam os olhos querendo continuar na cama" (DANTAS, 1971, p. 12).

O luxo de dormir não cabe a nenhuma das personagens desta reportagem. Tão logo nasça o sol, todos são obrigados a sair de casa, a deixar o pequeno conforto do colchão. A caçula, no entanto, tem de ficar na cama, posto que ainda não saiba andar. Ainda assim, ela não estará confortável em tal situação, uma vez que o pequeno quarto se irá converter em ambiente de trabalho doméstico. Todas as ações das personagens se desenvolverão no pequeno espaço.

Ao saírem de casa, as crianças passam ao quintal. O termo está destacado em itálico, no texto. $\mathrm{O}$ destaque nos indica que o autor não encontrou outra palavra que conseguisse definir a situação do espaço ali encontrado, ao mesmo tempo em que aponta para um tom de ironia: aquele, na verdade, é “[...] um corredor estreito que serve de passagem para os moradores dos outros dois barracos" (DANTAS, 1971, p. 12). São, assim, ao menos três famílias vivendo em condições semelhantes, driblando os mesmos problemas, sofrendo as mesmas penúrias.

Após a apresentação do ambiente, das condições físicas e sanitárias do local, o narrador apresenta a personagem principal da narrativa: "Assim começa o dia na casa de Joaquim Gonçalves da Cruz, 36 anos, um entre cerca de 1 milhão e meio de trabalhadores registrados que vivem de salário mínimo nas cidades" (DANTAS, 1971, p. 12). Neste momento, o Joaquim do título da reportagem ganha um sobrenome, passa a ser uma personagem específica. Contudo, ele também faz parte de uma multidão: é um caso específico, que se repete, sem grandes modificações, em outros quartos da cidade. Joaquim é o reflexo da condição em que vive uma parcela dos brasileiros.

Apesar de a cidade de São Paulo possuir o mais alto salário mínimo do país, naquela ocasião, o valor ainda não se faz suficiente para atender às necessidades de uma família. $\mathrm{O}$ 
texto aponta para as alternativas destes trabalhadores: precisam fazer hora-extra e recebem ainda o salário-família: mas há descontos do Instituto Nacional de Previdência Social $(\text { INPS })^{43}$ e do sindicato.

Após demonstrar a situação orçamentária de Joaquim, o narrador define aquele como sendo um 'salário de sobrevivência'. Mais uma vez utilizando-se do artifício do destaque em itálico, o narrador ironiza a situação. Recebendo tão pouco, tendo famílias tão numerosas, o trabalhador apenas tem o direito de sobreviver (no sentido de continuar a existir, apesar de passar por uma situação grave), não de viver (o qual estaria relacionado com o ato de gozar a vida).

A remuneração dos operários paulistas, mesmo em um período de forte crescimento econômico, não atende às necessidades básicas. Desta forma, mesmo os brasileiros que se encontram no centro das atividades econômicas do país estão submetidos às mais diversas problemáticas, como veremos ao longo desta narrativa. As condições sanitárias, naturalmente, refletem-se na condição de vida dos sujeitos:

Em sua morada, sem banheiro, sem água, sem higiene, todos têm uma doença de que se queixar. Mas a queixa maior é contra o salário minguado, insuficiente para matar a fome que muitas vezes se instala nos 7,5 metros quadrados que tocam à família como casa de morada (DANTAS, 1971, p. $13)$.

As personagens vivem imersas em problemas, de forma que se faz difícil decidir qual das problemáticas tem maior importância em suas vidas. Têm condições de queixar-se de tudo. O salário de sobrevivência não abrange às condições mínimas para tal: a fome faz parte da caracterização do ambiente, instalando-se como um sujeito palpável, entre as paredes do quarto. Nestes termos, a fome é um dos elementos mais importantes da narrativa, da vida desta família, da condição de vida daqueles que são operários no estado. Para além do 'estado de fome', que seria passageiro, o trecho acima faz referência a uma situação constante, uma vez que ela ali se instala muitas vezes.

\subsection{O papel do narrador: entre dados e questionamentos}

Ao longo da reportagem são feitos alguns questionamento, sem que haja, necessariamente, uma personagem responsável por eles. No entanto, podemos entender que

\footnotetext{
${ }^{43}$ Órgão criado em 1 de janeiro de 1967.
} 
sejam pequenas intervenções feitas pelo repórter. Ele aflora do texto, como personagem, fazendo perguntas curtas e objetivas, conduzindo a narrativa, quando julga necessário. Vejamos o primeiro caso onde se dá a interação do repórter com a construção da narrativa. “Joaquim, você sabe o que é salário mínimo? - Eu sei, porque sempre ganhei ele. Faz tempo que passo fome com ele" (DANTAS, 1971, p. 13).

Fala-se, ao longo do texto, no salário mínimo da época. Ele, inclusive, pode ser lido como um elemento definidor da personagem principal da narrativa. Joaquim tem um conhecimento empírico acerca do valor, bem como vivencia as consequências de tal remuneração: passa fome. Aqui podemos perceber, por meio da frase de efeito anterior, o peso dado, na narrativa, à situação de fome.

Em consideração à afirmação de Joaquim, o narrador traz a definição legal de salário mínimo, de acordo com o Decreto-Lei 399, de $1938^{44}$, confrontando-a com as necessidades reais de um indivíduo, de uma família. Nestes termos, o salário mínimo é

[...] a remuneração devida ao trabalhador, 'capaz de satisfazer as suas necessidades normais de alimentação, habitação, vestuário, higiene e transporte'. Não há referências a recreação, assistência médica, nem aos descontos feitos na folha de pagamento. Mas, mesmo os cinco itens do decreto - as necessidades normais - não podem ser atendidos pelo salário mínimo (DANTAS, 1971, p. 13, grifo do autor).

O narrador leva o leitor a refletir acerca da condição dos trabalhadores brasileiros. Devemos considerar, claro, que a revista tinha como público as classes média e alta do país. Portanto, os leitores viviam uma experiência de Brasil diferente daquela que se apresenta às personagens desta reportagem. Ao listar as cinco ditas 'necessidades normais' de um indivíduo, o texto reflete sobre a vida em sociedade e destaca aspectos que não foram considerados pelo decreto.

Podemos observar que as necessidades legais do sujeito estão diretamente ligadas com o próprio exercício de uma profissão. É necessário transporte para chegar à fábrica, bem como uma boa alimentação dá forças ao empregado para trabalhar. Ao pinçar o item 'assistência médica', o narrador dialoga diretamente com a situação de Joaquim e de sua família, onde todos os integrantes possuem alguma enfermidade. Essas estão atreladas, especialmente, às condições sanitárias do local; no entanto, a má alimentação também influencia a condição de vida das personagens. Além disso, o destaque dado ao termo 'necessidades normais' indica

\footnotetext{
${ }^{44}$ O primeiro salário mínimo era de 240 mil-réis, o equivalente a 24 centavos em 1971.
} 
um desacordo do narrador para com a definição. As necessidades, inclusive, não são 'básicas', mas, sim, 'normais'.

Ainda seguindo a lógica de contestação ao valor do salário mínimo, quando considerado o decreto-lei que o instituiu, o narrador descreve a interação entre Joaquim, sua família e a fome. Aqueles indivíduos nunca chegaram à fome absoluta, mas convivem com ela diariamente: tem de haver racionamento de comida, para que possam sobreviver ao longo dos dias. Há privação: carne e leite, por exemplo, são itens raros. "Desse jeito, Joaquim não pode cumprir nem um dos itens do decreto-lei que criou o salário mínimo" (DANTAS, 1971, p. 13).

A descrição dos detalhes do ambiente é um dos principais componentes da narrativa. Eles contribuem para a formulação mental do leitor acerca do ambiente. Ao demonstrar de que forma começa o dia de Joaquim, o narrador destaca determinadas ações que contribuem para entendermos como é o cotidiano daquela família:

\footnotetext{
Manhãzinha, na hora de sair para o trabalho, ele confere o dinheiro, uma cédulas sujas e amarrotadas, separa os 70 centavos do item transporte (ônibus, ida e volta, passagem a 35 centavos) e as rugas se acentuam em seu rosto. Só dispõe, tirando o dinheiro do ônibus, de 300 cruzeiros velhos, 30 centavos de hoje - mais do que era o primeiro salário mínimo do Brasil. Mas as coisas estão caras, um pãozinho custa 80 cruzeiros velhos, o dinheiro não dá para comprar um pão para cada um dos meninos.

- Lé, vai na padaria e traz três pão dos pequeno (DANTAS, 1971, p. 13, grifo do autor).
}

Cotidianamente, as rugas de preocupação afloram na face de Joaquim. Ele luta para sobreviver. Tem de pensar na família, na alimentação, em continuar na fábrica. Por mais que tenha consciência da situação difícil em que vive, o homem confere novamente a quantidade de que dispõe para o restante do mês. As despesas têm de ser pesadas, pensadas, medidas de acordo com a fome.

A partir da descrição dos valores, sem a necessidade de dizer que é impossível uma família viver apenas com o salário, o narrador dá a dimensão da preocupação do homem. Ele terá de conseguir ajuda externa para manter a família. $\mathrm{O}$ valor do transporte e a fome são ganchos para a fala destacada logo a seguir. Eles são sete pessoas, das quais seis precisam de alimentos sólidos.

No entanto, o menino vai comprar apenas três pães, e pequenos. A penúria, o racionamento, pode ser sentido logo ao acordar. A solução vem a seguir: "Clemente, 
Quelemente, Quelé, Lé: é o menino mais velho de Joaquim. Tem onze anos, é pequeno como um menino de oito, mas é esperto e rápido na hora de comprar comida. Num instante volta com os três pães que Ana, a mãe, reparte em seis" (DANTAS, 1971, p. 13). Ao repartir os pães, a mãe dá uma contribuição para amenizar a fome de cada um dos integrantes da família. Logicamente, esta ação exprime a relação daqueles indivíduos com a comida e a fome. Não comem visando saciar-se, mas sim esquecê-la por alguns momentos.

Quanto ao filho, Clemente, duas informações nos parecem importantes. Em primeiro lugar, ele é desnutrido. Não parece uma criança de sua idade. A falta de uma boa alimentação leva o menino a parecer cerca de três anos mais novo. Além disso, as demais condições físicas do local também levam as crianças a terem problemas desta natureza. Eles têm vermes, estão sempre doentes, o que também impossibilita o bom crescimento. Em segundo lugar, ele é esperto para conseguir comida. Em outras palavras, tem fome. A vontade de comer o leva à coragem para ir comprar o alimento. A fome é o combustível para a velocidade.

Os pães divididos seriam para todos os integrantes da família. Porém, Joaquim não come. O homem não sente fome, ou não tem vontade de comer, em função da situação. Prefere deixar a parcela que lhe cabe para que outro coma: quer seja a mulher, quer seja um dos filhos. No entanto, destaca-se a precariedade da situação. O homem segue para o trabalho sem se alimentar, para uma jornada de oito horas de trabalho pesado, podendo chegar a dez horas, caso tenha a 'sorte' de fazer duas horas extras. O sujeito conta com a ajuda de Deus para conseguir o dinheiro a mais. Tal ação manifesta o cristianismo que envolve a família, além de destinar a uma personagem imaterial a responsabilidade pela sorte.

O narrador agrega à condição de Joaquim uma informação que faz referência a todos os trabalhadores:

A alimentação deficiente é apontada com frequência como a principal causa
da improdutividade. Durante o I Encontro Governo-Empresa para a Solução
dos Problemas de Proteínas, realizado em maio do ano passado, no Rio, o
economista Julian Chacel, da fundação Getúlio Vargas, declarou que o
salário mínimo em vigor não permitia o consumo per-capta diário de 60
gramas de proteínas. Essa quantidade seria necessária a uma alimentação
equilibrada. Mas, para consegui-la, o trabalhador precisaria ganhar o
equivalente a quatro salários mínimos (DANTAS, 1971, p. 14).

Baseado em informações com respaldo científico, é apresentado ao leitor a implicação prática da alimentação inapropriada de Joaquim e de sua família. As reflexões, assim, passam por todos os integrantes do grupo: o homem não poderá trabalhar produtivamente, a mulher 
também não terá forças para lidar com as atividades de casa, bem como as crianças não poderão se desenvolver plenamente. O problema da má alimentação persegue as personagens, bem como advém de problemas anteriores e gera problemas no futuro. Ela faz parte do ciclo de vida das personagens. É consequência e gera consequências, ao mesmo tempo.

\subsection{Uma família narrada: a busca pelo sonho}

A última página dupla da reportagem (Figura 24) apresenta mais detalhadamente a vida de Joaquim. O título de página segue a mesma lógica daquele da página anterior. Há um encadeamento de informações. A família é regida por trabalho, fé e sonhos. Trabalha-se muito, esgotando as forças em busca de dinheiro e alimento. Ao mesmo tempo, a fé tem um papel de destaque: o homem pede a Deus que lhe proporcione a oportunidade de receber melhor remuneração. Ao mesmo tempo, o grupo tem o sonho de uma casa, nova e própria. Ter um lugar próprio, fugir do aluguel e das necessidades estruturais do ambiente é onde a personagem vislumbra a possibilidade de uma vida melhor.

Figura 24: Quem é o homem no fundo do poço?, Revista Realidade, $\mathrm{n}^{\circ}$ 58, jan. 1971, p. 14-15

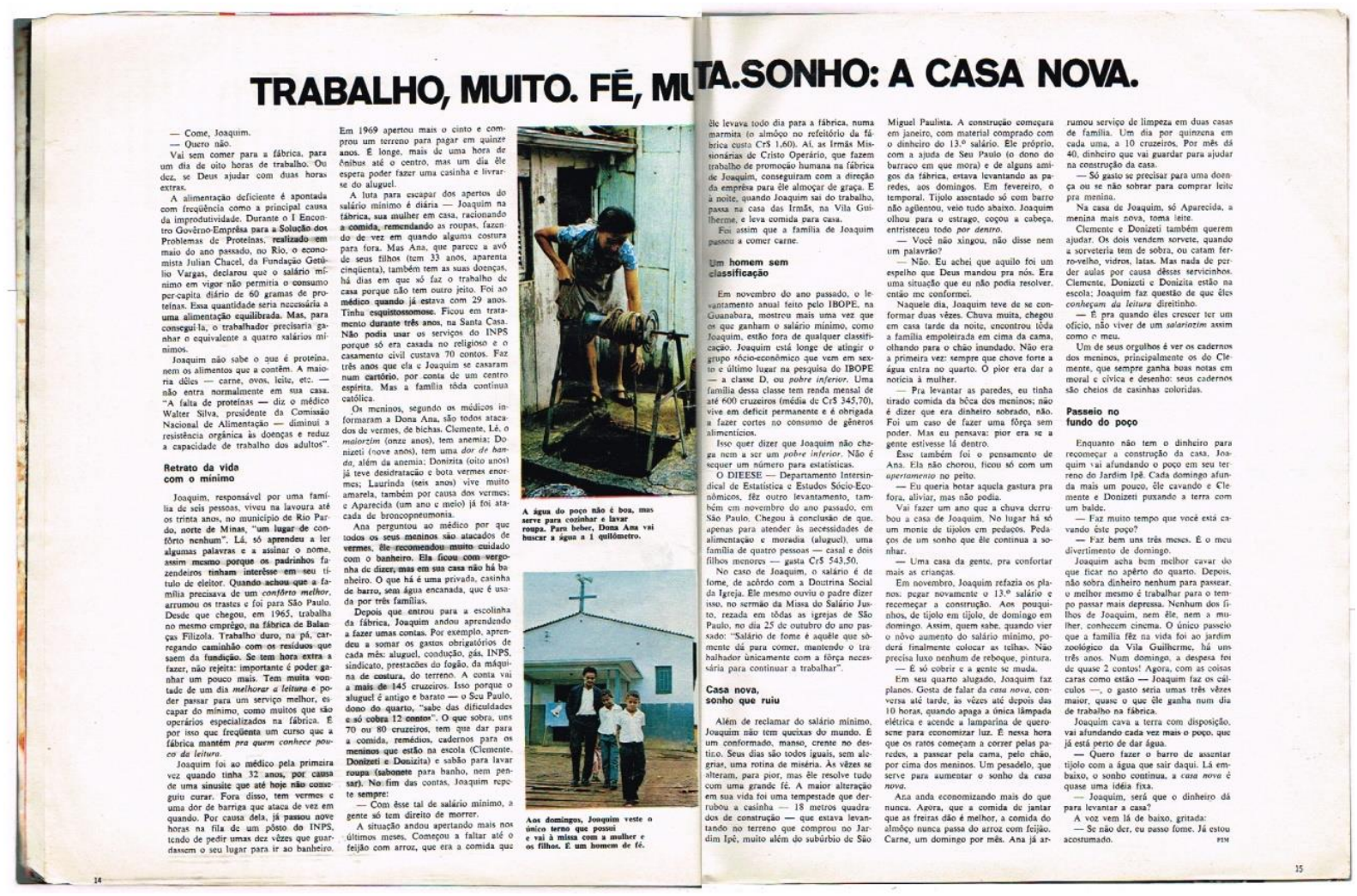

Fonte: Acervo do Grupo de Pesquisa Estudos Fotográficos (CNPq/UFCA) 
As fotografias que compõem a página dialogam com o título de página. Na primeira delas, na parte superior da página par, a mulher, Ana, realiza um trabalho braçal cotidiano: retira água de um poço cartesiano para realizar parte das atividades domésticas. No entanto, a água não é própria para o consumo direto, o que a leva a percorrer um quilômetro em busca da água potável. Mesmo sem uma boa alimentação, ela é obrigada a submeter-se a tal atividade. $\mathrm{O}$ esforço, o trabalho e a fé fazem parte da vida da família, em todas as instâncias.

$\mathrm{Na}$ fotografia localizada logo abaixo, Joaquim posa com os dois filhos mais velhos em frente a uma igreja. A legenda dá relevo à fé de Joaquim e, por consequência, de toda a família. $\mathrm{O}$ momento de ir à missa é solene, exige toda a pompa da melhor roupa disponível. A fé, como dito no título, é muita. O homem precisa apegar-se com um ser imaterial para seguir na luta diária pelo pão. Não há fé nos homens, mas sim em Deus. Necessita da ajuda divina para manter a família, para manter-se em vida.

O intertítulo da parcela de texto que apresenta a história de Joaquim tem duplo sentido: 'Retrato da vida com o mínimo'. O termo mínimo, além de referir-se ao salário mínimo, também pode ser entendido como o mínimo para a sobrevivência, em termos de alimentação, saúde, higiene, estrutura física e psicológica. Assim, o texto propõe-se a retratar, em detalhes, a vida sob condições extremas de pobreza, vivendo com menos que o mínimo necessário para uma vida digna.

Joaquim é um migrante dentro do próprio país. Saiu de Minas Gerais fugindo do trabalho na lavoura, no qual esteve até os 30 anos de idade. O texto aponta para a exploração de cunho coronelista que ainda existia no interior do Brasil: Joaquim sabe assinar o nome por conta do interesse dos fazendeiros, que vislumbravam nele e em muitos outros um voto de cabresto. Fugiu no norte de Minas em direção a São Paulo, buscando mais conforto para a família:

Quando achou que a família precisava de um conforto melhor, arrumou os trastes e foi para São Paulo. Desde que chegou, em 1965, trabalha no mesmo emprego [...] Trabalho duro, na pá, carregando caminhão com os resíduos que saem da fundição. Se tem hora extra a fazer, não rejeita: importante é poder ganhar um pouco mais. Tem muita vontade de um dia melhorar a leitura e poder passar para um serviço melhor, escapar do mínimo, como muitos que são operários especializados na fábrica (DANTAS, 1971, p. 14, grifo do autor). 
Joaquim submete-se à exploração, assim como muitos outros brasileiros. Sem uma alimentação digna, busca trabalhar ainda mais, em condições deploráveis. Pensa na família que está em casa, sem o que ele chama de 'conforto'. Sem as condições mínimas para sobreviver. Baseia a vida na possibilidade de receber mais dinheiro por seu esforço, pelo trabalho que, segundo o título de página, é muito. No entanto, Joaquim tem consciência de que a educação o levaria a uma condição melhor, de trabalho e de vida. Por isso não quer que os filhos saiam da escola, ou não tenham tempo para dedicar especial atenção aos estudos.

Neste aspecto, Joaquim dialoga diretamente com outra personagem já abordada por Realidade no ano anterior, 1970. Na edição de número 54, publicada em setembro daquele ano, a revista estampou a reportagem intitulada Eu sou João, homem sem leitura, com texto de José Hamilton Ribeiro e fotografias de Amâncio Chiodi. O texto narra a experiência de João de Sousa (68 anos), um analfabeto que vive em São Paulo. Assim como Joaquim, João vê na leitura a possibilidade de ter uma vida mais fácil, a partir da educação. Ambas as personagens buscam em cursos a possibilidade de crescer, de dar melhores condições de vida à família.

No quesito 'saúde', a situação de Joaquim não é menos preocupante que nos demais já abordados até aqui. A primeira vez que o homem visitou um médico foi aos 32 anos. A personagem carrega inúmeras doenças, tais como: sinusite, vermes e uma dor de barriga que não passa. Todos esses problemas são uma consequência do estado no qual a família mora. Sem condições minimamente adequadas de higiene, é natural que todos tenham problemas do tipo.

A apresentação daquele que é o sonho de Joaquim, a construção de sua casa, vem mesclada aos problemas que envolvem a situação atual do homem. A personagem não possui as condições ideais para adquirir um terreno, porém, o faz mesmo assim. Reduz ainda mais os gastos essenciais e decide comprá-lo, para pagar dentro de 15 anos. A intenção do homem é construir uma casa própria e não ter mais de despender boa parte do salário com o aluguel. No entanto, o terreno é distante do centro. Além disso, não há condições de construir. A família tem de submeter-se a uma conjuntura ainda mais extrema, racionando comida, eliminando gastos que seriam tidos como 'superficiais', tais como momentos de diversão ou mesmo cuidados com a saúde e a higiene.

O narrador classifica a situação cotidiana de Joaquim como um embate entre o homem e as condições que o envolvem: “A luta para escapar dos apertos do salário mínimo é diária Joaquim na fábrica, sua mulher em casa, racionando a comida, remendando as roupas, 
fazendo de vez em quando alguma costura para fora" (DANTAS, 1971, p. 14). Neste momento da narrativa, as ações de Ana assumem um papel de destaque. O homem trabalha na fábrica, ao passo que a mulher faz malabarismos em casa. As atitudes da mulher surgem no sentido de fazer render o salário mínimo de Joaquim, ao mesmo tempo em que busca possibilidades de contribuir diretamente com o parco sustento que entra em casa.

Ana, assim como todos os outros integrantes da família, também está doente. $\mathrm{Na}$ mesma proporção que o marido, a mulher foi pela primeira vez ao médico quando estava com 29 anos. A causa, esquistossomose. Não teve acesso aos serviços ligados ao INPS por não ser casada, oficialmente, com Joaquim. Mesmo assim, foram três anos de tratamento na Santa Casa. Com o episódio, perceberam a obrigatoriedade de um casamento. Contudo, o valor necessário para pagar o cartório não cabia no orçamento do casal, o que os levou a aceitar ajuda: "Faz três anos que ela e Joaquim se casaram num cartório, por conta de um centro espírita. Mas a família toda continua católica" (DANTAS, 1871, p. 14). Aqui, vemos a marcação religiosa. Os sujeitos autoafirmam suas convicções religiosas, por meio do narrador.

A penúria da situação reflete-se na saúde das crianças. Todas possuem alguma doença, em geral relacionadas com verminoses. Em visita ao médico, sem entender os motivos para a situação de saúde dos filhos, Ana questiona o profissional:

Ana perguntou ao médico por que todos os seus meninos são atacados de vermes, ele recomendou muito cuidado com o banheiro. Ela ficou com vergonha de dizer, mas em sua casa não há banheiro. O que há é uma privada, casinha de barro, sem água encanada, que é usada por três famílias (DANTAS, 1971, p. 14).

A personagem desconhece os cuidados que devem ser tomados quanto à higiene, a fim de que a família tenha boa saúde. No entanto, percebe as implicações negativas da situação na qual vive. Se sente vergonha de comunicar ao médico que não possui banheiro, percebe que aquela informação a expõe, põe à mostra a situação na qual vivem, ou sobrevivem. Ao trazer esta informação ao leitor, o narrador ainda traça mais algumas linhas do retrato daquele ambiente: não há condições mínimas de higiene, não há como elas existirem. Não há água, bem como não há a menor possibilidade de saneamento.

A educação, no texto, é tratada como um instrumento que leva a personagem a perceber a situação na qual vive. Antes de começar a estudar, Joaquim já imaginava que com a remuneração que recebe não fosse possível sobreviver, no entanto, após aprender a somar todos os seus gastos fixos, conclui: “- Com esse tal de salário mínimo, a gente só tem direito 
de morrer" (DANTAS, 1971, p. 14). Aqui lemos uma crítica explícita ao valor do salário mínimo. Antes feita embasada em dados oficiais, aqui a informação é posta como fala da própria personagem. $\mathrm{O}$ sujeito que sofre, que participa diretamente do embate, parece perder as esperanças quanto à sobrevivência com o mínimo. $\mathrm{O}$ valor, que deveria atender às necessidades ditas normais de um trabalhador, dá a ele apenas o 'direito' de morrer, não mais de viver ou sobreviver. Antes tido como um 'salário de sobrevivência', com o desenvolver do texto, passa ao que poderíamos chamar de 'salário de morte'.

No que tange à alimentação, o narrador descreve as dificuldades encontradas nos últimos meses. Começou a faltar os itens mais básicos, tais como feijão e arroz, na casa de Joaquim. A solução foi encontrada por meio das Irmãs Missionárias de Cristo Operário ${ }^{45}$. Elas intermediaram a relação dele com o refeitório da fábrica, de forma que pudesse realizar a refeição ali sem ser cobrado, ao mesmo tempo em que elas ainda fornecem algum alimento para que o homem leve para casa. Como fecho deste intertítulo, o narrador conclui: "Foi assim que a família de Joaquim passou a comer carne" (DANTAS, 1971, p. 15). Um primeiro passo, em direção ao sonho, foi dado.

Cambiando o tom da narrativa, o próximo intertítulo trata das classificações sociais realizadas por instituições como o Instituto Brasileiro de Opinião Pública e Estatística (IBOPE) e o Departamento Intersindical de Estatística e Estudos Socioeconômicos (DIEESE). Segundo o IBOPE, aqueles que ganham salário mínimo nem ao menos possuem uma classificação. De acordo com a reportagem,

Joaquim está longe de atingir o grupo sócio-econômico que vem em sexto e último lugar na pesquisa do IBOPE - a classe D, ou pobre inferior. Uma família dessa classe tem renda mensal de até 600 cruzeiros (média de Cr\$ $345,70)$, vive em déficit permanente e é obrigada a fazer cortes no consumo de gêneros alimentícios (DANTAS, 1971, p. 15, grifo do autor).

Joaquim recebe bem menos que um 'pobre inferior'. Não é contabilizado pelos números oficiais. Se um trabalhador que se encontra na classe D enfrenta os problemas descritos, especialmente destacados aqueles que se referem à alimentação, o narrador dá margem para o leitor perceber a situação de miséria na qual vivem as personagens desta reportagem. E, mais, todos aqueles que comungam da mesma miséria que Joaquim.

\footnotetext{
${ }^{45}$ Congregação criada por frei Luís Maria Sartori. O mesmo frei ainda fundou o Instituto dos Missionários de Cristo Operário e a Pastoral do Mundo do Trabalho.
} 
Indo além do levantamento do IBOPE, o DIEESE conclui, por meio de um estudo realizado em São Paulo, que um trabalhador necessitaria de Cr\$ 543,50, apenas para atender às necessidades de alimentação e moradia (para uma família composta por um casal e dois filhos). Nestas condições, faz-se praticamente impossível imaginar a situação na qual vive Joaquim. Por mais que o narrador nos dê detalhes do espaço, dos pensamentos, das ações para driblar o estado de fome, podemos entender que a situação é de miséria absoluta.

O repórter Audálio Dantas chegou até Joaquim por meio de uma nota sobre a Missa do Salário Justo, realizada no dia 25 de outubro de 1970. Em livro de memórias, Dantas descreve o caminho traçado, a fim de encontrar a personagem da reportagem que ora analisamos:

Parti em busca do "gancho" que seguraria a história. Encontrei-o numa pequena nota de jornal sobre os sermões da "missa do salário justo", rezada havia poucos meses nas igrejas católicas de São Paulo. Coisa da chamada Igreja Progressista, que começava a incomodar a ditadura militar. Missa como aquela só podia ser coisa de padre comunista. Ainda mais quando, do púlpito, os padre classificam o mínimo como salário de fome, ganho suficiente apenas para comer, para manter o trabalhador em pé, com "a força necessária para continuar a trabalhar" (DANTAS, 2012, p. 178).

A definição de 'salário de fome' também faz parte da reportagem. Ao dar destaque a tal informação, o narrador traz para a narrativa parte do ideário do clero de esquerda da época, forte contestador do estado autoritário. Ao utilizar como gancho um evento de cunho comunista, está indo, diretamente, contra o autoritarismo do governo. No entanto, o narrador tem o cuidado de não afirmar, diretamente, que o salário seria 'de fome'. O põe como uma afirmativa vinda do padre, ouvida por Joaquim. Portanto, é interiorizada pela personagem, que dá mostras, ao longo do texto, de concordar com a opinião dos padres.

O próximo intertítulo, 'Casa nova, sonho que ruiu', vem a contribuir com a descrição psicológica da personagem. Neste ponto, o texto passa a tratar da relação de Joaquim com a fuga do salário mínimo, da miséria na qual vive. Joaquim mostra-se um sujeito que, apesar de perceber os problemas, torna-se resignado, fazendo poucas afrontas à situação. Vejamos o trecho a seguir:

Além de reclamar do salário mínimo, Joaquim não tem queixas do mundo. É um conformado, manso, crente no destino. Seus dias são todos iguais, sem alegrias, uma rotina de miséria. Às vezes se alteram, para pior, mas ele resolve tudo com uma grande fé. A maior alteração em sua vida foi uma tempestade que derrubou a casinha - 18 metros quadrados de construção que estava levantando no terreno que comprou no Jardim do Ipê, muito além 
do subúrbio de São Miguel Paulista. [...] Tijolo assentado só com barro não aguentou, veio tudo abaixo. Joaquim olhou para o estrago, coçou a cabeça, entristeceu todo por dentro (DANTAS, 1971, p. 15, grifo do autor).

A casa nova, descrita no título de página como um sonho, tem a sua primeira aparição no texto. No entanto, seguindo a lógica de problemas não resolvidos e da falta de estrutura, já tomamos conhecimento da mesma em forma de ruínas. O sonho já está desabado, desestruturado. Até para realizar o ato de sonhar a personagem enfrenta dificuldades. Ao classificar a vida de Joaquim como uma 'rotina de miséria', o narrador enfatiza o caráter contínuo da situação da personagem.

O terreno para a construção da casa será pago ao longo de 15 anos. Durante este tempo, o homem terá de redirecionar parte do dinheiro referente à alimentação das crianças, dele próprio e da mulher para o pagamento das prestações. Portanto, temos em mãos um sofrimento adicional à condição já débil de Joaquim. Para além dos problemas vindos do mundo em sociedade, há ainda condições ambientais que dificultam a vida da personagem.

Para construir a casa, agora em ruinas, a personagem teve de destinar o $13^{\circ}$ salário para a compra do material de construção. Ele próprio começou a levantar as paredes. Nestas condições, a baixa condição de renda leva ao racionamento, também, dos materiais. A falta de estrutura conduz à dupla ruína, da casa e do homem. Apesar de conformar-se com a situação, o homem entristece-se com aquilo que veio de Deus, do destino. Aquilo que sua fé não pode prever ou contornar. Joaquim abaixa a cabeça e segue, vivenciando os problemas que fazem parte do cotidiano.

O repórter enquanto personagem surge, mais uma vez, na narrativa, questionando Joaquim sobre a sua reação ao acontecimento, reforçando a construção psicológica da personagem enquanto uma pessoa resignada ao destino: “- Você não xingou, não disse nem um palavrão? - Não. Eu achei que aquilo foi um espelho que Deus mandou pra nós. Era uma situação que eu não podia resolver, então me conformei" (DANTAS, 1971, p. 15). O que agora surge como uma tristeza, um desalento, se poderia transformar em uma catástrofe, caso a família se encontrasse no interior da casa no momento do acidente. A própria personagem assume o ato de conformar-se como a única opção que lhe resta. Não fosse isso, o que poderia fazer? Não há dinheiro, não há outra opção para a construção da casa.

Ao chegar ao quarto no qual mora, no mesmo dia em que se deparou com a futura casa desmoronada, o homem encontra a família posta em cima da cama, fugindo da água que inundou o local. Mais uma vez resignado aos problemas, Joaquim não se vê surpreendido pela 
situação. No entanto, ambos os integrantes do casal sofrem, silenciosamente, pela ruina do sonho:

- Pra levantar as paredes, eu tinha tirado comida da boca dos meninos; não é dizer que era dinheiro sobrado, não. Foi um caso de fazer uma força sem poder. Mas eu pensava: pior era se a gente estivesse lá dentro.

Esse também foi o pensamento de Ana. Ela não chorou, ficou só com um apertamento no peito.

- Eu queria botar aquela gastura pra fora, aliviar, mas não podia (DANTAS, 1971, p. 15, grifo do autor).

Mesmo sem a indicação de qual das personagens realiza cada fala, podemos perceber que a primeira das assertivas provém de Joaquim, ao passo que a segunda se refere à Ana. $\mathrm{O}$ tal 'apertamento' no peito, do qual a mulher trata, é angústia. O fato de deparar-se com um problema sem solução gera a sensação de impotência. O dinheiro, desviado com tanto pesar, agora está reduzido a escombros. Observando a situação por ambos os lados, o eixo do problema gira em torno das crianças. A justificativa para a construção da casa é dar conforto para os filhos, ao mesmo tempo em que o pesar pelo dinheiro mal empregado vem por conta da consequente má alimentação dos meninos. Mas o sonho não deixa de existir:

Em novembro, Joaquim refazia os planos: pegar novamente o $13^{\circ}$ salário e recomeçar a construção. Aos pouquinhos, de tijolo em tijolo, de domingo em domingo. Assim, quem sabe, quando vier o novo aumento do salário mínimo, poderá finalmente colocar as telhas. Não precisa luxo nenhum de reboque, pintura (DANTAS, 1971, p. 15).

O luxo, apresentado pela narrativa, refere-se, também, a uma questão de saúde. Sem o reboque, por exemplo, a probabilidade de proliferação de doenças aumenta. Em tese, não temos um luxo, mas sim uma necessidade. Vista pela personagem como algo dispensável, percebemos que não há informações acerca dos requisitos mínimos para a manutenção da saúde da família. Apesar dos problemas encontrados no ano anterior, a família mantém a casa como um sonho, um objetivo a ser alcançado. Mesmo resignando-se ao destino, Joaquim insiste em repetir, nos mesmos parâmetros que o fez no ano anterior, a busca pela construção. Utilizará os supostos dias de descanso, vai deixar de adquirir comida a fim de comprar parte do material. No entanto, ainda depende do destino para tornar a casa completa: o telhado só será feito caso haja uma renda mensal adicional.

Os perigos da vida naquele quarto estão presentes, de forma observável: 
Em seu quarto alugado, Joaquim faz planos. Gosta de falar da casa nova, conversa até tarde, às vezes até depois das 10 horas, quando apaga a única lâmpada elétrica e acende a lamparina de querosene para economizar luz. É nessa hora que os ratos começam a correr pelas paredes, a passear pela cama, pelo chão, por cima dos meninos. Um pesadelo, que serve para aumentar o sonho da casa nova (DANTAS, 1971, p. 15, grifo do autor).

Para além dos animais proliferadores de doenças que passeiam, livremente, entre os moradores do barraco, há também o uso do querosene. Naquelas condições, a possibilidade de um incêndio acidental se acentua. Além disso, por mais que a personagem de Joaquim seja descrito como um sujeito condicionado pelo meio, em algumas passagens podemos perceber que ele nutre o desejo de mudar sua vida e a da família. Joaquim percebe as deficiências do local no qual vive, bem como nota as implicações do salário que recebe. Porém, não consegue visualizar outra forma de trabalho, de sobrevivência. A causa para tal problemática se refere à inexistência de educação formal, por parte da personagem.

Ana também trabalha, esforça-se para aumentar a renda da casa. Raciona a comida, especialmente após a contribuição das freiras. Agora, o almoço é sempre arroz com feijão, apenas. Carne, um luxo, só pode ser consumido uma vez ao mês, no domingo. Além do trabalho interno ao lar, Ana também trabalha como diarista, fazendo limpeza em duas casas, duas vezes por mês. No total, um rendimento extra de 40 cruzeiros. A personagem pretende guardar o dinheiro para ajudar na construção da casa. Em meio aos problemas que assolam a família, as crianças também se mostram dispostas a ajudar:

Clemente e Donizeti também querem ajudar. Os dois vendem sorvete, quando a sorveteria tem de sobra, ou catam ferro-velho, vidros, latas. Mas nada de perder aulas por causa desses servicinhos. Clemente, Donizeti e Donizita estão na escola; Joaquim faz questão de que eles conheçam da leitura direitinho (DANTAS, 1971, p. 15, grifo do autor).

Retomando um aspecto já tratado anteriormente, a personagem destaca a importância da educação para que a exploração dos trabalhadores se dê de uma forma menos intensa. Caso dominem a leitura, as crianças terão a possibilidade de fugir do salário mínimo. Nos termos do próprio Joaquim: “- É pra quando eles crescer ter um ofício, não viver de um salariozim assim como o meu" (DANTAS, 1971, p. 15, grifo do autor). O pai sente orgulho dos filhos, acompanha o preenchimento dos cadernos. O futuro dos meninos está traçado naquelas linhas.

O trecho de encerramento da reportagem está escrito sob o seguinte intertítulo: 'Passeio no fundo do poço'. A personagem de Joaquim vive mergulhada em dívidas e 
preocupações. Sua vida já pode ser considerada o 'fundo do poço'. Porém, enquanto não possui dinheiro para dar continuidade à construção da casa, o homem cava o poço que trará água para a sua família, na já falada 'casa nova'.

A personagem utiliza aquele momento como uma fuga em relação às dificuldades que enfrenta, diariamente. Para ela, aquele é um instante de divertimento: "Joaquim acha bem melhor cavar do que ficar no aperto do quarto. Depois, não sobra dinheiro nenhum para passear, o melhor mesmo é trabalhar para o tempo passar mais depressa” (DANTAS, 1971, p. 15). O trabalho consome a vida da personagem. Trabalhando, o tempo se esvai. Ela não intenta aproveitar, descansar. O ócio leva ao pensamento. Pensando, observará a quantidade de problemas que a envolve. Prefere não pensar, concentrar-se no trabalho, em sonhar com a 'casa nova'.

Em uma última intervenção do jornalista enquanto personagem da narrativa, ele questiona Joaquim acerca da viabilidade da construção da casa:

- Joaquim, será que o dinheiro dá para levantar a casa?

A voz vem lá de baixo, gritada:

- Se não der, eu passo fome. Já estou acostumado (DANTAS, 1971, p. 15).

A fome e a miséria, assim, consolidam-se enquanto elementos que compõem o cenário imaterial da reportagem. O clima de tensão e desconforto é acalentado pelas características de resignação de Joaquim. A narrativa, assim, expõe a situação de penúria na qual vivem os assalariados, dando, para além dos dados, um rosto, uma expressão. O homem e sua família lutam, diariamente, para sobreviver com o mínimo. 


\section{NARRATIVA V: 30 DIAS NA ILUSÃO DO GARIMPO}

As condições de trabalho em um garimpo de diamantes, como podemos imaginar, são duras. São horas com as pernas mergulhadas no rio, o sol quente sobre as cabeças, os perigos de se lidar com objetos demasiado valiosos. Porém, todas estas são suposições que podemos fazer, baseadas nas nossas experiências de vida. No caso específico desta reportagem, publicada no número 65 de Realidade, em agosto de 1971, o repórter José Leal foi até um garimpo, no estado de Goiás, e viveu como um garimpeiro durante 30 dias.

A chamada na capa da revista traz os seguintes dizeres: "Conheci o inferno: fui garimpeiro". Numa primeira leitura, podemos perceber que o texto trará um relato do repórter, ao assumir que foi garimpeiro, em primeira pessoa. Indo mais fundo nesta leitura, a personagem-autor faz uma comparação direta entre o garimpo e o inferno. Garimpo, assim, seria um espaço destinado ao castigo, ao sofrimento eterno, a um tormento diário.

No ano anterior, 1970, havia sido lançada a novela Irmãos Coragem, de autoria de Janete Clair. Sob a direção de Daniel Filho e contando com as atuações de Tarcísio Meira, Glória Menezes, Regina Duarte, Cláudio Cavalcanti e Cláudio Marzo, entre outros, a telenovela abordou a vida no garimpo. Encenada na cidade fictícia de Coroado, no interior goiano, as personagens têm suas vidas costuradas pela exploração de minérios. A novela foi ao ar entre oito de junho de 1970 e 12 de junho de 1971 e logo nos primeiros capítulos atingiu a marca de $85 \%$ de audiência. Portanto, a reportagem foi publicada menos de dois meses após o fim do folhetim.

De acordo com o sítio Memória Globo,

Em 1970, enquanto o Brasil conquistava o tricampeonato de futebol na Copa do Mundo do México e presos políticos eram torturados pelo regime militar, Janete Clair se consagrava como novelista com um faroeste que fazia uma analogia entre a realidade política do país e o poder arbitrário de um coronel 
na fictícia Coroado, localizada na divisa de Minas Gerais com Goiás, e cuja principal atividade econômica é o garimpo. O despótico latifundiário Pedro Barros (Gilberto Martinho) quer controlar o comércio de diamantes na região e, para isso, corrompe a polícia, compra votos e oprime a população, tendo sob seu comando um grupo de jagunços. Contra seu poder se insurgem João (Tarcísio Meira), Jerônimo (Cláudio Cavalcanti) e Duda (Cláudio Marzo), os irmãos Coragem, filhos de Sebastião (Antônio Vitor) e Sinhana (Zilka Sallaberry) (IRMÃ̃S...).

José Leal, antes de trabalhar para a Editora Abril, fez parte do quadro de repórteres do jornal $O$ Globo. Naquele veículo, no ano de 1957, foi contemplado com o Prêmio Esso de Jornalismo, na categoria Principal. O trabalho premiado, intitulado "Cem dias na fronteira da loucura", é uma

Dramática narrativa do repórter como interno numa clínica de tratamento de alcoólatras, editada em uma série de reportagens que, didaticamente, expõe a questão do confinamento da pessoa humana em comunidades controladas. O relato autobiográfico adquire o sentido de uma dolorosa confissão e se constituiu num libelo contra os abusos a que eram submetidos os pacientes (1957, PRÊMIO PRINCIPAL).

Os dois textos citados, de autoria de José Leal, trazem o testemunho como principal característica da narrativa. Podemos notar, por meio do título escolhido para a reportagem aqui analisada, certa valoração dada ao garimpo: ali, trabalho e ilusão podem ser tomados como sinônimos. O espaço físico onde se garimpa, denominado garimpo, bem como o trabalho, também subjetivado por meio do termo garimpo, são adjetivados como uma ilusão. As pessoas procuram estes ambientes em busca de fortuna, mas acabam percebendo que encontrar uma pedra preciosa é difícil. Porém, manter-se vivo também passa a ser uma tarefa complicada e que depende, em boa parte, da relação estabelecida com os outros, o que também pode ser uma farsa, uma ilusão.

\subsection{Entre o trabalho e a ilusão: vida e morte no garimpo}

De acordo com o Dicionário Houaiss da língua portuguesa, ilusão é "1 erro de percepção ou de entendimento; engano dos sentidos ou da mente; interpretação errônea 1.1 confusão de aparência com realidade 1.2 confusão de falso com verdadeiro". Desta forma, aqueles que se dirigem para o garimpo fazem uma leitura errada das possibilidades ali 
encontradas, bem como, quando se deparam com alguma pedra, podem confundir a realidade da miséria com a felicidade passageira da riqueza.

No texto de abertura da reportagem de Realidade, sobreposta à fotografia de abertura, há uma apresentação do texto, destacando-se o papel e a forma de atuação do repórter de texto: “O repórter José Leal passou um mês garimpando no rio Jaraguá, em Aragarças, Estado de Goiás. Durante esse tempo, conseguiu achar dois xibius (diamantes sem valor), sentiu a miséria em que vive essa gente e quase encontrou a morte" (LEAL, 1971, p. 29).

Ao mesmo tempo em que aponta para a presença do repórter enquanto personagem da narrativa, a abertura ressalta três especificações daquele labor: 1) após um mês de trabalho, a personagem encontrou apenas duas pedras, ambas sem valor comercial; 2) a comunidade à qual ele se dirigiu vive na miséria, de forma que em um mês ele consegue sentir o sofrimento que a envolve, os problemas sociais, físicos e psicológicos; e 3) a morte: pode ter sido um acidente ou uma briga - o leitor, neste ponto, faz conjecturas acerca da possível morte, mas sabe que ela faz parte do contexto, uma vez que foi citada na abertura, encerrando, em clima de suspense, a apresentação.

Figura 25 - 30 dias na ilusão do garimpo, Revista Realidade, nº 65, ago. 1971, p. 28-29

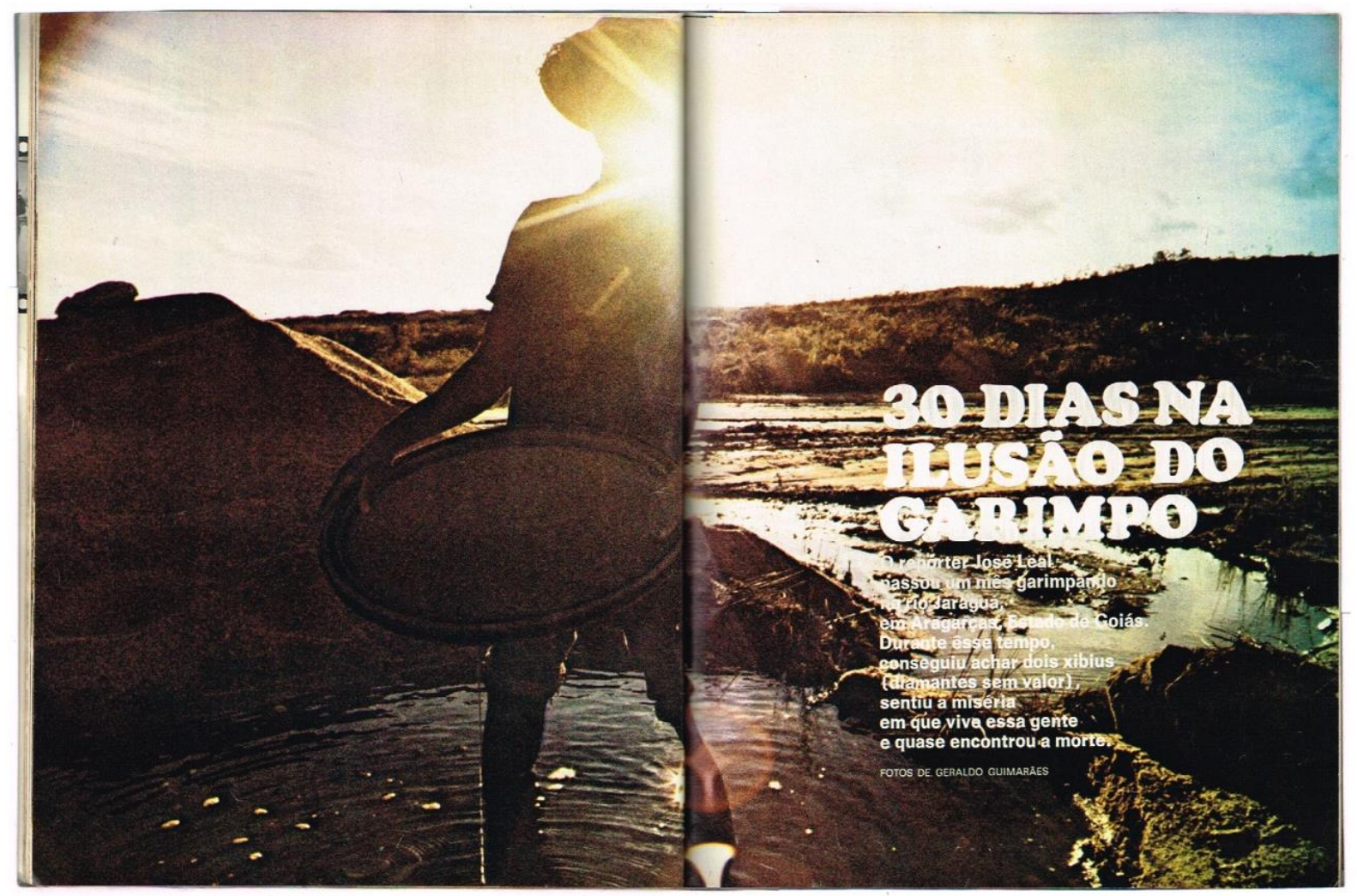

Fonte: Acervo do Grupo de Pesquisa Estudos Fotográficos (CNPq/UFCA) 
A fotografia que abre a reportagem (Figura 25), em página dupla, é primeiro contato visual do leitor com o cenário da reportagem. A imagem chama a atenção pelo tom de marrom, quebrado apenas por uma pequena parcela do céu azul. O marrom, que remete ao solo do cerrado, impregna a vida do garimpeiro. Estando boa parte do dia com os pés mergulhados no rio, lidando cotidianamente com as pedras e sendo suas roupas ali lavadas, as indumentárias das pessoas que moram e/ou trabalham com o garimpo assumem um tom avermelhado, próximo ao marrom, como veremos nas próximas imagens.

A fotografia, além disso, encobre, por intermédio da luz do sol, o rosto, a identidade do garimpeiro. Na contraluz, podemos observar a silhueta da personagem: traja calças dobradas até a altura do joelho, seus pés e pernas estão mergulhados no rio, tem nas mãos uma das peneiras utilizadas para separar as pedras dos diamantes, usa uma camisa folgada e um chapéu para se proteger do sol.

A luminosidade, elemento cotidiano, impede de vermos o rosto da personagem, aquele ambiente torna todos os homens iguais. Eles não possuem um rosto, não possuem espaço, não possuem passado ou futuro. Fazem parte do ambiente. Este homem representa o inferno, a miséria, a morte, já tratados até aqui. A peneira, sendo segurada pelas duas mãos, é o elo entre o homem e o meio, entre o garimpeiro e o garimpo.

Sobre a fotografia, vemos o texto de abertura já mencionado. As letras brancas, sobre o fundo colorido, tornam a leitura difícil, em alguns pontos. O nome do rio onde o repórter vai garimpar e o nome da cidade, por exemplo, exigem certo esforço do leitor, no sentido de identificar as palavras. Ao mesmo tempo, o texto, 'mergulhado' nas poças de água da fotografia, dialoga com a situação na qual vivem aquelas pessoas: pouco assistidas pelo Estado, especialmente no que se refere à saúde e à segurança; sumindo em meio à miséria que vem do rio e daqueles que buscam nele a esperança de dias melhores.

O primeiro título de página da reportagem (Figura 26) segue a mesma trilha de suspense do encerramento da apresentação: "Entrei no Jaraguá. É de meter medo" (LEAL, 1971, p. 31). Seguindo uma fórmula de ação e reação, por meio de frases curtas, o autor marca o caráter da narrativa: o medo é uma palavra, e um sentimento, que vai permear toda a passagem do jornalista pelo garimpo. Desde a relação com os demais garimpeiros até a reação estabelecida a partir da narrativa local, povoada por mortes, vingança e violência, o sentimento é de medo e desconfiança.

O texto não segue o tempo cronológico, mas sim o psicológico, especialmente por relatar um vasto intervalo de tempo. Sendo assim, a reportagem tem início com algo que, 
como veremos, será comum ao longo do texto: a descrição de uma morte no garimpo. A cena acontece em um dia no qual o repórter já está trabalhando como garimpeiro, já conhece seus companheiros. Vejamos o primeiro parágrafo do texto, composto por apenas quatro linhas: "Lurdinha tinha nove anos e estava nadando num riacho, a 200 metros do garimpo do seu pai, quando foi estuprada por Mané do Cacau" (LEAL, 1971, p. 31).

Figura 26 - 30 dias na ilusão do garimpo, Revista Realidade, $\mathrm{n}^{\mathrm{o}}$ 65, ago. 1971, p. 30-31

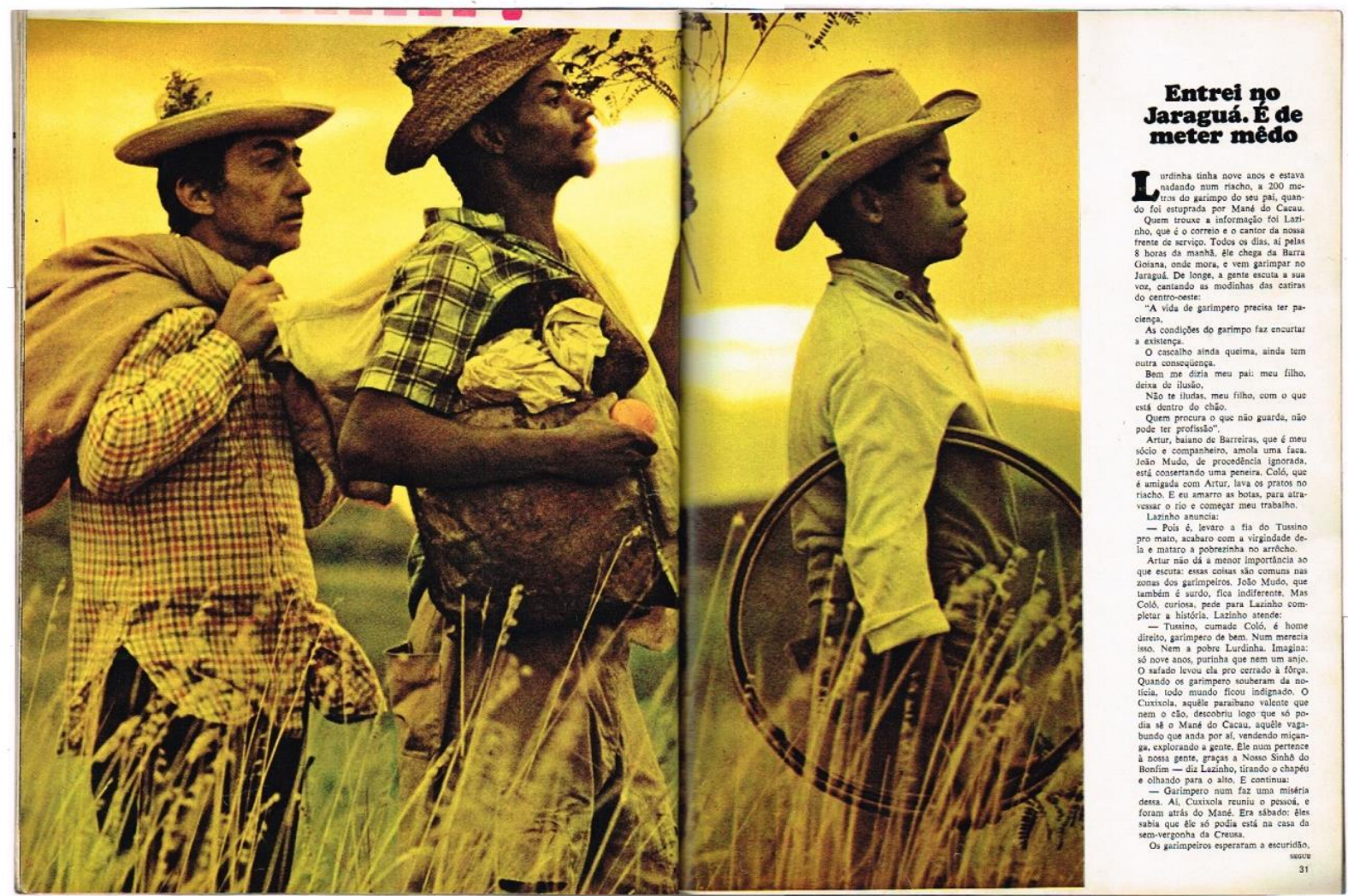

Fonte: Acervo do Grupo de Pesquisa Estudos Fotográficos (CNPq/UFCA)

A notícia, assim resumida, dá início à reportagem, contribuindo para a construção de uma primeira imagem do garimpo, permeado por narrativas de violência e morte. Neste local, nem as crianças são livradas daqueles que querem fazer o mal. No entanto, os próprios garimpeiros, dando elementos que vão compor a identidade do que é 'ser garimpeiro', afirmam que a atitude de estuprar e matar uma criança não seria tomada por um trabalhador do garimpo. Ao continuar a narrativa do crime, Lazinho, um dos garimpeiros do grupo do repórter, as qualidades de um garimpeiro: 
- Tussino, cumade Coló, é home direito, garimpeiro do bem. Num merecia isso. Nem a pobre Lurdinha. Imagina: só nove anos, purinha que nem um anjo. O safado levou ela pro cerrado à força. Quando os garimpero souberam da notícia, todo mundo ficou indignado. O Cuxixola, aquele paraibano valente que nem o cão, descobriu logo que só podia sê o Mané do Cacau, aquele vagabundo que anda por aí, vendendo miçanga, explorando a gente. Ele num pertence à nossa gente, graças a Nosso Sinhô do Bonfim - diz Lazinho, tirando o chapéu e olhando para o alto. E continua:

- Garimpero num faz uma miséria dessas (LEAL, 1971, p. 31, grifo nosso).

Assim descrito, o narrador aponta para a autoidentificação que ocorre dentro do grupo, de forma que eles próprios definem o que é ou não a atitude de um garimpeiro. A relação de pertencimento ao grupo contribui para fortalecer os indivíduos em meio ao ambiente inóspito que se torna o garimpo, repleto de incidentes que resultam na morte, em especial, dos próprios garimpeiros. A ganância e a violência parecem caminhar juntas em meio aos braços do rio Jaraguá. O que determina as ações que são consideradas, pelo grupo, atos de violência, são os valores sociais, culturais, econômicos, políticos e morais do próprio grupo.

Além desta característica psicológica que engloba os garimpeiros, há ainda as condições de vida e trabalho, também compartilhadas. No texto, a primeira apresentação sobre o contexto social se dá por meio de uma canção, uma modinha, entoada por Lazinho:

A vida de garimpeiro precisa ter paciença, / As condições do garimpo faz encurtar a existença. / $\mathrm{O}$ cascalho ainda queima, ainda tem outra consequença. / Bem me dizia meu pai: meu filho, deixa de ilusão, / Não te iludas, meu filho, com o que está dentro do chão, / Quem procura o que não guarda, não pode ter profissão (LEAL, 1971, p. 31).

Por 'condições do garimpo', podemos entender tanto aquelas que dizem respeito à saúde quanto ao perigo advindo da inveja e da ganância, gerando violência. Para além das problemáticas envolvidas com o caráter do próprio homem, há ainda aquilo que procede da natureza: o contínuo mexer com as pedras e a terra, o cascalho, maltrata as mãos e os pés do garimpeiro, fazendo-os queimar, numa reação biológica ao constante atrito.

Em consonância com o título dado à reportagem, o pai alerta o filho para a ilusão que é o garimpo, uma vez que, assim como as pedras que ficam escondidas no chão, os perigos podem estar escondidos nas pessoas com as quais se convive, com os 'não-garimpeiros'. Assim como há uma relação de pertencimento que une os seres, há uma relação de nãopertencimento com o objeto do desejo de cada um deles, o diamante. Eles buscam a riqueza, mas não sabem exatamente onde encontrá-la. Dependem da sorte (para encontrar uma pedra), 
da perseverança e da sorte novamente (para conseguir manter-se com ela, vendê-la e sair do garimpo).

Ao serem introduzidos no texto, as personagens que seguirão junto ao repórter durante os dias no garimpo expressam suas diferentes reações ao relato da morte. Artur, sócio da personagem-narrador, não dá importância ao fato, posto que seja considerado normal; João Mudo, sujeito mudo e surto, mantém-se indiferente; Coló, mulher de Artur, mostra-se curiosa e questiona Lazinho por mais detalhes do incidente (LEAL, 1971, p. 31).

A estória de Lurdinha é concluída por meio da morte de seu assassino. Cria-se uma narrativa circular, onde uma morte leva, naturalmente, a outra. A banalização da vida é tida, pelas personagens, como uma forma de vingança. A primeira morte, não justificável em si, serve de justificativa para a segunda. Numa atitude de justiça com as próprias mãos, Cuxixola, um 'paraibano valente', descobre o agressor e vai, juntamente com outros garimpeiros, em busca daquele que, em essência, não é considerado um.

Dizemos isso, pois, em algumas passagens, as personagens que são, efetivamente, garimpeiros, fazem afirmações sobre a forma como se porta um verdadeiro garimpeiro, ou sobre o que seria uma atitude de alguém que não pertence àquele grupo. Sobre a forma como Lurdinha foi assassinada, Lazinho afirma: “- Garimpeiro num faz uma miséria dessas” (LEAL, 1971, p. 31).

Em virtude do caráter de vingança socialmente justificada, os garimpeiros estão autorizados pelo grupo a armarem uma tocáia, uma armadilha para o assassino. Eles esperam a noite chegar, sabem que o homem estará na casa de uma prostituta e vão até lá. Segundo o narrador deste causo, a madrugada é o melhor horário para se praticar justiça no ambiente do garimpo (LEAL, 1971, p. 33). Como não existe outro meio de segurança naquele espaço, não se pode contar com a justiça oficial, com a polícia, os homens 'de bem' do garimpo, aqueles mais corajosos, com um senso do que seria certo ou errado, para aquele ambiente, são os responsáveis por vingar a morte dos inocentes.

A precisão no relato é explicitada por meio dos dêiticos e dos detalhes. Um exemplo é a descrição da busca por Mané do Cacau. Os homens o esperam no meio da madrugada, cercam o barraco de Creusa às $2 \mathrm{~h} 55$, armados, e começam a interrogar o suspeito, em busca de uma confissão. Faz-se interessante observar que os garimpeiros já abordam o suspeito com a certeza de que ele é o culpado. Buscam a confissão apenas para, em seguida, matarem o homem. Vejamos a descrição da abordagem de Cuxiola a Mané do Cacau: 
[Cuxixola] Encostou o revólver na cara de Mané do Cacau e disse:

- Por que você fez aquilo com a fia do Tussino? Diga logo, safado.

Mané confessou e pediu clemência. Cuxixola empurrou o revolver no ouvido dele e deu três vezes no gatilho. Os outros três tiros foram no peito.

- Então - continua Lazinho no seu relato -, cada um dos homi deu mais um tiro. Depois arrastaro o corpo dele até a beira do rio. E Mané do Cacau foi engolido pela água. Ninguém viu e, se viu, num falou. (LEAL, 1971, p. 33, grifo nosso)

O poder que a personagem de Cuxixola exerce sobre Mané do Cacau está calcado em dois fatores: 1) ele possui a fama de ser valente e 2) detém um objeto que transfere para ela a autoridade da situação, a arma, completamente carregada. Conjugados, os dois elementos fazem com que o homem confesse o crime. Mesmo que não fosse ele o culpado, provavelmente a atitude do suspeito seria a mesma. O medo o faz confessar e, em seguida, pedir clemência. Esse fato reforça a ideia de que nunca saberemos se o homem foi, de fato, o responsável pela morte de Lurdinha.

Contudo, a dúvida está posta apenas para nós, leitores. Os homens estão absolutamente seguros de suas ações. O responsável pelo grupo defere seis tiros no corpo do assassino. Não há piedade. As ações são descritas com sangue frio. Sendo assim, temos uma cena de tortura seguida de assassinato. Em um terceiro momento, há a ocultação do cadáver. Mesmo que encontrado, um dia, não se saberá quem foi o responsável pelo crime. E também não haverá indício do motivo para tal crime. Não há testemunhas.

A fim de eximir-se do relato, o narrador explicita, ao longo da narrativa, que aquela descrição fria dos acontecimentos não está sendo feita por ele, mas por Lazinho, um homem do garimpo. Assim, o repórter-personagem tira de si uma possível valoração acerca daquelas atitudes e ações.

A construção que o narrador traça para as relações de convívio dentro do garimpo conjuga o constante relato da morte e, por conseguinte, o cultivo do medo. Enquanto Lazinho terminava o relato das duas primeiras mortes descritas no texto, uma nova personagem chega à cena: João Mascarenhas. Impulsionado pelo relato do outro garimpeiro, faz um comentário sobre a situação (dando relevo ao estado de medo constante). Ao comentar, utiliza mais um crime como exemplo: “- Num se pode mais garimpá nesta terra. Na sumana passada, Zequinha de Floriano tava lavano cascaio, apareceu um desconhecido, deu seis tiro nele. Matô pra robá, ninguém sabe quem foi” (LEAL, 1971, p. 33). Relações obscuras envolvem as cenas de crimes. Podemos perceber, pela forma como a personagem relata o ocorrido, que Zequinha de Floriano era um garimpeiro, aceito enquanto tal pelos pares. As circunstâncias de sua 
morte apontam para um dos motivos que levam ao medo que colore a narrativa: como aqueles homens trabalham com objetos de valor, o roubo é iminente.

\subsection{A chegada ao garimpo: construindo uma personagem}

Entendemos que o narrador julga os crimes que culminam em mortes um fator de extrema importância para a descrição do ambiente do garimpo. A primeira parte do texto, conforme vimos até aqui, trata exclusivamente da apresentação de algumas das personagens principais e do relato de três mortes. A partir deste ponto, sem que haja um subtítulo ou algo que indique o retorno no tempo cronológico, o narrador passa a relatar seu primeiro contato com a região, no momento em que chega ao aeroporto. $\mathrm{O}$ repórter se dirige à cidade de Aragarças. O relato da chegada é feito em primeira pessoa do singular. A personagem descreve desde a visão que tem a partir da janela do avião, até às roupas que está trajando.

O homem que chega aquele dia a Aragarças parece já ter estado ali outras vezes, provavelmente na década de 1950 . No entanto, como forma de manter a personagem que cria para si, e mesmo para começar a interagir com o meio, expressa total desconhecimento em relação à cidade:

\footnotetext{
Às 9 horas e 5 minutos, a cidade parece ainda estar dormindo, quando o avião chega ao aeroporto de Aragarças. Pela janela de bordo vejo que nada mudou. A estação de passageiros é a mesma de vinte anos atrás: uma casinhola branca sem qualquer atração. Desce pouca gente aqui, umas quatro pessoas. O meu tipo não desperta a atenção de ninguém: visto um blusão azul, calças da mesma cor, ambos muito surrados. No balcão da Vasp, peço à recepcionista que me indique uma pensão qualquer, onde eu possa ficar alguns dias. Mas que não seja cara (LEAL, 1971, p. 33, grifo nosso).
}

A recepcionista, ao responder ao questionamento do desconhecido, faz uma revelação sobre a cidade. Ela diz que, ali, tudo é bom e ruim ao mesmo tempo. Podemos ler no comentário uma visão que traduz aquela comunidade: em todas as ações e ambientes vai sempre haver um lado positivo e um lado negativo. Tanto as pessoas como os objetos são dúbios. $\mathrm{O}$ medo e a esperança convivem.

Enquanto o repórter-personagem pondera se deve ir ao local indicado pela recepcionista, um taxista se aproxima e demonstra ter a mesma opinião que a moça: aquele homem, vestido daquela forma, com aparência de garimpeiro, deveria ir à pensão de dona 
Leontina. Percebemos, assim, que a caracterização do repórter o fez ser identificado enquanto uma nova personagem para o garimpo.

Uma das primeiras imagens a chocar o repórter, futuro garimpeiro, é o carro utilizado pelo taxista: um Opala ${ }^{46} 1971$. Um dos primeiros modelos a ser produzido no Brasil, o Opala foi lançado em 1968. Além de novo, aquele carro também simboliza o montante de dinheiro que circula no ambiente do garimpo. Os garimpeiros lidam com a busca incessante pelas pedras durante meses, anos, mas aqueles que circundam as comunidades também são influenciados pela circulação de recursos.

Figura 27 - 30 dias na ilusão do garimpo, Revista Realidade, nº 65, ago. 1971, p. 32-33

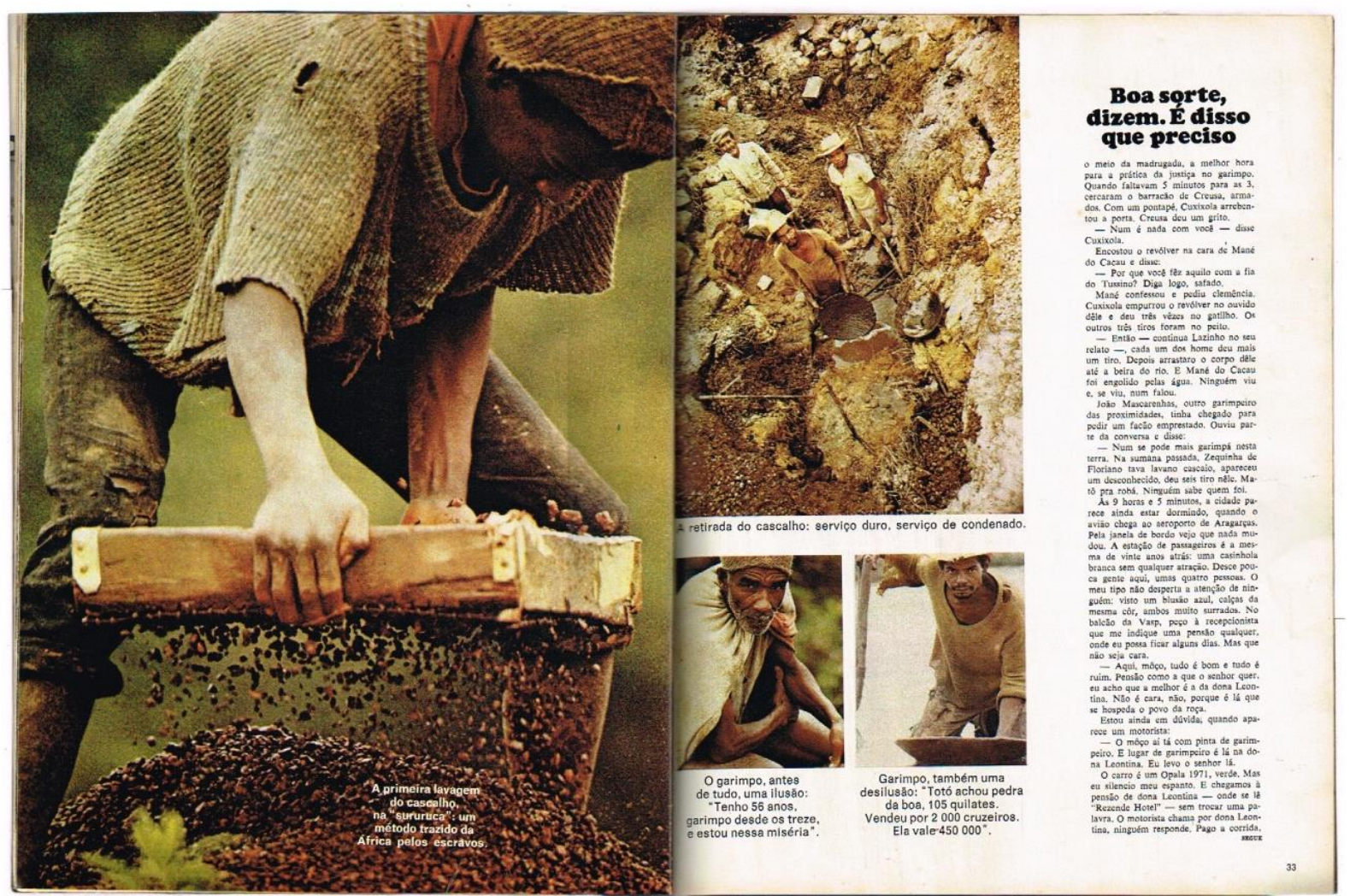

Fonte: Acervo do Grupo de Pesquisa Estudos Fotográficos (CNPq/UFCA)

Outro fato que impressiona a personagem-narrador da história é o silêncio que envolve algumas das outras personagens. Este é o caso do motorista do taxi, que não fala com ele em momento algum, e da “[...] cabocla de nádegas salientes e seios altaneiros [...]" (LEAL, 1971, p. 34) que o leva a um quarto da pensão, sem ao menos pedir documentos. Mais de uma vez o

\footnotetext{
${ }^{46}$ Lembramos que o modelo de carro Opala é citado nesta reportagem e em $O$ Canavial esmaga o homem, estando lá representando o dono do engenho.
} 
narrador vai se referir a mulheres mais novas como 'caboclas'. O termo 'caboclo' tanto pode se referir ao tom de pela daquelas mulheres, acobreado, como a uma característica da personalidade delas: desconfiadas e traiçoeiras.

Paralelo ao primeiro contato do repórter-personagem com os moradores de Aragarças há a disposição de retratos coloridos de garimpeiros (Figura 27), todos trabalhando. Em contraposição aos trabalhadores presentes nas páginas anteriores, que posam juntamente com elementos do garimpo, tais como peneiras e sacos. Nesta página podemos fazer a leitura de quatro fotografias. Duas delas, menores em relação às outras, nos apresentam duas possibilidades de garimpeiro: um mais velho, com barba branca e aparentando cansaço, e outro mais novo, trabalhando dentro do rio. Há ainda uma de tamanho intermediário, onde três homens estão arranjados, parados, e uma fotografia ocupando uma página inteira, onde um garimpeiro trabalha na primeira das lavagens do cascalho.

Com um caráter de reconstituição histórica, a legenda da primeira fotografia, aponta para a origem do método de trabalho dos garimpeiros do interior do estado do Goiás: ele é africano e foi trazido para o Brasil pelos escravos. Não sofreu grandes modificações com o passar dos anos. A fotografia, em tom amarronzado, não nos deixa perceber o semblante do homem. Ela deve ter sido realizada no início da manhã, período ainda frio do dia, posto que o homem utilize duas blusas. Um chapéu de tecido e uma calça completam a indumentária. A fotografia congela o momento no qual o cascalho passa pela primeira das lavagens. A peneira possui uma nomenclatura específica: sururuca.

Inclinado para frente, esta personagem parece abaixar a cabeça para a situação que vivencia. Uma vez que esta é a única posição na qual pode estar para procurar as pedras e o faz durante todo o dia, o homem dedica toda a sua atenção ao ato de lavar e peneirar o cascalho. O trabalho também não deixa espaço para o ócio, de forma que tal posição, como podemos ver repetida em mais imagens da página e da reportagem, revela uma personagem atenta ao trabalho e que, ao mesmo tempo, não tem forças para enfrentar a vida e os problemas que ali existem.

Ao lado do homem trabalhando na primeira peneira, podemos observar um grupo que paralisou o trabalho a fim de direcionar o olhar para a parte superior do local. Fotografias tomadas de um ângulo superior ao retratado transmitem a sensação de que o leitor, o observador, tem domínio sobre as personagens. Elas estão submissas ao poder daquele que retrata, daquele que lê. A imagem dispõe, no espaço do garimpo, pessoas das mais diferentes 
idades: nesta fotografia podemos observar um jovem, um adulto jovem e um adulto mais velho.

O tom amarronzado, ligado ao barro que toma o espaço, impregna toda a imagem. As pedras, a terra, a água, os instrumentos de trabalho, as roupas e até mesmo a pele das personagens compartilham uma variação cromática reduzida. As expressões dos homens apontam para o cansaço, a tristeza e, sobretudo, são dotados de uma seriedade que colore com cores duras a paisagem. A frieza dos homens se mistura com a névoa de medo que persegue os garimpeiros, jovens ou velhos. A tensão do lugar pode ser apreendida a partir da observação dos semblantes destes homens. Como a própria legenda da fotografia destaca, a retirada do cascalho é um trabalho de condenados. Estão presos ao garimpo, às redes que se formam em torno dos trabalhadores e de suas relações interpessoais.

As duas próximas fotografias são retratos de dois garimpeiros. O que diferencia estas imagens das demais, podemos destacar, é a presença de legendas que estão intimamente ligadas ao texto escrito, não necessariamente ao texto iconográfico. A primeira delas tem como legenda a seguinte afirmação: "O garimpo, antes de tudo, uma ilusão: 'Tenho 56 anos, garimpo desde os treze, e estou nessa miséria"” (LEAL, 1971, p. 33). O texto da legenda não aponta um nome para a personagem da fotografia. Porém, mais a frente, na página 38, atribui esta fala a Artur, de forma que podemos apreender que esta é uma característica daquele grupo: os homens vão ao garimpo com a intenção de mudar de vida, não encontram as pedras que almejam, mas continuam ali até que se acabem os dias, acreditando que sairão da miséria, mas mesmo assim vivendo nela e não tendo oportunidades de sair.

O segundo retrato traz a seguinte legenda: "Garimpo, também uma desilusão: 'Totó achou pedra da boa, 105 quilates. Vendeu por 2000 cruzeiros. Ela vale 450 000'” (LEAL, 1971, p. 33). Mais uma vez, a legenda não faz referência direta ao homem representado na fotografia. O garimpeiro desta imagem faz parte da composição da imagem acima. Ele carrega, em ambas as fotografias, o mesmo objeto. Mergulhado até a altura dos joelhos no rio, o homem segura uma das peneiras com uma mão e se apoia, por meio de uma espécie de muleta, com a outra mão. O olhar fixo no fotógrafo demonstra atenção e mesmo serenidade. Em resumo, a expressão da personagem é de resignação. A roupa suja, os braços cobertos por lama seca e todas as peças de roupa rasgadas apontam para algumas das características do trabalho. Os homens mergulham no garimpo, buscam incessantemente as pedras preciosas e mantêm o olhar atento, necessário à busca. 
Em contrapartida, a legenda da fotografia desvenda uma das facetas da ilusão do garimpo. Para além da dificuldade em encontrar as pedras, há também a dificuldade para vendê-las. Os garimpeiros precisam negociar com aqueles que estão nas imediações do garimpo e que, por consequência, não oferecem o valor real da mercadoria. No caso apontado no texto, o diamante foi vendido por um preço pífio, quando poderia ter mudado a vida daquele homem para sempre. No entanto, na página 38, a narrativa nos mostrará quais as consequências da existência de tal diamante, de sua venda. $\mathrm{O}$ medo e a violência perduram ao redor do garimpo.

Avançando na leitura do texto, o próximo intertítulo é o prenúncio de mais uma morte no garimpo: será a quarta da narrativa, porém a primeira, cronologicamente, à qual o novo garimpeiro terá acesso: "Nenzinha deu à luz e matou a criança" (LEAL, 1971, p. 34). O texto, assim anunciado, gera expectativa no leitor. Quais as circunstâncias do crime? Por que ela matou a criança? Como a morte chegou ao conhecimento dos garimpeiros? Qual o impacto de tal relato junto ao repórter? Todos esses questionamentos podem aflorar a partir do intertítulo anteriormente citado.

Em se tratando do ambiente do garimpo, o repórter sai, logo no primeiro dia, em busca de sentir o que caracteriza o ambiente do lugar. Após deixar seus pertences no quarto, desce para o primeiro pavimento da pousada e encontra a já famosa Dona Leontina. A mulher é descrita como alguém de olhos vivos, ou seja, de pulso forte, e autoritária. Aquela senhora dirige a pousada aos gritos, dando comandos aos empregados. Em ambientes como estes, as mulheres veem a necessidade de, socialmente, se imporem por meio da força. Dona Leontina não faz introduções, pergunta diretamente o que quer saber. Sonda o novo hóspede em busca de informações sobre o passado ou o presente daquele. A curiosidade pelo futuro garimpeiro é latente.

A construção da personagem realizada por José Leal passa por uma adaptação às características físicas e psicológicas daqueles que são considerados garimpeiros em potencial. Quando questionado por Dona Leontina sobre suas atividades, o homem dá prosseguimento ao seguinte diálogo:

- O senhor é viajante? Qual o laboratório?

- Não, senhora, eu mexo com minérios. Vim me meter com garimpo por aqui. Me disseram que as coisas estão boas...

Dona Leontina me olha da cabeça aos pés. Talvez desconfiada. E me diz:

- Se o senhor mexe com garimpo, vá conversar com Lió. Conhece ele?

- Não, estou chegando agora. (LEAL, 1971, p. 34, grifo nosso). 
A primeira impressão da mulher é de que aquele é um homem com um maior grau de instrução, pertencente a outro grupo de trabalhadores do garimpo: aqueles que trabalham para a indústria, viajam de um garimpo a outro em busca de material. Percebendo a leitura feira pela dona da pensão, o repórter-personagem utiliza um linguajar que julga mais próximo daquele dos garimpeiros para informar que está ali pelo garimpo. A utilização dos verbos mexer e meter-se, em substituição a trabalhar, são indícios da apropriação que a personagem faz do vocabulário do meio.

Como a mulher é curiosa e lida diariamente com novos garimpeiros e pessoas interessadas no garimpo, o repórter-personagem percebe certa desconfiança em relação à personagem que está representanda. A desconfiança é traduzida, na fala da personagem, pelo seguinte fragmento: 'Se o senhor mexe com garimpo [...]'. Dona Leontina não tem certeza do que ele diz e explicita tal dúvida por meio da fala.

Segundo Dona Leontina, o melhor dia para encontrar com garimpeiros na cidade seria o sábado, dia de realizar as compras da semana. No entanto, aquela é uma quinta-feira. O texto não tem a preocupação em marcar temporalmente os eventos narrados. Porém, em algumas passagens, podemos identificar alguns dêiticos. Desta forma, o repórter-garimpeiro chega à cidade durante a semana e vai em busca de contatos e, especialmente, de sentir o clima do ambiente.

A segunda parada, após a pousada, é o armazém do Lió, conforme indicado por Dona Leontina. O narrador do texto define o comerciante como um sujeito caboclo, simpático e cuja testa é queimada pelo sol. Reflexo do trabalho no cerrado, o homem aqui apresentado produz uma imagem mental que condiz com aquela que pudemos observar nas fotografias anteriores. O homem daquela região tem a cor do barro que abriga os garimpos. Ele compartilha com o garimpo mais que o espaço, mas também características visuais.

Ao dar início à conversa com o comerciante, o futuro garimpeiro é confrontado com as duas possibilidades de trabalho no garimpo:

- O senhor que financiar, como patrão, ou vai dar duro?

- Depende, seu Lió. Depende do que for melhor. Tenho um dinheirinho...

- Eu acho melhor o senhor financiar. Aí não precisa entrar no batente, fica por aqui mesmo só esperando o resultado do trabalho dos garimpeiros (LEAL, 1971, p. 34, grifo nosso).

A própria personagem elege o que acredita ser a melhor opção de trabalho no garimpo: aquela que não exige ir, de fato, ao espaço do garimpo. Ser o detentor dos recursos financeiros 
e explorar a mão de obra daqueles mais pobres seria, na visão de Lió, a melhor opção para trabalhar naquela região. Como forma de demonstrar a preocupação que existe entre os indivíduos pertencentes àquele grupo, o comerciante comenta com o novo garimpeiro sobre a existência de outro, Artur, que estaria em dificuldades.

A forma como o jornalista vai construindo a sua personagem, perante os moradores da localidade, também ganha novos contornos nesta passagem: o respeito aos mais velhos, acanhado, uma característica de resignação. Para o novo garimpeiro, o que aquele homem disser, seguramente, será a melhor opção. Além disso, o fato de não terminar a frase, deixá-la em suspenso, também denota certa insegurança por parte da personagem. Estas características contrastam com a segurança, ao falar, de Lió.

Estando no ambiente do armazém, surge uma nova informação acerca da vida no garimpo: os elementos essenciais ao sustento do garimpeiro durante a semana. Ao 'fazer o saco', como descreve o texto, eles compram farinha, feijão, açúcar, sal, café e banha. Apesar de ser quinta-feira, e o dia de compras ser o sábado, o novo garimpeiro recebe a notícia de que poderá encontrar Artur naquele dia, uma vez que o mesmo teve de voltar do garimpo em busca de banha, que teria acabado. A transcrição do pensamento do repórter naquele momento aponta para a estratégia utilizada pelo mesmo a fim de ser aceito pelo grupo: "Resolvo esperar ali mesmo, pois há uma meia dúzia de garimpeiros no armazém de Lió, conversando, e eu preciso fazer amizade com a turma" (LEAL, 1971, p. 34).

\subsection{A narrativa da morte e seus efeitos sobre o repórter-personagem}

A conversa, reproduzida na narrativa, será aquela pré-anunciada no intertítulo. Nenzinha, a mãe de poucos anos, mata friamente o filho:

- Já soube da última, Lió? Nenzinha tava prenha, pariu e matou o filho.

Os homens se interessam pela novidade. O garimpeiro, que se chama Joaquim, conta com detalhes:

- Foi a Nenzinha, Lió. Tava buchada de nove meses e conseguiu esconder a situação da mãe, não se sabe como. Pariu sozinha, depois matou a criança, enfiando um prego na moleira dela. Aí cavou um buraco perto do hotel, lá na Barra Cuiabana, e enterrou o anjinho (LEAL, 1971, p. 34).

O interesse do grupo é atraído pela narrativa da violência. Os homens interagem, delegam atenção ao assunto, por ser um evento que, apesar de compor a narrativa do medo e 
da violência no garimpo, faz-se diferente: neste caso, uma mãe, ser que deveria cuidar dos filhos, vai contra a imagem pré-estabelecida e mata o recém-nascido.

$\mathrm{O}$ crime não teria sido descoberto, caso o parto realizado pela própria garota não tivesse tido consequências. Levada ao hospital pela mãe, a menina confessa o crime. Ao desenterrarem o corpo, descobrem que era uma menina. Seria mais uma menina sem muitas possibilidades de vida naquela localidade. A narrativa local aponta para destinos semelhantes entre serem do mesmo sexo: os meninos entram para o garimpo ainda crianças e buscam até o fim dos dias a riqueza em forma de pedra; as meninas serão violentadas, obrigadas a se prostituírem ou serão as responsáveis por cozinhar para os garimpeiros, ao irem viver juntamente com um deles.

De todos aqueles que escutam a narrativa, Lió é o único a se posicionar: “- Isso é coisa de doido, meu Deus [...]” (LEAL, 1971, p. 34). Seguido à afirmação, outro garimpeiro dá início ao relato de mais um crime no garimpo. Os narradores da violência parecem disputar entre si qual detém a novidade mais cruel, aquela que mais vai surpreender os demais garimpeiros. Acostumados a crimes bárbaros, a notícia tem de trazer elementos novos e chocantes para que aquele que conta a história tenha para si a atenção dos ouvintes.

Nonô relata o quinto evento, transcrito na reportagem, que culmina em mortes no ambiente do garimpo. A narrativa do garimpeiro vai desde um momento anterior ao início da trama, passando pela aproximação do assassino e culminando com o ato:

- Lá no Garimpo do Deixado, três caboclos estavam garimpando com a graça de Deus. Apareceu outro, dizendo que era bom na catação de pedra, e começou a trabalhar. Betinho, Genê e Ninito notaram que o cabra queria era moleza, queria comer às custas deles. Ficaram quietos. Mas o cabra percebeu que estava sendo notado: de noite, entrou na barraca, onde os três estavam dormindo. Deu nove facadas em Betinho, cinco em Ninito. Genê fugiu apavorado. E o assassino sumiu (LEAL, 1971, p. 34).

A fala de Nonô estabelece o local no qual se deu o acontecimento (Garimpo do Deixado) e as personagens que farão parte da narrativa. No entanto, apenas os três amigos possuem nomes. O sujeito que não integra o grupo dos garimpeiros, que não é aceito pelos demais enquanto tal, é chamado apenas de 'cabra'. Os garimpeiros, sujeitos dotados de bondade, percebem que estão sendo explorados, mas não reclamam. O outro, não sendo, essencialmente, um garimpeiro, ao perceber que descobriram sua tramoia, tenta tirar a vida dos três amigos. 
A reação do homem aponta para o ato de tentar encobrir uma trapaça. Não sendo garimpeiro e, caso a estória se espalhasse, não tendo aceitação no grupo, tenta silenciar as testemunhas de seu mau caráter. $\mathrm{O}$ assassino foge sem concluir o seu objetivo, porém também sem ter seu nome revelado. O homem fica escondido sob a aura do crime cometido contra aqueles que trabalhavam sem fazer mal a ninguém.

A frieza dos crimes começa a atormentar a mente do repórter-personagem. Na medida em que escuta os relatos e percebe que o garimpeiro que espera, Artur, não aparece, o medo e o pânico começam a assumir um papel importante para o jornalista. Como ele não tem a relação de pertencimento do lugar, bem como não adquiriu o sentimento de neutralidade frente à narrativa da violência, o corpo da personagem começa a expressar os sentimentos em relação ao clima: "Começo a ficar impaciente. Tenho um nó perto da garganta e uma inquietação nas mãos. Tradução disso tudo: estou com um pouco de medo. Mas prefiro imaginar que a comida da dona Leontina me fez mal, e peço a Lió um sonrisal e um copo de água" (LEAL, 1971, p. 34).

Como uma forma de autodefesa junto ao grupo, o repórter, ao criar a personagem, formula os próprios pensamentos de forma que se torne, minimamente, parecido com os garimpeiros. Ao imaginar a reação de um garimpeiro, reformula os próprios pensamentos e sentimentos, visando entender a forma como os homens daquela região pensam e sentem: nega os pensamentos do jornalista e assume os pensamentos da personagem.

Apresentado enquanto um 'curau' ${ }^{47}$, garimpeiro novato no ramo, escuta a frase de batismo dos garimpeiros: “- Deus te ajude, curau. E a nóis tamém” (LEAL, 1971, p. 34). O pronunciamento deste código substitui as perguntas quanto à origem do homem. Aqueles são sujeitos sem passado. Pouco se sabe sobre o que houve antes de eles chegarem ao garimpo. No entanto, a primeira frase dita a um garimpeiro dá mostras acerca do imaginário deles mesmos acerca do ambiente: é preciso proteção divina para que possam trabalhar em paz, não sejam mortos em função da violência característica do ambiente.

O código que os garimpeiros compartilham não permite que eles questionem sobre o passado dos novos integrantes do grupo, mas a curiosidade pode ser sentida pelo repórtergarimpeiro. Sendo assim, pressionado pelo contexto, o homem relata as origens de sua personagem:

\footnotetext{
${ }^{47}$ Segundo o Dicionário Michaelis de Português, curau significa, pejorativamente, caipira, matuto, tabaréu.
} 
Percebo que eles estão curiosos. Então resolvo dar uma explicação ao grupo que se forma em meu redor:

- Querem sabê? Pois eu vim da Paraíba. Andei pelo Rio de Janeiro, e como num havia jeito de arranjá minha vida, peguei o que tinha e parti para cá. Andei fazendo umas coisas que o povo num gosta... (LEAL, 1971, p. 34)

As informações foram pensadas anteriormente. O repórter sabe qual a origem da personagem criada por ele. Ao narrar para os demais, abre espaço para certa identificação do grupo para com ele. Um sujeito nordestino, que foi para o sul, mas fez algo ilegal e tem de fugir, indo para o centro-oeste. Uma estória comum, natural para aquele ambiente. Assim, a personagem compartilha com os garimpeiros de um passado não totalmente revelado, porém semelhante.

Nesta reportagem as legendas das fotografias antecipam passagens do texto. A fotografia presente na página 34 (Figura 28), por exemplo, antecipa o estado físico do repórter após dar início ao trabalho no garimpo: “A última peneirada. É aqui que pode surgir o diamante. 'Com três dias de garimpo, meu rosto, braços e mãos estavam inchados, os dedos começaram a rachar, o mundo ficando distante"” (LEAL, 1971, p. 34). Neste trecho, a personagem que narra, em primeira pessoa, é o próprio repórter. Estando separado do bloco de texto, em uma legenda, o autor se permite dar a própria leitura acerca da situação. $\mathrm{O}$ mundo fica distante conforme se convive com as preocupações e problemas do garimpo.

A legenda mescla a informação sobre a imagem, um homem manejando a peneira dentro do rio, cujo olhar está fixo no fotógrafo, com a experiência do repórter no local. Não temos como afirmar que o homem representado na fotografia seja José Leal, mas a atividade desenvolvida durante a tomada da imagem é aquela à qual ele se dedica durante o tempo que passa no garimpo.

Como podemos observar na Figura 28, o título de página faz referência à exploração e ao grau de incerteza que envolve a vida dos garimpeiros: Artur, trabalhando no garimpo há 43 anos, continua na miséria. Primeiramente, destacamos a utilização do termo miséria. Conforme utilizado neste contexto, ele faz referência a um espaço: o garimpo é a representação da miséria. Assim como o homem mora, vive, no garimpo, também o faz em relação à miséria. Convive diariamente com ela.

Para além do ambiente, o resgate da estória comum aos garimpeiros faz perceber que, ao contrário do que se imagina acerca daqueles que lidam diretamente com a riqueza, mesmo uma vida inteiramente dedicada àquele labor pode não ser o suficiente para mudar a vida dos miseráveis que para aqueles locais se dirigem. Artur, assim, pode ser tomado como um nome 
genérico, uma vez que não possui sobrenome, representando o homem do garimpo, aquele sujeito que vive em função da busca pela mudança de vida a partir da sorte, mesclada ao trabalho árduo.

Figura 28 - 30 dias na ilusão do garimpo, Revista Realidade, nº 65, ago. 1971, p. 34-35

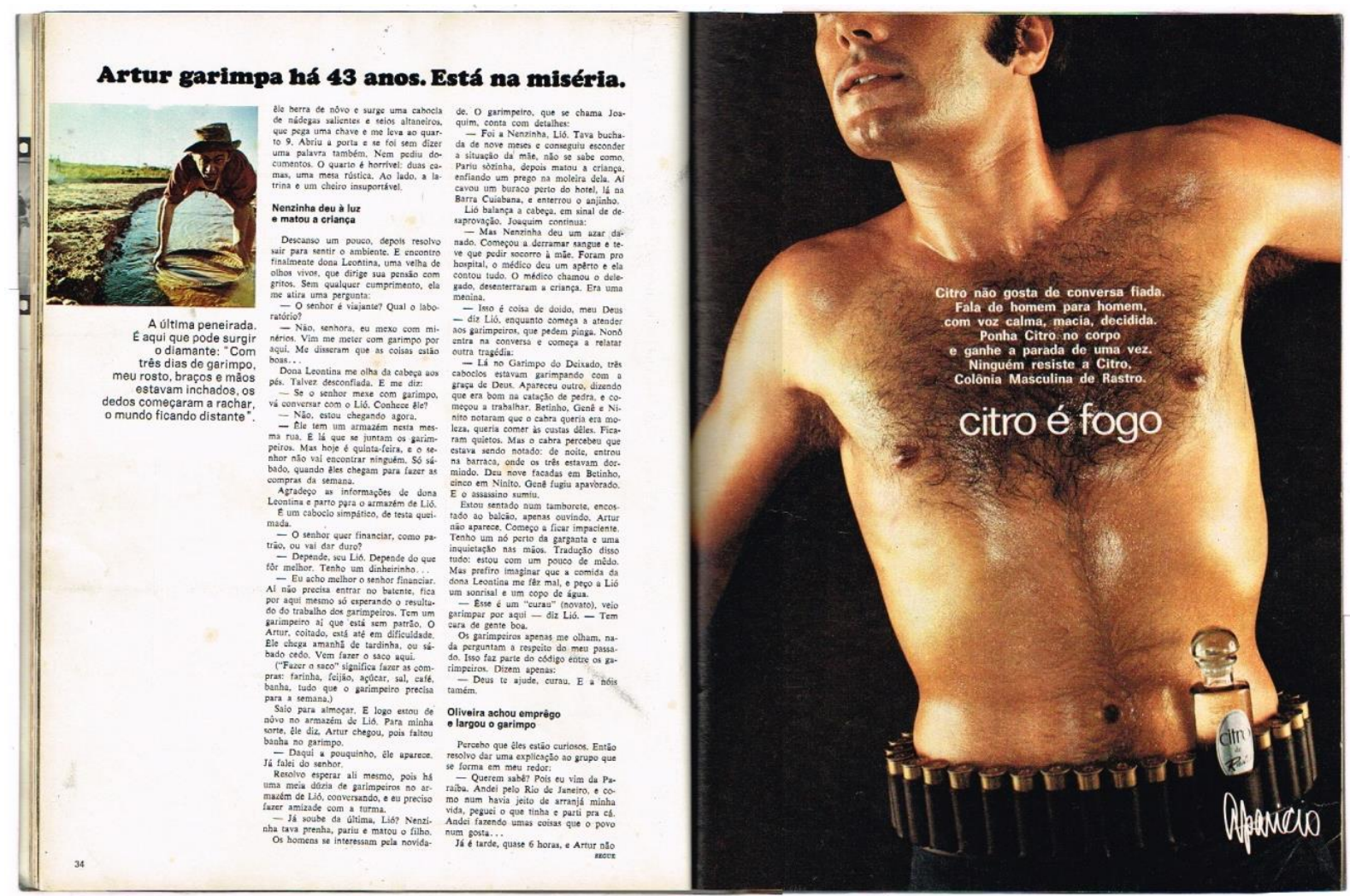

Fonte: Acervo do Grupo de Pesquisa Estudos Fotográficos (CNPq/UFCA)

A saída do garimpo só é possível quando aqueles sujeitos são chamados a trabalharem em outras atividades. Este é o caso de Oliveira, o ex-patrão de Artur. Tendo em vista que o garimpeiro em dificuldades não se fez aparecer no armazém de Lió, este indicou ao repórterpersonagem que fosse em busca de Oliveira, visando obter informações acerca do garimpo e do sujeito em questão. Oliveira relata:

- Parei com o garimpo porque não posso me meter com negócios, ocupando um cargo público. E também porque me casei há pouco tempo. Mas o garimpo é meu, e lá só entra quem eu quiser. Se o senhor quiser explorar, eu deixo, pois é melhor do que ficar parado. Vocês me dão $25 \%$ da renda líquida (LEAL, 1971, p. 36, grifo nosso). 
Como podemos observar, a saída do garimpo por parte de Oliveira não é completa. O espaço do garimpo continua pertencendo a ele e os homens devem pagar para explorar. A saída, parcial, dá-se graças ao envolvimento do mesmo com a política e com a formação de uma família. Pode-se dizer que o ambiente leva o ex-garimpeiro a manter parte dos laços que o ligavam ao garimpo. A principal forma de fazê-lo é mantendo parte do domínio sobre os garimpeiros: detém o espaço, decide quem pode trabalhar ali e cobra de tais pessoas uma taxa percentual sobre o valor dos diamantes encontrados.

A passagem entre a cidade e o garimpo na narrativa dá-se de forma acelerada. A transição acontece ao descrever a segunda viagem em taxi na qual o repórter-personagem embarca: o garimpeiro em potencial e Oliveira entram em um DKW barulhento e percorrem os sete quilômetros que separam a cidade do garimpo, localizado em meio ao cerrado (LEAL, 1971, p. 36). Lá, o repórter-personagem é, formalmente, apresentado a Artur:

Caminhamos até a beira do riacho, onde encontro Artur. Oliveira começa a conversar e me apresenta aos futuros companheiros. Artur é um caboclo baixo, olhos miúdos, baiano de Barreiras, que fala como se estivesse murmurando. A mulher de Artur, dona Clotilde, conhecida por Coló, parece até mais velha que ele, tem os olhos tristes, os cabelos embranquecidos, e fala olhando para o chão. Taveira, José Gomes Taveira, maranhense de São Raimundo das Mangabeiras, é o outro (LEAL, 1971, p. 36, grifo nosso).

Duas características consideradas importantes pelo narrador, a fim de construir linguisticamente as personagens do garimpo, são os olhos e o modo de falar. Desta forma, os olhos tristes de Coló expressam a situação da mesma, sem que ela tenha que se declarar triste. Se o olhar demostra tristeza, o acompanha durante todo o percurso. No entanto, a timidez e a expressão de diminuição frente ao patrão, detentor de poder, faz com que a tristeza se esconda a partir do ato de baixar a cabeça.

Nenhum dos dois, Artur ou Coló, possui segurança ao falar. Na medida em que Coló baixa a cabeça e fala olhando para o chão, Artur fala muito baixo, murmurando: ele fala sem querer ser escutado. Há nesta ação reflexos do medo, da insegurança e da timidez. O fato de ser baixo e ter olhos pequenos também pode ser tomado como um reflexo do ato de se diminuir perante o grupo. Lembremos, ainda, que essas personagens não possuem sobrenome. Congregam as características da maior parte dos garimpeiros da região que formam família.

Taveira relata, para Oliveira, que encontrou um diamante: levou um ano de busca até encontrar a pedra, que tem a proporção da cabeça de um alfinete. Além da dificuldade do próprio labor, ainda há problemas com as características ambientais do cerrado. $\mathrm{O}$ forte calor 
é seguido pela presença de mosquitos. Os homens que vivem naquela condição estão acostumados a lidar com este tipo de inconveniente por meio de uma receita local: queimam esterco de gado e a fumaça afugenta os mosquitos. Artur, naquela ocasião, é o responsável por realizar a ação.

O próximo passo de reconhecimento do local envolve as acomodações nas quais o repórter-garimpeiro ficará. Uma barraca, com cerca de três metros por dois, contendo poucos móveis e uma rede, é descrita por Artur como sendo aquilo no qual eles podem 'se ajeitar'. A personagem de Artur é arquitetada como aquela responsável por mediar as novas descobertas do repórter-personagem. Além de explicar como lidar com os mosquitos e alertá-lo de que é possível viver em local tão pequeno, Artur explica como é a relação do garimpeiro novato (curau) com o garimpo: “- Garimpo não tem ciência. Como o companheiro num tá acostumado, pode começar pela 'escrita' (catando pedrinhas, depois da peneirada). Diamante num engana ninguém, nem o companheiro vai-se enganar. Quando tivé desconfiança, me chama" (LEAL, 1971, p. 36). A fotografia presente nesta página (Figura 29) dialoga com a fala de Artur. Nela, impressa em preto e branco, dois homens trabalham na escrita.

Figura 29 - 30 dias na ilusão do garimpo, Revista Realidade, no 65, ago. 1971, p. 36-37

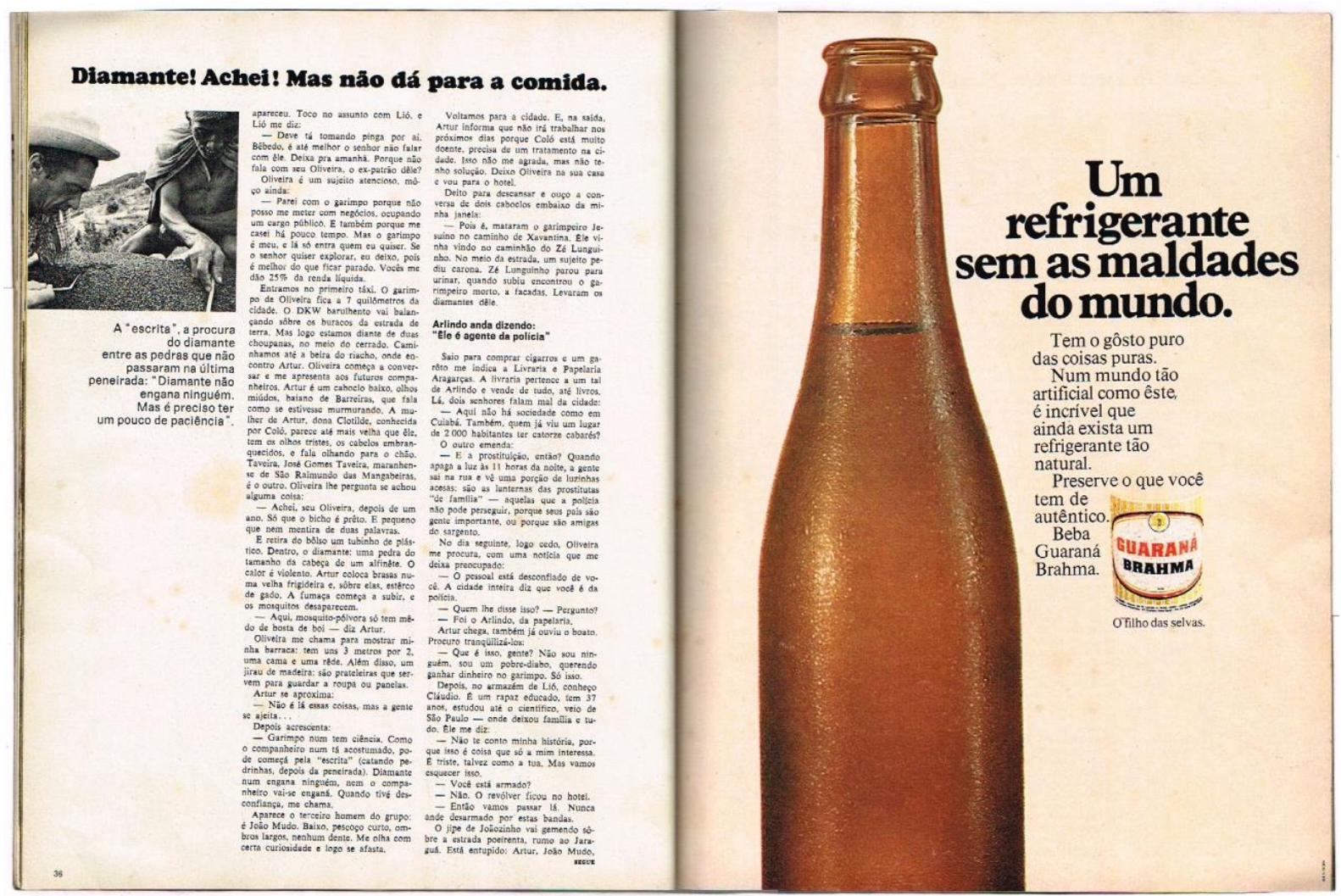

Fonte: Acervo do Grupo de Pesquisa Estudos Fotográficos (CNPq/UFCA) 
Assim, o garimpo é tido como algo instintivo, que não necessita de um conhecimento específico. Estando disposto a garimpar, qualquer homem pode aprender e, com sorte, encontrar diamante. A relação de companheirismo, também instintiva, une aqueles homens. As personagens identificam-se enquanto companheiras e se colocam à disposição para ajudar os que não sabem.

Ao encontrar o último homem do grupo, João Mudo, o repórter-personagem identifica, mais uma vez, informações vindas do elemento 'olhar'. A leitura do olhar daquela personagem descreve certa curiosidade, ao passo que a personagem em si se afasta do grupo ao ser percebida, descrevendo um ato de timidez ou vergonha.

Apesar da disponibilidade de Artur, o mesmo avisa que não ficará no garimpo nos primeiros dias de atividade do novo garimpeiro. Coló está doente e precisará ficar na cidade. O repórter-garimpeiro também volta à cidade, a fim de recuperar seus pertences na pousada. O desconforto do narrador em relação a ter de labutar sem Artur está expresso.

A narrativa da violência ganha mais um capítulo após a volta do repórter-personagem para o hotel. Tentando descansar após a viagem ao garimpo, ele ouve dois anônimos conversando na rua:

- Pois é, mataram o garimpeiro Jesuíno no caminho de Xavantina. Ele vinha vindo no caminhão do Zé Lunguinho. No meio da estrada, um sujeito pediu carona. Zé Lunguinho parou para urinar, quando subiu encontrou o garimpeiro morto, a facadas. Levaram os diamantes dele (LEAL, 1971, p. 36).

A imagem dos garimpeiros enquanto grupo tem reflexos na forma como os próprios garimpeiros constroem as narrativas de si. A vítima é 'o garimpeiro', o criminoso é 'um sujeito'. Sujeito este que não possui nome, não faz parte do grupo, não é conhecido dos demais companheiros. O suspense em torno do acontecimento descreve o desconhecido como aquilo que os homens devem temer; descreve também a desconfiança que eles devem nutrir em relação àqueles que chegam ao grupo.

O repórter-personagem também foi alvo da desconfiança dos garimpeiros. Chegando e não causando uma identificação integral, foi imaginado enquanto um policial. Como o perigo e o medo são elementos indissociáveis daquela cultura, os homens dão início a um processo de busca por uma explicação que será, em geral, a pior para eles. Em outras palavras, são pessimistas e desconfiados. 
Em um local pequeno como Aragarças, as especulações acerca da vida dos moradores são intensas. Ao entrar em uma livraria, por exemplo, o repórter-personagem se depara com a seguinte discussão:

- Aqui não há sociedade como em Cuiabá. Também, quem já viu um lugar de 2000 habitantes ter catorze cabarés?

O outro emenda:

- E a prostituição, então? Quando apaga a luz às 11 horas da noite, a gente sai na rua e vê uma porção de luzinhas acesas: são as lanternas das prostitutas "de família" - aquelas que a polícia não pode perseguir, porque seus pais são gente importante, ou porque são amigas do sargento (LEAL, 1971, p. 36).

Assim, percebemos a relação que existe entre a prostituição e a polícia: quando é do interesse da força policial, os crimes não são vistos. E a população defende a perseguição às prostitutas, bem como condena a existência dos cabarés. Para aqueles homens da livraria, a relação dos garimpeiros com o sexo é algo que retrata o atraso da população. A vida em sociedade estaria, portanto, desvencilhada da relação com o sexo e, também, com a violência.

Precisamente após presenciar essa discussão, que engloba os pudores, medos e preconceitos dos habitantes, o repórter-personagem é informado de que a cidade inteira estaria comentando que ele seria ligado à polícia. $\mathrm{O}$ foco da fofoca vem da papelaria, por onde ele passou no dia anterior para comprar cigarros. Dois dos companheiros do repórter-garimpeiro já haviam ouvido o boato, Artur e Oliveira. A fim de defender-se, o alvo das fofocas explica: “- Que é isso, gente? Não sou ninguém, sou um pobre-diábo, querendo ganhar dinheiro no garimpo. Só isso" (LEAL, 1971, p. 36).

A fala, utilizada como forma de defesa, contribui para a construção da personagem do repórter. Ele se define como um pobre-diábo, numa referência a alguém sem posses, sem família e sem passado. Delimita sua busca em torno do dinheiro e resume sua personagem nestes dois termos.

A busca pelo conhecimento do ambiente por parte do repórter-personagem passa por um novo momento no armazém de Lió, no qual ele conhece Cláudio. Diferente dos demais garimpeiros, a nova personagem estudou, tem 37 anos e é originária de São Paulo. Numa conversa com aquele sujeito, um elemento caracterizador da vida no garimpo se manifesta: os homens devem andar armados, posto que a violência no local possa levar o sujeito a necessitar de autodefesa a qualquer momento. 
Sobre o motivo pelo qual os garimpeiros escondem o passado daqueles que ali são iguais a eles, o pronunciamento de Cláudio também lança luz sobre esta opção: “- Não te conto minha história, porque isso é coisa que só a mim interessa. É triste, talvez como a tua. Mas vamos esquecer isso" (LEAL, 1971, p. 36). Embalados pela tristeza, as personagens preferem não comentar, não tornar públicas, as suas histórias. Ao mesmo tempo, parecem evitar pensar nos motivos que os levaram até aquele ponto do país, até aquele ponto da miséria. Na mesma proporção em que não narram suas próprias histórias, acreditam que as dos demais manterão semelhanças com as suas.

Neste momento da narrativa, parece haver um salto no tempo, porém não relatado. Em um momento anterior, Coló havia ido à cidade em busca de tratamento, posto que estava doente. Artur avisa que passaria alguns dias longe do trabalho. No entanto, todos os ocupantes daquele garimpo estão em um mesmo carro, um jipe, indo para o rio Jaraguá. Coló, recuperada, agora passa mal por outro motivo: “[...] bebeu tanto, que está quase inconsciente” (LEAL, 1971, p. 38). No entanto, na transcrição do pensamento do repórter-personagem, feita algumas linhas à frente, o mesmo se encontra ansioso por seu primeiro dia de trabalho no garimpo. Logo, podemos observar que a narrativa possui falhas quanto à marcação temporal.

Frente ao grande número de pessoas que segue dentro do carro, um total de seis personagens, mais o cachorro de Coló, é natural que surjam diálogos. Uma das conversas relatadas é entre Artur e o repórter-garimpeiro. Nela, há a descrição de como se dá a venda das pedras encontradas no garimpo:

- Eram três diamantes pequenos (um amarelo, outro escuro, outro bem claro). Falei com o Tico, ele me ofereceu 90 contos. Fui ao Neco Rêgo, que ofertou 80. Acabei vendendo prum homem de Goiânia, por 120.

Dos 120 cruzeiros que recebeu, Artur terá que dar 60 para o Oliveira, pois as pedras foram extraídas antes de ele me passar o garimpo. Ficará com 60, mas, como já está devendo 70, de comida, não receberá nada (LEAL, 1971, p. 38).

Os homens trabalham exaustivamente em busca das pedras que, após vendidas, não custeiam o mínimo necessário à vida. Como o dono do garimpo fica com a metade do valor da venda dos diamantes, o restante é insuficiente para cobrir as despesas com alimentação. Assim, os garimpeiros estão constantemente endividados e buscam por uma riqueza que, na verdade, não é e nem será deles. 
As personagens chegam ao garimpo e o repórter-personagem busca suas acomodações. Após o contato diurno com o ambiente, logo chega a noite. Acolhido pela escuridão, o medo retorna à narrativa:

A noite no garimpo é quase assustadora. Um silêncio pleno. Dou conta de que estou no meio do mato, atolado na maior escuridão. Não sei se meus companheiros desconfiam de mim. Lá na cidade falaram também que eu era um contrabandista. Aqui, penso, poderia ser morto, enterrado, ou jogado no rio, e ninguém ficaria sabendo: simplesmente diriam que desapareci, que fui embora. Decido que é preciso comprar a simpatia de todos e, na manhã seguinte, quando João Mudo vem me trazer café, dou-lhe uma nota de 10 (LEAL, 1971, p. 38, grifo nosso).

Sendo a narrativa da violência e da morte predominantes em relação a todas as demais naquele ambiente, a personagem cria em sua mente as possibilidades de ser excluída, de forma definitiva, caso não seja aceita pelo grupo. O afastamento geográfico em relação à cidade e mesmo aos outros acampamentos gera insegurança. O silêncio, a falta de ruídos, provoca a sensação de desalento. O silêncio também é uma forma de causar desencontros entre os pensamentos: o repórter-personagem não sabe o que os outros imaginam acerca dele; as demais personagens são silenciadas, pelo narrador, mas podem, ou não, acreditar nos boatos gerados na cidade.

Enquanto o pensamento do repórter-garimpeiro é perturbado por meio das más notícias acerca de seu desenvolvimento no imaginário das demais personagens, mais uma notícia ruim é levada a ele: Taveira, portador de uma voz metálica, portanto, assustadora, conduz a notícia de mais um crime no garimpo:

- Gente, vim trazê notiça ruim. A Joaninha me disse que deu ladrão por aqui essa noite. Mandaram bala nos bandido, eles fugiram. Mas é bão todo mundo aparpá suas coisa, pra mor de vê num farta nada. Outra notiça é que mataram o Maceió, sábado. Quatro tiros no peito, num se sabe quem foi. Esse Jaraguá tá mesmo encrencado (LEAL, 1971, p. 38).

O assassinato de Maceió é o sétimo desta série. A personagem que narra os últimos acontecimentos da região elenca dois fatos envolvendo violência e ajuda, assim, a construir um ambiente voltado para o medo constante. Ao finalizar a narrativa, Taveira sentencia: a situação da região que segue o curso do rio não está boa. Deve-se ter certos cuidados, procurar saber se houve ou não furto, cuidar da própria vida. Mais uma vez, o problema parte 
do desconhecido. Um homem sem identificação, a sombra da violência que permeia o garimpo, é o responsável por tirar a vida de mais um garimpeiro.

Após ouvir a narrativa anterior, o repórter-personagem dá-se duas opções: ou foge do lugar, ou não dá mais importância a esse tipo de fato. Optando, parcialmente, pela segunda opção, vai em busca de sua primeira experiência com o garimpo. Ajudado por Taveira, trabalha na 'escrita'. Na definição daquele garimpeiro, "Quando há diamante, a gente num se engana, brilha mais que tudo" (LEAL, 1971, p. 38).

O repórter-personagem conclui que aquela atividade não será difícil: a maior dificuldade é lidar com os problemas de cunho ambiental, como é o caso da presença dos mosquitos (LEAL, 1871, p. 38). A situação é resolvida por João Mudo, da mesma forma como procedida por Artur em passagem anterior: utilizando-se de esterco de gado queimado.

Em meio às novas experiências do repórter-personagem, eis que surge mais uma notícia de morte no garimpo. Desta vez, por razões naturais. Isabel, que estava grávida, morreu ao tomar banho no rio. A surpresa da personagem reside no modo como a moça foi enterrada, sem qualquer identificação. A justificativa: a polícia não pode desconfiar da existência de um corpo, posto que então daria início a uma série de investigações que poderiam prejudicar os garimpeiros.

Assim como as pessoas que dependem do garimpo não possuem passado, o mesmo acontece com relação à memória delas junto aos demais moradores daquela sociedade. Após a morte, os mesmos não deixam marcas físicas no mundo. Não há um local que represente, socialmente, a passagem pela vida daquele ser. São sujeitos sem passado, vivendo na miséria, sem uma perspectiva de futuro, sem direito à memória.

\subsection{O garimpeiro ganha força: conflito interior entre personagens}

Após três dias de trabalho, a personagem criada pelo repórter começa a tomar forma para o próprio jornalista, de forma que ele começa a sentir como um garimpeiro, a agir como aqueles. A relação entre o personagem e o jornalista toma ares de conflito interior:

Já faz três dias que estou garimpando. As pernas, os braços e o rosto estão inchados de picadas de mosquitos, as mãos estão ásperas, começam a me rachar os dedos. O trabalho na "escrita", aparentemente monótono, é fascinante. De repente, a gente sente uma vontade imensa de encontrar um diamante. Talvez seja essa esperança que mantenha os garimpeiros presos a essa vida miserável. Quando a ansiedade da descoberta do diamante 
começa a me preocupar, Lazinho chega com outra história [...] (LEAL, 1971, p. 38, grifo nosso).

O fascínio que advém da busca pelas pedras preocupa a parcela repórter da personagem. Desvencilhando-se da personagem que ficou na redação de Realidade, o garimpeiro passa a ter mais força sobre o homem que o próprio repórter. A vontade inconsciente de encontrar diamantes supera a confiança que o domina. Vontade e ansiedade, em alguns momentos, ditam reações no repórter-personagem.

Figura 30 - 30 dias na ilusão do garimpo, Revista Realidade, nº 65, ago. 1971, p. 38-39

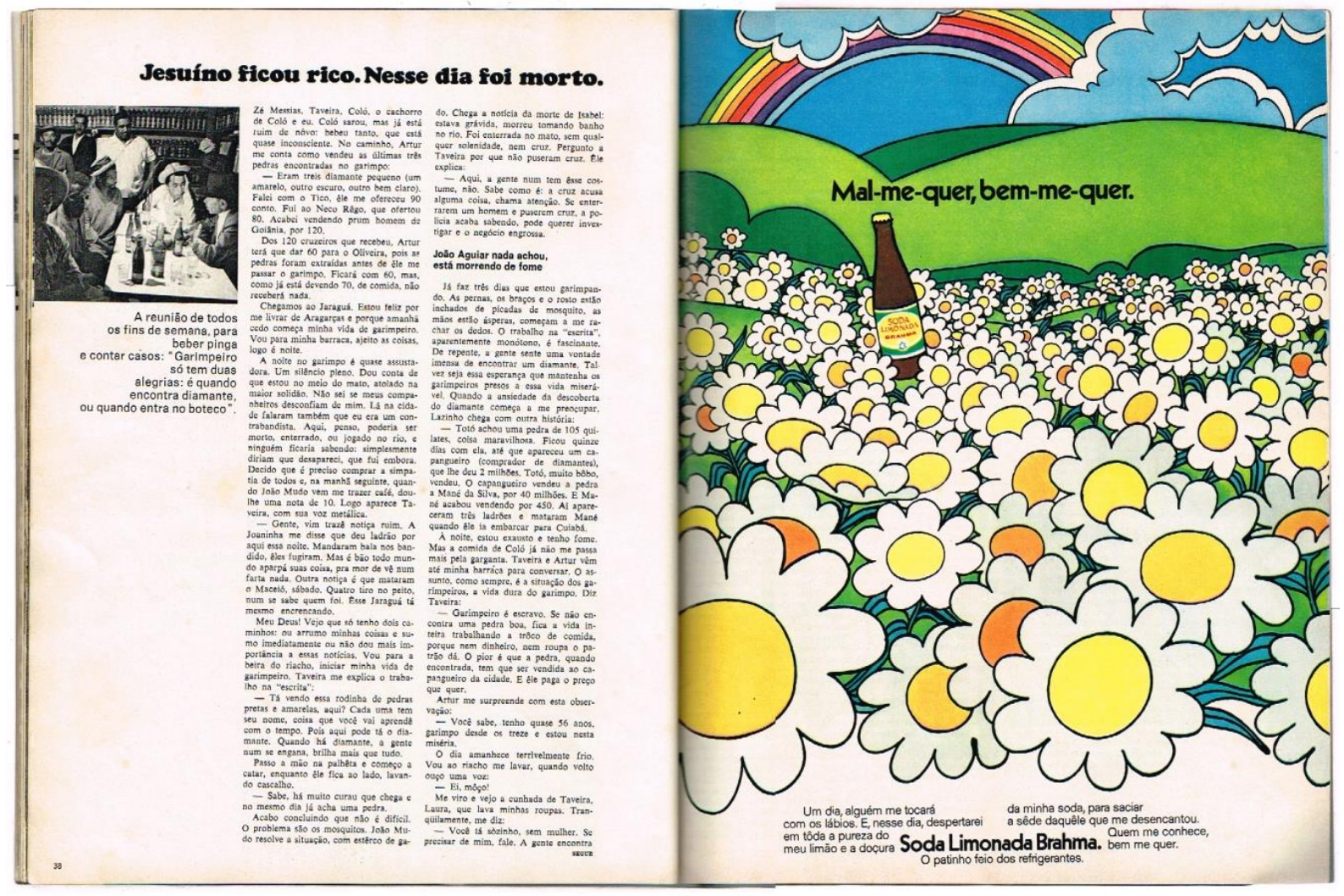

Fonte: Acervo do Grupo de Pesquisa Estudos Fotográficos (CNPq/UFCA)

A história, trazida por Lazinho, descreve a nona morte da narrativa. Um dos garimpeiros daquela região encontrou uma pedra valiosa, mas não a vendeu por duas semanas. Ao conseguir quem lhe oferecesse dois milhões por ela, aceitou. O comprador da pedra a revendeu por 40 milhões. O segundo comprador, por sua vez, revendeu a pedra por 450 milhões: três ladrões o mataram quando partia para Cuiabá. A fuga do garimpo, que se 
daria naquele momento, foi impedida pela violência que vigora no garimpo. O título de página (Figura 30) faz referência a este acontecimento.

A fotografia que compõe a página é completamente independente da narrativa ali disposta. Oito homens se reúnem em uma mesa de bar. Os copos e garrafas estão colocados sobre a mesa de forma desordenada. No segundo plano, estantes repletas de garrafas. Segundo a legenda da fotografia, a felicidade do garimpeiro está associada à bebida e ao ato de encontrar diamantes. Assim como outras personagens aqui analisadas, a bebida costuma ser uma forma de os trabalhadores esquecerem, por alguns instantes, a miséria na qual vivem. Ao mesmo tempo, o álcool costuma dar vasão a ações drásticas naqueles ambientes, como assassinatos e outros tipos de crimes.

Após ganhar a confiança dos garimpeiros, eles revelam ao repórter-garimpeiro a visão que possuem daquela situação social. Taveira declara: “- Garimpeiro é escravo. Se não encontra uma pedra boa, fica a vida inteira trabalhando a troco de comida, porque nem dinheiro, nem roupa o patrão dá. O pior é que a pedra, quando encontrada, tem que ser vendida ao capangueiro da cidade. E ele paga o preço que quer" (LEAL, 1971, p. 38, grifo nosso).

Os garimpeiros, após aderirem ao modo de vida do garimpo, tornam-se escravos da situação. No entanto, o que se destaca é a consciência dos mesmos acerca da situação. Eles percebem o que acontece naquelas relações sociais e de poder, mas continuam pertencendo a elas. A confirmação desta observação vem de uma passagem emitida por Artur: “- Você sabe, tenho quase 56 anos, garimpo desde os treze e estou nesta miséria” (LEAL, 1971, p. 38).

Os acontecimentos, a partir desde ponto da narrativa, sucedem de forma acelerada. $\mathrm{Na}$ manha do dia seguinte, o novo garimpeiro recebe uma proposta por parte da cunhada de Taveira: “- Você tá sozinho, sem mulher. Se precisar de mim, fale. A gente encontra lugar no mato. Ou, se quiser, vou dormir na sua barraca" (LEAL, 1971, p. 38-40). Prática comum, as mulheres trabalham limpando ou lavando durante o dia e prestam serviços sexuais durante a noite. Sendo aquele um novo morador do local, a mulher não vê problema em oferecer o serviço a ele. 
Figura 31 - 30 dias na ilusão do garimpo, Revista Realidade, nº 65, ago. 1971, p. 40-41

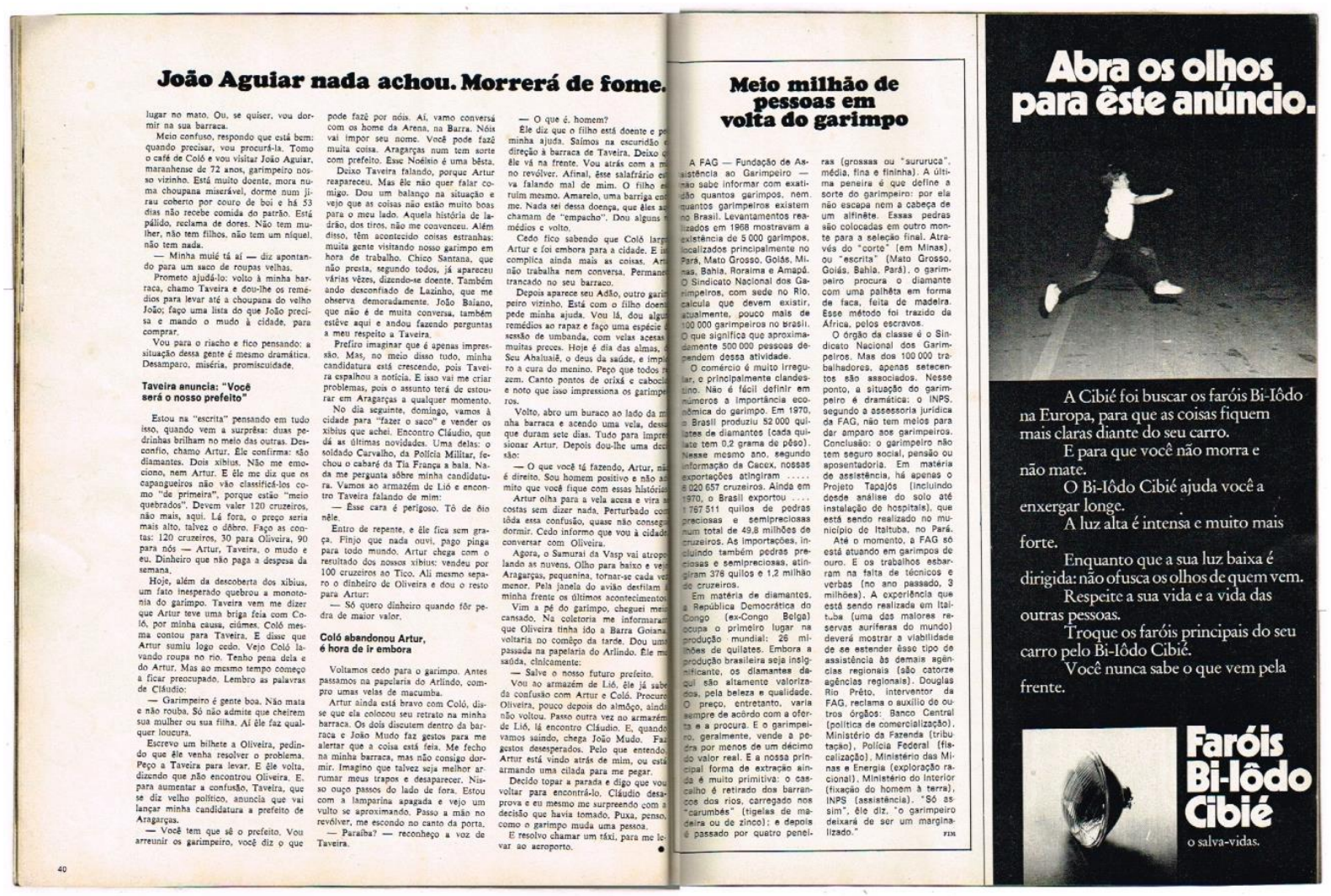

Fonte: Acervo do Grupo de Pesquisa Estudos Fotográficos (CNPq/UFCA)

A vida no garimpo é traiçoeira em mais de um sentido. Além do perigo iminente, criado pela névoa de violência que paira sobre aquele grupo, há também o perigo de não encontrar pedras preciosas e acabar na completa miséria. Um exemplo de homem morrendo na miséria absoluta depois de anos no garimpo é o de João Aguiar. Aos 71 anos de idade, aquele maranhense não recebe comida há 53 dias e reclama de fortes dores. Ele não possui absolutamente nada, nem família nem dinheiro. No título de página (Figura 31), a seguinte afirmação: “João Aguiar nada achou. Morrerá de fome” (LEAL, 1971, p. 40). Em uma atitude semelhante $^{48}$ àquela de outros repórteres de Realidade, José Leal destina alimentos e remédios para aquele garimpeiro.

Após estes acontecimentos, a reflexão do repórter-personagem: "Vou para o riacho e fico pensando: a situação dessa gente é mesmo dramática. Desamparo, miséria,

\footnotetext{
${ }^{48}$ Durante a cobertura da reportagem Uma vela contra o mar (1966), por exemplo, houve um envolvimento significativo entre a comunidade e os repórteres. De acordo com José Hamilton Ribeiro, Narciso Kalili e Luigi Mamprin "[...] ficaram tanto tempo lá, para se enturmarem com os pescadores, que, no fim, o Narciso já tava fazendo levantamento de recurso para resolver o problema da comunidade, já tava levando mulher de pescador para fazer consulta pra lá, fazer cirurgia pra cá... [...]” (RIBEIRO, 2013).
} 
promiscuidade" (LEAL, 1971, p. 40). O termo 'dramático' dá peso ao pensamento do jornalista. É uma vida desgraçada, repleta de acontecimentos comoventes e de cenas pungentes. Aquela parcela da população brasileira está na miséria, desamparada pelas ações do governo, dependendo de atos que podem trazer humilhação, porém uma humilhação socialmente aceita pela comunidade.

Em meio aos pensamentos que assolam o repórter-personagem, ele encontra duas pedrinhas que brilham mais que as outras. São dois xibius, diamantes pequenos. Não há emoção no garimpo a partir desta descoberta, posto que as pedras sejam muito pequenas. $\mathrm{O}$ dinheiro advindo daquelas pedras não será suficiente nem ao menos para o pagamento das dívidas da semana com alimentação. Os compradores não pagam valores justos, as taxas pagas aos donos dos garimpos são altas, não há como sair da miséria sem uma boa dose de sorte.

As brigas entre Coló e Artur, impulsionadas pela presença do repórter-garimpeiro, ganham dimensões preocupantes. Taveira traz a informação de que Artur sumiu em função de uma discussão. A percepção do narrador acerca da situação possui duas vertentes: por um lado, sente pena do casal; por outro, fica preocupado com a própria situação, uma vez que recorda um aviso de Cláudio, o qual disse que um garimpeiro faz qualquer loucura caso veja sua mulher ou filha ameaçada pela presença de um homem.

Paralelamente ao desentendimento com Artur, um acontecimento desconexo: Taveira anuncia uma suposta candidatura do repórter-personagem para prefeito de Aragarças. Devemos notar que aquela personagem tenta convencer os interlocutores a partir da seguinte argumentação: “- Você tem que sê o prefeito. Vou arreunir os garimpeiro, você diz o que pode fazê por nóis. Aí, vamo conversá com os home da Arena ${ }^{49}$, na Barra. Nóis vai impor seu nome. Você pode fazê muita coisa. Aragarças num tem sorte com prefeito. Esse Noélsio é uma besta" (LEAL, 1971, p. 40).

Provavelmente a proposta advém da fama que o repórter-personagem vai adquirindo junto aos garimpeiros. Aquele homem, chegado há pouco tempo, ajuda sempre que pode. Quer com medicamentos, quer com alimentos. Em alguns momentos, o mesmo é chamado em sua barraca, no período da noite, a fim de ir ver alguma outra pessoa que esteja doente.

Porém, paralelo a isso, o repórter-personagem começa a desconfiar de algumas das personagens que rondam o garimpo no qual trabalha. A ele não agrada as presenças de Chico

\footnotetext{
${ }^{49}$ Criada em 1965, a partir do Ato Institucional No 2, a Aliança Renovadora Nacional (ARENA) foi um partido alinhado com o regime militar, tendo como oposição consentida o Movimento Democrático Brasileiro (MDB).
} 
Santana, Lazinho e João Baiano. Imaginando ser um problema a suposta candidatura, o repórter-garimpeiro vai, no dia seguinte, à cidade. Planejando "fazer o saco", busca o armazém de Lió. Ao adentrar no estabelecimento, encontra Taveira informando o comerciante de que não confia no novo garimpeiro: “- Esse cara é perigoso. Tô de ôio nele” (LEAL, 1971, p. 40).

Os garimpeiros dão declarações contraditórias. Em determinado momento, Taveira acredita que o repórter-garimpeiro seria uma boa opção política para o local, momentos depois, declara desconfiar das intenções do mesmo. Desta forma, não há o estabelecimento de uma rede de confiança entre os moradores daquele grupo. As relações são dissimuladas.

E a personagem do repórter segue definindo suas feições. Após a chegada de Artur com os cem cruzeiros conseguidos com a venda dos diamantes, ele recusa-se a recebê-los. Profere a seguinte frase: “- Só quero dinheiro quando for pedra de maior valor” (LEAL, 1971, p. 40). Aos ouvidos dos garimpeiros, pode ter parecido um ato de soberba e excesso de autoconfiança.

A estratégia articulada pelo repórter-personagem para reaver a confiança dos garimpeiros atinge o nível espiritual. O garimpeiro decide adquirir velas de macumba. A situação entre Artur e Coló continua tensa. Eles brigam constantemente e João Mudo alerta o repórter-garimpeiro acerca da gravidade do problema. Ele cogita fugir, chega a noite e a insegurança aumenta. Ao ouvir passos ao redor da barraca, protege-se, procurando sua arma. É Taveira que o busca alegando que o filho esteja doente.

O repórter-personagem segue Taveira até a barraca, no escuro, inseguro e com a mão no revolver. A ação tinha traços que poderiam fazer com que aquele pedido fosse, na verdade, uma emboscada, mas a criança está doente. Ele dá alguns remédios e volta para a própria barraca. No dia seguinte, penúltimo da jornada do repórter-garimpeiro, Coló abandona Artur. Após o colapso do relacionamento, Artur tranca-se na barraca. Não conversa e nem trabalha.

O filho de mais um dos garimpeiros está doente. Adão, então, pede a ajuda do repórter-garimpeiro:

Vou lá, dou alguns remédios ao rapaz e faço uma espécie de sessão de umbanda, com velas acesas e muitas preces. Hoje é dia das almas, de Seu Abaluaiê, o deus da saúde, e imploro a cura do menino. Peço que todos rezem. Canto pontos de orixá e caboclo e noto que isso impressiona os garimpeiros (LEAL, 1971, p. 40). 
O narrador admite que fez tudo para impressionar Artur: após a sessão de umbanda, dispõe algumas velas em torno da própria barraca. Em seguida, conversa com Artur e diz não admitir que aquelas histórias sejam criadas sobre ele, posto que seja uma pessoa 'positiva'. Artur não se impressiona e sai da presença do repórter-garimpeiro sem comentar a fala daquele. Atormentado com os últimos acontecimentos, o homem não consegue dormir.

No dia seguinte, o repórter-garimpeiro decide ir à cidade em busca de Oliveira. Os últimos acontecimentos são repassados pelo repórter já dentro do avião que o levará de volta a São Paulo. Após ir à cidade caminhando, relembra:

\footnotetext{
Vou ao armazém de Lió, ele já sabe da confusão com Artur e Coló. Procuro Oliveira, pouco depois do almoço, ainda não voltou. Passo outra vez no armazém de Lió, lá encontro Cláudio. E, quando vamos saindo, chega João Mudo. Faz gestos desesperados. Pelo que entendo, Artur está vindo atrás de mim, ou está armando uma cilada para me pegar.

Decido topar a parada e digo que vou voltar para encontrá-lo. Cláudio desaprova e eu mesmo me surpreendo com a decisão que havia tomado. Puxa, penso, como o garimpo muda uma pessoa.

E resolvo chamar um táxi, para me levar ao aeroporto (LEAL, 1971, p. 40, grifo nosso).
}

A emoção que envolve os últimos acontecimentos faz com que o repórter-personagem não mais se identifique com as características que possuía anteriormente. O garimpo modifica suas visões de mundo. Quando afrontado, sua reação agora é se defender, enfrentar. A personagem de Cláudio é aquela que traz o repórter à realidade, apontando para o perigo iminente. Mesmo sem ter conhecimento da real identidade do homem, a personagem e João Mudo o salvam do que poderia ser a décima morte da narrativa: a do próprio jornalista.

O ambiente é de miséria, insegurança, violência e medo constante. Ficar imerso em um local com tais características torna os cidadãos desconfiados, bem como não se pode ter confiança neles. Buscando uma forma de sair da miséria, quer honestamente, quer por meio de furtos e assassinatos, todos os que estão envoltos naquele ambiente comungam de algumas características: 1) não são comumente lembrados pelos demais brasileiros; 2) vivem de forma instável; 3) são sujeitos anônimos, sem nome ou sobrenome; e 4) não possuem outra possibilidade de futuro. 
A seguir, descrevemos de forma sistematizada o percurso realizado pelo repórterpersonagem ao longo da narrativa. A busca pela aceitação e pela vivência o levam a alguns pontos de virada na narrativa. O que tem início com uma chegada amistosa termina com uma fuga do ambiente inóspito e violento.

Figura 32 - Síntese do percurso narrativo do repórter-personagem

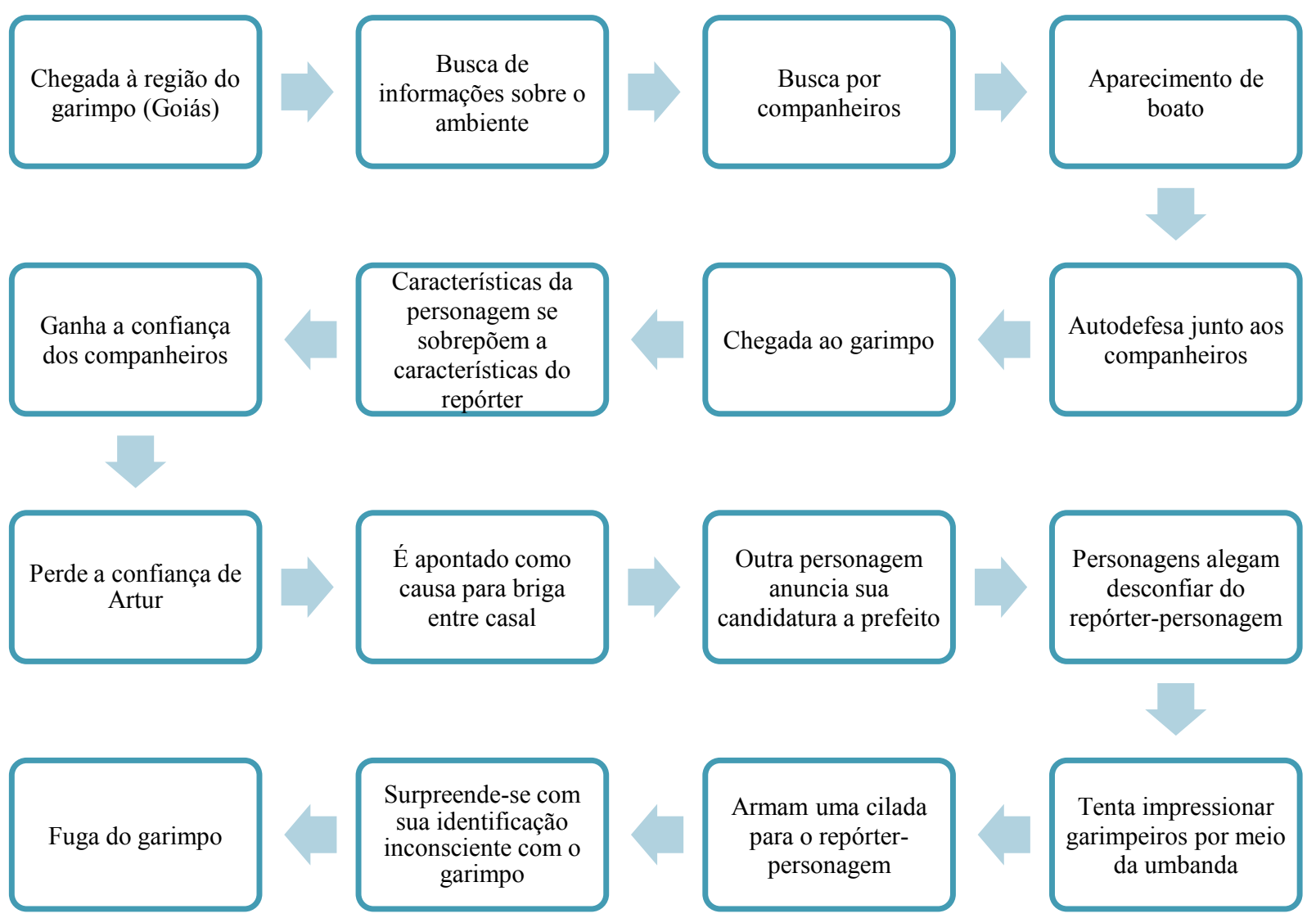

Fonte: os autores.

A narrativa de 30 dias na ilusão do garimpo é composta por diversas personagens. A maior parte deles aparece poucas vezes, muitos apenas uma. No garimpo, os homens lidam com muitas personagens ao mesmo tempo, porém de forma superficial. Em geral não se sabe muito acerca do passado dos garimpeiros que não sejam do mesmo garimpo, que não convivam diariamente.

As descrições que envolvem o tema morte assumem um papel primordial na narrativa aqui analisada. Tal elemento faz parte de diálogos, lembra os homens do perigo que os envolve e, sobretudo, aponta um elemento não-físico que ajuda a definir as ações dos homens, o caráter do garimpeiro e suas características psicológicas. Dado o contato cotidiano com a 
narrativa da morte, algumas personagens não se deixam mais surpreender pela maldade humana, assumem aquilo como o estado normal do ambiente e da vida em sociedade.

Este é o caso de Artur, logo na primeira cena, que sequer questiona sobre as circunstancias da morte de uma criança, posto que aquilo seja normal. Em contrapartida, aqueles que não lidam diretamente com o garimpo, como é o caso de Coló e Lió, surpreendem-se com as narrativas, buscam mais informações, expressam certa emoção em relação às vítimas.

No Quadro 3, elencamos quais foram as personagens mortas ao longo da narrativa, apontando os relatores e as circunstâncias dos eventos. Ao todo, foram relatadas nove situações que culminaram com o óbito de um garimpeiro ou de outro morador da região.

Quadro 3: Mortes relacionadas ao garimpo

\begin{tabular}{|c|c|c|c|}
\hline Personagem & Relator & Tipo de morte & Descrição da personagem \\
\hline Lurdinha & Lazinho & $\begin{array}{lll}\text { Estupro } & \text { seguido } & \text { de } \\
\text { assassinato } & & \end{array}$ & $\begin{array}{l}\text { Nove anos de idade; menina pura, } \\
\text { um anjo }\end{array}$ \\
\hline Mané do Cacau & Lazinho & Tocai seguida de assassinato & $\begin{array}{l}\text { Não pertencente ao grupo, não há } \\
\text { identificação junto aos } \\
\text { garimpeiros }\end{array}$ \\
\hline $\begin{array}{l}\text { Zequinha de } \\
\text { Floriano }\end{array}$ & $\begin{array}{l}\text { João } \\
\text { Mascarenhas } \\
\end{array}$ & $\begin{array}{ll}\text { Roubo seguido } & \text { de } \\
\text { assassinato (seis tiros) } & \\
\end{array}$ & \\
\hline $\begin{array}{l}\text { Filha de } \\
\text { Nenzinha }\end{array}$ & Joaquim & $\begin{array}{l}\text { Assassinada pela própria } \\
\text { mãe, ao nascer }\end{array}$ & Um anjinho \\
\hline $\begin{array}{l}\text { Betinho e } \\
\text { Ninito } \\
\text { (provavelmente) }\end{array}$ & Nonô & $\begin{array}{l}\text { Nove facadas em Betinho e } \\
\text { cinco em Ninito }\end{array}$ & $\begin{array}{lrr}\text { Aconteceu no } & \text { Garimpo } & \text { do } \\
\text { Deixado; crime cometido } & \text { por } \\
\text { garimpeiro desconhecido; } & \text { o } \\
\text { assassino sumiu } & \end{array}$ \\
\hline Jesuíno & $\begin{array}{l}\text { Dois } \\
\text { caboclos }\end{array}$ & $\begin{array}{l}\text { Morto a facadas dentro de } \\
\text { caminhão; o assassino levou } \\
\text { seus diamantes }\end{array}$ & $\begin{array}{l}\text { Ele era garimpeiro e foi morto a } \\
\text { caminho de outra cidade }\end{array}$ \\
\hline Maceió & Taveira & Quatro tiros no peito & Ninguém sabe quem foi \\
\hline Isabel & $\begin{array}{l}\text { Não } \\
\text { identificado }\end{array}$ & Tomando banho no rio & Estava grávida \\
\hline Mané & Lazinho & Assassinado por três ladrões & $\begin{array}{l}\text { Comprou pedra valiosa e } \\
\text { revendeu; estava indo para } \\
\text { Cuiabá com o dinheiro }\end{array}$ \\
\hline
\end{tabular}

Fonte: os autores. 


\section{CONSIDERAÇÕES FINAIS}

As narrativas significam e ressignificam o mundo através do uso da linguagem. Por meio de falas cotidianas, construímos o que entendemos como o mundo a nossa volta, bem como transmitimos aos nossos interlocutores a nossa interpretação acerca dos acontecimentos, vivenciados ou de conhecimento comum. Elas percorrem o globo. Somos, portanto, seres narrativos, somos, socialmente, fruto das nossas narrativas.

As reportagens, relatos mais aprofundados de acontecimentos, em detrimento das notícias diárias, implicam que os repórteres nelas envolvidos investiguem, apurem, entrevistem, chequem as informações e, só então, costurem suas narrativas, reconstruindo aquele fato em termos de linguagem: quer texto escrito, quer fotografias, ambos devem contar uma história real, composta por espaços, ambientes, personagens e, sobretudo, por uma intriga. Ao nos utilizarmos da Análise da Narrativa a fim de pensarmos tais textos, estamos nos aproximando de práticas culturais, pois a mesma lida com as narrativas essencialmente humanas (MOTTA, 2013).

Ao compor uma narrativa jornalística, o autor dispõe de elementos que pode conjugar em seu texto, criando possibilidades narrativas. Esses códigos a serem utilizados assemelhamse muito com aqueles empregados na literatura. Assim como as personagens ajudam a conduzir as narrativas ficcionais, contribuem, no texto jornalístico, para que o leitor se identifique com aquela narrativa, leia-a, interprete-a, comente-a. Do mesmo modo, ao se utilizar de um narrador que se permite fazer uma narrativa aprofundada, diferenciada, o autor cria um laço com o leitor: há um contrato narrativo naquele texto que permite que ele seja entendido como tendo bases estruturais no real, mesmo praticando o fluxo de consciência, por exemplo. A conjugação de um acontecimento factual com elementos narrativos gera uma narrativa que desperta o interesse do leitor, ao mesmo tempo em que expõe as informações advindas da apuração.

O ser real, dotado de interesse da mídia, se torna uma personagem da narrativa e, também, jornalística que, ao ser absorvida pelo leitor, pode se ver transformada em um misto 
de ser real com ser ficcional. A escolha das personagens realizada por determinado veículo, por sua vez, dá mostras da intencionalidade do mesmo. A seleção das características explicitadas pelo autor, se interpretada, aponta para o que ele se pretendia transmitir enquanto informação. Tais escolhas são explicitadas no texto por meio da linguagem, escrita ou imagética. No entanto, a linguagem está ligada à cultura por meio do que Hall (1997) conceitua enquanto representação. Desta forma, acreditamos ser importante destinarmos especial atenção aos significados que a linguagem pode assumir, considerando o contexto histórico no qual a reportagem é publicada.

Entendemos que a personagem detém relevada importância para o entendimento do texto jornalístico, desde a sua escolha enquanto elemento narrativo até a sua construção enquanto ser ficcional, existindo, conceitualmente, apenas no papel dos jornais ${ }^{50}$. A busca pela interpretação das intencionalidades ligadas à personagem permite ao pesquisador adentrar em aspectos que se referem aos contextos social, histórico e cultural no qual a narrativa foi concebida. A construção narrativa da personagem, portanto, aponta para a representação daquela enquanto integrante de uma cultura que a envolve.

As narrativas aqui analisadas emergem de um país fortemente dominado pelo autoritarismo. Os enredos tratados, no entanto, esquivam-se de abordar, diretamente, tais aspectos da realidade brasileira. Contudo, as consequências advindas da promulgação do Ato Institucional $\mathrm{N}^{0} 5$ estavam imbricadas nos repórteres. Intencional ou não intencionalmente, metáforas da perseguição política e da censura se expressam por meio dos efeitos de sentidos encontrados nos textos.

A produção dos efeitos de sentido, portanto, se dá por meio da seleção das falas, das personagens, dos espaços e, por fim, da construção do ambiente da reportagem. Como fica claro, cada uma destas escolhas tem uma finalidade em meio à trama. Por intermédio da narrativa, os narradores deixam transparecer aspectos da cultura que interligam aqueles indivíduos.

Ao narrar a perseguição e a fuga da personagem caranguejo em Povo Caranguejo, por exemplo, os narradores relatam cenas que podem ser entendidas como representações de momentos de tortura: o animal está encurralado pelas técnicas utilizadas pelos homens, ao passo que os brasileiros se viam encurralados por manobras políticas articuladas pelos militares. Em $O$ canavial esmaga o homem observamos mais uma vez metáforas que entrelaçam o interior do país e as ações governamentais: o homem está encerrado na prisão do

\footnotetext{
${ }^{50}$ Entendendo o termo 'papel' enquanto uma metáfora para todos os suportes midiáticos.
} 
canavial que o envolve. As canas são grades, o homem tem de submeter-se àquela situação em prol da manutenção da vida.

Vida esta que é construída por meio da representação do inferno. Todas as narrativas aqui apresentadas expressam uma brasilidade que preza pelo contato espiritual com o catolicismo. As personagens buscam na imagem de Deus a esperança para uma vida melhor. Se há um Deus que olhe por eles, diferentemente do governo, há a possibilidade de uma mudança. Os grupos sociais representados, no entanto, resignam-se aos problemas. A sociedade que tinha acesso aos benefícios advindos do Milagre Econômico, também. Estes eram, em parte, os leitores de Realidade. $\mathrm{O}$ apego ao aspecto espiritual da religião demonstra a possibilidade de outro Brasil, por conseguinte.

O canavial é uma prisão que tortura os homens dias e noite. O garimpo é um inferno onde a morte persegue cada um dos seus moradores. A vida do operário também assume ares de inferno: sem alimento, sem higiene, sem educação, sem saúde, as personagens sobrevivem, reclamam, mas não têm a possibilidade de redenção. $\mathrm{O}$ inferno enquanto significado envolve as personagens e dá o tom das narrativas: o sofrimento diário acompanha aqueles brasileiros e define, em partes, a cultura que os envolve. Não é uma miséria pontual, mas sim um reflexo da exploração do brasileiro pelo próprio brasileiro. Do homem pelo homem.

No entanto, a exploração não é, na maior parte das narrativas, explicitada. Sabemos que por trás do canavial está o dono do engenho, por trás da fábrica está o empresário, por trás da fazenda está o fazendeiro: mas estas personagens não são explicitadas. Há nas narrativas a aura da perseguição e da exploração, mas os responsáveis, em um primeiro grau, não possuem o status de personagens. Porém, falas e descrições constroem, indiretamente, o significado da exploração: o carro do dono do engenho o representa; o valor econômico dos bois expressam a existência do fazendeiro, sua ganância; o baixo valor do salário mínimo significa o grupo de empresários que explora os operários. Portanto, estas personagens são construídas de forma indireta, dando-nos a expressão de uma das características de Realidade: a habilidade para tratar de assuntos delicados de forma tangencial, porém não menos significativa. Em tempo de censura, a habilidade para tratar de assuntos caros à sociedade se apresenta enquanto uma virtude jornalística, cultural e social.

O perigo constante é outro significado que perpassa as narrativas. As personagens de Devagar com o boi enfrentam os perigos do caminho, desde doenças até a fuga dos animais. Em O canavial esmaga o homem os animais peçonhentos podem estar escondidos em qualquer touceira de cana, as personagens podem morrer em meio ao canavial. Povo 
Caranguejo possui uma personagem específica, a qual representa o medo: é a figura do Batatão. O exemplo máximo, no entanto, está presente em 30 dias na ilusão do garimpo: ali vemos a transcrição da cultura do medo. No momento em que o medo assume a função de um dos componentes do clima da narrativa, chegamos a uma representação extrema do Brasil. Naquela localidade, a violência, a morte e o medo guiam as atitudes das personagens.

Ora, o significado que fica das construções narrativas de Realidade remete a um Brasil de sujeitos explorados, física e psicologicamente. Enxergamos um país que fecha os olhos àqueles que são explorados e atormentados pelo clima de insegurança. Ao não deixar transparecer a existência de um governo que vá cuidar de seus cidadãos, deparamo-nos com uma imagem de uma nação que constrói suas bases identitárias sob a sombra do medo e da violência.

Outro aspecto que permeia as relações estabelecidas entre as personagens das narrativas e os detentores do poder é a exploração do trabalho. As personagens que conduzem a narrativa se apresentam enquanto alicerces para a construção de um Brasil economicamente emergente. Aqueles sujeitos têm sua mão de obra explorada, produzem riqueza, mas não usufruem a mesma. Gregório e o grupo de Peri Pereira assumem a representação do trabalhador escravo, atrelados a um escravocrata. Trabalham ganhando pouco ou quase nada, devem aos patrões, trocam a força física por comida. Os homens, para os detentores do poder, são máquinas que devem trabalhar em função do crescimento da riqueza, da qual não comungam.

Outro aspecto que discutimos diz respeito à construção dos enredos. Vivendo da pesca do caranguejo, toda a comunidade de Povo Caranguejo está estruturada em torno da luta travada com o animal, a miséria e a lama, a fim de sobreviverem naquele ambiente de pobreza. Os próprios moradores classificam a forma como vivem como uma 'vida matadeira'. Lembremos que

Narrar é uma técnica de enunciação dramática da realidade, de modo a envolver o ouvinte na estória narrada. Narrar não é, portanto, apenas contar ingenuamente uma história, é uma atitude argumentativa, um dispositivo de linguagem persuasivo, sedutor e envolvente. Narrar é uma atitude - quem narra quer produzir certos efeitos de sentido através da narração (MOTTA, 2013, p. 74).

Gregório também luta com o canavial. Gregório é um herói, ao passo que o canavial é o vilão da narrativa. Ambas as personagens, posto que entendemos a construção do canavial 
enquanto uma personagem (o mesmo possui características físicas e psicológicas, exige o esforço do homem e o subjuga), possuem armas e lutam: o homem busca o sustento físico, o canavial busca a dominação do espaço.

Neste sentido, a revista preza pela criação de personagens que vão além da pessoa física. Caranguejo e canavial são eleitos personagens. Assumem características humanas. Tomam um partido e lutam contra o homem. O brasileiro, portanto, é aquela personagem que luta diariamente pela sobrevivência, mesmo em um país que cresce economicamente. $\mathrm{O}$ brasileiro de Realidade tem de buscar na própria força a esperança de dias melhores. No entanto, a exploração não permite que ele se alimente corretamente, o que gera uma força deficiente. Estamos diante de uma situação cíclica, na qual o homem está ao centro explorado e, ao mesmo tempo lutando. Temos em mãos um brasileiro que busca forças sociais, em detrimento daquelas físicas.

Contudo, observamos, também, uma personagem que é facilmente iludida. Este é o caso dos peões de Devagar com o boi. Os homens assumem uma atividade impossível acreditando que serão capazes de cumpri-la. Adequam-se ao perfil esperado de um bom peão e são ludibriados. A recompensa pelo bom trabalho não existe. No entanto, apenas a experiência das personagens faz perceber quando estão sendo exploradas ou enganadas. Os peões ingênuos imaginam serem capazes de não perder as rezes. Joaquim, por sua vez, sabe ser impossível viver com um salário mínimo. Um salário de fome. Aprendeu que com aquele valor só tem o direito de morrer.

A experiência, no entanto, não é das características mais apreciadas por tais personagens. Os homens mais novos, ingênuos, acreditam serem capazes de vencer as adversidades. A criança de Povo Caranguejo brinca de pegar caranguejos. A criança de $O$ canavial esmaga o homem é levada a trabalhar no canavial para ajudar os pais. A criança de Quem é o homem no fundo do poço busca formas alternativas de conseguir dinheiro. As crianças, portanto, seguem os passos dos pais. Mas aquele não é o futuro que os pais almejam para os filhos. Eles veem na educação a saída para aquela situação de penúria e miséria.

Saúde, educação e trabalho são aspectos da vida daquelas comunidades que sobressaem. As personagens de um país distante não acessam os órgãos de saúde. No interior do Mato Grosso não há hospitais. Em Pernambuco as personagens sofrem de anemia. Contudo, o brasileiro sofre com o acesso à saúde: mesmo em São Paulo, cidade plenamente desenvolvida, as personagens de Quem é o homem no fundo do poço? nunca haviam ido ao médico. Tem-se, portanto, um brasileiro que está em estado de apatia frente aos problemas de 
saúde. Aquele brasileiro não tem possibilidades claras de sobrevivência, portanto, não percebe os demais problemas que o envolvem. Mesmo que haja a necessidade, acredita, por questões culturais, que aquela seja uma problemática menor. As personagens de Realidade julgam que a luta pela sobrevivência começa pela alimentação.

Aqui chegamos a um dos principais aspectos da narrativa de Realidade. $\mathrm{O}$ termo miséria é uma das palavras-chave de todos os enredos. Viver mergulhado na lama, por exemplo, pode ser tomado como uma metáfora onde podemos permutar o termo lama por miséria. As fotografias de Povo Caranguejo nos mostram um ser humano que faz parte do mangue, indissociável, que vive nele tanto quanto o caranguejo, que se torna uma estátua de lama em meio aos arbustos e raízes. A família de Joaquim vive miseravelmente. A família de Gregório vive na miséria. As pessoas comuns buscadas por Realidade a fim de conduzirem as narrativas fazem transparecer uma parcela do país que vive na miséria, que se submete à exploração por não possuírem outra opção de sobrevivência.

Além disso, o padrão familiar dos agrupamentos descritos por Realidade gira em torno da figura masculina. Os homens são os responsáveis financeiros das famílias, mas contam com a ajuda das mulheres. Os filhos, por sua vez, são o futuro da família, necessitam estudar, mas carregam ainda uma forte ligação com a manutenção da casa, tendo que trabalhar para ajudar os demais. As narrativas são escritas, portanto, em um momento de transição. Os mais velhos tomam consciência da necessidade do estudo para as crianças, no entanto o sujeito da infância está localizado entre duas problemáticas: a dificuldade de acesso à educação e as dificuldades financeiras do grupo social.

A construção de significados de Realidade advém, conforme tratamos, da vivência dos repórteres. O mergulho, portanto, se dá respeitando a cultura do outro. São brasileiros buscando informações acerca de brasileiros. Ambos se constroem por meio das narrativas. Os jornalistas da revista despem-se, parcialmente, de suas identidades e mergulham rumo aos significados das escolhas culturais realizadas pelas personagens. Quando José Leal vai ao garimpo, passa de repórter a personagem da narrativa. O homem não mais é aquele repórter que deixa a redação de Realidade. Ele se veste de garimpeiro e vai ao garimpo. Ele constrói uma personagem e vivencia aquela experiência enquanto sujeito. As duas identidades, a do repórter e a do garimpeiro, começam a interagir. Conforme passam os dias, a identidade do garimpeiro supera a do repórter. O garimpo, segundo o narrador, muda o homem.

A presença do jornalista enquanto personagem ainda pode ser sentida em Quem é o homem no fundo do poço?. As incursões da personagem pelo texto servem para guiar a 
narrativa. Quando o narrador sente a necessidade que alguma informação seja proferida pela personagem principal, ele se coloca na narrativa, questionando a Joaquim. A personagem, neste sentido, reconduz o fio narrativo. É a expressão do repórter enquanto um ser que pergunta $^{51}$. É o jornalismo retratando o próprio jornalista, dando a ele a função de conduzir a narrativa. No entanto, a narrativa a qual temos acesso se dá especialmente em função das perguntas realizadas pelo jornalista enquanto em campo. A narrativa que lemos é uma expressão da apuração do repórter.

A partir do conteúdo explicitado por Realidade, podemos considerar a riqueza, em termos narrativos, que é a construção da reportagem nos moldes trilhados pela revista. Os repórteres respeitam a cultura na qual imergem, colhem as impressões das pessoas que ali habitam e as reconstrói. É no momento de reconstrução que o narrador nos permite entrever os aspectos da cultura brasileira. Por conseguinte, é por meio do valor dado às personagens que encontramos os aspectos da brasilidade, os elementos identitários do 'ser brasileiro', construídos nas páginas de uma revista de reportagens, com circulação expressiva pelo Brasil.

Tais narrativas só se tornam possíveis, com tal nível de descrição e interação com o meio sociocultural, a partir da experiência da qual trata Benjamin (1987): a vivência, fonte dos narradores dos mitos, é a mesma fonte da qual bebem os narradores de Realidade. Experiência e narrativa retroalimentam-se. Os significados que estampam as páginas da revista se servem de uma forma diferenciada de vivência, na qual o repórter permite à personagem contar sua estória. O narrador conduz, mas a experiência que advém do texto parte das personagens. O jornalista-narrador, portanto, escuta, reformula e escreve aquilo que a experiência lhe permite observar.

A narrativa é permeada por passagens nas quais podemos traçar paralelos entre o momento histórico vivido pelo país e a situação da comunidade, demonstrando a capacidade da narrativa de conter aspectos mais amplos que a história em si. É o plano da metanarrativa que nos faz perceber a interação do contexto com a produção narrativa. No entanto, tais metáforas só podem ser lidas e compreendidas desde que os indivíduos compartilhem códigos culturais, que vão desde a linguagem até o contexto político. Vivia-se sob a égide de uma ditadura e do autoritarismo. As narrativas apontam para um país distante, que também dá lugar a ações características de tais governos. Realidade entendia que as metáforas, os paralelos, poderiam ser interpretadas por seus leitores.

\footnotetext{
${ }^{51}$ Audálio Dantas assim os define, no livro Repórteres, baseado na frase proferida por Acácio Ramos, repórter da Folha de S.Paulo. [DANTAS, Audálio (Org.). Repórteres. São Paulo: Editora SENAC, 1998]
} 
Podemos perceber, portanto, a intencionalidade dos jornalistas-narradores em mostrarem um país distante e desconhecido, redescobrindo-o e aos brasileiros por meio de pautas e, sobretudo, de uma liberdade estética diferenciada daquela encontrada nos demais meios de comunicação da época. Ao dar vida, ao humanizar as personagens de um Brasil não explorado pela mídia, a revista vai construindo elementos que assumem, socialmente, a função de edificar a identidade do brasileiro naquelas décadas. Ao gravar em suas páginas aspectos não tratados, por outros veículos, da cultura brasileira, dá-nos a possibilidade de, hoje, mais de quarenta anos após as construções narrativas, acessarmos aspectos característicos daquele momento histórico. Mais que isso, ao criar narrativas, Realidade nos possibilita reconstruir, em termos de sentidos, um país em pleno regime militar, autoritarista.

De acordo com Motta (2013), temos de buscar na enunciação as formas por meio das quais os interlocutores criam sentido em meio às performances linguísticas. Em Povo Caranguejo, narrativa peculiarmente traçada, dando voz ao homem e ao animal, o narrador permite à narrativa mostrar-se em um formato diferenciado, que informa aos leitores, comtemplando os dados coletados no mangue e transpondo para o discurso elementos construtores e caracterizadores da comunidade, os quais nos permitem entender parte da relação que os pescadores estabelecem com o caranguejo e, numa segunda instância, com o ambiente de pobreza e miséria que o envolve.

Porém, a opção por uma narrativa diferenciada não se dá apenas no caso de Povo Caranguejo. Podemos perceber que todos os casos aqui elencados optaram por um caminho diferenciado, rumo à significação. As opções por recortes temporais são distintas, podendo ir desde a descrição de um dia de trabalho, uma jornada completa ou um período de vivência. A escolha da parcela temporal influencia na narrativa. As escolhas de componentes da narrativa são fundamentais à construção da mesma. Os dêiticos, as personagens, as intrigas e mesmo a construção física das passagens vão além dos efeitos de real. Um exemplo pode ser percebido na relação que os homens possuem com as armas em Devagar com o boi. A arma, içada de seu contexto, tem a função de simbolizar o poder daquele que a detém. Contudo, para os peões elas possuem outras funções, indo desde a construção das personagens até a companhia: a arma assume, por meio da construção narrativa, o papel de amiga, confidente, daqueles seres solitários.

Percebemos na conjugação da análise do texto em si com a projeção do mesmo em seu contexto histórico uma forma de entendermos como a revista se posicionou frente ao governo 
ditatorial e, sobretudo, ao propagandeado crescimento, que não atendia a todos os brasileiros de forma igualitária.

Assim, vislumbramos no boiadeiro, no trabalhador de engenho, no pescador de caranguejo, no operário e no garimpeiro a possibilidade de entendermos como se deu a reconstrução por parte dos repórteres, e desta publicação em especial, daqueles ambientes culturais, dos vínculos ali estruturados e, sobretudo, da relação que aquelas comunidades mantinham com o Brasil da época, em pleno desenvolvimento econômico. 


\section{REFERÊNCIAS BIBLIOGRÁFICAS}

A REVISTA no Brasil. São Paulo: Editora Abril, 2000.

ALMEIDA, Ligia Martins de. Gente simples, gente boa - Gente brasileira. In: RIBEIRO, José Hamilton; MARÃO, José Carlos. Realidade Re-vista. Santos: Realejo Edições, 2010. p. 307309.

ALMEIDA, Maria Fernanda Lopes. Veja sob censura: 1968-1976. São Paulo: Jaboticaba, 2009.

ALVES, Valéria Aparecida. Para não dizer que não falei dos festivais. Música e política na década de 60. São Paulo, 2001. Dissertação (Mestrado em História), Faculdade de Ciências Sociais, Pontifícia Universidade Católica de São Paulo.

ANDRADE, Jorge. O canavial esmaga o homem. Realidade, São Paulo, n. 46, p. 32-39, jan. 1970.

AZEVEDO, Carlos. Cicatriz de Reportagem: 13 histórias que fizeram um repórter. São Paulo: Editora Papagaio, 2007.

BAENINGER, Rosana. Fases e faces da migração em São Paulo. Campinas: Unicamp, 2012.

BAPTISTA, Íria Catarina Queiróz; ABREU, Karen Cristina Kraemer. A História das Revistas no Brasil: um olhar sobre o segmento mercando editorial. 2010. Disponível em: $<$ http://www.bocc.ubi.pt >. Acesso em: 16 abr. 2011.

BARTHES, Roland. O efeito de real. In: BARTHES, Roland et al. Literatura e Semiologia. Petrópolis: Editora Vozes, 1972.

. Introdução à Análise Estrutural da Narrativa. In: BARTHES, Roland et al. Análise Estrutural da Narrativa. Petrópolis: Editora Vozes Limitada, 1973. 1984.

A Câmara Clara: Nota sobre a fotografia. 2. ed. Rio de janeiro: Nova Fronteira,

Mitologias. 7. ed. Rio de Janeiro: DIFEL, 2013.

BARZOTTO, Valdir Heitor. Leituras de Revistas Periódicas: forma, texto e discurso, um estudo sobre a revista Realidade $(1966$ - 1976). Campinas, 1998. Tese (Doutorado em 
Linguística), Instituto de Estudos da Linguagem - Universidade de Campinas.

BENJAMIN, Walter. O narrador: Considerações sobre a obra de Nikolai Leskov. In: Magia e Técnica, arte e política: Ensaios sobre literatura e história da cultura. Trad. Sergio Paulo Rouanet. São Paulo: Editora Brasiliense, 1987.

BISILLIAT, Maureen. Maureen Bisilliat: depoimento [16 abr. 2013]. Entrevistadores: Carla Adelina Craveiro Silva e Marcelo Eduardo Leite. São Paulo SP, 2013. Entrevista concedida ao Projeto Realidade: o fotojornalismo (autoral) de uma revista.

BOTELHO, Rosana Ulhôa. Sob o Signo do Perigo: o Estatuto do Jovem no Século da Criança e do Adolescente. Brasília, 2000. Tese (Doutorado em História), Universidade de Brasília.

BRAIT, Beth. A personagem. São Paulo: Editora Ática, 1998.

CAMPOS, Gil. "Jornalista tem que saber ler". Observatório da Imprensa, 24 abr. 2007. Ed. 430. Disponível em: <http://www.observatoriodaimprensa.com.br/news/view/jornalista-temque-saber-ler>. Acesso em: 03 jul. 2013.

CHIODI, Amâncio. Amâncio Chiodi: depoimento [22 maio 2013]. Entrevistadores: Leylianne Alves Vieira e Marcelo Eduardo Leite. São Paulo, 2013. Entrevista concedida ao Projeto Realidade: o fotojornalismo (autoral) de uma revista.

CORRÊA, Thomaz Souto. A era das revistas de consumo. In: LUCA, Tania Regina de; MARTINS, Ana Luiza (Orgs.). História da Imprensa no Brasil. São Paulo: Contexto, 2008, p. 207-232.

COSTA, Helouisa; BURGI, Sérgio (Orgs.). As origens do fotojornalismo no Brasil: um olhar sobre O Cruzeiro. São Paulo: Instituto Moreira Salles, 2012.

CUNHA, Maria Jandyra Cavalcanti. A narrativa jornalística em testemunho. In: MOTA, Célia Ladeira; MOTTA, Luiz Gonzaga; CUNHA, Maria Jandyra. (Orgs.) Narrativas Midiáticas. Florianópolis: Insular, 2012.

DANTAS, Audálio. Povo Caranguejo. Realidade, São Paulo, n. 48, p. 102-112, mar. 1970. 1971. Quem é o homem no fundo do poço? Realidade, São Paulo, n. 58, p. 08-15, jan.

Tempo de Reportagem. São Paulo: Leya, 2012.

Audálio Dantas: depoimento [15 abr. 2013]. Entrevistadores: Carla Adelina Craveiro Silva e Marcelo Eduardo Leite. São Paulo SP, 2013. Entrevista concedida ao Projeto Realidade: o fotojornalismo (autoral) de uma revista.

DEPOIMENTO: Audálio Dantas. Disponível em: <http://realidaderevista.blogspot.com.br/2012/04/depoimento-audalio-dantas.html>. Acesso em: 03 jul. 2013. 
DUCROT, Oswald; TODOROV, Tzvetan. Dicionário enciclopédico das ciências da linguagem. 3.ed. São Paulo: Editora Perspectiva, 2001.

EARP, Fábio Sá; PRADO, Luiz Carlos. O "milagre" brasileiro: crescimento acelerado, integração internacional e distribuição de renda (1967-1973). In: FERREIRA, Jorge Luiz; DELGADO, Lucilia de Almeida Neves (Orgs.). O tempo da ditadura: regime militar e movimentos sociais em fins do século XX. 2. ed. (O Brasil Republicano, v. 4). Rio de Janeiro: Civilização Brasileira, 2007.

ECO, Umberto. James Bond: Uma Combinatória Narrativa. In: BARTHES, Roland et al. Análise Estrutural da Narrativa. Petrópolis: Editora Vozes Limitada, 1973.

EDITORIAL. Realidade. São Paulo. Editora Abril,1966.

FARO, José Salvador. Revista REALIDADE - 1966-1968 - Tempo de reportagem na imprensa brasileira. Ulbra/AGE, 1999.

FERNANDES, Terezinha Tagé Dias. Jorge Andrade, repórter Asmodeu: leitura do discurso jornalístico de autor na revista "Realidade". São Paulo, 1988. Tese (Doutorado), Escola de Comunicação e Artes, Universidade de São Paulo.

FOLHA Online. Sérgio de Souza, editor da revista "Caros Amigos", morre em São Paulo. Disponível em: <http://www1.folha.uol.com.br/folha/ilustrada/ult90u385660.shtml>. Acesso em 03 jul. 2013.

FOUCAULT, Michel. A ordem do discurso. São Paulo: Edições Loyola, 1996.

FRANÇA, Vera Regina Veiga. O acontecimento para além do acontecimento: uma ferramenta heurística. In: FRANÇA, Vera Regina Veiga; OLIVEIRA, Luciana de. (Orgs.). Acontecimento: Reverberações. Belo Horizonte: Autêntica Editora, 2012. p. 39-51.

GADAMER, Hans Georg. Verdade e método I: traços fundamentais de uma hermenêutica filosófica. 10. ed. Petrópolis: Vozes, 2008.

GANCHO, Cândida Vilares. Como analisar narrativas. São Paulo: Editora Ática, 1991.

GARCIA, Bruno. Tzvetan Todorov: Só a ficção salva. 2012. Disponível em: $<$ http://www.revistadehistoria.com.br/secao/entrevista/tzvetan-todorov>. Acesso em 24 jun. 2014.

GOVERNO Federal. Atos Institucionais. Portal da Legislação. Disponível em: $<\mathrm{http}$ ://www4.planalto.gov.br/legislacao/legislacao-historica/atos-institucionais $>$. Acesso em: 01 jul. 2013.

HABERT, Nadine. A década de 70: Apogeu e crise da ditadura militar brasileira. 3. ed. São Paulo: Ática, 1996.

HALL, Stuart. Representation: Cultural Representations and Signifying Practices. Londres: Sage, 1997. 
A identidade cultural na pós-modernidade. Trad. Tomaz Tadeu da Silva, Guaracira Lopes Louro. 11.ed. Rio de Janeiro: SP\&A, 2006.

HEMEROTECA Digital Brasileira. Revista Realidade. Disponível em: $<$ http://memoria.bn.br/DOCREADER/DOCREADER.ASPX?BIB=213659>. Acesso em: 03 out. 2014.

HUSSERL, Edmund. Investigações lógicas: sexta investigação. São Paulo: Editora Nova Cultural Ltda., 2005.

IRMÃOS Coragem $\quad-\quad 1^{\mathrm{a}} \quad$ versão. Disponível em: $<$ http://memoriaglobo.globo.com/programas/entretenimento/novelas/irmaos-coragem-1versao/trama-principal.htm>. Acesso em: 02 jul. 2015.

KELLNER, Douglas. A cultura da mídia: estudos culturais: identidade e política entre o moderno e o pós-moderno. São Paulo: EDUSP, 2001.

KOBRÉ, Kenneth. Fotojornalismo: uma abordagem profissional. São Paulo: Campus/Elsevier, 2011.

KUCINSKY, Bernardo. Jornalistas e Revolucionários. São Paulo: Editora Página Aberta Ltda., 1991.

LAURENZA, Ana Maria de Abreu. Batalhas em Letras de Forma: Chatô, Wainer e Lacerda. In: LUCA, Tania Regina de; MARTINS, Ana Luiza (Orgs.). História da Imprensa no Brasil. São Paulo: Contexto, 2008, p. 179-205.

LEAL, José. 30 dias na ilusão do garimpo, Realidade, São Paulo, n. 65, p. 28-41, ago. 1971.

LEISTER FILHO, Adalberto. A realidade em revista, a revista Realidade. A memória dos jornalistas de uma publicação revolucionária. Pesquisa de Iniciação Científica financiada pela Fundação de Amparo à Pesquisa do Estado de São Paulo (Fapesp) e concluída em 1997.

LIMA, Edvaldo Pereira. O Livro-reportagem como extensão do jornalismo impresso: realidade e potencialidade. São Paulo, 1990. Tese (Doutorado), Escola de Comunicação e Artes, Universidade de São Paulo.

. Páginas Ampliadas: o livro-reportagem como extensão do jornalismo e da literatura. 4 ed. Barueri: Manole, 2009.

MAGNO, Ana Beatriz. A agonia da reportagem: das grandes aventuras da imprensa brasileira à crise do mais fascinante dos gêneros jornalísticos: uma análise das matérias vencedoras do Prêmio Esso. 2006. 133 f. Dissertação (Mestrado em Comunicação) Universidade de Brasília.

MARÃO, José Carlos. Vida, paixão e morte de Nossa Senhora Realidade. In: RIBEIRO, José Hamilton; MARÃO, José Carlos. Realidade Re-vista. Santos: Realejo Edições, 2010. p. 21 37. 
Ele desafiou a vida e jornalismo. Observatório da Imprensa, 2008. Disponível em: $<$ http://www.observatoriodaimprensa.com.br/news/view/ele-desafiou-a-vida-e-o-jornalismo $>$. Acesso em: 12 set. 2013.

MELO, Chico Homem de (Org.). O design gráfico brasileiro: anos 60. São Paulo: Cosac Naify, 2006.

MESQUITA, M. O Quarto Equívoco: O poder dos media na sociedade contemporânea. Coimbra: Minerva Coimbra, 2004.

MORAES, Letícia Nunes de. Cartas ao Editor: leituras da revista Realidade (1966-1968). São Paulo: Alameda, 2007.

MORAES, Vaniucha de. Realidade (Re)vista: O Papel do Intelectual na Concepção de um Projeto Revolucionário. 2010. Dissertação (Mestrado em Jornalismo) - Universidade Federal de Santa Catarina, Florianópolis, 2010.

MOTA, Célia Maria Ladeira dos Santos. O gesto e a palavra: representações sobre cidadania no telejornal. In: VIZEU, Alfredo; PORCELLO, Flávio; MOTA, Célia Ladeira. (Orgs.). Telejornalismo, a nova praça pública. Florianópolis, Editora Insular, 2006.

Representações da identidade nacional na notícia da TV.2008. 331 p. Tese (Doutorado em Comunicação) - Universidade de Brasília, Faculdade de Comunicação, Brasília, 2008.

MOTA, Celia Ladeira; MOTTA, Luiz Gonzaga; CUNHA, Maria Jandyra. (Orgs.) Narrativas Midiáticas. Florianópolis: Insular, 2012.

MOTA, Célia Maria Ladeira. Jornalismo: discurso, narrativa e cultura. In: PEREIRA, Fábio Henrique; MOURA, Dione Oliveira; ADGHIRNI, Zélia Leal (Orgs.). Jornalismo e sociedade: teorias e metodologias. Florianópolis: Insular, 2002.

MOTA, Celia Maria Ladeira; ALMEIDA, Paulo Henrique Soares de. Narrativas da identidade brasileira: Jornalismo e redes sociais. Brasília: Editora Kiron, 2015.

MOTTA, Luiz Gonzaga. Narratologia: teoria e análise da narrativa jornalística. Brasília: Casa das Musas, 2005.

Análise Crítica da Narrativa. Brasília: Editora Universidade de Brasília, 2013.

MOULliAUD, Maurice; PORTO, Sérgio Dayrell (Org.). O Jornal: da forma ao sentido. 3. ed. Brasília: Editora Universidade de Brasília, 2012.

MUNTEAL, Oswaldo; GRANDI, Larissa. A imprensa na história do Brasil: fotojornalismo no século XX. Rio de Janeiro: Ed. PUC-Rio/Desiderata, 2005.

NASCIMENTO, Patrícia Ceolin. Jornalismo em revistas no Brasil: um estudo das construções discursivas em Veja e Manchete. São Paulo: Annablume, 2002. 
NEWHALL, Beaumont. Historia de la Fotografía. 2 ed. Barcelona: Editorial Gustavo Gilli, 2006.

NORONHA, Eduardo; ERVOLINO, Ivan. O poder sindical na ditadura e na transição política brasileira. In: NAPOLITANO, Carlo José et al (Orgs). O Golpe de 1964 e a Ditadura Militar em Perspectiva. São Paulo: Cultura Acadêmica, 2014.

NUNES, Benedito. O tempo na narrativa. São Paulo: Editora Ática, 1988.

PANZER, Mary. Introducción. In: Las cosas tal como son: el fotoperiodismo en contexto desde 1955. World Press Photo. Art Blume: Barcelona, 2006, p. 08-33.

PEREIRA, Raimundo. Raimundo Pereira: depoimento [28 jun. 2013]. Entrevistador: Marcelo Eduardo Leite. São Paulo SP, 2013. Entrevista concedida ao Projeto Realidade: o fotojornalismo (autoral) de uma revista.

PILAGALLO, Oscar. A história do Brasil no século 20: (1960-1980). São Paulo: Publifolha, 2004.

PROPP, Vladimir; MELETINSKII, E. M. Morphologie du conte: suivi de Les transformations des contes merveilleux et de L'estude structurale et typologique du conte. Paris: Seuil, 1970.

QUÉRÉ, Louis. Entre facto e sentido: a dualidade do acontecimento. Trajectos: Revista de Comunicação, Cultura e Educação, Lisboa, n. 6, p. 59-75, 2005.

REIS, Carlos Antonio Alves dos; LOPES, Ana Cristina M. Dicionário de Teoria da Narrativa. São Paulo: Ática, 1988.

RESENDE, Fernando. O olhar às avessas: a lógica do texto jornalístico. Tese (Doutorado) Universidade de São Paulo, Escola de Comunicação e Artes, São Paulo, 2002.

RIBEIRO, José Hamilton. A experiência do preconceito. In: RIBEIRO, José Hamilton; MARÃO, José Carlos. Realidade Re-vista. Santos: Realejo Edições, 2010. p. 201-205.

Eu sou João, homem sem leitura. In: RIBEIRO, José Hamilton; MARÃO, José Carlos. Realidade Re-vista. Santos: Realejo Edições, 2010. p. 310-318.

. José Hamilton Ribeiro: depoimento [14 abr. 2013]. Entrevistadores: Carla Adelina Craveiro Silva e Marcelo Eduardo Leite. São Paulo SP, 2013. Entrevista concedida ao Projeto Realidade: o fotojornalismo (autoral) de uma revista.

RIDENDI, Marcelo. Em Busca do Povo Brasileiro. Rio de Janeiro, Record, 2000.

ROSA, Márcia Eliane. Os sentidos pluralistas do cotidiano da cultura nas reportagens da revista Realidade nos anos de 1966 a 1968. São Paulo, 2006. Tese (Doutorado), Escola de Comunicação e Artes, Universidade de São Paulo. 
SAUSSURE, Ferdinand de et al. Textos selecionados. 2.ed. Col. Os Pensadores. São Paulo: Abril Cultural, 1978.

SCALZO, Marília. Jornalismo de revista. 3 ed. São Paulo: Contexto, 2008.

SEVERIANO, Mylton. Realidade: história da revista que virou lenda. Florianópolis: Insular, 2013.

SILVA, Dacio Renault da. Jornalismo e história: o jornalista como historiador do presente. 2011. 181 f. Tese (Doutorado em Comunicação) - Universidade de Brasília, Faculdade de Comunicação, Programa de Pós-Graduação em Comunicação, 2011.

SIMONARD, Pedro. A Geração do Cinema Novo: para uma Antropologia do Cinema. Rio de Janeiro: Mauad, 2006.

SINOPSE do Censo Demográfico 2010 Brasil. IBGE. Disponível em: $<$ http://www.censo2010.ibge.gov.br/sinopse/index.php?dados $=4 \& u f=00>$. Acesso em: 26 set. 2013.

SOARES, Dirceu. Devagar com o Boi. Realidade, São Paulo, n. 37, p. 60-69, abr. 1969.

SODRÉ, Muniz. A narração do fato: notas para uma teoria do acontecimento. Petrópolis: Vozes, 2009.

SOLARI, Jean. Jean Solari: depoimento [25 jun. 2013]. Entrevistador: Marcelo Eduardo Leite. Saquarema RJ, 2013. Entrevista concedida ao Projeto Realidade: o fotojornalismo (autoral) de uma revista.

STEVENS, Cristina Maria Teixeira. IMAGI-NAÇÕES. Literatura e Identidades Migrantes. In: CUNHA, Maria Jandyra et al. Migração e identidade: olhares sobre o tema. São Paulo: Centauro, 2007.

VILAS BOAS, Sérgio. O estilo magazine: o texto em revista. São Paulo: Summus, 1996.

WILliAMS, Raymond. Cultura e Sociedade. São Paulo: Companhia Editora Nacional, 1969.

WOLFE, Tom. Radical Chique e o novo Jornalismo. Trad. José Rubens Siqueira. Pós-fácil Joaquim Ferreira dos Santos. São Paulo: Companhia da Letras, 2005.

1957: PRÊMIO PRINCIPAL. Disponível em:

$<$ http://www.premioexxonmobil.com.br/site/premio_principal/index.aspx?year=1957>.

Acesso em: 04 jul. 2015. 